MPR

NR. 22021

Elin Angelo, Jens Knigge, Morten Sæther \& Wenche Waagen (Eds.)

\title{
Higher Education
}

as Context for Music

Pedagogy Research

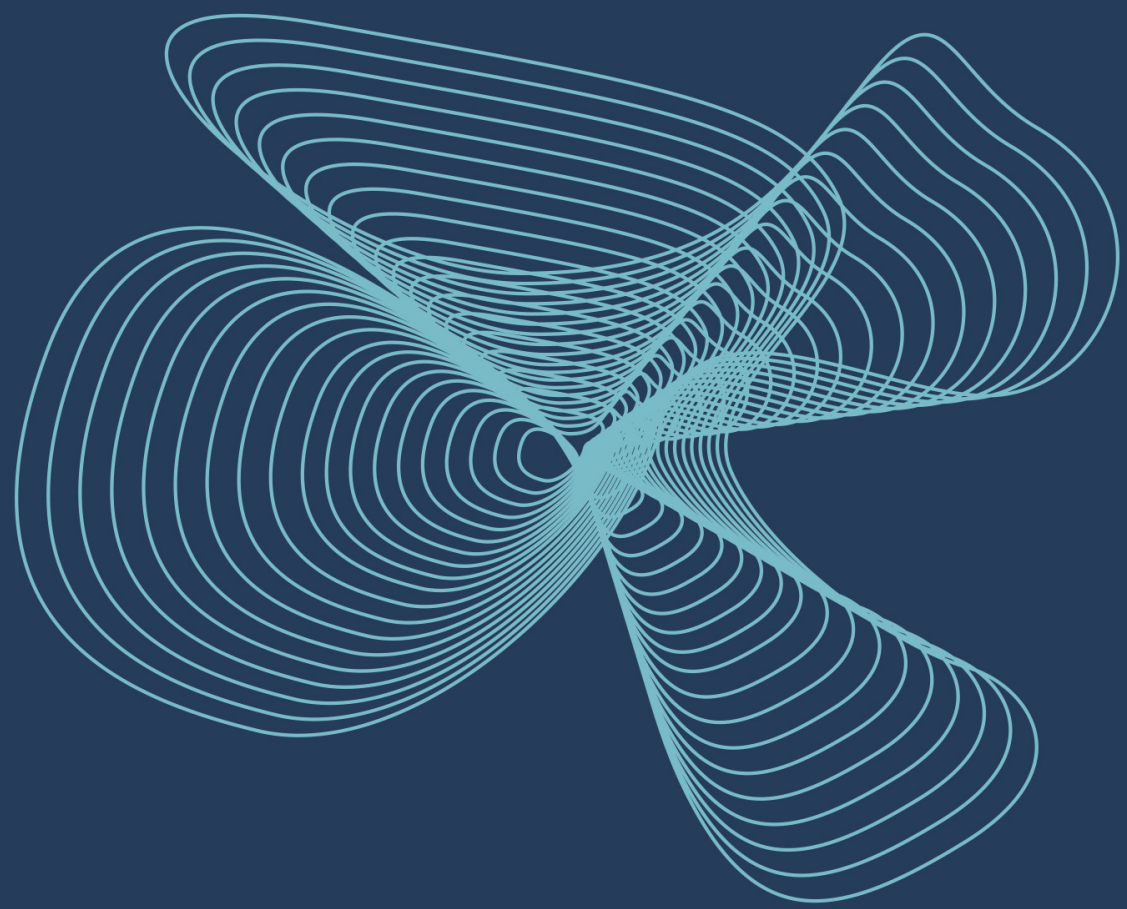

\section{NOASP}


Higher Education as Context for Music Pedagogy Research 

Elin Angelo, Jens Knigge, Morten Sæther \&

Wenche Waagen (Eds.)

\section{Higher Education as Context for Music \\ Pedagogy Research}


(C) 2021 Elin Angelo, Anne Haugland Balsnes, Anders Dalane, Fritz Flåmo Eidsvaag, David Scott Hamnes, Anne-Lise Heide, Sunniva Skjøstad Hovde, Dag Jansson, Runa Hestad Jenssen, Jens Knigge, Carina Borgström Källén, Monica Lindgren, Robin Rolfhamre, Ragnhild Sandberg-Jurström, Morten Sæther, Jan Ketil Torgersen, Ben Toscher, Roy A. Waade, Wenche Waagen og Olle Zandén.

This work is protected under the provisions of the Norwegian Copyright Act (Act No. 2 of May 12, 1961, relating to Copyright in Literary, Scientific and Artistic Works) and published Open Access under the terms of a Creative Commons AttributionNonCommercial-NoDerivatives 4.o International (CC BY-NC-ND 4.o) License (https:// creativecommons.org/licenses/by-nc-nd/4.o/). This license allows third parties to copy and redistribute the material in any medium or format for non-commercial purposes only. If you remix, transform, or build upon the material, you may not distribute the modified material.

Third parties are prohibited from applying legal terms or technological measures that restrict others from doing anything permitted under the terms of the license. Note that the license may not provide all of the permissions necessary for an intended reuse; other rights, for example publicity, privacy, or moral rights, may limit third party use of the material.

This book has been made possible with support from Karlstad University, Nord University, Norwegian University of Science and Technology, Queen Mauds University College of Early Childhood Education, University of Agder and University of Gothenburg.

ISSN: $2703-7843$

ISBN PDF: 978-82-02-69697-9

ISBN EPUB: 978-82-02-71179-5

ISBN HTML: 978-82-02-71180-1

ISBN XML: 978-82-02-71181-8

ISBN Print Edition: 978-82-02-70632-6

DOI: https://doi.org/10.23865/noasp.119

This is a peer-reviewed anthology.

Cover Design: Cappelen Damm AS

Cappelen Damm Akademisk/NOASP

www.noasp.no

noasp@cappelendamm.no 


\section{Contents}

Higher Education as Context for Music Pedagogy Research

Elin Angelo, Jens Knigge, Morten Sæther \& Wenche Waagen

Chapter 1 A Mozart Concert or Three Simple Chords? Limits for Approval in Admission Tests for Swedish Specialist Music Teacher Education 19

Ragnhild Sandberg-Jurström, Monica Lindgren \& Olle Zandén

Chapter 2 Vurderingskriterier i utøvende musikk - et verktøy for pålitelig vurdering av studentenes bachelorkonsert? 41

Wenche Waagen

Chapter 3 The Craftsmanship that Disappeared? Investigating the Role of the Principal Instrument in Music Teacher Education Programs 65

Fritz Flåmo Eidsvaag \& Elin Angelo

Chapter 4 Can We Buy Virtue? Implications from State University Funding On Musical Instrument Performance Teacher Mandate 95

Robin Rolfhamre

Chapter 5 Facing the Soprano: Uncovering a Feminist Performative "I" Through Autoethnography 113 Runa Hestad Jenssen

Chapter 6 Organ Teaching for Children in Norway: An Educational Field in Development 137

David Scott Hamnes

Chapter 7 Bærekraft - lærekraft: Estetiske læringsprosesser gjennom tverrfaglig arbeid i grunnskolelærerutdanningen 167 Anne-Lise Heide

Chapter 8 Evaluering av konsertformidling i høyere utdanning 193 Roy A. Waade \& Anders Dalane

Chapter 9 Dilemmaer i skandinavisk korlederutdanning 215 Dag Jansson \& Anne Haugland Balsnes 
Chapter 10 Woman and Full Professor in Music Education - Work Experiences in the Field of Academia

Carina Borgström Källén

Chapter 11 Experiences and Perceptions of Multiculturality, Diversity, Whiteness and White Privilege in Music Teacher Education in Mid-Norway - Contributions to Excluding Structures

Sunniva Skjøstad Hovde

Chapter 12 Er jeg musikalsk? Barnehagelærerstudenters oppfatning av egen musikalitet 297

Jan Ketil Torgersen \& Morten Sæther

Chapter 13 Music Teachers' and Administrators' Perspectives on Entrepreneurship in Norwegian Higher Music Education: An Exploratory Pilot Study 323 Benjamin Toscher

Chapter 14 The Discursive Terms of Music/Teacher Education at Four Higher Educational Institutions 351

Elin Angelo, Jens Knigge, Morten Sæther \& Wenche Waagen

About the Authors 387

Review Panel 391 


\section{Higher Education as Context for Music Pedagogy Research}

\section{Elin Angelo}

Norwegian University of Science and Technology

Jens Knigge

Nord University

Morten Sæther

Queen Maud University College of Early Childhood Education

Wenche Waagen

Norwegian University of Science and Technology

Welcome to the anthology Higher Education as Context for Music Pedagogy Research.

This anthology is the second publication in the scholarly series MusPed:Research and concerns the field of higher education. The anthology consists of 14 chapters, arranged under the following themes: (i) instrumental music education, (ii) group-oriented and interdisciplinary music education, and (iii) critical examination of music teacher education programs. Before describing the specific chapters, we will first comment on the title of the anthology. These comments, divided into two parts, are contextually and linguistically oriented towards the growth and development of music educational disciplines in Scandinavian, German, and Anglo-American contexts. The first part is titled "Higher Education as Context" and concerns both higher music education and

Citation of this chapter: Angelo, E., Knigge, J., Sæther, M. \& Waagen, W. (2021). Higher Education as Context for Music Pedagogy Research. In E. Angelo, J. Knigge, M. Sæther \& W. Waagen (Eds.), Higher Education as Context for Music Pedagogy Research (pp. 7-17). Cappelen Damm Akademisk. https://doi. org/10.23865/noasp.119.choo

License: CC BY-NC-ND 4.0. 
music teacher education. The second part has the title "Music Pedagogy Research", and builds on the perspectives of Bildung and Didaktik in German/Scandinavian fields within Musikpädagogische Forschung/ musikkpedagogisk forskning.

\section{Higher Education as Context}

Higher music education is organized through a range of disciplines and educational programs and takes place at institutions such as music academies, universities, university colleges, and teacher education programs. In these contexts, music (as a subject in higher education) is focused and understood differently - for example, as performance music studies, as science-oriented studies, or as one of several issues for lifelong learning or community building. From this, there can be huge variations in norms and ways to assess quality, among the different educational- and research cultures. Some research and knowledge development are published as articles in international, peer-reviewed journals, while other research ends up in performance, with concerts, videos, and sound production. The series MusPed:Research is targeted toward the intersection between the many disciplines, educational contexts, and research traditions in the manifold field of music education. As a contribution to grasping the broad field of knowledge, expertise, and identities, a short description is provided of some of the main institutionalized divisions within the disciplines of higher music education.

Musikwissenschaft (Eng: musicology, No: musikkvitenskap) arose as an independent field of knowledge and research in Germany in the last part of the 19th century. An example is Adler's seminal book from 1885, Umfang, Methode und Ziel der Musikwissenschaft. Originally, this knowledge field was focused on analyses and understandings of Western classical music. Today, this field includes a range of approaches and foci, for example ethnomusicology, popular musicology, early music performance, music psychology, music philosophy, and music history (Nettl, 2001; Ruud, 2016). Ruud (2016) also positioned the areas of music therapy, music sociology, and music education within the field of musicology, and hence placed context-oriented and practice-oriented approaches to music within the 
musicological field of education and research. Context-oriented and relation-oriented approaches to music are also labeled as music anthropology (Blacking, 1976) and concern music not only as a "thing" but also as an activity or practice oriented toward nurturing relations and communities (Bartleet \& Higgins, 2018; Elliot, 1995; Small, 1998), and are approaches that have influenced the wider field of music education research (DeNora, 2003; Wright, 2016). According to Nettl (2001), musicology is a field of knowledge "distinguished from other humanistic disciplines in its theoretical (if not always de facto) inclusion of all imaginable kinds of research into music" (p. 288), and he explains that similarly holistic disciplines in other arts, as for example "artology," "dramatology," and "literaturology" seems not to have been developed in North American (in 2001). ${ }^{1}$ Today there exists a range of international research networks and peer-reviewed journals with specified foci, such as cultural diversity in music education $\left(C D I M E^{2}\right)$, sociology of music education $\left(I S S M E^{3}\right)$, music analyses, and philosophy of music education $\left(I S P M E^{4}\right)$. In several of these research journals and networks, teacher practice and teacher training are focused.

Teacher education in Scandinavian and German contexts has also influenced the larger field of music education and music education research. Building on the German traditions of Bildung and Didaktik, music was, from the early days, a primary subject and a main activity both in the compulsory school and in general teacher education in Norway (Jørgensen, 2001; Sætre, 2014). Bildung (No: danning/dannelse, Sv: bildning) can be explained as a philosophical approach to education that concerns both personality development and the socialization of humans to responsible and autonomous individuals (see, for example, Danner, 1994). Didaktik (different from the English word "didactics") can be seen as the science of all the factors that affect education in general (Ger: Allgemeine Didaktik) as well as in specific subjects (Ger: Fachdidaktik) (see, for

1 In Germany, though, Theaterwissenschaft, Literaturwissenschaft, and Kunstwissenschaft have existed for several decades, with professorships and study programs on several universities (e.g., Held \& Schneider, 2007; Knudsen, 1950; Weimar, 1989). In Scandinavian countries similar disciplines exists under names as (in Norwegian): teatervitenskap, litteraturvitenskap and kunstvitenskap. Cultural Diversity in Music Education (CDIME). International Symposium on the Sociology of Music Education (ISSME).

International Society for the Philosophy of Music Education (ISPME). 
example, Seel, 1999). From this, considerable research on music education is provided from general teacher educational perspectives, where pedagogy, didaktik, teaching, and learning are the common references. Today, there exists many kinds of educations in Norway that qualifies candidates to teach music and to conduct music education research. Some of these are hosted by teacher education institutions (for example teacher education for compulsory school and early childhood teacher education) and others by higher music institutions (for example, both performing music educations and musicological educations). This complex scenery of music/ teacher education and ongoing discussions about quality, aims, and ways of articulating form an important background for this anthology and for the chapters that stem from many places in this landscape. One main topic in the confronting exchanges between music-oriented and educationoriented higher education contexts includes how new knowledge is developed and how research should be conducted and what it should look like. Artistic research, or arts-based research with its manifold terminology (artistic development, practice-led, arts-oriented, etc., e.g. Leavy, 2017) has developed as an influential path for research both in higher music education and in teacher education, and challenges traditional, scientific research in questioning the emphasis on verbal reflection, methodological considerations, and literature review.

\section{Music Pedagogy Research}

Musikpädagogik (Eng: music education, No: musikkpedagogikk) developed as an independent area of education and research in Germany starting in the 1970s; 5 For example, through important publications, such as Alt's Didaktik der Musik (1968) and Abel-Struth's Grundriss der Musikpädagogik (1985), which conceptualized and provided a system of terms within the fields of Musikpädagogik and Musikdidaktik, through the

5 In Germany, also other arts subjects have institutionalized own study programs, professorships and research networks in arts specific pedagogies scientific disciplines such as Theaterpädagogik, Tanzpädagogik and Kunstpädagogik. e. g.: Die Gesellschaft für Tanzforschung (established 1986), Die Zeitschrift für Theaterpädagogik (established 1985), IMAGO. Forschungsverbund Kunstpädagogik (established 2014). 
growth of the fields own professorships and study programs in Musikpädagogik at German universities, and through a range of networks and journals focusing on musikpädagogische Forschung (music education research). ${ }^{6}$ The development of musikkpedagogikk and musikkdidaktikk as fields of education and research in Scandinavian countries (especially in Denmark and Norway) drew heavily on the German tradition, with Frede V. Nielsens influencing work beginning in the mid-1970s (Nielsen, 1974, 1998, 2003; see also Benum, 1978; Ruud, 1979; Varkøy, 2003; Vea \& Leren, 1972), while in Sweden also British researchers highly influenced the field's growth (Lindgren et al., 2011). Nielsen has endeavored to introduce and influence the wider field of music education research with a basis of the German traditions of Bildung and Didaktik as a metalevel about learning and teaching music with extensive work over several decades (Nielsen, 2005, 2006, 2007). Georgii-Hemming and Lilliedahl (2014, p. 134) have explained how they distinguish between the terms "music pedagogy and general pedagogy as the science of (music) education" and "(music) education for the practice of teaching and learning (music)" and have also explained music didactics as "the scientific study of all the factors that affect music education and its content" (see also Kertz-Welzel, 2004 and Ferm Thorgersen et al., 2016 for explanations on music pedagogy from this tradition). A main event in the Nordic area was when Frede V. Nielsen, Bengt Olsson, and Harald Jørgensen in 1992 established the research network Nordisk nettverk for musikkpedagogisk forskning (NNPMF)/Nordic Network of Research in Music Education (NNRME), with a yearly conference from 1994, and the annual publication NNMPF/NNRME Yearbook from 1995. Today, study programs and scholarly positions in musikkpedagogikk exist on all levels at universities in Denmark, Sweden, and Norway.

Considerable effort has been made to translate, contextualize, and develop the German tradition of Musikpädagogik and Musikdidaktik to and through the English language (e.g., Georgii-Hemming \& Lillliedahl, 2014; Ferm Thorgersen et al., 2016; Johansen, 2017; Kertz-Welzel, 2004,

6 For example, Arbeitskreis Musikpädagogische Forschung (AMPF; established 1965), Diskussion Musikpädagogik (established 1999), Zeitschrift für Kritische Musikpädagogik (ZfKM; established 2002), and Beiträge empirischer Musikpädagogik (b:em; established 2010). 
2014; Nielsen, 2005, 2006; Vogt et al., 2014).7 Also, arts educational research within other arts subjects has made an effort to differentiate between the term "education" and the term "pedagogy" (e.g., Enghauser, 2007; Risner, 2008). Our aim, in using the term "music pedagogy" in the title of this anthology, is to emphasize philosophical, theoretical, and critical meta-perspectives that are fundamental to the German and Scandinavian traditions of Musikpädagogik/musikkpedagogikk as a widening scope for the discussions in this book. Thus, the diverse chapters concern not only music teaching and learning but also Bildung of humans and societies as such, with concerns articulated about how, where, with whom, from what, and with which intentions such activities happen.

\section{The Anthology's Three Parts and Fifteen Chapters}

The anthology's chapters are organized by three themes: (i) instrumental music education, (ii) group-oriented and interdisciplinary music education, and (iii) critical examination of music teacher education programs.

Part one comprises six chapters, all focusing on aspects of instrumental music education. The first two chapters concern the assessment of instrumental music performance and the difficulties of articulating and operating quality norms in performance music. In Chapter One, Ragnhild Sandberg-Jurström, Monica Lindgren, and Olle Zandén examine views on the criteria for approval in entrance auditions to Swedish performing music teacher programs and problematize these regarding issues of transparency and broadened recruitment. This chapter is titled, "A Mozart Concert or Three Simple Chords? Limits for Approval in Admission tests for Swedish Specialist Music Teacher Education.” Chapter Two, written by Wenche Waagen, is an inquiry of examiners' expectations and understanding of quality in assessing music performance

7 The term "Music Pedagogy" is also used in a contrary meaning to the German/Scandinavian explanation given here, related to specific disciplines. For example, "popular music pedagogy", "piano pedagogy", and "music history pedagogy". This refers to different traditions than we build on in this introduction and is not elaborated on here. 
in student bachelor concerts. This chapter, titled "Vurderingskriterier i utøvende musikk: Et verktøy for pålitelig vurdering av studentenes bachelorkonsert?" [Assessment Criteria in Music Performance: A Tool for Reliable Assessment of the Students' Bachelor Concert?], is theoretically based on Sadlers' distinction between analytical and holistic approaches to assessment. The third chapter concerns the way a principal instrument is emphasized in music teacher education and what kind of knowledge this might provide. Fritz Flåmo Eidsvaag and Elin Angelo are the authors of this chapter, titled "The Craftsmanship That Disappeared? Investigating the Role of the Principal Instrument in Music Teacher Education Programs." In Chapter Four, Robin Rolfhamre uses a philosophical approach to argue that we must give more attention to what, whom, and why we educate, and asks how this affects the teacher's mandate. This chapter is titled "Can We Buy Virtue? Implications from State University Funding on the Musical Instrument Performance Teacher Mandate." In the fifth chapter of the anthology, "Facing The Soprano: Uncovering a Feminist Performative 'I' Through Autoethnography, Runa Hestad Jenssen elaborates on her own path, as a professional musician, toward becoming a feminist and performative researcher. In the sixth and last chapter in this part, David Scott Hamnes examines pipe organ educational praxis for children in Norway. This chapter is titled "Organ Teaching for Children in Norway: An Educational Field in Development," and presents a pedagogical contribution to the field of organ education.

The second part concerns group-oriented and interdisciplinary music education and has three chapters. In Chapter Seven, Anne-Lise Heide examines aesthetic learning processes in a multidisciplinary project in teacher education in Norway, including the subject's music and sports, with a focus on experience, inquiry, and creation. The title of Heide's chapter is "Bærekraft - lærekraft: Estetiske læringsprosesser gjennom tverrfaglig arbeid i grunnskolelærerutdanningen" [Sustainability Learning. Aesthetic Learning Processes Through Interdisciplinary Work in General Teacher Education]. In the eighth chapter, Roy A. Waade and Anders Dalane examine the subject of performance and concert production at a music teacher education program (fagloererutdanning $i$ musikk) in Norway. This chapter is titled "Evaluering av konsertformidling i 
høyere utdanning" [Assessing Music Performance in Higher Education] and employs the Danish concept of Ønskekvistmodellen [The Wishbone Model] to examine how the students in this subject are supervised and assessed. In Chapter Nine, dilemmas in the education of choir leaders are focused. Dag Jansson and Anne Haugland Balsnes here apply theory on communities of practice and didactical theory, and identify significant dilemmas that appear in higher education that qualify choir leaders. The title of this chapter is "Dilemmaer i skandinavisk korlederutdanning" [Dilemmas in Scandinavian Choral Conducting Education].

In the third part of the anthology, five chapters approach the foundation for music/teacher education through diverse lenses of critical theory. In Chapter Ten, "Woman and Full Professor in Music Education - Work Experiences in the Field of Academia" Carina Borgström Källen examines the work experiences of female full professors in music education through a field-oriented and gender-critical approach. In Chapter Eleven, Sunniva Skjøstad Hovde examines how music teacher educators understand the terms "multi-culturalism" and "whiteness/white privileges" and how this is displayed in their everyday lives as music/teacher educators. The title of this chapter is "Experiences and Perceptions of Multiculturality, Diversity, Whiteness, and White Privilege in Music Teacher Educations in Mid-Norway - How They Might Contribute to Excluding Structures." Jan Ketil Torgersen and Morten Sæther are the authors of Chapter Twelve, titled "Er jeg musikalsk? Barnehagelærerstudenters oppfatning av egen musikalitet" [Am I Musical? Early Childhood Teacher Students' Notions of Their Own Musicality]. This chapter is based on a quantitative survey among early childhood teacher students and examines their perception of their own musicality. In Chapter Thirteen, Ben Toscher explores how administrators and educators in higher music education (HME) in Norway define and argue for entrepreneurship as part of HME. This chapter is titled, "Music Teachers' and Administrators' Perspectives on Entrepreneurship in Norwegian Higher Music Education: An Exploratory Pilot Study.” The last chapter in the anthology is written by Elin Angelo, Jens Knigge, Morten Sæther, and Wenche Waagen, and examines how music/teacher education is represented on websites at four institutions in Norway. This chapter is 
critically and theoretically geared through Foucault's concepts of power/ knowledge and governmentality. This fourteenth chapter in the anthology is titled, "The Discursive Terms of Music/Teacher Education at Four Higher Educational Institutions.”

Enjoy the book!

\section{References}

Abel-Struth, S. (1985). Grundriss der Musikpädagogik [Basic outline of music pedagogy]. Schott.

Adler, G. (1885). Umfang, Methode und Ziel der Musikwissenschaft [Scope, method, and goal of musicology]. Viertteljahrschrift für Musikwissenschaft 1.

Alt, M. (1968). Didaktik der Musik: Orientierung am Kunstwerk [Music didactics: Orientation toward the work of art]. Schwann.

Bartleet, B.-L., \& Higgins, L. (Eds.). (2018). The Oxford handbook of community music. Oxford University Press.

Benum, I. (1978). Musikkpedagogiske aspekter [Aspects of music pedagogy]. Norsk musikktidsskrift nr 3 .

Blacking, J. (1976). How musical is man? Faber \& Faber.

Danner, H. (1994). 'Bildung. A basic term of German education. Educational Sciences, (4). https://www.helmut-danner.info/pdfs/German_term_Bildung.pdf

DeNora, T. (2003). Music sociology: Getting the music into the action. British Journal of Music Education, 20(2), 165-177. https://doi.org/10.1017/ So265051703005369

Elliot D. J. (1995). Music Matters: A new philosophy of music education. Oxford University Press.

Enghauser, R. (2007). The quest for an ecosomatic approach to dance pedagogy. Journal of Dance Education, 7(3), 80-90. https://doi.org/10.1080/15290824.2007.1 0387342

Ferm Thorgersen, C., Johansen, G., \& Juntunen, M.-L. (2016). Music teacher educators' visions of music teacher preparation in Finland, Norway and Sweden. International Journal of Music Education, 34(1), 49-63. 10.1177/0255761415584300

Georgii-Hemming, E., \& Lilliedahl, J. (2014). Why what matter. On the context dimensions of music didactics. Philosophy of Music Education Review, 22(2), 132-155. https://www.jstor.org/stable/10.2979/philmusieducrevi.22.2.132

Held, J., \& Schneider, N. (2007). Grundzüge der Kunstwissenschaft [The main features of art studies]. UTB. 
Johansen, G. (2017). Hva er selvkritisk musikkpedagogikk, og hvordan skal vi forholde oss til den? [What is self-critical music pedagogy, and how can we relate to it?]. In K. Stensæth, G. Trondalen, \& Ø. Varkøy (Eds.), Musikk, handlinger, muligheter. Festskrift til Even Ruud (pp. 265-278). NMH-publikasjoner.

Jørgensen, H. (2001). Sang og musikk i grunnskole og lærerutdanning 1945-2000 [Song and music in the compulsory school and in teacher education 1945-200o]. Studia Musicologica Norvegica, 27, 103-131.

Kertz-Welzel, A. (2004). Didaktik of music: A German concept and its comparison to American music pedagogy. International Journal of Music Education, 22(3), 277-286.

Kertz-Welzel, A. (2014). Musikpädagogische Grundbegriffe und die Internationalisierung der Musikpädagogik. Ein unlösbares Dilemma? [Basic concepts of music education and the internationalization of music education. An unsolvable dilemma?] In J. Vogt, M. Brenk, \& F. Heß (Eds.), (Grund-)Begriffe musikpädagogischen Nachdenkens. Entstehung, Bedeutung, Gebrauch (pp. 19-35). LIT.

Knudsen, H. (1950). Theaterwissenschaft. Werden und Wertung einer Universitätsdisziplin [Theater studies: Becoming and evaluation of a university discipline]. Christian-Verlag.

Leavy, P. (2017). Handbook of arts-based research. Guilford Publications.

Lindgren, M., Frisk, A., Henningsson, I., \& Öberg, J. (Eds.) (2011). Musik och kunskapsbildning. En festskrift till Bengt Olsson [Music and knowledge formation. A festschrift to Bengt Olsson]. Art Monitor, Göteborg Universitet.

Nettl, B. (2001). The institutionalization of musicology: Perspectives of a North American ethnomusicologist. In N. Cook \& M. Everist (Eds.), Rethinking music (pp. 287-310). Oxford University Press.

Nielsen, F. V. (1974). Hvad er musikpedagogik? [What is music pedagogy?]. Dansk Musik Tidsskrift, 48(5), pp. 124-130.

Nielsen, F. V. (1998). Almen Musikdidaktik [General music didactics] (2nd ed.). Christian Ejler.

Nielsen, F. V. (2003). Didaktik på tværs af fag. Aspekter i fagdidaktikkens kernefaglighed [Didactics on cross of subjects. Aspects in the core of subject didactics]. In M. B. Nielsen, R. Tønnesen, \& S. M. Wiland (Eds.), Fagdidaktikk på offensiven [Proactive subject didactics] (pp. 12-36). Høyskoleforlaget.

Nielsen, F. V. (2005). Didactology as a field of theory and research in music education. Philosophy of Music Education Review, 13(1). 5-19

Nielsen, F. V. (2006). A view on the future of an international philosophy of music education: A plea for a comparative strategy. Philosophy of Music Education Review, 14(1), 7-14. 
Nielsen, F. V. (2007). Music (and arts) education from the point of view of Didaktik and Bildung. In L. Bresler (Ed.), International handbook of research in arts education (pp. 265-286). Springer.

Risner, D. (2008) The politics of gender in dance pedagogy. Journal of Dance Education, (8)3, 94-97. https://doi.org/10.1080/15290824.2008.10387364

Ruud, E. (1979). Musikkpedagogisk teori [Music pedagogical theory]. Norsk musikkforlag.

Ruud, E. (2016). Musikkvitenskap [Musicology]. Cappelen Damm.

Seel, H. (1999). Allgemeine Didaktik (General Didactics) and Fachdidaktik (Subject Didactics). In B. Hudson, F. Buchberger, P. Kansanen, \& H. Seel (Eds.), Didaktik/Fachdidaktik as science(s) of the teaching profession? (pp. 13-20). Tintee Publications.

Small, C. (1998). Musicking: The meanings of performing and listening. University Press of New England.

Sætre, J. H. (2014). Preparing generalist student teachers to teach music: A mixedmethods study of teacher educators and educational content in generalist teacher education music courses [Doctoral dissertation, The Norwegian Academy of Music]. https://nmh.brage.unit.no/nmh-xmlui/handle/11250/226772

Varkøy, Ø. (2003). Musikk - strategi og lykke: bidrag til musikkpedagogisk grunnlagstenkning [Music - strategy and happiness: Contribution to basic thinking in music pedagogy]. Cappelen akademisk forlag.

Vea, K., \& Leren, O. (1972). Musikkpedagogisk grunnbok [Music pedagogy, basic book]. Norsk Musikkforlag.

Vogt, J., Heß, F., \& Brenk, M. (Eds.). (2014). (Grund-)Begriffe musikpädagogischen Nachdenkens. Entstehung, Bedeutung, Gebrauch [(Basic) concepts of music pedagogical thinking. Development, meaning, application]. LIT.

Weimar, W. (1989). Geschichte der deutschen Literaturwissenschaft bis zum Ende des 19. Jahrhunderts [History of German literary science until the end of the 19th century]. Fink.

Wright, R. (Ed.) (2016). Sociology and music education. Ashgate. 



\title{
A Mozart Concert or Three Simple Chords? Limits for Approval in Admission Tests for Swedish Specialist Music Teacher Education
}

\author{
Ragnhild Sandberg-Jurström \\ Karlstad University \\ Monica Lindgren \\ University of Gothenburg
}

\section{Olle Zandén}

Linnæus University and University of Gothenburg

\begin{abstract}
Against the background of problems with unarticulated concepts of quality and assessment criteria when assessing music, this article concerns how the limit for approval is constructed and legitimised by jurors when assessing entrance auditions to Swedish specialist music teacher education. The data comprise video documented auditions, focus group conversations, and stimulated-recall based interviews, involving jury members at four music education departments. Social semiotic theory is used to study how jurors assess applicants' knowledge representations in main instrument tests, what is considered decisive for an approval, and how this set limit is legitimised. Four approaches have been constructed: the demanding education and profession, the supposed capacity of the applicant, the flexible admission situation, and the care of the applicant. What is considered to be the minimum requirement for approval in these constructions differs markedly, which shows a striking difference between the views of jurors within and between institutions on
\end{abstract}

Citation of this chapter: Sandberg-Jurström, R., Lindgren, M. \& Zandén, O. (2021). A Mozart Concert or Three Simple Chords? Limits for Approval in Admission Tests for Swedish Specialist Music Teacher Education. In E. Angelo, J. Knigge, M. Sæther \& W. Waagen (Eds.), Higher Education as Context for Music Pedagogy Research (pp. 19-40). Cappelen Damm Akademisk. https://doi.org/10.23865/noasp.119.ch1 License: CC BY-NC-ND 4.0. 
how the applicants' musical performances on a main instrument should be assessed. These findings are discussed in relation to two possible scenarios of revised admission tests.

Keywords: admission tests, assessment, music teacher education, social semiotic theory, video observations, interviews

Admission tests with specific selection requirements have long been used as a sorting tool for both specialist music teacher and music performance educational programmes. However, the design of these tests has varied between different educational institutions and programmes as have the skills, knowledge and attitudes tested (Jørgensen, 2009). The eight specialist music teacher programmes in Sweden qualify students to teach a variety of music subjects including instrumental courses at upper secondary schools. To enter any of these programmes, the applicants' have to demonstrate skills on a) a main instrument; b) singing to own accompaniment; c) interplay and musical leadership; d) music theory and aural skills. In every test, juries listen to and assess the applicants' performances based on common criteria and standards communicated by the institutions. In the main instrument tests, the applicants are also ranked for selection to available places. Although the performance at admission tests, and what is recognised as sufficient for approval, seem decisive for accessing applied education, the area is largely unexplored, and there is a great need for research, especially regarding the assessment procedure. In addition, previous research has reported that assessment criteria and norms in higher music educations are not always clearly conceptualised (Harrison et al., 2013; Olsson \& Nielsen, 2018). If unarticulated perceptions of knowledge and quality in music are common in higher music education, the credibility and value of assessments in tests for admission to higher music education programmes may be weakened. In Sweden, as in many other western countries, universities must strive for strengthened societal democracy by promoting broadened recruitment. From this perspective, it is important to review various selection methods, not least given the lack of positive results in a recent Swedish experimental study of aptitude testing and assessment procedures for access to teacher education (Universitets- och högskolerådet, 2018). Hence, the interest in 
this article, which is part of a larger project about assessment of entrance auditions to Swedish specialist music teacher education financed by the Swedish Research Council, is what is considered decisive for approval on main instrument in entrance auditions. The purpose is accordingly to critically examine jurors' views of the limit for approval in main instrument auditions to Swedish specialist music teacher programmes, and to problematise these with regard to issues of transparency and broadened recruitment.

\section{Assessing Music}

Entrance tests with performance auditions on a main instrument are reportedly the most common requirement for both the bachelor of music programmes in Europe (Tomatz, 1996) and the music teaching programmes in USA (Payne \& Ward, 2020). Assessments of performance auditions regarding main instrument are reported to concern technical skills, artistic expression, knowledge of music styles, and communication (Olsson, 1997; Sandberg-Jurström et al., in press). However, assessments of music skills can be seen as complex and problematic, for both applicants, evaluators and institutions, due to lack of transparency regarding what is assessed, how judgments are made in different practices, and how criteria are used and interpreted (Olsson, 2014). The need for greater clarity was called for in a study of ensemble playing in a bachelor of music programme, where teachers' unfamiliarity with documents and procedures, and students' problems with the grading process resulted in confusion and lack of transparency about how to assess ensemble playing (Harrison et al., 2013). Although sharply articulated criteria were used for technical proficiency in music bachelor courses, the assessments of sense of style, expression and communication used fuzzy criteria with lack of appropriate concepts (Olsson \& Nielsen, 2018). Also, non-musical aspects, such as personal traits fitting to teacher profession, are assessed in instrumental tests to specialist music teacher education (Sandberg-Jurström et al., in press), despite lack of such criteria on the institutions, and despite leadership skill tests in other parts of the admission tests. 
Hence, there are many challenges in assessing musical performance fairly and reliably, for example the degree to which a single performance is indicative of the performer's "true" ability. This includes the evaluator's ability to draw reliable conclusions about this ability from a single performance, and intra-rater reliability, for example the effect of previously made assessments on an adjudicator's subsequent evaluations (Bergee, 2007). Analytic criteria, through the use of rubrics and rating scales, are said to be effective by articulating specific aspects of performances (Bergee, 2003; Stanley et al., 2001) and describing what constitutes acceptable performances (Latimer et al., 2010). Analytic assessment has also been a way of addressing both inter- and intra-rater reliability (Bergee, 2003). Several studies have found that analytic assessments result in higher inter-rater reliability than holistic assessments, especially if the holistic assessment is only communicated through a grade (Ciorba \& Smith, 2009). However, as Jonsson and Svingby (2007) notice, there is a risk that "the essence" of a performance can be lost in the pursuit of highly reliable analytic scoring. Likewise, Eisner (2007) argues that judgments in the arts need to bring out the subtle and significant and therefore require refined sensibility narratives and not only the use of measurement. Although analytic criteria provided useful focus during assessment at a tertiary conservatory, examiners preferred fewer criteria and greater focus on subjective responses (Stanley et al., 2001). In spite of using a 30 -item rubric for evaluating solo instrumental performances in secondary school, the jurors still made holistic judgements, especially when the assessments were set in the cut point between different achievement levels (Wesolowski et al., 2018). Also, different results depending on the assessment strategy used have been noticed in bachelor of music programmes. Evaluators using analytic criteria gave higher ratings for technical skills and lower ratings for musical expressions, while the opposite was the case when using own personal criteria (Iusca, 2014). However, Sadler (2015) questions the idea that pre-determined criteria are necessary to make fair and reliable qualitative judgments. He claims that judges can make trustworthy assessments "backwards", by starting from holistic appraisals of a performance and then analysing the criteria (qualities) and standards (degree of these qualities) that are most critical or decisive 
for the overall quality of the assessed artefact or performance. Standards clarified and instantiated by a selection of works or performances can, according to Sadler (2014), enable mutual "tuning" among the assessors. Also, Sadler (2017) points out that the passing grade, the minimum level of achievement, "should represent satisfactory and suitably competent (not marginal) achievement” (p. 93).

Although previous research reports what is assessed, how assessments are made and the effect and questioning of rating resources, little is known of limits for approval. The standards for approval on main instrument at most of the institutions involved in this article are formulated using only two criteria: technical competence and artistic performance, thus opening for fairly holistic assessments. Hence, the main issues in the study are (a) how standards for approval are articulated and interpreted and (b) how the set limit for approval is legitimised.

\section{Theoretical Considerations}

The theoretical framework used in this article is designed to capture how instrumental/vocal skills are represented by applicants' in auditions for specialist music teacher programmes, and verbally articulated and assessed by jurors. Using a social-semiotic approach, individuals' meaning-making activities can be rendered visible through their choice and use of historical and socially available semiotic modes to represent and communicate their understandings of, attitudes to, and interpretations of various phenomena in the social world (Kress, 2010). In this regard, multimodal meaning-making, is seen as the realisation and articulation of particular aspects of the reality in ways appropriate to the interests of social actors in specific contexts. This implies that semiotic modes, such as speech, images and gestures, offering variations of resources, let individuals represent what they regard as knowledge of the world. In such processes the term transduction is used to signal a re-articulation of meaning from one mode to another (Kress, 2010). In the present study, this approach provides the opportunity to see and hear how applicants transduce pieces of music into music performances by using instrumental, vocal and bodily resources as well as musical resources such as dynamics and timing. It 
also provides the opportunity to see and hear what understandings of music style and practice the applicants' express and communicate in their performances. According to Kress (2009), knowledge assessment in an institutional context is intended to recognise signs of learning, i.e. to see the result of a meaning-making engagement. This implies how jurors see, hear and understand the applicants' communicated representations of skills and understandings in order to recognise required knowledge, and how jurors transduce their own multimodal experience into descriptions and evaluations. Thus, the focus in this study is mainly on jurors' verbally expressed values and assessments of the applicants' knowledge representations, and how the jurors legitimise their statements.

\section{Participants and Analysis}

For data collection, video documentation illustrating the use of semiotic resources (Jewitt, 2006), focus group/individual interviews addressing specific themes (Wibeck, 2000), and stimulated recall method for comments on video recorded situations (Calderhead, 1981) were used. The data comprise video documented entrance auditions and audio or video documented conversations with jury members. Some of these were structured individual conversations, while others were focus groups with two to four participants. In all, 59 jury members from four Swedish institutions offering music teacher education programmes participated. The institutions were chosen from a total of eight institutions offering specialist music teacher education programmes, and the selection was based on variation in institutional background, current organization, teacher programme profile and musical genre. Most of the interviews were conducted within two weeks of the entrance auditions, and a few within two months. The jurors were invited to select videos of the auditions they assessed and were asked to comment on the quality of the applicants' performances. They were asked to use the videos to remind themselves of their thoughts and evaluations at the time of the auditions, and the few jurors who were not present at the auditions were simply asked to comment on what they saw and heard in the videos. They were also asked to reflect on entrance auditions for specialist music teacher education in general. 
In the first step of analysis, in order to understand what is going on in the performances, parts of the selected video-recorded sequences were transduced by the researchers into musical scores illustrating what is visible and audible in the applicants' music playing. In the presentation of the findings these transcriptions are visible as well. Furthermore, this step also concerned the researchers short analyses of the transcriptions. The second step of analysis, includes codifying of the jurors' detailed descriptions of what they could see and hear in the applicants' performances, as well as the qualities and skills that caught their attention in the representations. The third step of analysis, concerned distinguishing and categorising variations in the jurors' meta-reflections about what was communicated and recognised as acceptable knowledge and skills in the applicants' representations. In addition to identifying constructions of the acceptable limit for approval, the jurors' rhetorical strategies to legitimise these constructions were also analysed, and what seemed to be at stake when deciding the limit for a pass.

The Swedish Research Council's guidelines regarding information requirements, de-identification, voluntary participation and consent were followed for both jurors and video-recorded applicants. For ethical reasons and the risk for recognition, de-identification has been made without references in the quotations. In presenting the results, no statements or categories are attributed to specific institutions, juries or individual jurors. When a dialogue between jurors is cited, a dash is used before each statement. In the block quotations, deleted passages are indicated with ellipses.

\section{Approaches to the Limit for Approval}

In the analysis of what is considered decisive for an approved main instrument test, and how limits of approval are legitimised, four approaches have been constructed: the demanding education and profession; the supposed capacity of the applicant; the flexible admission conditions, and the care of the applicant. In the following, the researchers' transcriptions and short analyses of excerpts from the auditions are followed by quotations from the jurors' comments on the applicants' performances and the researchers' analyses of jurors' statements. 


\section{The Demanding Education and Profession}

The construction of the demanding education and profession is based on the view that the applicants' knowledge representations, and the limit for approval, must be at a level that ensures good or very good potential for development and prospect for managing the education and the future professional life.

In Figure 1, an applicant's use of vocal and bodily resources are highlighted where the end of an improvised part in a jazz song switches to the regular melody:

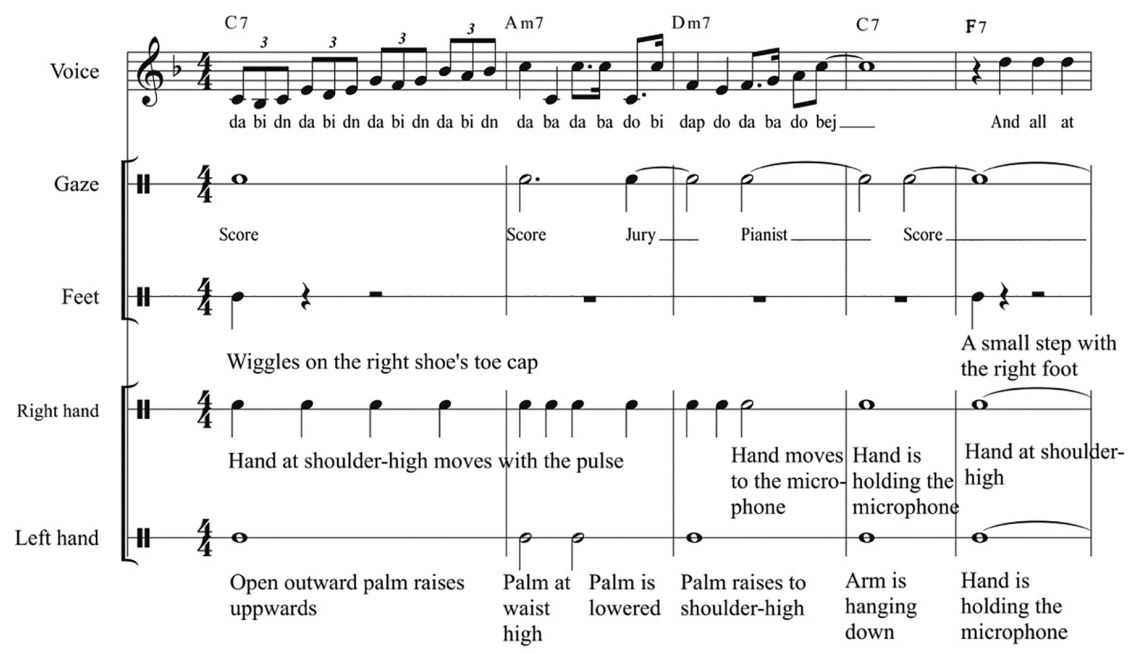

Figure 1 Excerpt from a singer's performance

How the applicant used the voice, intonated and articulated the tones shows signs of some vocal technical skills. The applicant's gaze and the movements with hands and arms can be seen as a communicative act directed both to the pianist in the band and the jury, although the gaze is only directed in these directions a few times during the excerpt. The applicant's use of bodily resources and way of transducing notes and chords into improvised singing can all be seen as a genre-based interpretation. A juror verbalises a similar understanding of the applicant's skills:

I also listen to the feel for rhythm, the timing, and he is very distinct ... What you can hear is that he may not be so much into jazz ... he is not especially 
free rhythmically in his phrasing, but he sings very accurately ... you hear that he is musical ... I think one should sing without the music [in front of him], which he does not, and I would like to see a little more expression ... but he opens a little and communicates with the audience, that is, us ... what mainly makes him approved is that number one, he sings in pitch, he nails the notes, he has a free [sound], he has a very good technique ... he is totally relaxed [in the body].

What is recognised as approved knowledge in this statement is that the applicant has developed good technical and performing skills. It also is suggested that an approved level does not necessarily require much expression, clear bodily communication with fellow musicians, good knowledge of jazz or knowing the music by ear even if this is considered desirable. Necessary representations of knowledge are legitimised as follows:

If you haven't worked so much with shuffle, that is triplet phrasing, then it would be, because we have so much jazz in the education so you need some of that ... it's part of the tools that must be in place to get through ...

It's rhythmically improvised music ... the whole package should be there. It must be anchored rhythmically in the bodies, in the music making, otherwise it will not work.

The requirement to be able to use jazz-related music resources is related to the possibility of managing a five-year music teacher education with focus on the jazz field, which is not seen as feasible without adequate skills. Within this construction also the limit of approval is legitimised through adaptation to the structure of the education, especially with regard to the demands of the ensemble courses, which according to some jurors define the high level:

Yes, and they usually have the ensemble, and it kick-starts. It is not [organised in] ability groups, it is also mixed ensembles and then you look at, will this one manage to get started in this ... has [the applicant] the knowledge to solve or problematise the songs and learn them.

In the symphony orchestra with $\mathrm{XX}$ they play very challenging repertoire. Sometimes it's Beethoven ... It's original stuff. 
The proficiency level needed for participation in the institution's orchestras and smaller ensembles, and the capacity to solve problems that may arise in the repertoire, is taken as arguments for requiring a high level of skills and knowledge. The limit for approval is also legitimised by the small number of instrumental lessons that are provided. Accordingly, the limit for approval is based on adaptation to the structure of the education to ensure quality linked to the education requirements.

The construction of the demanding education and profession is also based on assertions suggesting that the applicant's performed knowledge representations should be at a very high level, equal to the approved limit demanded for admission to a bachelor of music. Since very high instrumental or vocal skills are required in order to cope with the high demands of both the studies and the coming profession, a demand for well-founded technical and interpretative knowledge representations is therefore strongly emphasized. The importance of such skills is exemplified in the statement below:

Now this is university studies and you know what the first year is like. It's pretty tough. There is no time for ten hours a day practicing the violin, so [those skills] must already be at hand, so we need to set a level where they are so skilled that they have time to tackle other subjects the first and second year ... we want those who are self-propelled ... So, for me there is no difference ... the level ... should be at least as high for music teachers as it is for musicians because it is the same profession. And the students we send out from here should be able to take care of all different kinds of children and young people and talents, and be able to help them to become amateur musicians or have great fun in groups or those who want to be able to apply here. And then they have to know a lot.

The excerpt shows how the applicants' knowledge representations are related to, above all, the high demands on skills in the main instrument tests in bachelor music programmes, with the suggestion that the musician and the specialist music teacher require the same high instrumental skills. The demand for a very high level on the main instrument already at the start of the programme is legitimised by the high pace in the studies and the time competition with other courses included in the music teacher programme. Very high demands are also argued for with 
reference to the education's university status as well as to the necessity to secure the future music teacher's need for high instrumental skills. Similar reflections are made by other jurors, for example:

This training programme, at least in our house, requires an awful lot of prior knowledge because you don't have much time for your own instrument ... are we talking about reality or what we want? We want something completely different. We want a Mozart concert, just like the musician programme ... You have to know how the instrument works at that level, having nailed the basic technique, and the left hand speed and position changes, all that.

This statement suggests that the very high requirements for instrumental skills are not always met in the applicant's knowledge representations, but rather constitute a wishful thinking. In other statements, past specialist music teacher educations are highlighted as exemplary, with higher quality requirements and significantly more instrument lessons. This construction thus signals that a change has taken place over the years and that there now is a need for higher demands on the applicants, which in the jurors' statements shows a desire not only to adapt the requirements to the current educational programme, but also to a historical context.

\section{The Supposed Capacity of the Applicant}

The starting point for the construction of the supposed capacity of the applicant is conversations about an absolute lowest, marginal limit for a pass. This construction is based on jurors' reflections on applicants whose knowledge representations are judged to be mostly below the jurors' suggested limit for approval, and therefore between fail and pass, but that are nevertheless being recognised as acceptable. Here, in spite of an applicant's lacking qualifications, the jurors hope that he or she will be able to learn the skills that the education and the profession require.

Figure 2 illustrates an applicant performing their own composition in which music-related resources, such as singing and guitar accompaniment, and bodily resources are used: 


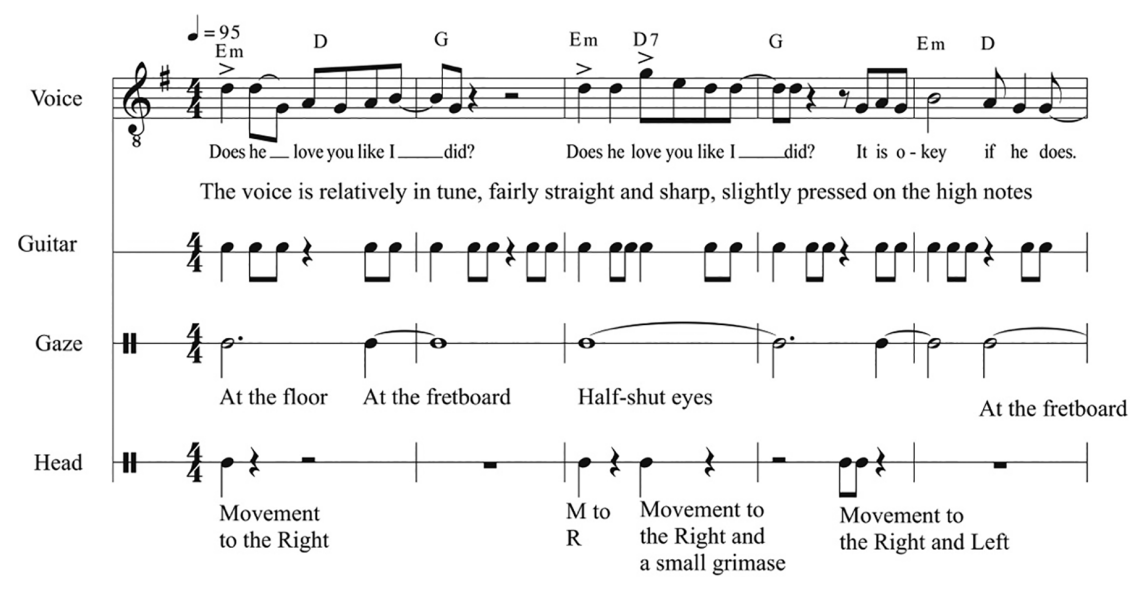

Figure 2 Excerpt from a guitarist's performance

The applicant shows some instrumental technical skills with the voice, as well as with three simple and rhythmically played chords on the guitar. Head movements and directed gazes coordinated with accentuation on certain words can be seen as signs either of genre-based interpretation, difficulties in singing higher notes or attempts at communicating intensity to the listeners (bars 1, 3 and 4). The jurors evaluate the applicant's skills as follows:

Yes, it's only three chords for a very long time and the melody is, yes, it is unbelievably plain. The text is horrible.

The guitar playing, monotonous, without variations, just the typical pop chords everyone plays, nothing original. He doesn't contribute with variation in the accompaniment there, mediocre ... it's exactly the same level of energy, no change.

The applicant's knowledge representations are obviously not recognised as acceptable. The jurors wish for resources such as more interesting text, more chords, originality, varied accompaniment and variations in energy levels. They also miss chords other than those associated with the pop genre, despite the fact that a pop focus is prioritised in this test. In the argumentation about the applicant's communicated skills, there are considerable doubts about an approval: 
He feels very unaware of what music can be, like form, dynamics, phrases, directions, it is just like a single, it is very unaware, very immature and then, he is not really young and the question is, how much can this guy develop given he has not come further at 22 or whatever? How much more can he improve, and should he teach high school students at the high school where all kinds of individuals are studying, including future world stars too. Should they have him as a music teacher?

The suggested lack of musical skills and understanding, the age of the applicant and the development possibilities are related to the opportunity to, within five years, teach music in a high school where some students can be on a very advanced level. However, the applicant was approved, albeit below the very limit for approval, and due to a single, narrowly passed test on another instrument. In jurors' statements, the phrase "benefit of the doubt" is often used, suggesting that inadequacies could somehow be overcome during the education. In this construction a lack of skills on the main instrument can be compensated by skills on other instruments or by competencies shown in other parts of the admission tests. Although the jurors show signs of doubt about an applicant's capacity to cope with the education, may still be admitted if the skills are likely to be developed so that the applicant can become a "decent" teacher. It is also suggested that the tests can be seen as diagnostic rather than excluding, implying that applicants with low skills are suggested to have possibilities to learn enough during five years given the right support. Thus, the "door is slightly open" for these applicants, which might call for institutional adaptation to applicants rather than the opposite.

\section{The Flexible Admission Conditions}

The construction of the flexible admission conditions is based on the idea that the limit for approval does not necessarily have to be fixed, but can be changed depending on contextual and institutional conditions. The view of what is recognised as acceptable skills is considered as dependent on available education places and the number of applicants at the time of application. Also the jurors' views of what to be assessed as well as the 
absence of clearly stated standards are considered to affect the limit for approval.

One applicant drummer's use of the drum set and the body as resources, when playing with a guitarist in a jazz song, is illustrated in Figure 3:

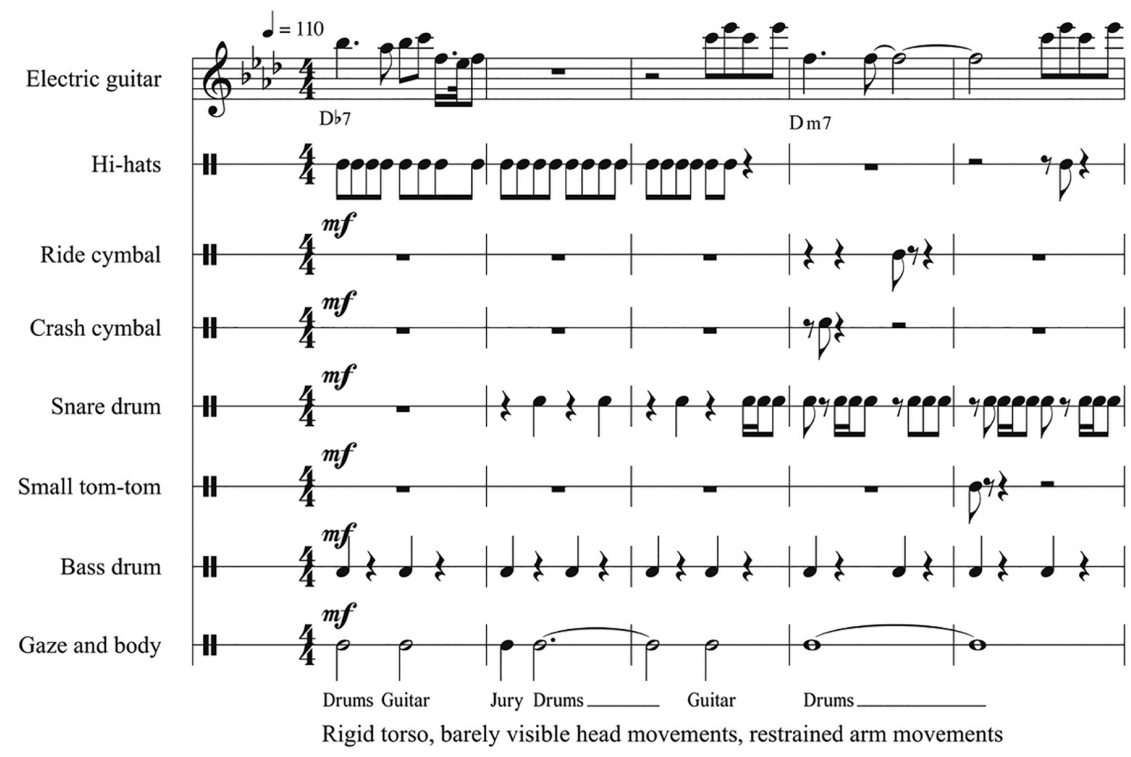

Figure 3 Excerpt from a drummer's performance

The applicant's transduction of the original song to the drum set takes place with a steady and simple drum pattern (bar 1-3) with some added rhythms on the snare drum and the cymbals (bar 4-5). Some communication with fellow players through gazes is visible (bar 1-3). The volume is the same throughout the song, the applicant's body is rigid and the playing is rhythmically static. In the jurors' reflections, several depreciating metaphorical linguistic resources are used:

For the present it is a pass, obviously, but it is puppyish ...

Yes, it is.

But also, the fill-ins, I mean these digidigi, that is. It feels very quiet, aah, young-

ish and a bit, unmusically is the wrong word, but like.

Almost unstructured or nearly careless.

Like, slapish ... 
He is banging himself through it rather than playing, in my opinion.

Interviewer: But what makes him approved, nevertheless?

Well, but he keeps it together, so it doesn't fall like a house of cards ... we're like still standing. It's okay, but he hasn't really added anything. It is very inside, it is very, like, eh, simple stuff and equally thick and bad dynamics, quite uninteresting.

In the juror's dialogue, the low technical level, the dull performance, the rigid body movements and immature performance seem to be redeemed by the playing holding together. Not only is the performance approved, but an even lower level could have been accepted. Also, the applicant's instrumental skills are not considered decisive:

It will nearly always be alright, no matter what level they are at. It's just to take it where they are ... he has the water surface here, you know (points under his nose) ... but he survives, so to speak. It is not here (points over the nose), so it would work in an ensemble situation, though a bit on the border ... but I could actually accept someone doing it even worse. I just want to know, well just feel that it is not completely like black.

Here it is implicated that it is entirely possible to learn what is required during the five-year education provided that the applicant can function in different ensemble situations. What is recognised as crucial is, if anything, the ability to develop further with a teacher's support despite few technical and interpretative resources represented. However, the final decision for approved is legitimised on the basis of institutional and contextual conditions:

Again, it's a bit about how, how broad the line-up is (a dry laughter). This year he probably would have been [accepted], when they are five applicants ... Interviewer: But do you change the limit for approval depending on how many the applicants are?

Well it's about the competition, sort of. Like, we have to have something, so at the end we have to set the bar on the basis of this year's applicants.

The limit for approval here is very flexible, depending on the number of applicants and their result of the tests, given that it is important to fill 
up the places available. It also happens that administrative staff asks for approval despite low scores due to vacant places. The lack of an absolute assessment scale is also considered to contribute to variations of the limit for approval. However, to ensure the quality, admitted applicants are considered to have at least some potential for development. As a result, the level of approval may change year by year at the same institution, and applicants can be assessed on the basis of different premises, depending on the jurors, institution and the admission situation. One consequence of these statements is that the threshold for pass is flexible and unstable with fuzzy conceptions of quality and a strong adaptation to the prevailing conditions.

\section{The Care of the Applicant}

In the jurors' conversations of what cannot be approved, a limit for approval describing what is insufficient and not recognised as acceptable skills, is also expressed. The construction of the care of the applicant is based on statements in which applicants, due to undeveloped and insignificant musical qualities in their performances, are not considered to be able to learn what is required during the course of the education and therefore will not become good enough teachers. Starting the programme with such qualifications would be far too difficult for a future student.

Figure 4a illustrates an excerpt from the original composition and $4 \mathrm{~b}$ the applicant's use of musical and bodily resources when playing four bars from the classic piano repertoire:

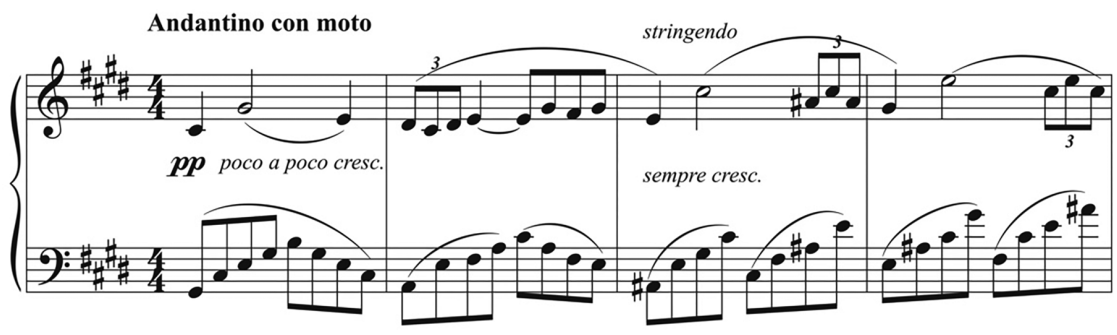

Figure 4a Excerpt from the original composition 


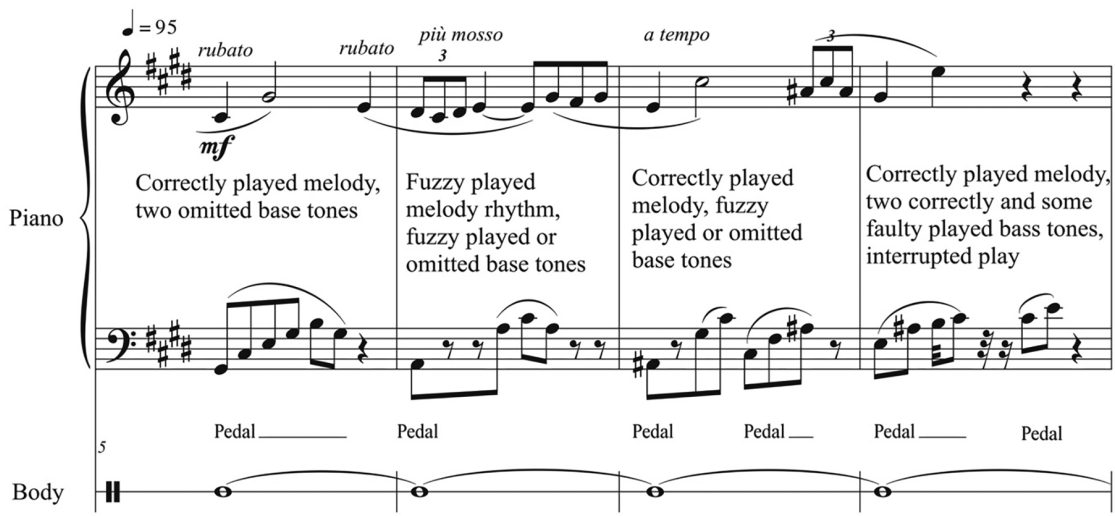

The torso is straight and fairly stiff, illustrated by the whole note in the score. The arms are slightly mobile following the music played. The hands and fingers are rather stiff. The eyes are not in view.

Figure 4b Excerpt from a pianist's performance

The applicant's transduction from the original sheet of music to piano playing includes missing notes, rhythmic indistinctness, an unsteady pulse, relatively too much pedal and a lack of prescribed changes in dynamics and tempo. The performance is interrupted after several flaws. The applicant seems to focus on the printed music throughout the performance, and the body is fairly rigid. Two jurors reflect on the applicant's knowledge representations as follows:

She has already made two mistakes here ... it was a tie and then it was a wrong note and then it was rhythmically a bit limping at the beginning ... then it says piano crescendo and fairly obviously back to pianissimo ... and bit by bit stringendo ... it is very very clear instructions but she has none of that. Exactly the same nuances right through ... it doesn't feel that there is an idea.

There is a lot to do with her hand ... the body is rather free, but she doesn't use her arms in an organic or good way.

The applicant's skills are not considered to be at a sufficient technical or interpretative level given several flaws, such as the rhythmical problems, lack of dynamics and expression as well as improper use of arms and hands. It is considered important to understand, use and reinforce the music with the body. The consequence of insufficient knowledge representations is argued: 
I imagine her in the role of piano teacher, and what kind of musical ideas will you have to give your students, eight or sixteen or whatever [age] they are.

It's troublesome if you start from a too low level, it will not be good for anyone, not the person in question, not for the fellow students, not for the students, or for the students this person will teach, and not for society at large.

You really wouldn't put them in a totally uncomfortable experience. And it's not just that it drags down the others. It can also be very disruptive for their future.

Here, a rejection of applicants is motivated by care for them. Otherwise, they should "probably have a number of tough life stories and sad people". With low skills, it is considered difficult to learn enough to be able to mediate something essential to future students. Low skills on the instrument are also considered to impair the applicants' ability to function in interaction with other students. The level of knowledge is here legitimised as a care of the applicant, since insufficient skills are expected to result in problems both for the applicant and for future fellow students. Thus, this construction emphasizes not only the importance of securing the requirements of the education and profession, but above all the well-being of the future student.

\section{Discussion}

There is a striking difference between the views of how jurors define and argue for limits for approval when assessing applicant's musical performances on main instruments. What is considered to be the requirement for approval differs markedly from the highest level with very high requirements, such as a Mozart concert, to the lowest level with acceptance of major deficiencies, by way of singing and playing three simple chords. The jurors also judge the applicants on the basis of premises other than the criteria and standards communicated to both evaluators and applicants through the institutions' information channels. The applicants' potential for musical development, their capacity to meet the educational and professional requirements and their ability 
to adapt to teachers and fellow students as well as future students, school and society is presented as essential by the jurors. Person-related evaluations of applicants' knowledge representations are also voiced, and it does not seem uncommon that the level for pass is adapted to the ratio of the number of applicants to the available places. Such lack of transparency regarding criteria used to evaluate an applicant has also been reported by Harrison et al. (2013), and by Olsson and Nielsen (2018) who have found unarticulated or fuzzy criteria in higher music education. Also, the varying views regarding competences needed for admission to the education coincide largely with ideas about what and how much is considered necessary and possible to learn during the music teacher education and what competences a future music teacher is expected to possess after completed education. The compass of expected knowledge and skills necessary for admission found in this study is thus paralleled by the scope of exit expectations, from being able to probably become a rather functioning teacher at an ordinary secondary school to becoming a highly-qualified teacher for advanced music students at a music profile upper secondary school.

In the light of these variations, we will discuss the findings from the perspective of the transparency. We also take the opportunity to suggest what to consider when developing the tests by outlining two scenarios. Scenario 1 is related to the design of the admission situations in our study, where jointly set tests and standards are common in most of the institutions. In this scenario, homogeneous specialist music teacher training programmes are strived for, where similar structure, criteria and limit for approval in the programmes require a common lowest level for admittance, here linked to the construction of the demanding education and profession. Based on this scenario, today's skill tests would need to be revised and developed so that they assess only musical skills and knowledge. Analytical criteria would be the basis here, rather than the fairly holistic criteria, with place for a variety of interpretations, that can be said to take precedence today. This type of homogeneous proficiency test has been advocated in previous research and proved effective and reliable (Bergee, 2003; Wesolowski et al., 2018). Furthermore, the joint development of a combination of verbalised and 
instantiated standard for approval suggested by Sadler (2014) could provide the necessary "tuning" and harmonisation of an assessment culture. Such standards could clarify the judgement process, both for applicants and for jurors, and may deter from assessing other competencies than musical skills. Although this scenario would assure transparency to obtain a place on a specialist music teacher programme, no matter where in the country the applicant chooses to study, it could render a broadened recruitment more difficult unless the tests are opened for other traditions of music-making.

Scenario 2 is related to the findings of varying approaches of limits for approval, regardless of jurors, jury groups and institutions. This scenario is based on a completely different logic. Here, variation and pluralism are sought instead of homogeneity, and variation in requirements is seen as an advantage and not a problem. Educational institutions with differing profiles generate different criteria and standards for approval and ranking. Here, Sadler's (2014) clarification of standards through examples can be useful both to provide consistency of grading within institutions and to clarify the differences between institutions regarding demands and profiles. Applicants can then choose a university based on their own musical profile and background, which would create opportunities for applicants with a broader spectrum of competencies to enter a music teacher programme. In this scenario, explicitly marketed variations of requirements for approval between institutions can from a national perspective be a way of widening recruitment to the music teacher profession and thereby contribute to a strengthened democracy. Regardless of which scenario is realised, however, criteria and standards for the approved level, as well as criteria for ranking approved applicants, must strive for transparency in order for the tests to be considered reliable and fair as a selection tool for music teacher education in Sweden.

\section{Funding}

The work was supported by the Swedish Research Council, grant number 2017-03425. 


\section{References}

Bergee, M. J. (2003). Faculty interjudge reliability of music performances evaluation. Journal of Research in Music Education, 51(2), 137-150. https://doi. org/10.2307/3345847

Bergee, M. (2007). Performer, rater, occasion and sequence as source of variability in music performance assessment. Journal of Research in Music Education, 55(4), 344-358. https://doi.org/10.1177/0022429408317515

Calderhead, J. (1981). Stimulated recall: A method for research on teaching. British Journal of Educational Psychology, 52(2), 211-217. https://doi. org/10.1111/j.2044-8279.1981.tbo2474.X

Ciorba, C. R., \& Smith, N. Y. (2009). Measurement of instrumental and vocal undergraduate performances juries using a multidimensional assessment rubric. Journal of Research in Music Education, 57(1), 5-15. https://doi. org/10.1177/0022429409333405

Eisner, E. W. (2007). Assessment and evaluation in education and the arts. In L. Bresler (Ed.), International handbook of research in arts education (pp. 423-426). Springer.

Harrison, S. D., Lebler, D., Carey, G., Hitchcock, M., \& O’Bryan, J. (2013). Making music or making grades? Assessment practices in tertiary music ensembles. British Journal of Music Educuation, 3o(1), 27-42. https://doi.org/10.1017/ So265051712000253

Iusca, D. (2014). The effect of evaluation strategy and music performance presentation format on score variability of music students' performance assessment. Procedia-Social and Behavioral Sciences, 127, 119-123. https://doi. org/10.1016/j.sbspro.2014.03.224

Jewitt, C. (2006). Technology, literacy and learning: A multimodal approach. Routledge.

Jonsson, A., \& Svingby, G. (2007). The use of scoring rubrics: Reliability, validity and educational consequences. Educational Research Review, 2, 130-144. https://doi. org/10.1016/j.edurev.2007.05.002

Jørgensen, H. (2009). Research into higher music education: An overview from a quality improvement perspective. Novos forlag.

Kress, G. (2009). Assessment in the perspective of a social semiotic theory of multimodal teaching and learning. In C. Wyatt-Smith \& J. J. Cumming (Eds.), Educational assessment in the 21st century (pp. 19-41). Springer.

Kress, G. (2010). Multimodality. Routledge.

Latimer, M. E., Bergee, Jr., M. J., \& Cohen, M. L. (2010). Reliability and perceived pedagogical utility of a weighted music performance assessment rubric. Journal of Research in Music Education, 58(2), 168-183. https://doi. org/10.1177/0022429410369836 
Olsson, B. (1997). Is musical knowledge aesthetic or social? A pilot study of knowledge formation in music. Bulletin for the Council for Research in Music Education, 33, 110-114.

Olsson, B. (2014). Vad är grunden för musikaliskt lärande och bedömningar? [What is the reason for music learning and assessment?] In T. Karlsson Häikiö, M. Lindgren, \& M. Johansson (Eds.), Texter om konstarter och lärande (pp. 132-161). Art Monitor.

Olsson, B., \& Nielsen, E. (2018). Tolkningspraktiker och bedömningskulturer - ett projekt om bedömning inom högre musikutbildning. Nordic Research in Music Education, Yearbook 19, 9-23.

Payne, P., \& Ward, J. (2020). Admission and assessment of music degree candidates. Journal of Music Teacher Education, 29(2), 10-21. https://doi.org/10.1177/ 1057083719878388

Sadler, D. R. (2014). The futility of attempting to codify academic achievement standards. Higher Education, 67, 272-288. https://doi.org/10.1007/s10734-013-9649-1

Sadler, D. R. (2015). Backwards assessment explanations: Implication for teaching and assessment practice. In D. Lebler, G. Carey, \& S. D. Harrison (Eds.), Assessment in music education: From policy to practice (pp. 9-19). https://doi.org/ 10.1007/978-3-319-10274-O_2

Sadler, D. R. (2017). Academic achievement standards and quality assurance. Quality in Higher Education, 23(2), 81-99. https://doi.org/10.1080/13538322.2017.1356614

Sandberg-Jurström, R., Lindgren, M., \& Zandén, O. (in press). Musical skills, or attitude and dress style? Meaning making when assessing admission tests for Swedish specialist music teacher education. Research Studies in Music Education.

Stanley, M., Brooker, R., \& Gilbert, R. (2001). Examiner perceptions of using criteria in music performance assessment. Research Studies in Music Education, 18, 46-56. https://doi.org/10.1177/1321103X020180010601

Tomatz, D. (1996). Four European music schools: An NASM perspective. Proceedings of the 72th Annual Meeting (pp. 73-102). National Association of Schools of Music.

Universitets- och högskolerådet [Swedish Council for Higher Education]. (2018). Lämplighetsbedömning av sökande till lärarutbildningar [Aptitude tests of applicants for teacher education]. Stockholm: UHR:s rapportserie 2018:8.

Wesolowski, B. C., Athanas, M. I., Burton, J. S., Edwards, A. S., Edwards, K. E., Goins, Q. R., \& Thompson, J. E. (2018). Judgmental standard setting: The development of objective content and performance standards for secondary-level solo instrumental music assessment. Journal of Research in Music Education, 66(2), 224-245. https://doi.org/10.1177/0022429418765482

Wibeck, V. (2000). Fokusgrupper. Om fokuserade gruppintervjuer som undersökningsmetod. Studentlitteratur. 


\title{
Vurderingskriterier i utøvende musikk - et verktøy for pålitelig vurdering av studentenes bachelorkonsert?
}

\section{Wenche Waagen}

Norges teknisk-naturvitenskapelige universitet

\begin{abstract}
At the Norwegian University of Science and Technology (NTNU), Department of Music (IMU), new assessment guidelines were implemented during spring 2019, which had consequences for the assessment of bachelor concerts. The assessment guidelines offered two substantial new tools for external examiner use in summative assessment: They contained predefined assessment criteria and mark descriptions adapted to the expected learning outcome on the main instrument. In this chapter, I attempt to find out how the new tools function in practice and whether they clarify the task for the external examiners and increase transparency. A focus group interview with six examiners who used the guidelines at IMU is used to shed light on different aspects of the summative assessment. Sadler's theory of qualitative assessment and the twin concepts of holistic and analytic assessment are used as a basis for my discussion.
\end{abstract}

Keywords: bachelor concert, holistic and analytic assessment, marc descriptions, examiners, interview

I stortingsmeldingen Kultur for kvalitet $i$ høyere utdanning (Meld. St. 16 (2016-2017)) varslet regjeringen at den vil stille krav om sensorveiledninger ved alle eksamener, med forhåndsdefinerte kriterier og

Sitering av dette kapitlet: Waagen, W. (2021). Vurderingskriterier i utøvende musikk - et verktøy for pålitelig vurdering av studentenes bachelorkonsert? I E. Angelo, J. Knigge, M. Sæther \& W. Waagen (Red.), Higher Education as Context for Music Pedagogy Research (s. 41-64). Cappelen Damm Akademisk. https://doi.org/10.23865/noasp.119.ch2

Lisens: CC BY-NC-ND 4.O. 
karakterbeskrivelser. Sensorveiledninger presiserer, ut fra emnets læringsmål og innhold, hva studenten forventes å kunne. Hensikten er å bidra til en mer ensartet vurdering sensorene imellom, og å styrke studentens rettssikkerhet og kvalitet $\mathrm{i}$ utdanningene. Tidligere hadde UH-rådets ${ }^{1}$ generelle, kvalitative beskrivelser av vurderingskriterier (UH-rådets utdanningsutvalg, 2016) ligget til grunn ved eksamener i utøvende musikkutdanninger. Rådet for utøvende musikkutdanning (RUM) nedsatte en arbeidsgruppe som utarbeidet felles og fagspesifikke forslag til sensorveiledninger, blant annet i hovedinstrumentfaget. Eksterne og interne sensorer har nå gjort erfaringer med disse. For å utdype min overgripende problemstilling, som er å undersøke hvorvidt forhåndsdefinerte vurderingskriterier i utøvende musikk er et tjenlig verktøy for å fremme pålitelig vurdering av studentenes bachelorkonsert, har jeg stilt følgende tre spørsmål: Hvilke forventninger og forståelser legger sensorer til grunn i møte med studentenes bachelorkonsert? Hvordan erfarer sensorer forhåndsdefinerte kriterier i møte med studentenes bachelorkonsert? I hvilken grad har sensorene nytte av karakterbeskrivelsene?

Sentralt i denne studien står begrepsparet holistisk og analytisk (kriteriebasert) vurdering. Med en holistisk modell utgår sensorer fra helhetsinntrykket av studentens framføring og setter en karakter. Med en analytisk modell utgår de fra forhåndsdefinerte kriterier. I det følgende vil jeg sette eksamenskonserten inn i en utdanningskontekst.

Vurdering i utøvende utdanninger foregår primært i tre ulike situasjoner:

(i) Som diagnostiserende vurdering, under inntaksprøver, der lærerpanelet lytter etter potensial og utviklingsmuligheter. ${ }^{2}$

(ii) Som formativ vurdering (vurdering for læring), der tilbakemeldinger og individuell veiledning har som intensjon å styrke studentenes læring underveis.

1 Dette er et profesjonsråd under Universitets- og høgskolerådet og er et samarbeidsorgan for de utøvende og skapende musikkutdanningene i Norge. Siden 2019: Nasjonalt fagorgan for utøvende og skapende musikk (FUM).

2 I studien til Sandberg-Jurström, Lindgren og Zanden i artikkelen «A Mozart concert or three simple chords? Limits for approval in admission tests to Swedish music teacher education» forekommer både diagnoser og prognoser over søkernes utviklingsmuligheter og potensial for å klare utdanningen. 
(iii) Som summativ vurdering (vurdering av læring), som er den formelle informasjonen til omverdenen om læringsutbyttets kvalitet. Den gir informasjon om studentenes kompetanse, ofte på slutten av et opplæringsløp (Stobart \& Gipps, 1997; Harlen, 2006). Her faller bachelorkonserten inn. Den har en form for eksternt kontrollsystem, med ekstern sensor for bedømming.

Det formaliserte vurderingssystemet for utøvende musikkutdanninger i Norge er vokst fram på bakgrunn av tradisjoner, kultur, særskilte vurderinger av kunstnerisk kvalitet og epistemologiske antagelser. Vurderingspraksiser må ses på bakgrunn av dette. Hovedinstrumentfaget er karakterisert av en individualisert undervisningsform, der den formative vurderingen er en integrert del av samhandlingsmønstret mellom lærer og student. Å være lærer i faget innebærer å utvikle et personlig, nært og subjektivt forhold til studenten. Dette står i motsetning til bachelorkonserten, der det stilles krav om en ikke-subjektiv og distansert holdning. Opplæringstradisjonen kjennetegnes av instruksjon, ofte med søkelys på teknisk og uttrykksmessig artisteri. Den hviler på informert bedømming fra ekspertsensorer som kommer til konsensus, der den eksterne sensoren ofte har hatt siste ord i tvilstilfeller. Sensorene er vanligvis selv utøvere på ekspertnivå.

Bachelorkonserten handler om å kvalitetsvurdere studentens beherskelse av et repertoar, i sanntid, med kun ett forsøk. Etter at studenten har jobbet med sin kunstneriske utvikling i fire år, gis det en formell vurdering basert på den ene prestasjonen. Det er ikke knyttet klagerett til den formelle vurderingen. For studenten blir denne ene eksamenskonserten av desto større betydning. Sadler sier om den summative vurderingsformen at «it is essentially passive and does not normally have immediate impact on learning, although it often influences decisions which may have profound educational and personal consequences for the student» (Sadler, 1989, s. 120). Jeg anser det derfor som maktpåliggende at kvalitetsvurderingen oppleves pålitelig og troverdig, nemlig at man kommer fram til en karakter som kan rettferdiggjøres, med basis i et eksplisitt vurderingsgrunnlag. En kvalitetsvurdering som ikke har tydeliggjort et vurderingsgrunnlag, kan bli oppfattet som esoterisk viten, en type kunnskap som andre ikke har innsyn i. 
Det er en rekke utfordringer knyttet til vurdering av kunstneriske prestasjoner generelt. Det er for eksempel et misforhold mellom den musikalske erfaringen og ordene vi bruker for å beskrive den (Johnson, 1997, s. 272). Musikkutøvelsen har en innebygd kompleksitet, der mange kvalitative og skjønnsmessige aspekter, som klangfarge, følsomhet, nerve, frasering, ekspressivitet og artisteri, gjør den krevende å samtale om. Disse refererer Sadler (1989, 2009b) til med begrepet «multiple criteria». I tillegg til de vanskelig verbaliserbare dimensjonene er det et komplisert samvirke mellom dem, noe som gjør at den overordnede utførelsen innebærer noe mer enn summen av delene. Noen av kriteriene er uskarpe, preget av gradvis overgang fra en tilstand til en annen, i motsetning til fag der epistemisk kunnskap vurderes, og der overgangene er diskontinuerlige. De mange skjønnsmessige aspektene ved musikkutøving er eksempler på abstrakte konstruksjoner med tvetydig mening som må ses avhengig av konteksten. Svaret på kvalitet ligger heller ikke i hver sin ende av et kontinuum av riktig eller galt. I studentens utøving formidles en intensjon: På den ene siden er idealet et personlig uttrykk, på den andre siden skal det være innenfor stilistiske rammer.

Sluttvurderingen gis i form av en bokstavkarakter (klassisk og kirkemusikk) eller som «bestått» eller «ikke bestått» (jazz). Karakteren skal reflektere nivået som er nådd, med basis i standarden for bacheloreksamener, uavhengig av innsats eller læringsprosess. Sadler (1989, s. 129) definerer en standard slik: «A standard or reference level is a designated degree of performance or excellence.» Kvalitetsnivået vil forventes å være ulikt ved en bacheloreksamen og en mastereksamen. Karakteren ledsages gjerne av en samtale der den formelle vurderingen legitimeres. Slik kan den summative vurderingen ha formative elementer i seg (Harlen, 2006). Følgende vurderingskriterier legges til grunn for karakterfastsettelse og tilbakemelding til studenten i utøvende musikk:

\section{Bachelor, klassisk og kirkemusikk}

- musikalsk bevissthet (kunstnerisk uttrykk, tilstedeværelse, karakter, stilforståelse, tolkning)

- kommunikasjon (samspill, publikumskontakt, presentasjon og formidling) 
- instrumentbeherskelse (klangbehandling, frasering, dynamikk, rytmikk, teknikk)

- konserten som helhet (dramaturgi, repertoar, konsentrasjon)

\section{Bachelor, jazz}

- musikalsk bevissthet (gehør- og rytmikkvalitet, harmonisk forståelse, stilistiske aspekter, kreative idéer, formbevissthet, dynamisk sensitivitet)

- sanntidskvaliteter (improvisasjonsevne, nærvær)

- samspillferdighet (rollebevissthet i ensemblet, kommunikasjon, bandledelse)

- instrumentkontroll (klangbehandling, teknikk, variasjon)

- konserten som helhet (uttrykksvilje, konsentrasjon, sjangeroverskridelse, kunstnerisk og konseptuell ambisjon) (Rådet for utøvende musikk, 2018)

Karakterbeskrivelsene har implementert vurderingskriteriene som forventet læringsutbytte. De er uttrykt som ulike kvalitetsnivåer ved prestasjonen, fra så svakt til stede at man ikke anser læringsmålene som nådd (F), til en fremragende prestasjon (A) (se vedlegg). De samme prinsippene ligger til grunn for «bestått» eller «ikke bestått».

I det følgende presenterer jeg tidligere forskning og teoretisk rammeverk for artikkelen. Deretter kommer fokusgruppeintervjuet med datainnsamling, resultater og analyse, med noen mulige implikasjoner av studien helt til slutt.

\section{Tidligere forskning}

Forskningslitteraturen viser ulike oppfatninger av formell vurdering $\mathrm{i}$ utøvende musikk.

Det har blant annet vært en viss motvilje i musikk- og bildekunstmiljøer (Olsson, 2010; Sandberg, 1996), da karaktersystemer har vært ansett som reduksjonistiske på grunn av de estetiske fagfeltenes karakter. Teori rundt musikalsk utøving understreker at den er kompleks og av 
interaktiv natur, der mange faktorer påvirker hverandre samtidig som den skjer i sanntid (Sadler, 1989; Saunders \& Holahan, 1997; Swanwick, 1998). Vurdering basert på helhetsinntrykk, ofte personlig fundert og med få begrunnelser, har derfor karakterisert utøvende instrumentalmiljøer. Ifølge Soep (2004) vil en eksamenskarakter kunne gjenspeile bare deler av helheten, og det vil bli forenklende forklaringer. Andre (Johnson, 1997) har vist til et semantisk problem ved å oversette det musikalske språket til verbalspråk, som aldri kan fange opp nyansene og hvordan parametrene virker sammen. Dette til tross for en rekke studier som understøtter innføringen av kriteriebasert vurdering i utøvende musikk.

Sadler (1985, 1989, 2005, 2009a, 2009b, 2015) har vært sentral i den vurderingsteoretiske diskursen, med klargjøring av vurdering som konsept, funksjonen av vurderingskriterier og med et kompatibelt syn på begrepsparet kriteriebasert og holistisk. Saunders og Holahans (1997, s. 270) studie av 926 søkere til Connecticut All-State Band, som ble vurdert av 36 instrumentaldommere, viser at kriteriespesifikk vurdering kan brukes i vurdering av treblåser- og brasstudenters framføringer, med substansiell reliabilitet. Vurderingsgrunnlaget var tonekvalitet, teknikk og artikulasjon, rytmisk nøyaktighet, interpretasjon og bladlesing. Studien viser til at det framkommer mindre informasjon når alternative vurderingsformer er brukt. Gynnild (2010) gjør en kasusstudie som retter oppmerksomhet mot bruken av kriterier i vurdering av sang, der faglærerne mener redskapet bidrar til en mer konsistent vurdering. Flere har funnet høye nivåer av reliabilitet ved bruk av kriteriespesifikk vurdering (Azzara, 1993; Bergee, 2003; Rothlisberger, 1993). En intervjustudie med 15 lærere ved Sydney konservatorium (Stanley et al., 2002) kartla hvordan lærerne beskrev holistiske og kriteriespesifikke tilnærminger til vurdering. Funnene indikerer at kriterier gir et nyttig fokus, idet de bidrar til å artikulere ønskelige framføringsaspekter som tilbakemeldinger til studentene. Studien konkluderer også med å understreke behovet for at sensorer trenes i et komplementært syn på holistisk og kriteriebasert vurdering, og særskilt i prosedyrer for bruk av kriterier der nivået på studentens framføring varierer i løpet av en solokonsert. Også i Newsome (2015) sin studie, som ble lagt til grunn for utarbeidelsen av de nasjonale sensorveiledningene, argumenteres det for at instrumentalutøvende 
miljøer bør finne en vurderingsmodell som balanserer «the traditional» og «the academic model», med særskilt henvisning til at det vil kunne hjelpe studentene i øvingsarbeidet. Samtidig viser hun til at ren kriteriebasert vurdering kan gjøre at man går glipp av viktige estetiske aspekter som det er umulig å verbalisere. Hun anbefaler derfor et kriteriesett som først utfordrer sensorer til å ta stilling til konserten som helhet, før de tar stilling til et sett med vurderingskriterier.

Vinge (2011) argumenterer for å behandle relasjonen mellom kriteriebasert og holistisk vurdering som et kontinuum istedenfor to adskilte modeller. Ser man til studier fra andre fag som har kommet langt innen vurderingsforskning, for eksempel tekstvurdering, har det vist seg at en «nedenfra og opp»-tilnærming med standardiserte vurderingskategorier gir større grad av pålitelighet og samsvar i vurderinger enn «ovenfra og ned»-tilnærminger (Matre \& Cameron 2018). I dag er høyere musikkutdanninger preget av store forventninger om forskning, publikasjoner, standardisering av emner, grader og posisjoner (Angelo et al., 2019). Hensynet til studentens rettssikkerhet er fremmet med større styrke.

\section{Teori}

Mitt teoretiske utgangspunkt er Sadler og hans begrepspar holistisk og analytisk (kriteriebasert) vurdering. På mange måter argumenterer Sadler for begge modellene, alt etter hvor han er i sin vitenskapelige produksjon. Med den holistiske modellen setter sensorer en karakter basert på helhetsinntrykket av studentens framføring, for så å gi den substans ved å referere til detaljer (Sadler, 2005, s. 179). Vanligvis landes et karakterforslag raskt (Sadler, 2009b, s. 46). Sadler karakteriserer vurderingsmåten som intuitiv eller impresjonistisk. Holistisk vurdering får gjerne karakter av private og subjektive refleksjoner: «With a global approach judges usually employ personally selected criteria to classify, score, or rank a performance in relation to others» (Stanley et al, 2002, s. 47). Thompson og Williamon (2003, s. 26), peker på at erfarne musikere utvikler et slags indre mentalt system, basert på svært høy ekspertise, og til og med et som er spesifikt for det stykket som blir framført. Sadler (2009b) viser til en mulig begrensning ved den holistiske modellen som følge av at sensorer 
kan ha ulike standarder, og av at kjennskap til enkeltstudenters personlighet kan blande seg inn eller føre inn fordommer.

Den kriteriebaserte modellen tar utgangspunkt i en prosedyre der sensorer gjør vurderingen med basis i forhåndsdefinerte kriterier. Disse ses i lys av standarden vurderingshandlingen foregår ut fra. Sadler (1989) definerer kriterier som dimensjoner ved framføringen som er relevante for vurdering. I hvert kriterium ligger et spekter av ulike kvalifikasjonsnivåer. Om man antar at instrumentkontroll og samspillferdighet er sentrale kriterier ved både bachelor- og masterkonserter, vil forventningene måtte tilpasses to ulike, standardiserte nivåer. Sadler (1989) beskriver hvordan kriterier tjener flere viktige funksjoner. For det første minimaliserer de tilstedeværelsen av vilkårlighet og bidrar til detaljerte og eksplisitte tilbakemeldinger til studentene gjennom systematikk. De er nyttige for klargjøring og kommunikasjon, gir substans og konsentrert oppmerksomhet. Videre forenkler kriteriene bedømmelsesprosessen idet de reiser en vurderingsstrategi som lar seg overføre på flere i samme utdanningsklasse. De kan fungere som et verktøy for å undersøke eventuell uenighet i vurderingsprosessen, og et hierarki av utdypende vurderingskriterier viser hvor det kan være aktuelt med kompromisser.

Innvendingene mot forhåndsoppsatte kriterier går på at de ikke klarer å reflektere alle aspekter ved en framføring, og at de kan bli en overforenkling av det sensor hører. Vinge (2011, s. 206) er inne på det samme når han påpeker at det ofte vil være umulig å fastsette klare læringsmål eller vurderingskriterier i musikkfaget, av den enkle grunn at man ikke kan forutse hva elevene «bringer til bordet». Studenters bachelorkonsert kan ha usammenlignbart repertoar, og kriteriene kan falle ulikt ut for ulike sjangre og ulike instrumentgrupper. Kriterier som stilforståelse, uttrykksvilje og intonasjon kan substansielt fortone seg ulikt fra stykke til stykke. Noen kriterier vil være relevante for visse instrumenter og mindre relevante for andre. Intonasjon på et høytpresterende nivå må vurderes ulikt i for eksempel Bernsteins «I hate Music», i Mozarts «Alleluia» og i en blues. «Professional qualitative judgement consists in knowing the rules for using (or occasionally breaking) the rules» (Sadler, 1989, s. 124). 


\section{Kvalitativ vurdering av komplekst læringsutbytte i musikk}

Kvalitativ vurdering i fag med komplekst læringsutbytte er forankret i aksiologiske verdier (Sadler, 1985, s. 287). Disse er en type underliggende eller overbyggende verdier som er mer eller mindre ubevisste for oss selv, noe som stiller sensorer overfor betydelige utfordringer. Eksempler er sannhet, skjønnhet og rettferdighet, og i en bredere utdanningskontekst vil individuelt uttrykk og frihet være aksiologiske verdier. Verdiene er mye mer enn preferanser, smak og behag - snarere er de personlige overbevisninger. Som abstrakte ideer har de utviklet seg i et komplekst samspill av erfaringer, tradisjoner, verdsettelser og sosial diskurs. Disse verdiene kan forklare hvorfor vi betrakter visse kriterier som mer tungtveiende enn andre i vurderingshandlingen, eller hvorfor sensorer fort kan lande på en helhetsoppfatning av konsertframføringen, fordi kriteriene appellerer til en dypt forankret oppfatning av estetisk sensibilitet. Derfor er det viktig at forbindelsen mellom klasseromerfaringer og fundamentale menneskelige verdier drøftes og synliggjøres.

Grunnlaget for holistisk vurdering er innforstått kunnskap, som er basert på årelang erfaring. En musiker kjenner sitt instrument, har hørt en rekke versjoner av den samme trompetkonserten, kjenner den gjennom innstudering og utallige framføringer. Slike lærere prosesserer intuitivt det de hører, til komplekse avgjørelser og indikerer en karakter. I denne studien er «konserten som helhet» definert som et eget vurderingskriterium. Til syvende og sist er «kvalitet» et integrert konsept som består av uendelig mange ulike kriterier, og som karakteriserer et arbeid som helhet (Sadler, 2009b). Sentralt i vurderingen av kvalitet står gjenkjenning. Sadler nærmer seg her det Polanyi (2000) betegner som «tacit knowledge», altså at mennesker sitter inne med en betydelig mengde kunnskap som ikke lar seg artikulere fullt ut. Polanyis legendariske eksempel er gjenkjenning av et ansikt $i$ en stor folkemengde. Kompleksiteten i ansiktet gjør det vanskelig å sette ord på hva vi kjenner igjen, men ikke vanskeligere enn at dagens fantomtegnere blir stadig dyktigere til å konstruere ansikter som ligner mer og mer en verbal beskrivelse. Tilsvarende kan utøvende musikkmiljøers sensorer styrke verbaliseringskompetansen ved å la kriterier spille en 
viktig rolle i kvalitativ vurdering. Resultatet vil bli deres «fantomtegning» av den utøvende prestasjonen som blir vurdert.

\section{Metode}

Datagenereringen har et kvalitativt design basert på fokusgruppeintervju. Fokusgruppeintervjuer framholdes som velegnet når man ønsker å utvikle kunnskap som gir en dypere forståelse av meningsdannelse i gruppen (Madriz, 2000; Wibeck, 2010). Min hensikt med dette var å belyse vurderingsfeltet gjennom en fri uttrykksform der deltagerne kunne dele erfaringer, utveksle meninger og historier relatert til vurderingsutfordringene de alle kjenner til. På den måten ville jeg legge til rette for dataskaping i fellesskap. Samtaleformen bidrar til spontane svar, slik at selve interaksjonen kan generere data.

Utvalg for studien er seks sensorer som var engasjert til bacheloreksamen våren 2019. Det at de var tilgjengelige til samme tid, gjorde det mulig å samle dem til samtale rundt vurderingstematikk. De ble kontaktet en måned i forveien, med invitasjon til å delta. De ble informert om hensikt og metode, om at det ville bli gjort opptak, og om at materialet ville bli avidentifisert og konfidensielt behandlet. Prosjektet var meldt til NSD - Norsk senter for forskningsdata. Alle ønsket å delta. Sensorene representerer en homogen fagkultur som utøvere på høyt nivå: fem med kunstmusikkbakgrunn og en med jazzbakgrunn. Likevel utgjør de et spekter hva angår instrumentfordeling, sjangerfordeling og erfaring. De representerer instrumentene klassisk sang, jazzsang, trombone og orgel. En oppga å være sensor for første gang, to hadde lang erfaring som intern sensor, mens tre oppga årelang erfaring som både intern og ekstern sensor i og utenom norske utdanningsinstitusjoner. Fire var studentenes faglærere. Den formelle sensorveiledningen de brukte under eksamen, er utviklet med tanke på kunstneriske fellesnevnere for et standardisert bachelornivå (Rådet for utøvende musikk, 2018).

Intervjuet ble gjennomført dagen etter at de hadde sensurert studentenes bacheloreksamener. Instituttets studio ble stilt til disposisjon, og en lydtekniker gjorde opptaket. En førstekonsulent fra instituttets eksamensadministrasjon deltok i tilfelle det skulle oppstå spørsmål rundt 
selve eksamensavviklingen. Jeg fungerte som moderator, ønsket velkommen og ledet intervjuet. To momenter ble presisert innledningsvis: At alle skulle forsøke å gi hverandre plass i samtalen, og at det her ikke finnes «rette eller gale» svar. Dette mener jeg forhindret asymmetri mellom deltagerne, og et trygt klima ble etablert. Jeg betrakter det også som et godt utgangspunkt at jeg har en tilsvarende musikkutdanning som intervjuobjektene, og at jeg selv er lærer. Å være på innsiden av tematikken skaper tillit og gjør det lett å følge opp tankegods. Etter intervjuet tok jeg og administrasjonens representant et tilbakeblikk på intervjuet for å oppsummere vårt helhetsinntrykk. Fokusgruppeintervjuet ble deretter transkribert i detalj. Med en liten gruppe sensorer har jeg forsøkt å ivareta forskningsetiske hensyn ved å unngå opplysninger som kan identifisere kildene. Av etiske grunner er også alle sitater oversatt til norsk. Jeg har tillatt meg å stå fritt med tanke på hvilket kjønn jeg tilskriver mine informanter.

Analysen av datamaterialet ble gjort ut fra Giorgis fenomenologiske analysemetode slik den er beskrevet i De Castro (2003), supplert med et hermeneutisk perspektiv (Gadamer, 2010). Metoden åpner for å undersøke både opplevelser, erfaringer og meninger hos sensorene for å beskrive fenomenets essens: vurderinger av kunstnerisk kvalitet. Sensorenes forståelser vokser samtidig fram i relasjonen mellom dem underveis i intervjusamtalen. Tanker om vurderingsprosessen blir dermed noe som også forhandles fram gjennom dialog idet de pendler mellom førforståelse og forståelse, helhet og del. I beste fall oppnår man at gruppas «tacit knowledge» blir gjort eksplisitt om faktorer som kan virke konstituerende på vurderingspraksis. Før min egen utforsking av materialet var det et poeng å ta et skritt tilbake for å tilstrebe undring og åpenhet og å sette min egen førforståelse eller subjektivitet i parentes. I første trinn av analysearbeidet ble det transkriberte intervjuet lest med tanke på å gripe helheten og fange opp tendenser av meninger og mønstre i samtalen, i tråd med fenomenologisk reduksjon: Hva er det som trer fram? Flere historier om bruken av karakterskalaen dukket opp, samt et tilbakevendende ønske om at verktøyene må brukes til å gi støttende tilbakemeldinger til studentene. Så ble intervjuet systematisk gjennomgått for å identifisere meningsbærende elementer som ser ut til å dominere i gruppen, og som 
svarer på forskningsspørsmålene. Dette resulterte i koding av sentrale utsagn som var relevante for fenomenet som skulle utforskes. « $\mathrm{A}$ zoome ut og zoome inn» var et slikt gjennomgående utsagn. Uttalelsene ble analysert og transformert ved å gjengi deltagernes realitetsoppfatning i et fagspråk for å trenge inn i de dimensjonene og utfordringene man møter når man skal verbalisere kvaliteten i det kunstneriske uttrykket.

\section{Resultater}

Resultatene fra intervjuet har gitt innsikt i følgende tre analysekategorier:

(1) forventninger til eksamenskonserten

(2) kriteriebasert eller holistisk vurdering

(3) karakterbeskrivelsenes bidrag i vurderingsarbeidet

Teksten videre er strukturert med disse kategoriene som underoverskrifter. Sensorene benevnes med S1, S2 og så videre. For å være tro mot sensorenes forståelsesprosess vil jeg i det følgende rette søkelyset mot sitater fra intervjuet.

\section{Forventninger til eksamenskonserten}

Fire av sensorene sier de ikke stiller med forventninger til eksamenskonserten, eksemplifisert av utsagnet nedenfor. To kommenterer ikke dette, men er avventende.

S1: Jeg forventer ingenting. Jeg prøver å se hva studenten tilbyr ... utgår fra det.

Så sammenligner jeg forventninger etterpå, jeg prøver å ikke sette opp noe på forhånd. Noen har en konsert rettet mot moderne musikk, ensemblestoff. Noen holder seg innen visse stiler. Noen kan kommunisere med barn. Jeg prøver å la liksom alt komme inn, så jeg prøver å være ganske nullstilt.

Utsagn av denne art viser en av utfordringene ved et sett definerte kriterier som skal gjelde for alle, uavhengig av instrument og repertoar. Samme sensor bemerker også viktigheten av samtalen med intern sensor etter konserten: «Da spør jeg absolutt hvordan det her tilsvarer i hans 
øyne, hvordan den her prestasjonen tilsvarer det forventede. Hevdet det seg? Sank det? Eller var det som forventet? Jeg synes det må også være menneskelig.»

S2 er opptatt av overgangen fra det å ha vært studentens lærer i tre år, til å lytte uten forventninger på denne ene eksamensdagen: «Vi faglærere må nullstille oss. Dette er det som gjelder, å lytte og se med blanke ark. Dette har vi fått streng beskjed om, så det du har tenkt tidligere, kan du bare glemme». $S_{4}$ poengterer at han er sensor for første gang og dermed ikke har eksamenskonteksten å relatere seg til og følgelig ingen konkrete forventninger. Men som aktiv musiker i en årrekke mener han at utøvererfaringen likevel gjør ham forberedt:

S4: Jeg kan bare snakke om det jeg opplevde i går, jeg snakker om én erfaring. Jeg ante ikke hva jeg kunne forvente ... eller ... jeg hadde jo en forventning om å få en opplevelse. Men på hvilket nivå, hadde jeg ingen anelse om. Selv om man ikke lager bevisste forventninger, så har man noe i hodet, en slags uartikulert forventning. Og om man ikke har vært aktiv pedagog, så har man vært aktiv sanger i mange år og hører vel forskjellen på sunt og usunt.

«Sunt og usunt» relaterer etter alt å dømme til studentens stemmebruk og peker mot eksperters intuitive måter å prosessere et auditivt inntrykk over i en karakter på, uten å gå veien om vurderingskriterier.

\section{Kriteriebasert eller holistisk vurdering}

Samtalen indikerer en samstemthet blant sensorene når det gjelder å $ø$ nske forhåndsdefinerte kriterier velkommen. Flere mener at de under eksamen har et lyttefokus som kombinerer helhet og enkeltparametre, og at det foregår en vekselvirkning mellom dem. Likevel kan enkelte uttalelser antyde at de starter med helhetslytting først, for deretter å spesifisere hva denne består av. Følgende illustrer dette:

S1: Ser vi på det som helhetssyn eller som detaljert? Der er egentlig samme ting, det er bare et spørsmål om hvor mye du zoomer inn og zoomer ut. Zoomer du ut, så hører du helhetsinntrykket. Og når du skal gjøre vurderingen, så er du nødt til å zoome inn. Hva var det for mangler som gjorde at den kunstneriske tingen der ikke fungerte? Hva var det som gjorde at det var veldig godt? Da får 
man zoome inn og si at de kvalitetene var helt fantastiske, men de manglene fantes. Så altså: Selvfølgelig synes jeg at det er veldig godt at dette er på papir. Men, altså, både i eksamenssituasjonen og når vi underviser våre egne studenter, så er det jo de her kriteriene vi driver med hele tiden. Den perfekte helheten består jo av en masse perfekte detaljer. Nei, det fins ingen konflikt her, synes jeg, i det hele tatt.

Uttrykket «å zoome inn og zoome ut»er tilbakevendende i samtalen. S4 fastslår at kriteriene hadde hjulpet veldig med å klargjøre egne tanker før konserten, særskilt på bakgrunn av at han var engasjert som sensor for første gang. $S_{3}$ (representerer utøvende jazztradisjon) bringer til torgs betydningen av improvisasjon. Dette er trolig et særskilt viktig vurderingskriterium: «Det vil alltid være et fokus på improvisasjonsevnen, uansett hvilken type musikk jazzstudentene velger å framføre på eksamen, så er det dette å ha det helhetlige overblikket, det ligger der alltid.»

\section{Karakterbeskrivelsenes bidrag i vurderingsarbeidet}

Sensorene problematiserer det de kaller en «inflasjon i toppkarakterer» i utøvende utdanninger, og at studentene faktisk blir skuffet når de får en C. Etter at de har lest karakterbeskrivelsene før eksamenen, gir to av dem uttrykk for at det var oppklarende å se at gjennomsnittskarakteren $\mathrm{C}$ indikerer en prestasjon som viser god kunstnerisk kapasitet og ingen åpenbare mangler. Det vil gjøre det lettere for dem å bruke C i større grad, og å legitimere den. S1 påpeker at han hadde lest opp for en kandidat hva som sto under en $\mathrm{D}$, noe som bidro til at kandidaten forsto at $\mathrm{C}$ var et bra resultat. Dette følges opp av S6: «Veldig ofte kommer vi ut med en A, A, B, $\mathrm{B}, \mathrm{B}, \mathrm{A}$ og har ikke sett skyggen av en C. Jeg var tilfreds i går da vi hadde både en $\mathrm{B}$ og en C.»

$S_{3}$ bringer inn en erfaring med en sensor som ville stryke en student fordi hun ikke hørte noe improvisasjon, men opplevde musikken som komponert. Dette i motsetning til den interne faglæreren som hørte mange improviserte elementer. Det hadde ført til en lengre diskusjon. Her ligger flere dilemmaer: Hvor går skillet mellom improvisert og gjennomkomponert musikk? Hvor mye skal det improvisatoriske elementet vektlegges når studenten ellers viser tekniske og uttrykksmessige ferdigheter 
på et habilt nivå? Hvor går grensen mellom «bestått» og «ikke bestått» i en vurderingsskala med kun to karakterer?

Samtalen ledet etter hvert over på hva studentene kommer til å leve av etter endt studium, om svaret skal ha konsekvenser for hva man vurderer, og om urimeligheten ved å vurdere kun én sluttprestasjon i lys av tre-fire års arbeidsinnsats. Her var oppfatningene differensiert. Et ytterpunkt representeres av $\mathrm{S}_{4}$, som framhever prøvesang for profesjonelle musikere, og «det du presterer der og da, er det som er det avgjørende», noe som legitimerer en tilsvarende eksamen. Det motsatte synspunktet hevdes av $\mathrm{S}$ :

S1: Jeg er enig, sånn ser musikerlivet ut, jeg har selv vært orkestermusiker i 40 år. Ting er sånn her: Det kommer jobb ledig i orkesteret. Det kommer 60-70 søkere. Det er én vinner og 69 tapere. Sånn må det ikke være i en utdanningssituasjon. Går man til et orkesterspill eller livekonsert, da er det der og da det gjelder. Hvor mange av bachelorstudentene som går ut hvert år i Norge, kommer til å leve som utøvende instrumentalister? Dette er en skole, det er ikke en solistkonkurranse. Det er ikke «livet er hardt, og det skal vi vise».

S5 verdsetter de musikktilpassede karakterbeskrivelsene, men uttrykker misnøye med standpunktkarakterer som forsvant. Disse avspeilte studentens innsats over tid. Flere er enige, og følgende uttalelse er representativ:

S1: Hva skjedde med den kontinuerlige evalueringen? Er fire års arbeid intet verd hvis man har en dårlig dag? Forhåpentligvis kan sensorer være så smarte og så erfarne at man hører at her er et menneske som faktisk underpresterer i dag. Da må man telle det til kandidatens fordel. For jeg synes det er helt umenneskelig ... om det er fire års arbeid, så er det plutselig en voldsom deep, og så skal den henge igjen resten av livet.

Både $\mathrm{S}_{1}, \mathrm{~S}_{4}, \mathrm{~S}_{5}$ og S6 tar til orde for at antall sensorer bør være flere enn to. De bruker ord som rettssikkerhet og rettferdighet ved å være tre. Flere foreslår en gjennomgående sensor på alle eksamener:

S1: Vi snakker om rettssikkerhet på studentens vegne ... vi var fire messingblåsere i går. Om en middels god student skal ta sin eksamen, og det er to andre genier, da er det veldig viktig at man sammenligner mot disse kriteriene og ikke 
bare i forhold til hverandre. Om man har en gjennomgående sensor på huset som kan sikre en så objektiv bedømming til karakterskalaen som mulig, så tror jeg det er ønskelig.

S6 påpeker at «for en ekstern sensor er det fare for at en kan føle seg presset av den læreren som har hatt studenten», og da er det fint å være tre. S5 rapporterer gode erfaringer med å trekke studentene selv inn i vurderingsarbeidet gjennom studieåret: «Mange studenter har et ganske sunt syn på hvor de står, og kan godt bli med i den debatten. Dette skjer jo faktisk, i realiteten, hver eneste time.»

\section{Diskusjon}

Sensorgruppas samtale rundt sine «forventninger» til bachelorkonserten avdekker ulike forståelser av hva som ligger i begrepet forventninger, og det kan diskuteres om spørsmålet de fikk, var presist nok. I et hermeneutisk perspektiv møter nemlig ikke sensorene forutsetningsløse til konserten. De har for eksempel rike utøvende erfaringer, de har lest og anvendt kriteriebeskrivelsene, og de vil veksle mellom sin førforståelse av oppdraget og den framforhandlede forståelsen i samtalene med faglærere etter konserten. $S_{4}$ sin uttalelse er treffende: Fra å fastslå at han ikke møter med forventninger fordi dette var det første sensoroppdraget, korrigerer han seg selv i retning av å ha forventninger om en opplevelse, til å lande på at han faktisk har en uartikulert forventning. S2, som er faglærer, ser det som et mål å lytte uten forventninger, som en strategi for ikkesubjektivitet overfor studenter hun har fulgt i tre år. S1 representerer en tredje forståelse, nemlig ikke å lande noen forventninger før han har hørt studentens repertoarvalg og stilvalg, som kan ta ulike retninger. Sistnevnte har i en årrekke vært sensor ved bacheloreksamener, og vedkommende har sannsynligvis en taus kunnskap om standarden i ryggmargen, noe jeg tolker som en forklaring på hvorfor ikke bachelorstandard blir en videre tematikk på dette tidspunktet. Vedkommende vektlegger også samtalen med faglærer etter konserten om hvordan prestasjonene samsvarer med faglærers oppfatninger. Sadler (1985) reiser i en slik sammenheng spørsmål ved om altfor blanke ark kan bidra til at man ikke reflekterer 
i stor nok grad over standarden for vurdering. Det indikeres for eksempel av utsagn som relaterer bachelorkonserten til framtidige prøvespill og prøvesang. Hva vurderes studentene i forhold til? Vurderes de ut fra om de skal bli profesjonelle musikere, eller vurderes de til et bredt yrkesliv? Det er nemlig grunn til å drøfte hvorvidt det legges et for smalt læringsutbytte til grunn for eksamen, så lenge det kun er bachelorkonserten som gjøres til gjenstand for formell vurdering med ekstern sensor. Biggs (1999) viser til at det er mer sannsynlig at studentene oppnår forståelse av fagstoffet når det er samsvar mellom læringsutbytte, læringsaktiviteter og vurderingsformer.

Sensorpanelet skal gjøre sin vurdering ut fra et på forhånd gitt sett med kriterier, der konserten som helhet er et eget kriterium. De uttrykker klart at de ikke ser noen motsetning mellom helhet og del. Sadler (1985) sier om dette at det sentrale er at man ikke betrakter kriteriene som separate, uavhengige dimensjoner, men som elementer av hensiktsmessighet. De må ses i en kontekst. Sensorene mener også at de kontinuerlig veksler mellom å lytte helhetlig og å lytte til de ulike elementene i framføringen. Uttrykket «å zoome inn og zoome ut» dekker dette. Kvale og Brinkmann (2009) viser hvordan en hermeneutisk meningsfortolkning nettopp fordrer en kontinuerlig bevegelse mellom del og helhet og mellom helhet og del, hvor førforståelsen hele tiden må settes på prøve og endres. En førsamtale sensorene imellom, hvor man reflekterer over standarden for bachelor, kunne inngå - og i et bredere yrkesperspektiv enn prøvespill.

Kriterier oppleves som nyttige idet de bidrar til å artikulere tydelig begrunnede tilbakemeldinger til studentene. Dette vil styrke påliteligheten og er i tråd med intervjuundersøkelsen til Stanley et al. (2002). Samtidig viser Sadler (2009b) til at man med ren kriteriebasert vurdering kan gå glipp av samvirket mellom estetiske aspekter, med begrunnelse i de uendelig mange kriteriene som til dels er tvetydige. Skjønt han fastslår at også den holistiske vurderingen i ettertid nødvendigvis må begrunnes med referanse til kriterier (Sadler, 2005, s. 179). Studentene må tidlig i studiet bli gjort kjent med vurderingskriteriene, diskutere dem og utvikle egen vurderingskompetanse. På det viset kan kriterier fungere som en felles referanse for øving, undervisning og 
veiledning. Studentene trenger å høre et stort antall forbilledlige framføringer. Her kan den holistiske vurderingen være et utgangspunkt for å trene på operasjonalisering av begrepene artisteri og kunstnerisk kvalitet. På sin side forutsetter gode øvingsstrategier en kriteriebasert tilnærming.

Det er et spørsmål om ikke det å gjøre sensorers ekspertise til en form for «taus kunnskap» i lengden kan komme til å vanskeliggjøre analyser og saklige diskusjoner omkring vurdering. Rostvall og West (2003) advarer mot historisk legitimerte praksiser i instrumentalopplæringen, med en-til-en-undervisning, som en slags «black box», en privatisert aktivitet der kunnskap og metoder sjelden deles systematisk. Dette vil i verste fall kunne gjøre lærergruppen isolert og gi dem få muligheter for utvikling av undervisningsferdigheter. Profesjonsutøvelse krever også at man kan formidle og begrunne den. Eik (2013, s. 126) trekker fram språkliggjøring som en forutsetning for profesjonsutøvelse, og hun peker på at utøveren også må kunne sette ord på den delen av utøvelsen som preges av skjønn og improvisasjon. Mot denne bakgrunnen vil det å bygge en samtalekultur rundt kvalitet i konsertframføring kunne styrke sensorers og læreres vurderingspraksis og profesjonalitet.

Karakterbeskrivelsene synes å ha positive implikasjoner når det gjelder ettersamtalen med studentene. En indikator er sensorenes erfaring med å bruke karakterbeskrivelsene aktivt overfor studenten for å legitimere en karakter og en større del av skalaen. De fleste sensorene rapporterer erfart misnøye blant studenter som har fått karakteren C. Er det rett og slett kun en ukultur som har utviklet seg rundt eksamenskonserter, at alt under A eller B forteller deg at du ikke er en habil musiker? Har studentene kunnskap om vurderingskriteriene og nivåbeskrivelsene i karaktersystemet? Om dette sier Gynnild (2010, s. 27):

Faktisk er det slik at de aller fleste tilfeller der det forekommer misnøye, er det slik at karakterkriteriene i liten grad er blitt kommunisert på forhånd, og at vurderingen derfor kommer som en overraskelse på studentene.

For å styrke rettsikkerheten til studentene må alle sider ved vurderingen gjøres så transparent som mulig. Studenten må ha innsikt i hvilke kriterier og premisser som legges til grunn, og han eller hun må være 
sikker på at beslutningene skjer på en rettferdig og likeverdig måte. $\AA$ gjøre vurderingskriteriene kjent for studentene tidlig vil kunne styrke læringsutbyttet og kvaliteten i utdanningen. Sensorgruppa bruker selv begrepet rettssikkerhet i forbindelse med karaktersetting. Antall sensorer har betydning. Dette støttes av tidligere forskning (Bergee, 2003; Fiske, 1975, 1977). Bergees studie (2003) viser at påliteligheten $ø$ ker med at vurderingspanelet øker, og gjerne til flere enn tre, aller helst til 5-7. Han tar også til orde for at ikke alle sensorene trenger å være spesialister på samme instrument som studentene. Sensorgruppa anser sluttsamtalen med studentene som det aller viktigste aspektet ved sluttvurderingen.

Dohn (2006) peker på det etisk og kompetansemessig problematiske i å være «intuitiv ekspert» i å sette karakterer. Det leder oss til spørsmålet om det trengs økt bevissthet rundt bruk av skalaen «bestått» eller «ikke bestått». I en rapport fra en arbeidsgruppe oppnevnt av Universitetsog høgskolerådet (2015) slås det fast at også denne skalaen skal relateres til i hvilken grad læringsutbyttet er oppnådd. I rommet mellom de to karakterene ligger en rekke nyanser av kvalitetsnivåer, men hvor ligger minimumsprestasjonen for å få «bestått»? Hva kjennetegner kvalitetsnivået til en student som ikke består? Kritiske samtaler, erfaringsdeling og tolkningsfellesskap vil kunne styrke bevisstgjøring rundt anvendelse av skalaen.

\section{Konklusjon}

Resultatet av denne studien indikerer sensorgruppens støtte til kriteriebasert vurdering av studentenes bachelorkonsert. Kriterier gir potensial for en transparent, argumenterende og pålitelig vurderingspraksis. De har vist seg å være gode verktøy for tydelige og begrunnede tilbakemeldinger til studentene, men de må tilpasses instrumentkontekst, være standardorientert og ikke anvendes mekanisk. Det empiriske materialet peker også mot at de fagspesifikke karakterbeskrivelsene har vært til nytte for sensorene, og at de særskilt har gjort det lettere å legitimere en nyansert bruk av karakterskalaen overfor studentene. Imidlertid har denne studien et lite utvalg, den er hentet fra ett fagmiljø, og den har 
begrenset instrumentrepresentasjon. Den viser derfor at det er behov for å gjennomføre tilsvarende forskning et annet sted med andre informanter for å kunne si noe om hvorvidt materialet også har holdbarhet i en større kontekst.

Det er behov for å knytte sensorers intuitive og holistiske kvalitetsoppfatning til språklig artikulert viten. Det vil komme både sensorer, lærere og studenter til gode, framfor å gjøre ekspertkunnskap til en esoterisk viten som kan komme til å hindre yrkesgruppens utvikling av refleksjons- og vurderingsferdigheter. Et rammeverk for sluttvurderingen synes å kunne styrke fagmiljøene, der læringsutbytte, mål, vurderingsformer og vurderingsskala henger godt sammen og er i tråd med et bredt læringsutbytte og et allsidig yrkesliv.

Det gjenstår mye forskning på hvordan sensorer faktisk ender opp med å gi den karakteren de gir, og på hvordan de vekter ulike prestasjoner i løpet av en students eksamenskonsert. Andre sentrale spørsmål er i hvilken grad sensorer vurderer ved å sammenligne med andre studenter på samme instrument, eller ved orientering mot læringsutbyttebeskrivelser. $\AA$ arkivere sensorers vurderingsmateriale fra eksamenskonserter kan derfor vise seg å bli et godt empirisk grunnlag for videre forskning i vurderingsfeltet.

Denne studien peker mot følgende mulige implikasjoner for praksis ved utøvende musikkutdanninger:

- $\AA$ revurdere små sensorgrupper av hensyn til rettferdighet og pålitelighet.

- $\AA$ A vurdere et bredere, formelt vurderingsgrunnlag til bacheloreksamen.

- $\AA$ trekke studenten aktivt inn i vurderingspraksiser.

- Å utvikle et artikulert tolkningsfellesskap eller fagfellefellesskap for å styrke refleksjonene rundt hvordan kvalitet i utøvende musikk skal bedømmes, og hvordan man kan gjøre disse bedømmingene transparente.

Det vil kreve substansiell utstaking av en kurs der pedagogisk styrking og bevisstgjøring av det utøvende fagpersonalet er et mål. 


\section{Referanser}

Angelo, E., Varkøy, Ø. \& Georgii-Hemming, E. (2019). Notions of mandate, knowledge and research in Norwegian classical music performance studies. Journal for Research in Arts and Sports Education, 3(1), 78-100.

Azzara, C. D. (1993). The effect of audiation-based improvisation techniques on the music achievement of elementary music students. Journal of Research in Music Education, 41, 328-342.

Bergee, M. J. (2003). Faculty interjudge reliability of music performance evaluation. Journal of Research in Music Education, 51(2), 137-150.

Biggs, J. B. (1999). Teaching for enhanced learning: What the student does. Society for Research into Higher Education, 18, 57- 75, Open University Press.

De Castro, A. (2003). Introduction to Giorgi's existential phenomenological research method. Psicología desde el Caribe, 11, 45-56. https://www.redalyc.org/ pdf/213/21301104.pdf

Dohn, N. B. (2006). Karaktergivning - intuitiv ekspertise eller «viden i praksis»? Dansk Universitetspoedagogisk Tidsskrift, 1(1), 38-46.

Eik, L. T. (2013). Ny i profesjonen. En observasjons- og intervjustudie av førskoleloereres videre kvalifisering det første året i yrket [Doktorgradsavhandling, Universitetet $\mathrm{i}$ Oslo]. https://www.duo.uio.no/bitstream/handle/10852/44082/draavhandling-eik. pdf? sequence $=1$ \&isAllowed $=y$

Fiske, H. E. (1975). Judge-group differences in the rating of secondary school trumpet performances. Journal of Research in Music Education, 23, 186-196.

Fiske, H. E. (1977). Relationship of selected factors in trumpet performance adjudication reliability. Journal of Research in Music Education, 25, 256-263.

Gadamer, H.-G. (2010). Sannhet og metode: grunntrekk i en filosofisk hermeneutikk (L. Holm-Hansen, (oversetter)). Pax Forlag.

Gynnild, V. (2010). Kriterier og skjønn i evaluering. En kasusstudie i utøvende musikkutdanning (NOKUTS rapporter nr. 2010 - 4). https://evalueringsportalen. no/evaluering/kriterier-og-skjonn-i-evaluering-en-kasusstudie-i-utovendemusikkutdanning-oktober-2010/Gynnild_Kriterier_og_skjonn_i_evaluering_en_ kasusstudie_2010.pdf/@@inline

Harlen, W. (2006). On the relationship between assessment for formative and summative purposes. I J. Gardner (Red.), Assessment and learning (s. 103-118). Sage Publications.

Johnson, P. (1997). Performance as experience: The problem of assessment criteria. British Journal of Music Education, 14(3), 271-282.

Kvale, S. \& Brinkmann, S. (2009). Interview - en introduktion til et håndvoerk (2. utg.). Hans Reitzels Forlag.

Madriz, E. (2000). Focus groups in feminist research. I N. K. Denzin \& Y. S. Lincoln (Red.), Handbook of qualitative research (2. utg.), 835-850. Sage Publications. 
Matre, M. E. \& Cameron, D. L. (2018). Fører opplæring i felles vurderingskriterier til større grad av enighet? En studie av tekstvurdering som en del av spesialpedagogutdanning. Acta Didactica Norge. 12(4), art. 11.

Meld. St.1 (2016-2017). Kultur for kvalitet i høyere utdanning. Kunnskapsdepartementet. https://www.regjeringen.no/no/dokumenter/meld.-st.-16-20162017/ $\operatorname{id} 2536007 /$

Newsome, E. (2015). A search for balance. The development of a performance assessment form for classical instrumental music in the tertiary context. Assessment in Music Education: From Policy to Practice, 16, 153-170.

Olsson, B. (2010). Bedömning i estetiska ämnen - mer än bra eller dålig konst eller musik. I A. K. Ekholm (Red.), Bedömning för lärande - en grund för ökat kunnande (hefte 3, s. 44-54). Lärarförbundet, Stiftelsen SAF.

Polanyi, M. (200o). Den tause dimensjonen. En introduksjon til taus kunnskap. Spartacus.

Rostvall, A.-L. \& West, T. (2003). Analysis of interaction and learning in instrumental teaching. Music Education Research, 5(3), 213-226.

Rothlisberger, D. J. (1993). The effects of video tape preparation on performance anxiety and its relationship to instrumental music achievement among high school students. Dissertation Abstracts International, 53(7), 2287A.

Rådet for utøvende musikk. (2018). Rapport om sensorveiledninger i høyere musikkutdanning (Rapport). https://s3.eu-north-1.amazonaws.com/nmhnettsted/files/Studier/Sensorveiledninger-i-h\%C3\%B8yere-musikkutdanning.pdf

Sadler, D. R. (1985). The origins and functions of evaluative criteria. Educational Theory, 35(3), 285-297.

Sadler, D. R. (1987). Specifying and promulgating achievement standards. Oxford Review of Education, 13(2), 191-209.

Sadler, D. R. (1989). Formative assessment and the design of instructional systems. Instructional Science, 18(2), 119-144.

Sadler, D. R. (2005). Interpretations of criteria-based assessment and grading in higher education. Assessment \& Evaluation in Higher Education, 30(2), 175-194.

Sadler, D. R. (2009a). Indeterminacy in the use of preset criteria for assessment and grading. Assessment \& Evaluation in Higher Education, 34(2), 159-179.

Sadler, D. R. (2009b). Transforming holistic assessment and grading into a vehicle for complex learning. I G. Joughin (Red.), Assessment, learning and judgement in higher education. https://link.springer.com/chapter/10.1007/978-1-4020-8905-3_4

Sadler, D. R. (2015). Backwards assessment explanations: Implications for teaching and assessment practice. I D. Lebler, S. Harrison \& G. Carey (Red.), Assessment in music education: From policy to practice (s. 9-19). Springer.

Sandberg-Jurström, R., Lindgren, M. \& Zandén, O. (2021). A Mozart concert or three simple chords? Limits for approval in admission tests for Swedish specialist music teacher education. I E. Angelo, J. Knigge, M. Sæther, \& W. Waagen (Red.). 
Higher Education as Context for Music Pedagogy Research (s. 19-40). Cappelen Damm Akademisk.

Sandberg, R. (1996). Musikundervisningens yttre villkor och inre liv. Några variationer över ett läroplansteoretiskt tema [Doktorgradsavhandling]. Institutionen för pädagogik. Lärarhögskolan i Stockholm.

Saunders, T. C. \& Holahan, J. M. (1997). Criteria-specific rating scales in the evaluation of high school instrumental performance. Journal of Research in Music Education, 45(2), 259-272.

Soep, E. (2004). Assessment and visual arts education. I E. W. Eisner \& M. D. Day (Red.), Handbook of research and policy in art education (s. 579-583). Routledge.

Stanley, M., Brooker, R. \& Gilbert, R. (2002). Examiner perceptions of using criteria in music performance assessment. Research Studies in Music Education, 18(1), $43-52$.

Stobart, G. \& Gipps, C. (1997). Assessment: A teachers' guide to the issues. Hodder \& Stoughton.

Swanwick, K. (1998). The perils and possibilities of assessment. Research Studies in Music Education, 10(1), 1-11.

Thompson, S. \& Williamon, A. (2003). Evaluating evaluation. Musical performance assessment as a research tool. Music Perception, 21(1), 21-41.

Universitets- og høgskolerådet. (2015). Retningslinjer for karakterskalaen bestått/ ikke bestått (Rapport). https://www.uhr.no/_f/p1/iec171co6-38f2-4436bce46621a6d32657/rapport_om_bestatt_ikkje_bestatt_10_112015.pdf

UH-rådets utdanningsutvalg. (2016). Generelle karakterbeskrivelser i UHsektoren (Rapport). https://www.mn.uio.no/om/organisasjon/utvalg/ studieutvalg/2018\%20/karakterbeskrivelser-rapport-arbeidsgruppe-stut28.11.18horing.pdf

UH-rådets utdanningsutvalg. (2009). Tilleggsrapport fra arbeidsgruppe for å se næermere på UH-sektorens generelle karakterbeskrivelser (Rapport). https:// docplayer.me/36309836-Tilleggsrapport-fra-arbeidsgruppe-for-a-se-naermerepa-uh-sektorens-generelle-karakterbeskrivelser.html

Vinge, J. (2011). Analytiske og holistiske tilganger til vurdering - en teoretisk drøfting av vurderingsstrategier og vurderingshandlinger i musikkfaget. I S.-E. Holgersen, S. G. Nielsen \& L. Väkevä (Red.), Nordisk musikkpedagogisk forskning årbok 13 (s. 199-220). Norges musikkhøgskole.

Wibeck, V. (2010) Fokusgrupper:om fokuserade gruppintervjuer som Undersökningsmetod. Lund, Studentlitteratur. 


\section{VEDLEGG}

Karakterbeskrivelse for eksamen i utøvende musikk, bachelor (klassisk og kirkemusikk)

\begin{tabular}{|l|l|l|}
\hline Karakter & Betegnelse & Beskrivelse av karaktertrinnene \\
\hline A & Fremragende & $\begin{array}{l}\text { Karakteren reserveres for kandidater som viser kunstnerisk kapasitet } \\
\text { som klart utmerker seg. En fremragende prestasjon som på en } \\
\text { overbevisende måte viser sammenheng mellom valg av musikalsk } \\
\text { materiale, dramaturgi, stilforståelse og tolkning. Kandidaten } \\
\text { demonstrerer et svært høyt teknisk nivå og overbevisende } \\
\text { kommunikasjonsevner med medspillere og publikum. }\end{array}$ \\
\hline B & Meget god & $\begin{array}{l}\text { En prestasjon som viser stor grad av kunstnerisk kapasitet. } \\
\text { En meget god framføring med en overbevisende kombinasjon } \\
\text { av musikalsk bevissthet, instrumentbeherskelse og } \\
\text { kommunikasjonsevne. }\end{array}$ \\
\hline C & God & $\begin{array}{l}\text { En prestasjon som viser god kunstnerisk kapasitet. En framføring } \\
\text { med god musikalsk bevissthet, instrumentbeherskelse og } \\
\text { kommunikasjonsevne. Det er ingen åpenbare mangler ved } \\
\text { framføringen. }\end{array}$ \\
\hline D & Nokså god & $\begin{array}{l}\text { En prestasjon med noen mangler. Framføringen viser likevel } \\
\text { samlet sett musikalsk bevissthet, tekniske ferdigheter og } \\
\text { kommunikasjonsevne på et akseptabelt nivå. }\end{array}$ \\
\hline E & Ikke bestått & $\begin{array}{l}\text { En prestasjon der musikalsk bevissthet, instrumentbeherskelse } \\
\text { og kommunikasjonsevne til sammen ikke tilfredsstiller mer enn } \\
\text { det minimum som skal til for å vise at læringsmålene i emnet er } \\
\text { oppnådd. } \\
\text { kommunikasjonsevne er så svakt til stede at man ikke kan anse } \\
\text { læringsmålene for oppnådd. }\end{array}$ \\
\hline
\end{tabular}

\section{Karakterbeskrivelse for eksamen i utøvende musikk, bachelor (jazz)}

\begin{tabular}{|l|l|}
\hline Bestått & $\begin{array}{l}\text { Kandidaten kan uttrykke seg kunstnerisk, viser akseptabel form- og } \\
\text { stilforståelse, formidlingsevne, gode improvisasjonsferdigheter og tilstrekkelige } \\
\text { instrumentale og musikalske ferdigheter. En helhetlig konsertopplevelse der } \\
\text { prestasjonen viser akseptabel oppfyllelse av vurderingskriteriene, og der man } \\
\text { kan anse læringsmålene for nådd. }\end{array}$ \\
\hline Ikke bestått & $\begin{array}{l}\text { Kandidatens evne til å uttrykke seg kunstnerisk framstår som begrenset. } \\
\text { Konsertopplevelsen som helhet, musikalsk bevissthet, formidling, } \\
\text { improvisasjonsferdighet, musikalsk og instrumental mestring er ikke på et } \\
\text { tilstrekkelig nivå. En prestasjon der oppfyllelsen av vurderingskriteriene er så } \\
\text { svakt til stede at man ikke kan anse læringsutbyttene for oppnådd. }\end{array}$ \\
\hline
\end{tabular}




\title{
The Craftsmanship that Disappeared? Investigating the Role of the Principal Instrument in Music Teacher Education Programs
}

\author{
Fritz Flåmo Eidsvaag \& Elin Angelo \\ Norwegian University of Science and Technology
}

\begin{abstract}
This chapter investigates the role of the principal instrument in music teacher education programs that qualify people to teach music in Norwegian compulsory schools. The data material for the study is the mapping of 12 music teacher education institutions and the reflection notes from six music teacher educators. The theoretical premises for the paper are Aristotle's concept of techné and Fullan's description of deep learning. Techné concerns both technical skills and artistic sensitivity, and this combination provides a framework in which to discuss the educators' reflections about the principal instrument in music teacher education in relation to deep learning, which entails commitment, perseverance, and the learner as a whole human being. This chapter leans on previous studies on music teacher education and the new curriculum for Norwegian compulsory schools, and the concluding remarks point to new perspectives that are needed to evolve music teacher education, concerning both the subject of music and what skills and types of knowledge music teachers should ideally have.
\end{abstract}

Keywords: principal instrument, music teacher education, techné, deep learning

Citation of this chapter: Eidsvaag, F. F. \& Angelo, E. (2021). The Craftsmanship that Disappeared? Investigating the Role of the Principal Instrument in Music Teacher Education Programs. In E. Angelo, J. Knigge, M. Sæther \& W. Waagen (Eds.), Higher Education as Context for Music Pedagogy Research (pp. 65-94). Cappelen Damm Akademisk. https://doi.org/10.23865/noasp.119.ch3

License: CC BY-NC-ND 4.0. 
In March 2018, a group of generalist music teacher students from the Norwegian University of Science and Technology (NTNU) and a group of specialist music students from the Conservatory in Amsterdam discussed the need for specialist music knowledge, principal instrument skills, handicraft, and musical skills in their future profession as music teachers. As part of this discussion, the students were asked by the facilitator to place themselves on an axis from left to right, where the left side reflected the standpoint that specialist music knowledge was crucial for teaching music in school and the right side that specialist knowledge was less important. The Norwegian generalist students generally positioned themselves further to the right and the specialist students further to the left. This reflected a great difference in their views on the knowledge and skills that are necessary for music teachers. This exercise led to a follow-up discussion among the students about how their music teacher education programs emphasize specialist music knowledge differently.

Ongoing discussions in the international field of music education research concern the content, forms, and aims that should constitute music teacher education programs (e.g., Bowman, 2007; Johansen, 2007; Kaschub et al., 2014; Sætre, 2014, 2018). A central topic in these discussions is the relative importance of generalist knowledge and specialized knowledge for the effective teaching of music in schools (e.g., De Vries, 2015; Dobrowen, 2020; Holden \& Button, 2006). In this chapter, we approach this topic by examining how skills with a principal instrument is emphasized in music teacher education programs that qualify people to teach in Norwegian primary and secondary schools. Historically, music education builds on a master-apprentice tradition, wherein a master (for example, of the violin or piano) teaches learners at various levels (Gies, 2019). This tradition is also found in music teacher education programs in Norway (Sætre, 2014). Today, this tradition is challenged or supplemented by music technology, and there is reason to believe that the same challenges concerning authentic and inauthentic learning and learning spaces as presented by Eiksund and Reistadbakk (2020), is also valid in the education of music teachers. For teaching classroom music in primary and secondary schools, the debates center on who are best suited 
as teachers, those with expertise on an instrument or those with expertise in classrooms and teaching young pupils (Daniel \& Parkes, 2017; De Vries, 2015; Hennessy, 2000; Holden \& Button, 2006; Rusell-Bowie, 2009; Seddon \& Biasutti, 2008; Wiggins \& Wiggins, 2008). These debates reveal a lack of confidence among generalist school teachers towards teaching music, which does not necessarily correspond to a lack of skills or formal music education. The debates also point to a frequent notion about music as a "special" subject in school that requires and nurtures given talent (Hennessy, 2000; Ruddock \& Leong, 2005; Russell \& Bowie, 2013). We aim to contribute to these discussions by examining the research question: How is a principal instrument emphasized in music teacher education in Norway? We were curious to find out how much time is dedicated to the student's principal instrument in diverse music teacher education programs and how music teacher educators reflect upon the time spent on principal instruments. Our data material for this study is derived from (1) a survey of institutions that offer music teacher education programs qualifying people to teach music in Norwegian primary and lower secondary schools and (2) reflection texts from six music teacher educators working in these institutions. By using the theoretical and philosophical premises from Aristotle's concept of techné and the concept of deep learning in educational theory and curricula (Fullan \& Langworthy, 2013; Fullan et al., 2018; NOU, 2015: 8), the discussions about the role of the principal instrument in music teacher education can be deepened and the division between generalist/specialist musical skills challenged.

Our motivation for this study partly relates to the new curriculum for primary and lower secondary schools introduced in Norway (2020) ${ }^{1}$ and to its increased focus on music as a practical and creative subject, as well as the introduction of the concept of deep learning in the curriculum. For example, music is presented as a subject with creative power that fuels the pupil's urge to explore, create, and experiment. Deep learning concerns the pupil's gradual development in understanding the concepts, systems,

1 Fagfornyelsen [the Renewal of subjects]/ LK2O is an education reform gradually introduced in Norwegian primary, lower secondary, and upper secondary education and training during 2020. See https://www.udir.no/laring-og-trivsel/lareplanverket/fagfornyelsen/hva-er-nytt-fagene-les-vare-korte-oppsummeringer\#147424 
methods, and contexts within a particular subject area, as well as topics and issues that intersect several areas. Central to the idea of deep learning is that students engage in analyzing and problem-solving and that they reflect upon their own learning to construct a lasting understanding (NOU, 2015: 8). These aspects of deep learning make it relevant for examining the place of the principal instrument in music teacher education. Our motivation also builds on previous research on the subject of music in compulsory schools in Norway (e.g., Bandlien, 2019; Dobroven, 2020; Fredriksen, 2018) and other Scandinavian countries (e.g., GeorgiiHemming \& Westwall, 2010; Holgersen \& Holst, 2020; Lindgren \& Ericsson, 2011) and international research on music teacher education (e.g., Bowman, 2007; Kaschub et al., 2014). A main topic in this research is how music education in schools can be understood as an individual pursuit, with little support provided by the school as an organization and the professional community (Benedict \& Schmidt, 2014; Dobrowen, 2020; Fredriksen, 2018; Georgii-Hemming \& Westwall, 2010). Another major topic is the underlying tension between the positioning of the subject of music as an arena for the pupil's general growth and well-being, or as an arena in which to gain specific musical knowledge and skills (Bowman, 2007; Lindgren \& Ericsson, 2011). A third main topic relates to the music teacher's competence, background, and tasks, and to the critical questioning of who is best suited to teach music in the compulsory school; the specialized music teacher or the generalist teacher who teaches music as one of several school subjects (Dobrowen, 2020; De Vries, 2015, 2013; Hennessy, 2000; Holden \& Button, 2006; Wiggins \& Wiggins, 2008). Previous research elaborates on how teachers with different educational backgrounds, as specialists or generalists, tend to choose different content and activities in their music teaching. For example, Sætre et al. (2016) found that teachers in the lower grades (1-4) often are female, seldom use instruments in their classes, and have low participation in nonformal musical activities outside of school (choirs, wind bands, etc.), while music teachers in the higher grades often are male, use instruments, and are more oriented towards individual musical activities, such as composing, listening, and playing. Interestingly, a study about music and other arts subjects in generalist teacher education in Sweden (Lindgren 
\& Ericsson, 2011) revealed that a lack of specialized competence is seen as a sign of pedagogical quality, as this equalizes the position between the teachers and the students and makes the subjects (e.g., music) seem less threatening.

In this chapter, we follow up on the discussion between the Norwegian and Dutch music teacher students (from the start of the chapter), by examining how a principal instrument is emphasized in music teacher education programs. The chapter has four parts. The first part elaborates on the concepts of techné and deep learning, which serve as the theoretical premises for our discussion. The second part explains our research design: (i) how we mapped the diverse music teacher educational programs that exist in Norway, and the hours spent on a principal instrument in these programs, and (ii) how we conducted the work of gaining reflection notes from six educators in these programs. After analyzing and discussing these in the chapter's third part, we end the chapter with some concluding remarks on the (perhaps artificial) division between specialist and generalist music teachers, and about a possible reconsideration of principal instruments in transgressive and transformative music teacher education.

\section{Theoretical Perspectives}

To theoretically dive into the new curriculum's emphasis on practical and creative work in music and deep learning, Aristotle's concept of techné serves as our entrance. Our use of the term techné is philosophically geared through Heidegger's philosophy on art, and music-pedagogically geared through Varkøy et al.'s thoughts about music and craftsmanship (Aristotle, 2011; Heidegger, 2006; Varkøy et al., 2020). The Greek concept of techné (English: art) concerns the necessary knowledge of bringing something new into the world and implies both technical skills and artistic sensitivity. Technical skills are undoubtedly needed to play an instrument, and performing musicians need technical knowledge. This knowledge may also be necessary for music teachers in teaching pupils to play and sing alone and together with others. However, the Aristotelian term techné does not refer to mere technical skill, but rather to 
the knowledge that allows one to perceive the sense of "being" and be able to put this into one's work, in artworks (Heidegger, 2006). Related to music and art, this interpretation of techné coincides with the term "handicraft" and with the aesthetic aspects of artistic expression and craftsmanship. In this sense, handicraft does not relate to mere technical skill but to a way of knowing that is crucial for bringing something new and authentic into the world. In this view, techné (both skills and sensitivity) is needed to "do" (make/create/explore) music, as required in the curriculum (The Norwegian Directorate for Education and Training, 2019). Importantly, techné is not about the superficial skills needed to reproduce (as machines) but is deeply rooted in the essence of human beings. Music, understood as an object, is also suggested to imply depth, with different layers of meaning that correspond to different layers of human consciousness (Nielsen, 1998, pp. 137-139). From this perspective, refinement in playing a principal instrument can be seen as revealing forms of knowledge that contain depth in relation to the craft, the music played, and the human being.

The concept of deep learning has flourished in international educational literature and research from mid-20oo and is heavily emphasized in the 2020 curriculum for compulsory schools in Norway (Ministry of Education and Research, 2017; NOU, 2015: 8). This idea can be traced back to the mid-197os (Marton \& Säljö, 1976) and refers to the distinction between surface learning (simple memorization of new ideas) and deeper learning (actively integrating new ideas with previous knowledge and creating new connections between concepts) (Ahrony, 2006; Biggs, 1999). The concept of deep learning has been employed in general research on education, teaching, and learning (e.g., Biggs, 2004; Filius et al., 2018; Hay, 2007), in research on different subjects and in diverse contexts (e.g., Rillero, 2016; Hall et al., 2004), and in music education research (e.g., Ferm \& Johansen, 2008). So far, however, we have not found studies that employ this term specifically with regard to teaching and training in a principal instrument. Garrison et al. (2001) emphasized that the whole person needs to be engaged to promote deep learning cognitively, socially, and affectively. Deep learning is thus meaningful learning that goes beyond the acquisition of new skills and information. 
Michael Fullan and his colleagues explain deep learning as a means to develop learners to become creative, connected, collaborative, engaged, and healthy individuals with skills to pursue their own visions in an ever-emerging world (Fullan et al., 2018, 2013). Fullan describes deep learning skills as concerning character (e.g., honesty, self-regulation, perseverance, responsibility, and self-confidence), citizenship (e.g., sensitivity and respect for others), communication, critical thinking, problem solving, collaboration, creativity, and imagination. The Ludvigsen Committee $^{2}$ (NOU, 2015: 8), which has thoroughly prepared and influenced the new curriculum in Norway, defines deep learning as the understanding of concepts and interrelationships within one discipline or across disciplines, which is developed and nurtured gradually and over time. They explain deep learning as characterized by processes in which the pupils become absorbed by the learning material over time, are given suitable challenges, and receive useful feedback. The students' own reflections on their learning are emphasized as necessary to improve their understandings of the connections between disciplines (NOU, 2015: 8, p. 14). However, a critique of the curriculum's explanation of deep learning is that it is one-sided, targeted towards the cognitive perspective of learning, but lacks the perspectives of childhood and adolescence, as well as humanity and society as a whole, which are needed to fully grasp the complexity of learning in primary and secondary schools (Østern et al., 2019). In our study, the tensions and topics around the concept of deep learning, as related to the above discussions of the concept of techné, serve as a framework in which to discuss the mapping and the reflections on the importance of principal instruments in music teacher education.

2 The Ludvigsen Commitee's mandate was to assess and report on what pupils need to learn in school in a perspective of 20 to 30 years (NOU, 2015: 8, p. 3 ). 


\section{Research Design}

In Norway, several paths can be chosen to gain formalized qualifications to teach music in primary (grades 1-7) and secondary (grades 8-10) schools. Some of these paths are clearly targeted towards music and musicians, with pedagogical courses as an add-on education. Others are clearly targeted towards classroom teaching and the teacher profession. ${ }^{3}$ To gain an overview of this varied landscape, our first step was to map what education programs confer the formal qualification of music teacher in compulsory schools in Norway, and the amount of lesson hours on a principal instrument these programs offer. Our second step was to approach six music teacher educators from the two types of music teacher education programs that are most targeted towards the teacher profession (types 1 and 2, which will be explained in the results section) and ask them to reflect openly on four questions about the role of the principal instrument in their education.

In 2018-2020 we conducted the mapping part first through finding the diverse institutions that offer music teacher education in Norway. This information was found in the Ministry of Education and Research's list of state-owned universities and university colleges ${ }^{4}$ and through web searches of private institutions, such as the Barratt Due Academy. In total, 12 institutions were located. Secondly, we found the relevant contacts and e-mail addresses via the different institutions' web pages and forwarded our questions to the music education program leaders. These questions concerned (1) the amount of principal instrument lessons given to each student during their music teacher education, and (2) the duration of these lessons (appendix 1). These steps provided us with the information to map the landscape and identify huge differences in the amount of lesson time given to principal instruments and the duration of these lessons (appendix 3). To further explore how the principal instrument was viewed in these education programs, we needed qualitative data. To generate these, we designed a short reflection note, with four questions, and emailed them to six music teacher

3 In reality, almost $60 \%$ of those who teach music in the compulsory schools have no credit points in music, but this study does not focus on that aspect (Statistisk Sentralbyrå, 2019).

4 https://www.regjeringen.no/en/dep/kd/organisation/kunnskapsdepartementets-etater-og-virksomheter/Subordinate-agencies-2/state-run-universities-and-university-co/id434505/ 
educators (later referred to as E1-E6), including a question on their willingness to participate. E1-E3 are from the specialist music teacher education (SMTE) and E4-E5 are from generalist teacher education (GTE). E6 is from both SMTE and GTE. These six reflection notes are seen as examples, not as representative of music teacher educators' views on the place of the principal instrument in music teacher education. The questions were designed to encourage freely written reflections on the educators' meanings about the role of the principal instrument in their education (appendix 2). The written form was chosen to provide the teachers with the freedom to write and revise whenever they had time.

The analysis of the reflection texts was done through a qualitative, inductive approach, identifying the reoccurring themes across the texts (Braun \& Clarke, 2006; Creswell \& Creswell, 2018). The six reflection texts (altogether 20 pages) were arranged in groups relating to what kind of music teacher education program the educators were engaged in: (i) specialist music teacher education or (ii) generalist music teacher education. Secondly, we read the texts with the aim of grasping a general description of these programs, along with the overall meanings ascribed to the role of the principal instrument in these programs. To facilitate this process, we wrote notes in the margins of the texts, collected these notes in a new document, and used these to write a small description of the two programs, which is presented in the results section of this chapter. As a third step, we aimed to identify the reoccurring aspects that the six educators expressed across the programs and then form these into themes for deepening the discussion. This step was implemented through a process of further synthesizing the reflection texts, bracketing segments and highlighting words and expressions that reoccurred in the six texts. From this investigation, we identified three themes: subjectspecific, human-specific, and learning-specific. These themes were then advanced and discussed by mirroring them against the concepts of techné and deep learning (Aristotle, 2011; Heidegger, 2006; Varkøy et al., 2020). Our backgrounds and experiences as music teachers and music teacher educators were both fruitful and challenging in this analytical work; fruitful because we could relate to the contexts and practices described and challenging because we aimed for the analysis to 
grow from the data and not from our background and preunderstandings. To meet this challenge, we constantly returned to the raw texts throughout the whole process and adjusted the in-progress analysis of the descriptions and the wording of the themes with regard to what the six educators actually wrote. In the following section, quotes and critical questions are provided to improve the transparency of the research process. This study has been conducted in line with the Norwegian Guidelines for Research Ethics in the Social Sciences, Humanities, Law and Theology (NESH, 2016) and the guidelines and requirements from the Norwegian Data Protection Services (NSD). All six educators who provided reflection notes are anonymized, and direct consultation with the NSD has ensured that the whole research process is conducted in line with the GDRP rules for privacy protection.

\section{Results and Discussion}

\section{The Mapped Landscape}

Several paths can be followed to gain formal qualifications as a compulsory school music teacher in Norway. This study's first step provided us with an overview of the diverse music teacher education programs that qualify people to teach music in the compulsory schools in Norway. Five formalized educational paths were found, two of them clearly targeting the teacher profession $(1,2)$ and three targeting the professions of musicians or musicologists, including a practical-pedagogical study programme, 6o ECTS (PPU) $(3,4,5)$.

1. Specialist Music Teacher Education, [no: faglærerutdanning] (BA 3-4 years, 180/240 ECTS)

2. Generalist Teacher Education, [no: grunnskolelærerutdanning] (MA - 5 years, 300 ECTS in total, music: 30/60/135 ECTS)

3. Music Performance Education, [no: utøvende musikkutdanning] (BA - 3/4 years 180/240 ECTS) + PPU

4. Bachelor in Musicology, [no: BA i musikkvitenskap] (3 years, 180 ECTS) + PPU

5. 1-year Music course, [no: årsstudium i musikk], (60 ECTS) + PPU 
The mapping work also showed that the hours spent on principal instrument teaching in these programs were quite diverse (see appendix 3 for details). This might be obvious because the programs are differently targeted, but we were surprised to find huge differences also within the same educational programs in different institutions. To give an example: if a student chooses the second path, (2) GTE and the subject Music 1 (30 ECTS), only two out of eight institutions offer principal instrument lessons. If the student adds Music 2 (30 ECTS) for further specialization, three out of eight institutions offer lessons in principal instrument. However, this is not required to teach in primary and lower secondary schools in Norway. Some institutions also offer music as the master specialization subject (MA) in the GTE program. The table below shows the different music subjects or paths in the Generalist Teacher Education program in the different institutions and the total duration of principal instrument lessons that these programs offer.

Table 1 Principal instrument lessons in GTE

\begin{tabular}{|c|c|c|c|c|c|c|c|c|}
\hline Subject & OsloMet & NTNU & UiA & INN & USN & UiS & UiT & HVL \\
\hline Music 1 & $105 \mathrm{~min}$ & 0 min & $180 \mathrm{~min}$ & 0 min & $0 \mathrm{~min}$ & 0 min & $0 \mathrm{~min}$ & 0 min \\
\hline Music 2 & $105 \mathrm{~min}$ & $150 \mathrm{~min}$ & 0 min & 0 min & $0 \mathrm{~min}$ & 0 min & $0 \mathrm{~min}$ & $\begin{array}{l}360 \\
\min \end{array}$ \\
\hline MA & $0 \mathrm{~min}$ & $\begin{array}{l}450 \\
\mathrm{~min}\end{array}$ & $\begin{array}{l}\text { Not } \\
\text { offered }\end{array}$ & $\begin{array}{l}\text { Not } \\
\text { offered }\end{array}$ & $\begin{array}{l}\text { Not } \\
\text { offered }\end{array}$ & $\begin{array}{l}\text { Not } \\
\text { offered }\end{array}$ & $\begin{array}{l}\text { Not } \\
\text { offered }\end{array}$ & $0 \mathrm{~min}$ \\
\hline
\end{tabular}

If we focus solely on the subject Music 1, Norwegian University of Science and Technology (NTNU), Inland Norway University of Applied Sciences (INN), University of South-Eastern Norway (ISN), University of Stavanger (UiS), and Western Norway University of Applied Sciences (HVL) offer zero principal instrument lessons. However, if the student is enrolled at the University of Agder (UiA), he/she will get a total of 180 minutes of lessons spread out over two semesters. Oslo Metropolitan University (OsloMet) also offers a total of 105 minutes of principal instrument lessons within the subject Music 1.

The differences between the education programs are also remarkable in the first path, (1) Specialist Music Teacher Education. This program 
qualifies people for teaching music in Norwegian primary, lower, and upper secondary schools, and are located at different institutions; both earlier conservatories/music academies (UiA, NMH, UiT) and teacher educations (INN, Nord, HiVolda, HVL). The Norwegian Academy of Music (NMH) offer the most with a total of 65.25 hours of lessons on a principal instrument per student. In comparison, The Arctic University of Norway (UiT) which also offers a specialist program in music teaching, does not include principal instrument teaching.

Table 2 Principal instrument lessons in SMTE

\begin{tabular}{|l|c|c|c|c|c|c|c|}
\hline Institution & INN & Nord & UiA & HiVolda & NMH & HVL & UiT \\
\hline SMTE & $\begin{array}{c}2160 \\
\text { min }\end{array}$ & $\begin{array}{c}2160 \\
\text { min }\end{array}$ & $\begin{array}{c}2880 \\
\text { min }\end{array}$ & 810 min & $\begin{array}{c}3735 \\
\text { min }\end{array}$ & $\begin{array}{c}2160 \\
\text { min }\end{array}$ & 0 min \\
\hline
\end{tabular}

SMTE: Specialist Music Teacher Education

The studies in music performance, musicology, and the 1-year course in music are equally diverse in the amount of lessons provided on a principal instrument, but since these types of programs are not first and foremost music teacher education, we refer readers to appendix 3 for further details. $^{5}$

To summarize the findings: Although many of the aforementioned education programs provide qualifications for the same music teacher professions in primary and lower secondary schools, the differences between them are evident. These differences not only relate to the different programs but also to different institutions. Which university the students choose, therefore, determines if and how many lessons they will get on their principal instrument.

5 Students with education in music performance or musicology will, in either case, need PPU to become qualified to teach music from the 5 th grade and up. Fulfilled conservatory education or musicology, with PPU, does not qualify one to teach music in grades 1-4. 


\section{Analysis of the Reflection Texts}

As described, six reflection texts were gathered, three from educators in the generalist music teacher education program [no: grunnskolelærerutdanning] and three from educators in the specialist music teacher education program [no: faglærerutdanning]. The analytical work on these texts was geared towards describing the contexts and the educators' reoccurring themes about the principal instrument. In the following subsections, we first employ the reflection texts to describe these two types of education programs, (i) specialist music teacher education and (ii) generalist teacher education, and then we (iii) discuss the identified themes (subject-specific, human-specific, and learning-specific aspects) in relation to the concepts techné and deep learning.

\section{(i) Specialist Music Teacher Education}

Three of the reflection texts (E1, E2, E3) were from teachers in specialist music teacher education programs. The descriptions of the different educations show variations in the practice fields that the educations target; e.g. Nord University targets: primary, lower and upper secondary school and UiT targets primary and lower secondary school. In E1-E3's texts, the principal instrument seems emphasized not (only) as a main sole subject, but as a basis for other subjects, such as "music and communication" [no: musikkformidling] and "ensemble and leading" [no: samspill og ensembleledelse]. Specialized skill on one main instrument is explained in all three texts as a prerequisite to be able to play with others, perform for an audience, and conduct qualified and varied music lessons. Educator 3 describes this as follows:

Without skills on a principal instrument, I think the teacher will be poorer as a music-expert and will lack much insight into what it means to acquire a craft. These skills are transferable to other instruments and are absolutely fundamental to understanding what can be expected of a given group in specific situations. (Reflection text, E3)

Here, not only the specialized expertise but also the process of gaining expertise on a main instrument are emphasized as crucial in terms of becoming aware of future pupils' endeavors to take part in and perform 
music in given situations. The reflection texts from the teachers in this type of music teacher education program explain that the students learn several instruments and might change their choice of a principal instrument over the three-year educational program. Educator 2 sees this as problematic in relation to a continuous and deepening learning process:

This means that students cannot access deep learning on their instrument, which is required if you are to be able to develop and have a good and constructive process. (Reflection text, E2)

According to this educator, the students should stick to the same principal instrument throughout their whole education to ensure they experience a long-term, ever-deepening, and continuous learning process.

The three educators from the music-specific teacher education program all describe an educational culture in which the principal instrument is regarded as a cornerstone of their programs, and where there is a broad consensus that aspiring music teachers need specialized knowledge and skills on an instrument to learn about themselves as well as about music and teaching. Teacher E6's expressions (which has a background from both GTE and SMTE) undermines this and shows a reluctance towards E1-E3 description. E6 points to a culture where the principal instrument has not been emphasized. He explains a culture where to have competence on several instruments are seen as more important than having one dedicated principal instrument.

\section{(ii) Generalist Teacher Education}

Educators 4, 5, and 6 are teachers in the generalist teacher education program, which clearly targets the primary and lower secondary schools and qualifies the students to teach several subjects (for example, music and mathematics). In this program, all the students receive training in band playing and experience with band instruments, such as piano, guitar, bass and drums. This is explained by $\mathrm{E}_{4}$ and $\mathrm{E}_{5}$ as fundamental, and the band instruments are considered the most useful instruments through which to teach classroom music. E6 also points to that the relevance of a principal instrument in a classroom setting depends on which instrument the 
teacher or teacher student plays. The principal instrument is not emphasized in the same way as in the subject-specific music teacher education program, but the "skills to play" are highlighted as important in both E4's and E5's texts. E5 explains that:

... the skills to play are demanded in order to function as a music teacher in compulsory schools, both to play for and with the pupils, support their learning processes, understand music from a performer's perspective, and adjust the learning content/music according to the pupils and contexts. (Reflection text, E5)

However, music teacher students in these two generalist teacher education programs cannot necessarily choose the principal instrument that they know from before or want to learn. E4 writes that "the students have to choose either singing, guitar or piano," and E5 points out that the students can only choose a principal instrument that is offered by the teaching staff in the institution, and that the subject "principal instrument" occurs for the first time in the $4^{\text {th }}$ year of the education program.

The principal instrument is positioned in a different way in these reflection texts than in the texts from the educators in the music-specific teacher education program. $\mathrm{E}_{4}$ and $\mathrm{E}_{5}$ describe educational cultures in which the music educators agree that the student's skills to play and sing are fundamental, but that the instrumental training as well can happen on "useful" instruments for classroom teaching, such as guitar and piano.

\section{(iii) Principal Instrument - Art, Craft, and Deep Learning}

From the descriptions of the two types of music teacher education programs above, we now will discuss the three themes that reoccurred in the educators' reflection texts about the role of the principal instrument. These themes relate to the use of the principal instrument for (a) subject-specific concerns, (b) human-specific concerns, and (c) learning-specific concerns. These are discussed in the following paragraphs and elaborated in relation to this chapters theoretical premises.

A topic emphasized in all six reflection texts is that mastering an instrument is essential to understanding and being able to teach music. 
Even though the principal instrument is not the most weighted subject in the student's timetable, the ability to play for and with others is explained as a basis for understanding music as a subject, as well as an important area of learning. One educator explained that the principal instrument is the foundation for all music disciplines, such as music communication, choir, projects, concerts, and piano accompaniment (E3). These diverse musical disciplines and activities all include communication with others, and insights around finding and taking one's right place. For example, in a band setting, a musician's role is different when playing the bass or a percussion instrument or singing solo. The fundamental aspects of the music (steady rhythm, correct harmonical progression, etc.) need to work in order for the melody to be revealed or to support the soloist. Experience and security playing a principal instrument are fundamental to this. Primary school music teachers have been shown as especially vulnerable in relation to security and self-confidence in this area (Hennessy, 2000; Holden \& Button, 2006). From the six reflection texts in this study, the emphasis on skill with a principal instrument in the teacher education program is seen to contribute to a safe platform that reassures teachers of their musical skills. Thus, the subjectspecific explanations explicitly underline handicraft knowledge as crucial. This includes not only the technical skills to play an instrument, such as the ability to play both easy and advanced music and handle difficult passages, but also the musical sensitivity to create, perform, and be affected by musical expression. Handicraft, in this sense, refers not to the superficial skills necessary to produce music, but rather the insights into oneself as a player in relation to one or several music instruments and diverse pieces or styles of music. In mirroring these explanations to the Greek concept techné (Aristotle, 2011; Heidegger, 2006), handicraft concerns both art and craft as interdependent, in a form of knowing that is essential for musical creation and communication. Exactly this type of knowing might seem a prerequisite to operationalizing the subject of music in school as described in the curriculum (The Norwegian Directorate for Education and Training, 2019). In their reflections, all the educators underline that mastering an instrument is the basis of knowledge for teaching music in school - not only for their own confidence and 
musical knowledge - but also to facilitate their pupils' learning paths. Music teachers are viewed as requiring the ability to play both with and for their students, which is a basic part of their role. As E1 writes, "Without mastering an instrument, they would become 'fake' music teachers," and thus this ability relates to their trustworthiness, knowledge, and responsibility as music teachers. Several of the educators point to the fact that many music teachers in primary and secondary schools in Norway have no formal music education and emphasize the importance of music teachers knowing how to play an instrument and sing. Although there were variations between the generalist teacher educators and the specialist music educators regarding their view on what instrument the students should choose (most useful in classroom or freely chosen with reference to previous music education or other preferences), all six point to the process of learning an instrument as crucial and beneficial to teaching music, regardless of the instrument.

Closely interrelated with the subject-specific theme are the reoccurring explanations of skill with a principal instrument as an area that expands one's insights in terms of identity, personality, and human relations. This concerns the students' gradual development of a music teacher identity, as well as their abilities to understand and support the learning processes of their future pupils. Earlier studies point to a lack of confidence as a problem for primary school music teachers without specialized musical knowledge (e.g., Hennessy, 2000; de Vries, 2015). Similarly, it can be said that a lack in special competence in playing and singing contributes to a lack of perspective about the relation between the music teacher and the pupil, as well as in relation to the common references of musical works and to the characteristics of being a music teacher. Dobrowen (2020) describes being a music teacher in primary school as a "lonely professionality", and this might be encompassed and broadened, progressing from the educators' reflections in this study. For example, learning an instrument through long-term effort can be related to learning about people, something that is common to teachers in all subjects in school. Knowing a principal instrument is explained as important both for meeting and dealing with the various pupils and groups that music teachers encounter in school, and also for differentiating for the learners the learning content 
(what is meant to be played or sung) and the musical progression. To have experienced the same process as the pupils are engaged in is described by E3 as fundamental to gaining perspective on each pupil's level, prospects, and paths. E1 states this as crucial in gaining respect from prospective pupils, as well as having respect for the handicraft and subject of music itself. Sennet (2008, p. 65) points to how the knowledge to make something exists in both the hand and the head, as well as in the heart, and warns against making a separation between "arts" and "craft," as these are seen as two sides of the same coin. Techné-knowledge, as explained by Heidegger (2006), goes even deeper and suggests that the ability to create something is a way of knowing that is essential for humans. Learning a handicraft, as a principal instrument, is a quality-driven process, aiming for unique expression as well as good relationships - for example, in a musical context as a choir or a band. The six educators' pinpointing of the "identity" aspects related to mastering an instrument at the advanced levels might also be deepened through Nielsen's elaboration of the musical work and its correspondence with human consciousness on different levels (Nielsen, 1998, pp. 137-139). The innermost layers in music are here explained as existentially oriented, connected to an awareness of what it is to be a human, and what reality is or should be. Even though the principal instrument, especially in the music-specific program (ii), seems to be taught through one-to-one lessons, all six educators point out that an important aspect is the ability to play with and for others. This points to a relational understanding of music and to the notion of music as something that one does together with others. In Small's theories about music as "musicking," these perspectives on music are fundamental. Here, musical works and individual mastery are subordinated to the musical activities' potential for revealing the "relationships between person and person, between individual and society, between humanity and the natural world and even perhaps the supernatural world" (Small, 1998, p. 13). From this perspective, promoting the role of the principal instrument in music teacher education could serve as a human-oriented approach that not only considers individual music teachers and their qualified abilities to perform and experience music, but also facilitates and advances musical expressions and engagements with groups and societies. 
Most of the educators (E1-E5) emphasize the principal instrument with regard to the process and quality of learning, whereas E6 is using more general terms; e.g. "principal instrument certainly has a value in itself". E3 states that "there is no 'quick fix'?" and explains how the thorough process of learning an instrument demands patience and endurance and provides insight into the gaining of knowledge that facilitates the learning processes in all school subjects. This explanation is hardly distinguishable from how deep learning is described in the educational literature, research, and curricula (e.g., Fullan et al., 2018, 2013). Deep learning is explained as "meaningful" (Ferm \& Johansen, 2008) in that it involves character, self-understanding, and subject knowledge in engaging with the same learning content and learning activities over an extended time (Fullan et al., 2018). Approaches to learning that aim for deep understandings of subject knowledge, connections between subjects, and an understanding of humans, cultures, and societies are portrayed with the same thorough and passionate approach that the six educators employ in their reflections on the place of the principal instrument in music teacher education. The contradiction to deep learning is often articulated as superficial learning, which refers to how learners in today's society can access all kinds of information rapidly, with minimal effort and engagement. However, to support more engaged, healthy, and visionary individuals, experiences with deep learning processes are seen as vital (Fullan et al., 2018; Østern et al., 2019). Three of the educators in this study warn against giving the students possibilities to constantly change their principal instrument (for example, from drums to piano), because this threatens the student's experiences with long-time processes and deep learning. Even though classroom music teaching demands skills on different and specific instruments (e.g., piano, guitar, song), the process of "learning how to learn" $\left(E_{3}, E_{1}\right)$ is best achieved on the same instrument throughout one's whole education. From this; fundamental learning, skills on other instruments and in different musical styles can be gained more superficially, but a specialization on a principal instrument may lead to a deeper understanding of music, craftsmanship, and human relations.

Together, these three themes suggest a discussion about what kind of subject music should be, both in schools and in music teacher education 
programs. From the educators' reflections in this study, discussed with reference to the concept of techné (Heidegger, 2006; Varkøy et al., 2020), deep learning (Fullan et al., 2018; Østern et al., 2019), and craftmanship (as explained by Sennet, 2008), the principal instrument can be seen to nurture many kinds of knowledge and various ways of knowing, based on the notion of music as a primarily practical and aesthetic subject. The principal instrument is seen as necessary in the development of music teachers, regarding their knowledge, skills, identity, and character, and as a unique means for learning how to learn and relate to different persons and groups.

\section{Concluding Remarks}

The research question for our study was: How is the principal instrument emphasized in music teacher educations in Norway? The mapping of the diverse music teacher education programs shows great variation in whether and how a principal instrument is prioritized in the different programs, as well as between institutions that offer the same programs. The institutional emphasis towards principal instrument instruction, reflected in the course plans and timetables of specialist music teacher education and generalist music teacher education program, varies between 0 and $3735 \mathrm{~min}$. Educators E1-E5 in this study emphasize the principal instrument as crucial to (i) develop broad and deep knowledge and specialized skills in music (subject-specific), (ii) develop broad and deep knowledge to meet diverse pupils as individuals and groups, as well as insight into oneself and the development of a secure and robust music teacher identity (human-specific), and (iii) to "learn to learn" (learningspecific). Their emphasis of a principal instrument in music teacher education intersects the division between arts and crafts, and positions skill with an instrument as crucial for both music-specific knowledge and for knowledge about learning and teaching that is needed to work as and, perhaps equally important, to be a music teacher.

The content, forms, and aims in music teacher education are the topics of ongoing discussions in the international field of music education research (e.g., Angelo et al., 2021; Bowman, 2007; Kaschub et al., 2014). A 
central topic in these debates is the tension regarding specialists or generalists as best suited to teach music in primary and secondary schools (e.g., de Vries, 2015; Holden \& Button, 2006; Wiggins \& Wiggins, 2008). In these discussions, the place and weight put on learning a principal instrument are vital. Traditionally, the handicraft to play one or several music instruments has been a cornerstone of music education and in music teacher education. As mentioned in the introduction, the impact of music technology is bringing new perspectives to this view and the students may well be taught their principal instrument by their "virtual craft guild", e.g. via YouTube. Regardless, this study reveals great variations between educational programs as well as between different institutions in terms of the time spent learning a principal instrument. A main question after this examination is: what is the time and effort spent, in music teacher education when it is not given to playing and singing? This question needs follow-up studies to be answered. Still, earlier studies on higher education in general, as well as on higher education in music, point to how the processes of academization have heavily influenced how time is spent in higher education for many vocations and professions (Angelo et al., 2019; Gies, 2019; Messel \& Smeby, 2017; Wolter \& Kerst, 2015). The music teacher students in GMTE, SMTE and PPU programs in this study are expected to write bachelor's and master's theses (or similar) and to engage in research-informed literature about music and education. ${ }^{6}$ This might increase future music teachers' critical reflections on music and education and perhaps strengthen the place of music in the educational systems, but it is also a time- and effort-consuming path that might challenge the time for learning music-specific skills and mastery. Although subject-specific skills can be seen to discredit a pedagogical competence to equalize with students, and to remove the fear of failure (Lindgren $\&$ Ericsson, 2011), there are good reasons to question the lack of skills to play and sing among music teachers in schools. In 2019, around 60\% of the teachers that teach music in primary and secondary schools in Norway

6 see e.g. regulations relating to the framework plan for primary and lower secondary education (Ministry of education and Research, 2016a, 2016b), and National Curriculum Regulations for Teacher Education in Practical and Aesthetic Subjects for Years 1-13 (Ministry of Education and Research, 2020). 
had no formal music education (Statistisk sentralbyrå, 2019). From this study, the ability to play an instrument for and with the pupils can also be questioned with regard to the $40 \%$ of the teachers that actually have music as part of their education. According to the discussions in this chapter, the curriculum's emphasis on deep learning and the portrayal of music as a practical subject with the power to urge creativity and experimentation can be seen as thoroughly enabled through the time and effort spent on learning a principal instrument in music teacher education programs.

In this study, learning and practicing a principal instrument is expounded as providing thorough understandings and critical insights related to the subject of music, to the essence of being human, and to the deep processes of learning through long-time study, with constant examination of the connection of previous knowledge to the learning process. In this regard, the principal instrument can be seen as occupying a valuable place in music teacher education programs that combine arts, crafts, and deep learning. Thus, it can provide future music teachers with the artistic sensitivity to better grasp diverse expressions, and, intertwined with their technical knowledge, the enhanced skill to make and form unique expressions. Indeed, without this ability, words such as creating, experimenting, and exploring might seem unqualified, empty, and utopian.

The students referred to at the beginning of this chapter discussed whether specialized or generalized musical knowledge was most important in becoming a school music teacher. This spurred our curiosity and demanded a deeper discussion about what content and activities are seen, and should be seen, as central in music teacher education. Through explicating the potentials of techné, arts, and crafts in relation to deep learning processes, this study gives music teachers and music teacher educators a perspective for viewing the specialization on a main instrument as general education, with processes that provide insights on learning how to learn. This also intersects the division found in music education research between supporting students' general growth and well-being and developing their music-specific knowledge and skills. Instead of discussing the craftsmanship that disappeared, this provides us with a perspective to argue for the craftsmanship to reappear in music teacher education that qualifies people to teach music as one or several subjects in school. 


\section{References}

Angelo, E., Varkøy, Ø., \& Georgii-Hemming, E. (2019). Notions of mandate, knowledge and research in Norwegian classical music performance studies. Journal for Research in Arts and Sports Education, Special Issue: Community Arts/ Arts Education, 3(1), 78-10o. http://dx.doi.org/10.23865/jased.v3.1284

Angelo, E., Knigge, J., Sæther, M., \& Waagen, W. (2021). The discursive terms of music/teacher education at four higher educational institutions. In E. Angelo, J. Knigge, M. Sæther, \& W. Waagen (Eds.), Higher education as context for music pedagogy research (pp. 351-386). Cappelen Damm Akademisk.

Aharony, N. (2006). The use of deep and surface learning strategies among students learning English as a foreign language in an internet environment. British Journal of Educational Psychology, 76(4), 851-866. http://dx.doi. org/10.1348/000709905X79158

Aristotle (2011). Aristotle's Nicomachean ethics. The University of Chicago Press.

Bandlien, B.-T. (2019). Ungdomskoleelevers komponering med GarageBand på iPad:

En musikkdidaktisk studie av performative stopp-punkter $i$ et kritisk designteoretisk perspektiv [Secondary school pupils composing with Garageband on iPad: A music educational study of performative stop-moments in a critical design theoretical perspective]. [Doctoral dissertation, Norwegian University of Science and Technology]. http://hdl.handle.net/11250/2643673

Benedict, C., \& Schmidt, P. (2014). Education teachers for the $21^{\text {st }}$-century challenges: The music educator as a cultural citizen. In M. Kaschub \& J. Smith (Eds.), Promising practices in 21st century music teacher education (pp. 79-99). Oxford University Press.

Biggs, J. (1999). What the student does. Higher Education Research and Development, 18, 57-75. http://dx.doi.org/10.1080/0729436990180105

Biggs, J. (2004). Teaching for quality learning at university: What the student does. Philadelphia Open University Press.

Bowman, W. (2007). Who is the "we"? Rethinking professionalism in music education. Action, Criticism and Theory for Music Education, 6(4), 109-131.

Braun, V., \& Clarke, V. (2006). Using thematic analysis in psychology. Qualitative Research in Psychology, 3(2), 77-101. http://dx.doi.org/10.1191/1478088706qpo63oa

Creswell, J., \& Creswell, D (2018). Research design - qualitative, quantitative, and mixed methods approaches. Sage.

Daniel, R., \& Parkes, K., A. (2017). Music instrument teachers in higher education: An investigation of the key influences on how they teach in the studio. International Journal of Teaching and Learning in Higher Education, 29(1), 33-46. http://www.isetl.org/ijtlhe/pdf/IJTLHE2387.pdf 
de Vries, P. (2013). Generalist teachers' self-efficacy in primary school music teaching. Music Education Research, 15(4), 375-391. https://doi.org/10.1080/146138 08.2013.829427

de Vries, P. (2015). Music without a music specialist: A primary school story. International Journal of Music Education, 33(2), 210-221. https://doi. org/10.1177/0255761413515818

Dobrowen, L. (2020). Musikk på barnetrinnet. En studie av loereres forståelser av profesjona litet i musikkundervisning [Music in primary school. A study of teachers' ways of understanding professionalism in music teaching]. [Doctoral dissertation, Norwegian Academy of Music]. https://hdl.handle.net/11250/2672795

Eiksund, Ø. J., \& Reistadbakk, E. (2020). Knowledge for the future music teacher: Authentic learning spaces for teaching songwriting and production using music technology. In Ø. J. Eiksund, E. Angelo, \& J. Knigge (Eds.), Music technology in education - channeling and challenging perspectives (pp. 181-210). Cappelen Damm Akademisk.

Ferm, C., \& Johansen, G. (2008). Professors' and trainees' perceptions of educational quality as related to preconditions of deep learning in musikdidaktik. British Journal of Music Education, 25(2), 177-191. https://doi.org/10.1017/ So265051708007912

Filius, Renée M., de Kleijn, Renske A. M., Uijl, Sabine G., Prins, Frans J., van Rijen, Harold V. M., \& Grobbee, Diederick E. (2018). Promoting deep learning through online feedback in SPOCs. Frontline Learning Research, 6(2) 92-113.

Fredriksen, B. (2018). Leaving the music classroom. A study of attrition from music teaching in norwegian compulsory schools. [Doctoral dissertation, Norwegian Academy of Music]. https://nmh.brage.unit.no/nmh-xmlui/handle/11250/2502217

Fullan, M., \& Langworthy, M. (2013). Towards a new end: New pedagogies for deep learning. Collaborative Impact.

Fullan, M., Quinn, J., \& McEachen, J. (2018) Deep learning: Engage the world change the world. Corwin.

Garrison, D. R., Anderson, T., \& Archer, W. (2001). Critical thinking, cognitive presence, and computer conferencing in distance education. American Journal of Distance Education, 15(1), 7-23, https://doi.org/10.1080/08923640109527071

Georgii-Hemming, E., \& Westvall, M. (2010). Music education-a personal matter? Examining the current discourses of music education in Sweden. British Journal of Music Education, 27(1), 21-33.

Gies, S. (2019). How music performance education became academic. On the history of higher music education in Europe. In S. Gies \& J. H. Sætre (Eds), Becoming musicians - student involvement and teacher collaboration in higher music education (pp. 31-52). The Norwegian Academy of Music. 
Hall, M., Ramsay, A., \& Raven, J. (2004). Changing the learning environment to promote deep learning approaches in first-year accounting students. Accounting Education, 13(4), 489-505. https://doi.org/10.1080/0963928042000306837

Hay, D. B. (2007). Using concept maps to measure deep, surface and nonlearning outcomes. Studies in Higher Education, 32(1), 39-57. https://doi. org/10.1080/03075070601099432

Heidegger, M. (2006). The origin of the work of the art. Translated by R. Berkowitz and P. Nonet. academia.edu/2083177/Bard College

Hennessy, S. (2000). Overcoming the red-feeling: The development of confidence to teach music in primary school amongst student teachers. British Journal of Music Education, 17(2), 183-96.

Holden, H., \& Button, S. (2006). The teaching of music in the primary school by the non-music specialist. British Journal of Music Education, 23(1), 23-38.

Holgersen, S.-E., \& Holst, F. (Eds.) (2020). Musikfaget i undervisning og uddannelse. Status og perspektiv 2020 [The music subject in teaching and education. Status and perspectives 2020]. Danmarks Institut for Pædagogik og Uddannelse, Aarhus Universitet. https://edu.au.dk/fileadmin/edu/Udgivelser/Rapporter/Rapport_-_ Musikfaget_i_undervisning_og_uddannelse_2020.pdf

Johansen, G. (2007). Educational quality in music teacher education. Components of a foundation for research. Music Education Research, 9(3), 435-448.

Kaschub, M., \& Smith, J. (Eds.) (2014). Promising practices in 21st century music teacher education. Oxford University Press.

Lindgren, M., \& Ericsson, C. (2011). Arts education in Swedish teacher training what's at stake? Australian Journal of Teacher Education, 36(8), 18-31. https:// ro.ecu.edu.au/ajte/vol36/iss8/2/

Marton, F., \& Säljö, R. (1976). On qualitative differences in learning: I--Outcome and process. British Journal of Educational Psychology, 46(1), 4-11. https://doi. org/10.1111/j.2044-8279.1976.tbo2980.x

Messel, J., \& Smeby, J.-C. (2017). Akademisering av høyskoleutdanningene? [Academizaton of the college universities?]. In S. Mausethagen \& J.-C. Smeby (Eds.), Kvalifisering til profesjonell yrkesutøvelse [Qualification for professional occupational practice] (pp. 44-56). Universitetsforlaget.

Ministry of Education and Research. (2016a). Regulations relating to the framework plan for primary and lower secondary teacher education for years 1-7. (FOR-2016-06-07-860). https://www.regjeringen.no/contentassets/ c454dbe313c1438b9a965e84cec47364/forskrift-om-rammeplan-forgrunnskolelarerutdanning-for-trinn-1-7---engelsk-oversettelse-11064431.pdf

Ministry of Education and Research. (2016b). Regulations relating to the framework plan for primary and lower secondary teacher education for years 5-10. (FOR-2016-06-07-861). https://www.regjeringen.no/conten 
tassets/c454dbe313c1438b9a965e84cec47364/forskrift-om-rammeplan-forgrunnskolelarerutdanning-for-trinn-5-10---engelsk-oversettelse.pdf

Ministry of Education and Research. (2017). Core curriculum - values and principles for primary and secondary education. https://www.udir.no/Udir/ PrintPageAsPdfService.ashx?pdfld=150459

Ministry of Education and Research. (2020). National curriculum regulations for teacher education in practical and aesthetic subjects for years 1-13. (FOR-2020-0604-1134). https://lovdata.no/dokument/SF/forskrift/2020-06-04-1134

NESH (2016). Forskningsetiske retningslinjer for samfunnsvitenskap, humaniora, juss og teologi [Guidelines for research ethics in the social sciences, humanities, law and technology]. Den nasjonale forskningsetiske komité for samfunnsfag og humaniora (NESH). https://www.etikkom.no/forskningsetiske-retningslinjer/ Samfunnsvitenskap-jus-og-humaniora/

Nielsen, F. V. (1998). Almen musikdidaktik [General music didactics] (2nd ed.). Christian Ejler.

The Norwegian Directorate for Education and Training. (2019). Curriculum in music. https://data.udir.no/klo6/v201906/laereplaner-lk2o/MUSo1-02.pdf

NOU 2015: 8 (2015). Fremtidens skole. Fornyelse av fag og kompetanser. [The school for the future. The renewal of subjects and competences]. Ministry of Education and Research. https://www.regjeringen.no/contentassets/ da148fec8c4a4ab88daa8b677a700292/no/pdfs/nou2015201500080oodddpdfs.pdf

Rillero, P. (2016). Deep conceptual learning in science and mathematics: Perspectives of teachers and administrators. Electronic Journal of Science Education, 2o(2), 14-31.

Ruddock, E., \& Leong, S. (2005). 'I am unmusical!': The verdict of selfjudgement. International Journal of Music Education, 23(9) 9-22. https://doi. org/10.1177\%2Fo255761405050927

Russell-Bowie, D. (2009). What me? Teach music to my primary class? Challenges to teaching music in primary schools in five countries. Music Education Research, 11(1), 23-36. https://doi.org/10.1080/14613800802699549

Seddon, F. \& Biasutti, M. (2008). Non-music specialist trainee primary school teachers' confidence in teaching music in the classroom. Music Education Research, 10(3), 403-421. https://doi.org/10.1080/14613800802280159

Sennet, R. (2008). The craftsman. Penguin Books Ltd.

Small, C. (1998). Musicking: The meanings of performing and listening. University Press of New England.

Statistisk sentralbyrå. (2019). Lorerkompetanse i grunnskolen [Teacher competence in the primary and lower secondary school]. https://www.ssb.no/utdanning/ artikler-og-publikasjoner/laererkompetanse-i-grunnskolen--390746 
Sætre, J. H. (2014). Preparing generalist student teachers to teach music: A mixedmethods study of teacher educators and educational content in generalist teacher education music courses. [Doctoral dissertation, Norwegian Academy of Music] http://hdl.handle.net/11250/226772

Sætre, J. H. (2018). Why school music teachers teach the way they do: A search for statistical regularities. Music Education Research, 20(5), 546-559. https://doi.org/1 $0.1080 / 14613808.2018 .1433149$

Sætre, J. H., Ophus, T., \& Neby, T. B. (2016). Musikkfaget i norsk grunnskole: Læreres kompetanse og valg av undervisningsinnhold musikk. [The music subject in the Norwegian primary and lower secondary school: The teachers' competence and their choice of educational content]. Acta Didactica Norge, 10(3), 1-18. https://doi.org/10.5617/adno.2876

Varkøy, Ø., Angelo, E., \& Rolle, C. (2020). Artist or crafts(wo)man? European Journal of Philosophy in Arts Education, 5(1), 7-32. https://doi.org/10.5281/ ZENODO.3940997

Wiggins, R. A., \& Wiggins, J. (2008). Primary music education in the absence of specialists. International Journal of Education and the Arts, 9(12). http://www.ijea. org/v9n12/

Wolter, A., \& Kerst, C. (2015). The 'academization' of the German qualification system: Recent developments in the relationships between vocational training and higher education in Germany. Research in Comparative and International Education, 10(4), 510-524.

Østern, T. P., Dahl, T., Strømme, A., Petersen, J. A., Østern, A.-L., \& Selander, S. (2019). Dybde//loering - en flerfaglig, relasjonell og skapende tilnorming [Deep education a cross-curricular, relational and artful approach]. Universitetsforlaget. 


\section{Appendix 1}

Fra: Fritz Flåmo Eidsvaag fritz.f.eidsvaag@ntnu.no

Emne: Hovedinstrumenttimer i musikklærerutdanning.

Dato: 11. desember $2018 \mathrm{kl}$. 10:47

Til:

Hei!

Jeg er med i en forskningsgruppe som heter Musikklærerutdanning i utvikling_(MiU). og jobber i den forbindelse med en kartlegging av de ulike veiene for å bli musikklærer i grunnskolen. Jeg ser spesielt på hvor mange timer hovedinstrumentundervisning (antall og varighet) den enkelte ferdig utdannede grunnskolelærer har fått gjennom studieløpet. I den forbindelse lurer jeg på om du kan sende meg en enkel oversikt over antall hovedinstrumenttimer som tilbys i de ulike utdanningsveiene deres og som kvalifiserer til å undervise i grunnskolen (eventuelt ved å ta PPU i tillegg). For studenter ved_lal sin del vil vel dette dreie seg om de som går MGLU med Musikk 1 og eventuelt Musikk 2 om jeg ikke tar helt feil.

Studien vil publiseres som en vitenskapelig artikkel i Open Access-antologien Musikklærerutdanning i utvikling (Universitetsforlaget, red: Angelo, Knigge, Waagen, Sæther), høsten 2020.

$\mathrm{mvh}$

Fritz Flåmo Eidsvaag

Universitetslektor i musikk

Institutt for lærerutdanning, NTNU

TIf. 734128 31/ Mobil 41411831

\section{Appendix 2}

Fra: Fritz Flåmo Eidsvaag fritz.f.eidsvaag@ntnu.no

Emne:

Dato: 8. februar 2020 kl. 11:04

$\mathrm{Til}$

Hei

Jeg er med i en forskningsgruppe som heter Musikklærerutdanning i utvikling (MiU) og jobber i den forbindelse med en kartlegging av de ulike veiene for å bli musikklærer i grunnskolen. Jeg ser spesielt på hvor mange timer hovedinstrumentundervisning (antall og varighet) den enkelte ferdig utdannede grunnskolelærer har fått gjennom studieløpet og den forbindelse ønsker jeg og medforfatter Elin Angelo å intervjue et par ansatte ved ulike musikklærerutdannninger angående dette temaet. Spørsmålene er formulert slik:

"Vi ber deg i dette skrivet om å reflektere rundt hovedinstrumentets plass i musikklærerutdanning på din institusjon.

1. Hvordan opplever du at hovedinstrumentet er vektlagt i musikklærerutdanningen hos dere?

2. Er det tradisjonelt slik at dine studenter jobber i grunnskolen som musikklærere når de er ferdig utdannet? Beskriv.

3. På hvilke måter trengs hovedinstrumentkunnskap/-ferdigheter hos musikklærere i grunnskolen?

4. Beskriv kulturen for (og forhandlinger/meninger om) hovedinstrumentundervisning på din institusjon.»

Intervjuet vil være fullt anonymisert, både i forhold til personopplysninger og institusjon.

Studien vil publiseres som en vitenskapelig artikkel i Open Access-antologien Musikklærerutdanning i utvikling (Universitetsforlaget, red: Angelo, Knigge, Waagen, Sæther), høsten 2020.

Mvh Fritz 


\section{Appendix 3}

Table of principal instrument teaching in education programs qualifying for music teaching in primary and lower secondary school in Norway. "Semester in total" means how many semesters with principal instrument lessons.

\begin{tabular}{|c|c|c|c|c|}
\hline $\begin{array}{l}\text { Specialist } \\
\text { teacher } \\
\text { education }\end{array}$ & Musicology & Music performance & $\begin{array}{l}\text { One-year music } \\
\text { course }\end{array}$ & $\begin{array}{l}\text { Generalist } \\
\text { teacher } \\
\text { education }\end{array}$ \\
\hline $\begin{array}{l}\text { INN: } 36 \\
\text { lessons of } \\
60 \text { min, } \\
\text { ( } 6 \text { semesters } \\
\text { in total) }\end{array}$ & $\begin{array}{l}\text { UiO: Bachelor: } \\
8 \text { lessons } \\
\text { of } 45 \text { min } \\
\text { (compulsory) } \\
2 \text { elective } \\
\text { courses, each } \\
\text { one with } 8 \\
\text { lessons of } \\
45 \text { min. } \\
\text { MA: } 24 \text { lessons } \\
\text { of } 45 \text { min } \\
\text { (elective) }\end{array}$ & $\begin{array}{l}\text { Barratt Due: } \\
\text { BA: } \\
120 \text { lessons of } 60 \mathrm{~min} \\
+14 \text { lessons } \\
\text { W/accompanist } \\
\text { MA: } \\
48 \text { lessons of } 60 \mathrm{~min}\end{array}$ & $\begin{array}{l}\text { NTNU: } \\
25 \text { lessons } \\
\text { ( } 2 \text { semesters in } \\
\text { total) } \\
\text { One-year study } \\
\text { in church music: } \\
27 \text { lessons } \\
\text { ( } 2 \text { semesters in } \\
\text { total) }\end{array}$ & $\begin{array}{l}\text { OsloMet: } \\
\text { Music 1: } 7 \\
\text { lessons of } \\
15 \text { min } \\
\text { Music } 2: 7 \\
\text { lessons of } \\
15 \text { min } \\
\text { MA: } 0 \text { min }\end{array}$ \\
\hline UiT: 0 min & $\begin{array}{l}\text { NTNU: } \\
\text { BA: } 37 \text { lessons } \\
\text { (3 semesters). } \\
\text { MA: } 25 \text { lessons } \\
\text { (2 semesters) }\end{array}$ & $\begin{array}{l}\text { UiT: } \\
\text { BA: } 104 \text { lessons of } \\
45 \text { min. ( } 8 \text { semesters } \\
\text { in total) }\end{array}$ & HVL: 13 lessons & $\begin{array}{l}\text { NTNU: } \\
\text { Music 1: } 0 \\
\text { lessons } \\
\text { Music } 2: 5 \\
\text { lessons of } 30 \text { min } \\
\text { (1 semester in } \\
\text { total) } \\
\text { MA: } 450 \text { min }\end{array}$ \\
\hline $\begin{array}{l}\text { HVL: } \\
\text { Specialist } \\
\text { T. E.: } 48 \\
\text { lessons of } \\
45 \text { min } \\
\text { ( } 6 \text { semesters } \\
\text { in total)/ } \\
\text { Community } \\
\text { music: } 42 \\
\text { lessons of } \\
45 \text { min. ( } 6 \\
\text { semesters in } \\
\text { total). }\end{array}$ & $\begin{array}{l}\text { UiB: elective } \\
\text { course w/ } \\
\text { admission test } \\
10-12 \text { lessons }\end{array}$ & $\begin{array}{l}\text { NMH: } \\
\text { BA: } \\
\text { Classical: } 116 \text { of } \\
60 \text { min. ( } 8 \text { semesters } \\
\text { in total), } \\
\text { Jazz: } 104 \text { lessons of } \\
60 \text { min ( } 8 \text { semesters } \\
\text { in total) } \\
\text { Folk music: } 135 \\
\text { lessons of } 75 \text { min } \\
\text { ( } 8 \text { semesters in total) } \\
\text { Church music: } 116 \\
\text { lessons of } 60 \text { min } \\
\text { ( } 8 \text { semesters in total }\end{array}$ & $\begin{array}{l}\text { Hiø: not } \\
\text { specified }\end{array}$ & $\begin{array}{l}\text { UiA: } \\
\text { Music 1: } 8 \\
\text { lessons of } \\
22,5 \text { min } \\
\text { ( } 2 \text { semesters in } \\
\text { total) }\end{array}$ \\
\hline $\begin{array}{l}\text { UiA: } 64 \\
\text { lessons of } \\
45 \text { min ( } 8 \\
\text { semesters in } \\
\text { total) }\end{array}$ & & & & $\begin{array}{l}\text { INN: } \\
\text { Music 1: } 0 \\
\text { lessons } \\
\text { Music 2: } 0 \\
\text { lessons }\end{array}$ \\
\hline
\end{tabular}




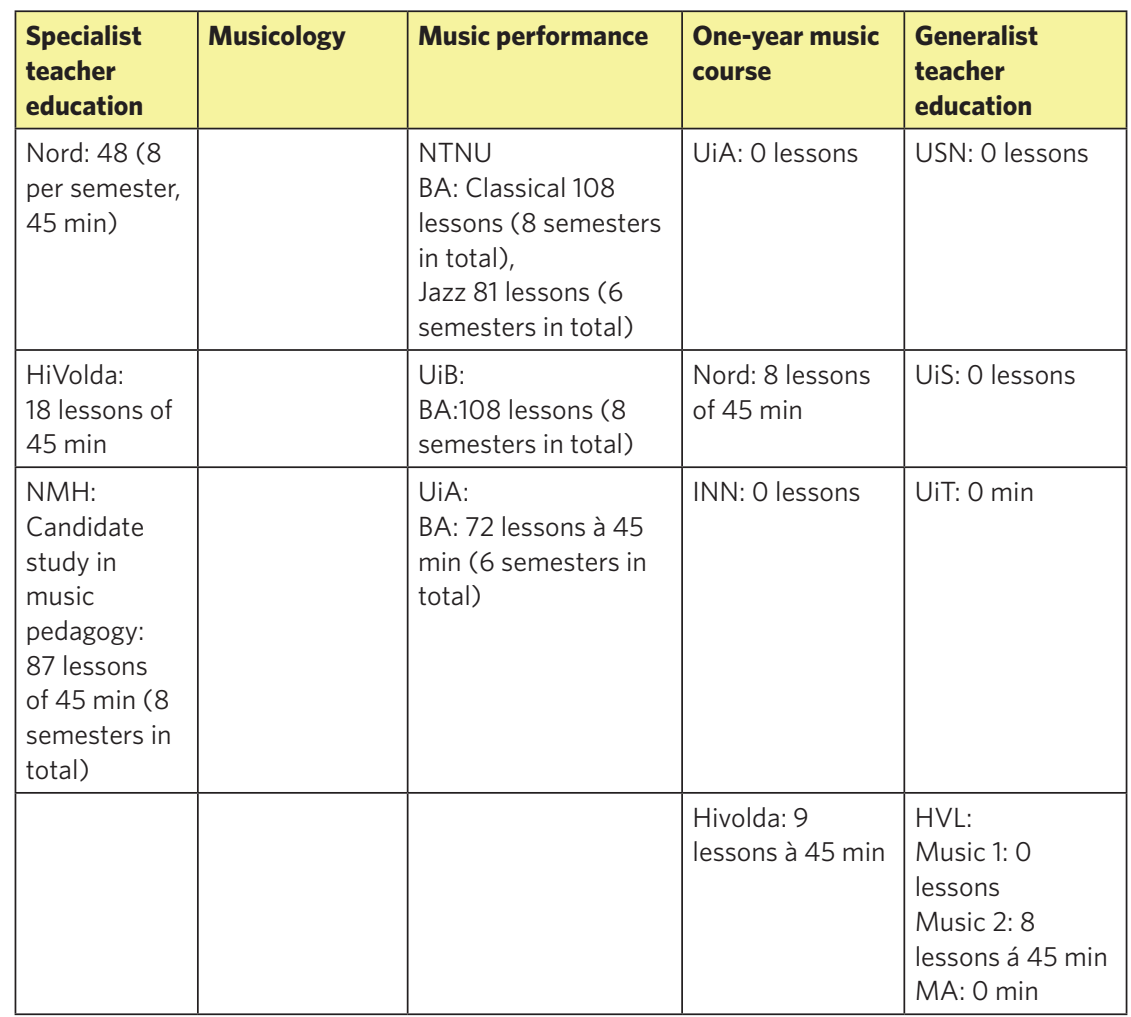

INN: Inland Norway University of Applied Sciences

UiT: The Arctic University of Norway

HVL: Western Norway University of Applied Sciences

UiA: University of Agder

HiVOIda: Volda University College

UiO: University of Oslo

UiB: University of Bergen

UiS: University of Stavanger

$\mathrm{NMH}$ : Norwegian Academy of Music

NTNU: Norwegian University of Science and Technology

HiØ: Østfold University College

USN: University of South-Eastern Norway

OsloMet: Oslo Metropolitan University

Nord: Nord University 


\title{
Can We Buy Virtue? Implications from State University Funding On Musical Instrument Performance Teacher Mandate
}

\author{
Robin Rolfhamre \\ University of Agder
}

\begin{abstract}
Recent world developments have put a strain on the humanities in general, and higher education music performance study degree-programmes in particular. In an educational system currently promoting consumer-product relationships where the music performance teacher is very much accountable for the students' development into professional musicians and, recently, also sustainable world citizens, we must give more attention to what, whom and why we educate? This chapter is an armchair analytical philosophical continuation of a paper published elsewhere (Rolfhamre, 2020). Taking the lead from Julia Annas' (2011) virtueas-skill, I will, here, elaborate on what implications the Norwegian state higher education funding system may have on the higher education music performance teacher's perceived mandate from the perspectives of music pedagogy, rhetoric and virtue ethics. First, I pursue three different usages of the verb "to buy" to exemplify why I find the chapter's title to be relevant and valid. This sets the premises for the following turn to rhetoric to highlight the starting point's persuasive functions and incentives. Subsequently, I briefly relate the argument to Butlerian performativity to emphasise its relation to normativity, inclusion-exclusion and the theoretical possibility of "breaking free". From this position, I draw on Aristotelian phronesis, mainly through the position held by Hansen (2007) to sketch up an ecology in which I ask how this all affects the teacher's mandate?
\end{abstract}

Keywords: higher education, music performance, teacher's mandate, virtue, rhetoric, pedagogy

Citation of this chapter: Rolfhamre, R. (2021). Can We Buy Virtue? Implications from State University Funding On Musical Instrument Performance Teacher Mandate. In E. Angelo, J. Knigge, M. Sæther \& W. Waagen (Eds.), Higher Education as Context for Music Pedagogy Research (pp. 95-112). Cappelen Damm Akademisk. https://doi.org/10.23865/noasp.119.ch4

License: CC BY-NC-ND 4.0. 
Recent world developments have put a strain on the humanities in general as neoliberalist policies, and new public management incentives result in the education of ethical values (such as compassion and morality) becoming somewhat secondary to economic growth and value creation (Nussbaum, 2010). The UN's blueprint, sustainability goals to "achieve a better and more sustainable future for all" clearly put an expectation on the world's nations to deliver results. "[I]n order to leave no one behind, [they have it,] it is important that we achieve them all [i.e. all defined goals] by 2030" (United Nations, 2020), and, as the common metaphorical expressions have it: "time is money", "time is of the essence". The Norwegian state, for instance, is obligated to contribute to realising these goals and, naturally, impose on all state-funded operations and institutions to act and produce accordingly. The national education curriculum, at all levels, are no exception (Regjeringen, 2020a, 2020b, 2020c; Rolfhamre, 2020; United Nations, 2020; Utdanningsdirektoratet, 2020). When the Norwegian state further defines itself as a "knowledge economy" (Kunnskapsdepartementet, 2016), we begin to understand that there are pressing matters here to discuss concerning the future of music performance from the perspective of recruiting, educating and sustaining a traditional craft professionally and what function we, as teachers, will end up having down the road. To give the following argument here some sort of focus, I will theorise within the domains of the Norwegian state in general and the Norwegian state higher education in particular, because this is what I am familiar with and am qualified to speak of as a university Professor and "higher education native", so to say. The argument I propose, however, is intended to be relevant for a broader context and, as such, I will speak in general terms whenever I can. When I speak of higher education degree programmes in music performance, I think particularly of those studies where the one-to-one relationship between the student and the musical instrument performance teacher makes up most of the study programmes implementation and where other types of teaching are considered supplementary to the main instrument activities (Angelo et al., 2019, p. 87). From this perspective, the primary responsibility (or a burden depending on whom you ask) to educate future sustainable citizens - in addition to being brilliant, sought after musicians 
- rests with the main instrument teacher. Where most of these teachers are hired professionals from symphony orchestras and from the freelance market, which is the case at my home institution, we see that the new state policies, to them, may seem alienating and unrealistic. "Am I not just supposed to teach them how to play an instrument?" the craftsteacher might rightfully ask from the perspective of the conservatoire tradition from which most of us teachers come. This phenomenon can be considered a direct effect from the accelerating (particularly from 2015, onwards) academisation and centralisation of music performance studies where earlier conservatories became subjected to the same university standards as physics, mathematics, health care, engineering, etc. (Angelo, et al. 2019; Rolfhamre, 2020).

"Can we buy virtue?" is a provocative, eye-catching title. It is easy to respond: "of course not", or (from a successful, mischievous business manager's perspective) "why not?" by reflex and discard it as a nothing more than a rhetorical provocation. I argue, however, there is more to it than that, and that it is not only valid as a rhetorical effect, but is indeed a relevant question to ask in today's educational climate. This chapter is an armchair analytical philosophical continuation of a paper published elsewhere (Rolfhamre, 2020) where I argue that educational quality in higher education is very much a rhetorical matter. In a context based on frictions between managerial quality assurance and classical musical instrument performance education, I pinpoint a consumer-product relationship that affects all parts of the study programme: from recruiting new students to nurturing their competence (professional and otherwise), to judging their development in the end where the teacher is somehow always at stake. The student-teacher relationship is central to how we judge quality in Norwegian state higher education study programmes, and what is offered is not alone a matter of artistry and performer integrity, but of funding mechanics where there is an intricate complexity where funding, generalisability and the particular is in constant inter-dependence. In sum: classical musical performance degrees are, in a sense, commodities and the performance teacher is a service the university offers its students to get their "money's worth". As I argue there, we should dedicate "... more focus on enabling managerial processes and quality work 
nurturing role-models for lifelong learning and dynamic employability than for merely satisfying current market demands from quantitative reasoning" (p. 114).

Taking the lead from Julia Annas' (2011) virtue-as-skill, further placed within a phronesis-ecology drawing on Hansen (2007), I will, here, continue one particular aspect of this perspective to elaborate on what implications the Norwegian state higher education funding system may have on the higher education music performance teacher's perceived mandate. From the perspectives of music pedagogy, rhetoric and virtue ethics, I will offer an intervention within a complex discourse with no beginning and no end, to propose that ethical perspectives (here, virtue ethics in particular) deserve more attention, not only in the philosophical realms but also in didactics, on-the-floor pedagogy and in nurturing future generations of main instrument teachers. In doing so, I hope to offer a small contribution to the ongoing debate of who the teacher and student should be and what they should learn and why. In particular, how classical tradition-bound competencies should both relate to, and make themselves able to develop on their terms within, a neoliberalist, policy-driven society.

A fundamental perspective to this argument is how Julia Annas articulates virtue in her Intelligent Virtue (2011). On her account, virtue is something that we can work on to develop and improve as long as we are doing so intentionally while aspiring to a particular ideal. As Seneca reminds us, for us to be motivated to cultivate virtue, there must be some possibility of it ever becoming a reality. Virtue, then, must be something that we can conceptualise and utilise as a personal, achievable goal (a state of being, acting, etc.; Seneca, 1917, p. 22). From an Aristotelian perspective, we can divide the virtues into those about the intellect (theoretical and practical) and character (temperance, courage, compassion, etc.). Traditionally, the music performance departments have perhaps been readily associated with the first, the intellectual side of virtue, by design (e.g. bachelor's and master's theses, aural analysis, music theory, performance technique, etc.). In the light of the more recent trends to impose on higher education to cultivate transcending values (the UN sustainability goals above), however, we see a new need also to address more carefully how we relate to the second category: the virtuous character. 
This is where phronesis comes into play as it takes its starting point in practical and theoretical knowledge and systemises a way to actively seek to transcend (Socratic Eros), aiming for the unattainable, divine wisdom (Sophia). One apparent conundrum here, is to what conception of virtue we should aspire? Should it be those portrayed by the UN or the national state? Should it be that of the student or the teacher? Or should it be something completely different? In this present context, however, I am not so much interested in the what, but what it means for us to pursue the how. That is the implications on our mandate from the definition of it to be something we should convey to our students in some way.

First, I pursue three different usages of the verb "to buy" to exemplify why I find the chapter's title to be relevant and valid. This sets the premises for the following turn to rhetoric to highlight the starting point's persuasive functions and incentives. Subsequently, I briefly relate the argument to Butlerian performativity to emphasise its relation to normativity, inclusion-exclusion and the theoretical possibility of "breaking free". From this position, I draw on Aristotelian phronesis, mainly through the positions held by Hansen (2007) and Kristjánsson (2014) to sketch up an ecology in which the final segment of the present argument can unfold: how does this all affect the teacher's (actual or perceived) mandate?

\section{Buying $_{\mathrm{xyz}}$ Virtue}

When looking up the verb "buy" in the Cambridge Dictionary (2020), we find three main entries: (1) "to get something by paying money for it" (buyx below); (2) "to pay someone so that they do what you want or do not cause you any trouble" (buyy); and (3) "to believe that something is true" (buyz). Here, I will make a short note on each of the three possibilities to build a cumulative understanding of the word as an unlocking mechanism for the argument to follow (buyxyz).

\section{Buy : Paying for it}

In private tuition, the consumer-product relationship is easy to identify. We pay for classes to become better musicians. It may not be a cheap 
matter, so we scout different teachers and judge their competence, profile, price and availability before we make our decision. Although higher education in Norway is "free of charge" (Act Relating to Universities and University Colleges, 2005, \$7-1), it is not to be overlooked that it is a substantial personal investment. We may have to move to somewhere closer to campus and pay for rent, Internet, TV, food, transportation, insurances, literature, musical scores, instruments, student organisation registration fees, etc. Further, we invest time that we could have used to do something else, elsewhere.

\section{Buy $_{\mathrm{y}}$ : Paying for it (reversed)}

To pay someone so that they do what you want or do not cause you any trouble is a classical narrative leading to corruption. Often associated with a sort of cynical, intimidating power-relation - "if you do this for me, I will provide you with opportunities to become professional, but if you do not ..." - we soon think of the twenty-first-century \#metoo phenomenon, the impeachment of Trump in late 2019/early 2020, spy or mafia-films, etc. However, it does not have to be big, loud and bold. It could be a simple thing as compassion and kindness returned overtime to build allegiance based on free loyalty. It could be a milder, more fuzzy version of buyz below where I convince my students through praise, inclusion and acceptance that my way is the way to go. I award them with inclusion so that they believe in my cause and speak well of me over others, to become my fans, in a way. This goes beyond them accepting my knowledge offer on their terms to become a situation where I directly invest in them to make them do what I want in a manipulative manner (mostly in a negative way, but not always).

\section{Buy ${ }_{z}$ : Believing it}

When I believe an argument presented to me, I can buyz it. It is part of a rhetorical transaction where someone's intended act of persuasion succeeds and leads to a state of conviction, an acceptance of the truth or, at least, seems logically sound. The epistemological opportunities that this 
offers can, of course, be exploded far beyond what fits the scope of the present paper, but let it suffice, for the present being, to say that conceptions of truth, knowledge and to know are three very different things. Now, more than perhaps ever, are we questioning what truth is and what consequences it has on society as a whole. Lee McIntyre (2018) informs us that parts of the new developments are related to a shift from individual conviction to a collective rejection of so-called objective facts, leading to alternate realities which - in a global political climate - leads us to devastating collisions. Using alternative facts to assert "political dominance" is not only a matter of science, but of rhetorically constructing the world, resulting in, what I like to call, puto ergo recta (I believe; therefore I am right) and, or sentio ergo recta (I feel; therefore I am right). What matters is whether we are at the right time and place to set it about. So, in what sense are we buyingz virtue?

\section{A Note on Rhetoric}

Rhetoric, here then, is not the only key to quality assurance (Rolfhamre, 2020), but also the acceptance of truth and worldviews in general (at least in this simplified argument). Perelman and Olbrechts-Tyteca (1969) differ between conviction (the absolute, an end) and rhetoric (an action, a process). Rhetoric, accurately, represents an activity to stimulate a willingness to act. The educator, supported by their position, holds a particular position where those enrolled to the study programme are already "willing to act" and willing to be convinced if they can buyz the arguments presented to them. The rhetoric of the teacher can, then, be influential in promoting whatever. From this perspective, we can, for instance, speak of (1) a rhetoric of virtue's importance (who says virtue is essential and why? That is, the power of definition); (2) a rhetoric as virtue itself (being a competent rhetor); (3) rhetoric as an agent in promoting other virtues (to persuade why we should all become moral, compassionate beings), and rhetoric's basic operationality (logos, ethos, pathos) in forming the virtue being conceived. With the latter, are we, for instance, in a political debate, good at presenting solid facts (assuming that we understand them sufficiently), or blaming the others (for 
something or anything)? Do our arguments contain actual content, or are we submitting ourselves to rhetorical pyrotechnics? Are we convincing just because of who we are? Moreover, with whose content are we trying to persuade others? (There are, of course, other possibilities omitted here for the sake of space.)

The teacher's voice and strategy in making their students virtuous are pivotal for future education and suggest that we should seek the particular within the generic, rather than vice versa. In addition to the state and, or global blueprint of the virtues to be sought by global citizens, we should also ask how the educators' conception of the virtues to be conveyed and implemented holds its fort. Obviously, we are here in a close relationship between the particular and generic, the one and the other, obedience and disobedience, etc., where, taking the lead from Judith Butler, the one cannot exist without the other.

\section{Butlerian Performativity}

As Rivers and Weber point out, rhetorical texts are never isolated (although they are often studied as such). However, they exist in rhetorical ecologies where numerous rhetorical designs representing a multitude of formats, media, applications, audiences interact to make the situation possible, one inspires the other and also produces effects after its end (Rivers \& Weber, 2011). Often these texts cumulatively represent normative schemata, which manifest through culture and politics. According to Butlerian performativity, these norms and expectations are there not only to enslave us, but the very fact that we act according to them also enables them to exist in the first place. Furthermore, knowing that there are cultural "blueprints" out there, we further moderate our actions individually according to our expectations thereof with cumulative, collective results. As such, these schemata develop over time (Butler, 1988, 1990/2006). They are reinforced not only through action but also by a vast number of rhetorical formations and sensorial inputs, ranging from the poster at the bus-stop, the evening news broadcast, the coffee-break chat with the neighbour, community information flyers, etc. 
In recent times, more than ever, statistics and numbers have come to govern the norm of what is "normal". Wherever we turn we are bombarded with one in five; $40 \%$ of ...; balance; I ran faster today than yesterday; "Hi Robin, you haven't posted [on your social media account] in a while. Post now and reach over 500 readers"; "your baby is growing too fast, or is too long ...", and so on. In the bigger picture, when we come to health and justice, what is not within the boundaries of statistical normality is criminalised or made a disability with following rectification procedures to "help" the subject approach what is normal (Foucault, 1977/1991 1978/1998, 1965/1988; Perelman \& Olbrechts-Tyteca, 1969, loc. 1241). So in collectively doing our conceptions of $a$ virtue (both as actions, utterances, and through an ecology of rhetorical devices), we make that virtue both possible and existing.

However, what then if our collective, cumulative conception departs from the norm it seeks to respond to, that is, what the state policy demands is not precisely what it gets? Then we are establishing something else (obviously) which testifies to the "power of change" inherent in the Butlerian performativity. This is often where, I believe, policies meet difficulties. In realising them purely (crudely simply put), the mass must concur and exercise an understanding of the policy, which concurs with what it seeks to establish. However, when the mass does not necessarily concur - whereby laws, regulations and control mechanisms must be formalised and put in place to "help" those not complying to fit the norm and something else develops which may theoretically be equally good, but different: what then do we accomplish by forcing reports, performance indicators, quality assurance systems according to the blueprint, rather than the cumulative results as they appear? This is where I find it useful to resort to phronesis, for what virtue are we thus imposing on or nurturing in ourselves and our students? An instrumental achievement of elsewhere predefined "learning outcomes", so to say ("this is what it means to be virtuous", the state says)? Or are we enabling our community to critically relate to blueprints of all sorts to enact possible alternatives without being the "naughty child at the back of the classroom" (whom may not be difficult at all, but neurodivergent, have a complicated background story or merely is just disagreeing with the norm for any reason)? 


\section{Phronesis as Ecology}

The virtues promoted by the Norwegian state, for the higher education study programmes and the research activities accompanying them are generic nomenclatures at best with measurable, quantifiable results. Several of the UN's sustainability goals (2020), to which the Norwegian state subscribes, can be measured: We can, for instance, measure whether students get jobs after completing their study programmes, that is that they are employable but not necessarily virtuous. We can judge if the healthcare system "works" depending on how many people get back to work (not necessarily getting rid of their illness), how much longer people live, or how swiftly patients check in or check out of diagnostics, for instance. This quantifiable mechanics is easy and comfortable to resort to and trust in value creation- and economic growth-driven society, no doubt about that. However, if this is also the way we should educate virtuous musicians, we need to think about our options.

According to Hansen (2007), at the time of writing, educational research often comes short in this respect as they promote retrospective perspectives on what worked rather than what works, where, furthermore, the researcher already at the beginning of the activity have an idea of the goal to be presented at the end. As virtuous beings, we should move beyond instrumental realisations of poeisis (knowing that and how) and praxis (acting on poeisis) to become conscious of who we are, our values and norms and acts accordingly. However, from the state perspective, we are asked to fulfil the schemata instrumentally (mimetically) to become what we should. The Aristotelian ecology that Hansen (2007) offers consists, at the bottom of the wisdom-hierarchy, of poeisis and praxis. From this, we may deduce and construct from the particular the general through phronesis (practical wisdom). From here, we may embark on a quest for the unattainable universal, divine wisdom (Sophia) through the aspirational process of Socratic Eros where we can pursue the existential to supply the instrumental.

As such, Hansen separates between sorts of instrumental and transcending virtues. So the question is: what should main instrument performance education contribute? Here we see how "knowledge economy" is a tricky thing for the main musical instrument performance teacher. Should we, for instance, recruit many students and have them generate 
funding regardless of their finally achieved competence? (Note: in Norwegian state higher education, produced study credits reported to the state generate funds in return for the institution, which means that students have to pass their exam for the education to have sufficient finances to support its activities; [Rolfhamre, 2020].) Further, should we strive to have them excel at the level of praxis to become mainstream and widely employable to create workers (both would satisfy the UN's eighth sustainability goal in particular) or would phronesis be enough? Or should we aim at transcending instrumental knowledge and pursue Sophia? Moreover, how would we measure this in our students in any other means but rhetorical? An informing and revealing passage from the Norwegian Ministry of Research and Education about the a mbitions of national education makes almost all of the above concerns apparent:

Knowledge, and the ability to apply knowledge, is the most important competitiveness of Norwegian society. The collected knowledge capital is society's most important resource. It is vital for the working life, and it is essential to be able to handle the most important challenges to society, in short as well as long term. The educational system is the government's most important instrument to influence knowledge capital. The development of the working life will very much depend on the ability to utilise new technology created outside of our national borders. ... (Kunnskapsdepartementet, 2016; my translation)

Without doing justice to its rhetorical ecology, in a sense promoted by Rivers and Weber (2011), there are several reasons why these lines are troublesome (and more in line with the US critique offered by Nussbaum, 2010, than what one may initially think). Following such rhetoric, one would assume that knowledge creation serves value creation alone and that we can differ relevant research from the rest (and where does that place classical music performance, one may ask?) Research and knowledge production, as well as virtue, is, according to these standards, instrumental. It serves a defined goal. Wisdom, in the Aristotelian sense, then, falls short, and this is something of which the higher education teacher (whatever their field of study) must be aware. As Kristján Kristjánsson (2014) points out, virtue ethics in education must also seek to move beyond citing mere truisms to where it can promote actual cultivation of virtue. 


\section{The Teacher's Mandate and Generic Nomenclature}

Let us now conclude this exercise by turning to the centrepiece of this enterprise: the musical instrument performance teacher. Taking the lead from Elin Angelo (2017), the teacher's pedagogical activities has much to do with their perceived mandate. They may view themselves as pedagogues, craftspeople, musicians, administrators, mentors, "therapists", parents, "police officers", janitors, negotiators, philosophers, etc. Operating within frictions between personal, collective, institutional and political convictions in how they understand their profession and role, the teacher's identity (actual and perceived) sets the framework for their artistic ideal and pedagogical preferences. When further adding personal traits to the figurative equation - e.g. introversion/extroversion, sensorial preferences, technological literate/illiterate, and so on - we see not only that "professional understanding" and "teacher mandate" are exciting fields of study, but more importantly that they are a multifaceted concoction of individuals relating cumulatively to the general in their way (more or less removed from cultural norms). So why are we so often operating with the general within the public debate? That is, who are those "students", "teacher" and "researchers" we read about? In today's more or less overt click-bait rhetoric in the media (that is sensationalised hyperlink designs on the Internet to lead people to other pages, or elsewhere, preferably while also generating click-statistics for monetising adds), generalisations are overtly competing for our attention. It is not uncommon to find news articles, such as:

- "Studentene sliter med hjemmestudier" [Students are struggling with studying at home] (Svarstad, 2020) which argues that 9 out of 10 students feel less productive at home (which is not to say that they actually are)

- "Universities Should Ban PowerPoint. It Makes Students Stupid and Professors Boring". (Ralph, 2017) - particularly in contrast to "Research Reveals PowerPoint Is Not to Blame" (PolicyViz, 2019)

- "15 Things Students Really Want From Teachers" (Imafidon, 2020) 
In my view, these articles say very little about educational quality and effective learning. What they do, however, is to parade the author's personality, conviction and perceived mandate (which may further be influenced by geography, demography, age, personal history, etc.). We may also ask who these generic "students", "teachers" and "professors" are? Clearly, one way of learning, teaching and researching does not fit all. Nevertheless, it is essential, I hold, that we separate rhetorical scaffolds from the actual content, that is, that we make a shift of emphasis from how it is said to what is being said.

Furthermore, through ten interviews with music education professionals focused on mandate, research and knowledge, Angelo et al. (2019) identifies a sense of reported internalised knowledge leading to an "awakening" which would suggest an aspiration for Socratic Eros. On their account, music performance, as well as the arts in general, can provide such transcending opportunities through handicraft, entrepreneurship and critical reflection (which would comply with the Aristotelian crafts-wisdom-ecology). In the romanticist sense, following the post-1730s increased search for the sublime following the pronunciation of "aesthetics" (Rueger, 2011, p. 201), arts education can arguably be particularly good at this experiential, emotive state of being. However, it remains unclear how this can be formalised as a non-instrumental virtue of character that naturally - not only forcibly through chameleonrhetoric to defend one's existence within a policy-driven educational economy - creates focused society-building citizens who contribute actively to develop various ethical commitments for "the greater good" wherever that may lead us (an interesting account on the interrelation between emotions, politics and ethics can be found, e.g., in Nussbaum, 2001). To simplify (too much, I admit, but I aim for a rhetorical point), experiencing something beautiful which sparks the imagination and emotions is not the same as developing moral and compassion. It would seem that when policies and knowledge economy (to use state-nomenclature) ask the teacher to be instrumental for a defined end, transcending ethical perspectives becomes secondary goods operating outside of, or on parallel tracks within, "quality assured" educational frameworks. It will thus remain an unmonitored (whether that should at all 
be desirable?) individual, local enterprise. If we then set the two strands up against each other - (1) instrumental fulfilment of schemata, and (2) unmonitored, individual yet cumulative ethical maturing and growth what we gain is perhaps rather a growing body of critics (opposers, or disloyal policy-subjects) than actively contributing devotees. Indeed, in this post-truth society, it is not even a simple matter to agree that there is even $a$ problem (cf. the ongoing global warming debate in public media: is there a problem or not?). So, figuratively, if we cannot agree that there is a problem, then how can we agree to its solution? In fact, would not the "good life" and the "greater good" somehow suggest inclusion, equality and or equity, at least from today's Western rhetorical climate? However, to follow a Derridean line of thought, is not the stigmatisation of homophobes, racists, the ignorant, etc. also a non-inclusive operation and, thus, working against its logical paradigm: to let all be who they are? Even liberal, inclusive cultures represent a normative operation in the Butlerian sense where there exists a blueprint, upheld by its enactment. By being what it is, it excludes, or at least relate very strongly to, what it is not. As Amia Srinivasan argues in a different context, compassion is not just compassion. It relies on a specific perspective, agenda and positioning within a hierarchical relation between insider and outsider. Therefore, we must also ask who is being compassionate to whom, for what end and to what effect. Should the responsibility of inclusion, for instance, rest with the oppressor or the oppressed (Srinivasan, n.a., p. 9)? These perspectives also govern institutional cultures and what perspectives we foster, as role models, in our students. The teacher mandate thus reaches beyond what it means to be a music pedagogue. It also suggests that the teacher is a role-model citizen. Moreover, by opposing, for instance, the UN's sustainable development relevance to the music performing profession, one reformulates, before the student, such policies as the other and thus, does not comply with the incentives for universities to meet the goals of bringing up new, (UN-) sustainable citizens. On the other hand, if the goal-delivery manifests itself too much in the educational setting, one may risk losing the presence of the long-standing tradition that makes what we do what we do (presentism over historicism, that is). This is, to further distort the teacher's mandate, quite a responsibility 
when teaching clarinet scales, or vocal warm-ups, or classical guitar nail filing. Reductio in absurdum, aside, what these repeated parecbases leave us with, is a clear demand for future research on teacher's mandate beyond the classroom and in response to the outside world, not only as professionals but as local, cultural, national, international, global and local citizens and agents. If we are to expect, as the politicians would have us do, that higher education across all disciplines (and education in general) should securely generate agents of future sustainable societies, then we must revisit the nucleus of the rhetorical efficacy of knowledge creation and implementation: the teacher. The main instrument performance teacher - with their historically, tradition-bound, conservatoire heritage - makes a particularly interesting case because of their very different perspective from the general neoliberalist, new public management policies they are subject to, as part of a knowledge economy.

\section{Concluding Remarks and Suggestions for Future Research in Higher Education Music Performance Pedagogy}

So can we buy virtue through music performance degrees? In an instrumental fashion from phronesis down to poeisis and praxis, perhaps: yes; but from phronesis to Socratic Eros aiming for Sophia, perhaps: no. From a policy-fulfilling perspective of upholding norms and blueprints, perhaps better than if we unleash the cumulative developments of the unknown (which again may form new norms and blueprints through its iterability). To conclude this never-ending excursion into all and nothing, the canvas presented above raises a multitude of important questions to pursue in future research. When enrolling in a music performance degree at a state university, for instance: are we investing (time, money, effort, etc.) in actually becoming virtuous?; or in the possibility of becoming virtuous?; or to gain the conviction that we have the possibility of becoming virtuous? That is, in investing in a degree, to what extent can we expect and demand virtue? Further, from the student's perspective: is virtuous living a primary goal or is it just a secondary matter to be considered after learning to play their instruments better (however one defines "better")? 
Is it at all part of their scope when applying to the study? In sum: whose rhetoric makes virtue important for whom?

My position is that when operating as music performance educators according to such narrow economy driven policies (cf. Kunnskapsdepartementet, 2016, above), we must not only talk about lower-level wisdom but also find ways to educate and foster knowledge in an active transcending fashion, beyond truisms. Music's preference (at least to later history's perspectives) of the sublime, the aesthetics, the emotive, the subjective, and the experiential would suggest an attractive, natural point of departure. However, we must dedicate more thought to how to shift domains from experiencing something, to actively developing ethical perspectives. I confess I do not know how to do this effectively (I would be naïve, and perhaps arrogant to suggest that I do, at least dogmatically), but I argue that it needs to be given more attention in music pedagogy research in general. Returning to Kristjánsson, we should move towards additional aspects of actual cultivation of virtue beyond instrumentalism and truisms.

In the end, we should perhaps ask ourselves the following about virtue in/as/from/through musical instrument performance degree programmes: Are we buyingxyz it?

Acknowledgements: I wish to thank Elin Angelo for inviting me into this anthology project to share my thoughts on the subject.

\section{References}

Act relating to universities and university colleges. (2005, 1 April). Lovdata. https:// lovdata.no/dokument/NLE/lov/2005-04-01-15

Angelo, E. (2016). Music educator's expertise and mandate: Who decides, vased on what? Action, Criticism, and Theory for Music Education, 15(2), 178-203. http://act. maydaygroup.org/articles/Angelo15_2.pdf

Angelo, E., Varkøy, Ø. \& Georgii-Hemming, E. (2019). Notions of mandate, knowledge and research in Norwegian classical music performance studies. Journal for Research in Arts and Sports Education, 3(1), 78-10o. https://doi. org/10.23865/jased.v3.1284

Annas, J. (2011). Intelligent virtue. Oxford University Press. 
Butler, J. (1988). Performativity acts and gender constitution: An essay in phenomenology and feminist theory. Theatre Journal, 40(4), 519-531.

Butler, J. (1990/2006). Gender trouble (Routledge Classics). Routledge.

Cambridge Dictionary. (2020). Buy. https://dictionary.cambridge.org/dictionary/ english/buy

Foucault, M. (1965/1988). Madness and civilization: A history of insanity in the age of reason. Vintage Books Edition.

Foucault, M. (1977/1991). Discipline and punish: The birth of the prison. (A. Sheridan, Trans.). Penguin Books.

Foucault, M. (1978/1998). The history of sexuality: The will to knowledge. (R. Hurley, Trans., Vol. 1). Penguin Books.

Hansen, F. T. (2007). Phronesis and wuthenticity as keywords for philosophical praxis in teacher training. Paideusis, 16(3), 15-32. https://journals.sfu.ca/pie/index. $\mathrm{php} / \mathrm{pie} /$ article/view/132

Imafidon, C. (2020). 15 things students really want from their teachers. https:// www.lifehack.org/articles/communication/15-things-students-really-want-fromteachers.html

Kristjánsson, K. (2014). Phronesis and moral education: Treading beyond the truisms. Theory and Research in Education, 12(2), 151-171. https://doi. org/10.1177\%2F1477878514530244

Kunnskapsdepartementet. (2016). Fag - fordypning - forståelse - en fornyelse av kunnskapsløftet [Subject - immersion - comprehension - a renewal of the knowledge promotion reform]. Meld. St. 28 (2015-2016). Report to the Storting (White paper). https://www.regjeringen.no/no/dokumenter/meld.st.-28-20152016/id2483955/sec1

McIntyre, L. (2018). Post-truth. MIT Press.

Nussbaum, M. C. (2001). Upheavals of thought: The intelligence of emotions. Cambridge University Press.

Nussbaum, M. C. (2010). Not for profit: Why the democracy needs the humanities. Princeton University Press.

Perelman, C. \& Olbrechts-Tyteca, L. (1969). The new rhetoric: A treatise on argumentation. University of Notre Dame Press.

PolicyViz. (2019, 23 October). Research reveals PowerPoint is not to blame. PolicyViz. https://policyviz.com/2019/10/23/research-reveals-powerpoint-is-notto-blame/

Ralph, P. (2017, 25 August). Universities should ban PowerPoint. It makes students stupid and professors boring. Business Insider. https://www.businessinsider.com/ universities-should-ban-powerpoint-it-makes-students-stupid-and-professorsboring-2015-6? $r=\mathrm{US} \& \mathrm{IR}=\mathrm{T}$ 
Regjeringen. (2020a). 2030-agendaen med bærekraftsmålene [The 2030-agenda of the sustainability goals]. https://www.regjeringen.no/no/tema/utenrikssaker/ utviklingssamarbeid/bkm_agenda2030/id2510974/

Regjeringen. (2020b). Bærekraftsmålene [The sustainability goals]. https://www. regjeringen.no/no/sub/fns-barekraftsmal/id2590133/

Regjeringen. (2020c). Kunnskap og FNs bærekraftsmål [Knowledge and the UN’s sustainability goals]. https://www.regjeringen.no/no/tema/utdanning/innsikt/ internasjonalt-kunnskapssamarbeid/utdanning-og-nye-barekraftsmal/id2398973/

Rivers, N. A. \& Weber, R. P. (2011). Ecological, pedagogical, public rhetoric. College Composition and Communication, 3(2), 187-218. https://www.jstor.org/ stable/23131582

Rolfhamre, R. (2020). Through the eyes of an entangled teacher: When classical musical instrument performance tuition in higher education is subject to quality assurance. Action, Criticism, and Theory for Music Education, 19(1), 81-117. https:// doi.org/10.22176/act19.1.81

Rueger, A. (2011). Aesthetics. In D. M. Clarke \& C. Wilson (Eds.), The Oxford handbook of philosophy in early modern Europe (pp. 201-223). Oxford University Press.

Seneca. (1917). On leisure. (F. Miller, Trans.). Harvard University Press.

Srinivasan, A. (n.a.). The political limits of compassion. http://users.ox.ac. $\mathrm{uk} / \sim$ corp1468/Research_files/Nussbaum\%20-\%2opolitical\%2oemotions\%20 paper_Palgrave.pdf

Svarstad, J. (2020, 14 April). Studentene sliter med hjemmestudier [Students struggle with studying at home]. Forskerforum. https://www.forskerforum.no/studentenesliter-med-hjemmestudier/

United Nations. (2020). About the sustainable development goals. https://www. un.org/sustainabledevelopment/sustainable-development-goals/

Utdanningsdirektoratet. (2020). Core curriculum - values and principles for primary and secondary education. https://www.udir.no/lk2o/overordnet-del/?lang=eng 


\title{
Facing the Soprano: Uncovering a Feminist Performative "I" Through Autoethnography
}

\author{
Runa Hestad Jenssen \\ Nord University
}

\begin{abstract}
This article unpacks three auto-narratives drawn from my embodied experiences journeying from soprano to researcher. A feminist theoretical performative "I" is created through the use of performative autoethnography, a position of situated knowledge and Judith Butler's thinking of gender as performative. I explore the query: How is a singer's feminist performative I created through autoethnography? By unpacking my lived experiences I establish a connection between the I and the context I live in, referred to as "the Other". This connection then illuminates how my voice has been constructed and disciplined to that of a normative feminine soprano by attaining and repeating actions from the social-culture context of singing. I also leverage off Butler's thinking and how it may foreclose the attention to the materiality of the body, and lean into a performative embodied, new perspective. Embracing both the soprano and researcher role I create a position that brings me into a "liminal space". I do this to better understand the intersection of music education and gender, the becoming of a researcher, researching with the "inside out", and to embrace the material body's actual contribution in (to) the web of meanings in the sociocultural context of singing. By carving out a connection between being a soprano and moving into my researcher voice, I offer this article as an expanded way of knowing - a knowing through being. In turn, such insights offer epistemological and ontological ways of thinking for those experiencing similar encounters.
\end{abstract}

Keywords: embodiment, feminism, Judith Butler, performativity, performative autoethnography, voice

Citation of this chapter: Jenssen, R. H. (2021). Facing the Soprano: Uncovering a Feminist Performative "I" Through Autoethnography. In E. Angelo, Jn. Knigge, M. Sæther \& W. Waagen (Eds.), Higher Education as Context for Music Pedagogy Research (pp. 113-135). Cappelen Damm Akademisk. https://doi.org/10.23865/ noasp.119.ch5

License: CC BY-NC-ND 4.o. 


\section{Prelude}

I grew up with a feminist mother. She showed me pictures from the streets of Oslo in the 1970s where she went to demonstrations. She sowed feminist seeds in my upbringing - brown clothes, a bedroom painted green, and an admonition to go into every situation with my back raised. "The most important thing is not what you have, but what you are about to become, Runa”. But at that time, I truly loved pink! When my mum was studying and was mostly at university, my dad painted my room, at least the closet doors, light pink, and we ordered floral curtains at Sparkjøp. I educated myself into a profession that is considered feminine. I became a singer and spent six years training to learn how to produce beautiful sounds and move gracefully on the opera stage, in beautiful dresses, and often in the role of the naive and beautiful maid or princess. I loved it!

Now, I am married. I have four children. In a way I have supposedly fulfilled the criteria for society's normative conception of being a woman. As I was tuning the theoretical lens in my academic work which studies working with the adolescent female changing voice, my mother's seed began to germinate. Carving out a critical approach, I felt a need and desire to focus on women's thinking and imprints. My study is no longer "just" a vocal didactic project, but rather it has morphed into a multi-layered contribution: for women in academia and in the arts. Oh, and by the way, I have three female supervisors and a large picture of Simone de Beauvoir hanging outside my office door.

\section{Introduction}

This article shares methodological and theoretical wonderings that sit at the intersections of feminism, embodiment, performativity and autoethnography. Through feminist performative autoethnography as a method of investigation, I specifically lean on the work of Judith Butler (1990) to unpack how my becoming, from soprano to researcher, enables a feminist perspective. Through this journey of becoming I have found a new voice, my feminist performative "I" (Pollock, 2007; Spry, 2011). The notion of a performative I has been articulated by different scholars with slightly different interpretations and connections, 
however for the purpose of this article I specifically lean on Spry's use of performative I, which draws this into the context of autoethnography. Actually, it has been more of an uncovering, not too dissimilar to the peeling of an orange, removing the thick skin of the orange to get to the flesh. I often use this orange metaphor when describing my vocal-technical philosophy to my university students - explaining to them how external tensions in the body makes it difficult for a singer to find physical anchorage. Without connection to the core of the body the voice floats alone without the passion, sorrow, hate, or joy to be conveyed in the story of an aria. I believe the way to find the core is to search for emotions and evoke experiences - cry, whine, laugh! Find the primal voice in you. However, this requires courage. At first glance, some singers seem to have "thick skin". The thick-skinned stand out to be the toughest and dare to throw themselves into the unknown, while the "delicate" ones seem to hold back. Those with a more vulnerable skin, framed with tensions, must spend time finding the core of the singing body. Either way, the singer must find their own ways to "peel the orange", because when finding the core, the singer discovers, feels and understands their own voice, and the voice and personality merge. In order to find the core, it is necessary to expose one's vulnerability. Now it was my turn to be brave.

The question that this article explores is: How is a singer's feminist performative I created through autoethnography? This question has emerged from my own lived experiences. I share auto-narratives to establish a connection between the I, and the socio-political/cultural context I live in, referred to as "the Other". In this article I describe how I started to investigate the I through autoethnography. Doing this I realized that the performative I, was less a dialogue with the self, and more a dialogue with how the self is always and already in sociopolitical formation with and by others and culture. By bridging the performative I and the field of feminist theory, I anchor myself in Judith Butler's feminist theoretical perspective. This has enabled me to investigate my embodied experiences, shared through three auto-narratives, and offer points of departure around the notions of what it means to be a soprano and researcher. I embrace subjectivity with a labor of reflexivity (Madison, 2011), and 
analyze my encounters of becoming a soprano and a feminist researcher through Butler's thinking of gender as performative and from the position of situated knowledge. I also engage with Butler's thinking and how it might foreclose the attention to the materiality of the body. Leaning on a new material feminist perspective I analyse my lived experience to better understand the intersection of music education and gender, the becoming of a researcher, and how a performative embodied and feminist approach can critically investigate and dismantle oppressive norms in the sociocultural context of singing. Towards the end of this article, I embrace both the soprano and researcher role, positioning these roles in what would be viewed as a "liminal space" (Boyce-Tillman, 2009; Butler Brown, 2007), in turn offering an expanded way of knowing, a knowing through being (Bresler, 2019).

\section{The Skin of the Soprano}

I frame this article around the socio-cultural construction of "the skin of the soprano". The soprano-skin is a border that feels, and I envisage this boarder to be porous, responsive to my lived experiences and encounters. Laying bare my soprano skin is a way of feeling the field (Martin, 2019), a constant movement between the inside through my embodied experiences and from the outside from the perspective of a feminist researcher. Being an insider and an outsider of the soprano skin in the sociocultural context of singing, I create a space in-between where I dialogue with myself and the context of my lived experience. A space of transmission, where the boundaries become blurry and the voices intertwine with each other. I am not just an outsider or an insider, as a feminist autoethnographer I am both, searching for space between, a liminal space.

As a feminist, I see that I have been socialized into a gendered role in the field of singing. I have known resistance, but it is now with a methodology and theory to hold onto, that I am able to unpack this, redeemed by the autoethnographic and theorized by the feminist. Singing is an action where you are the "instrument" a performance where experiences become embodied. The nature of performance is an embodied practice (Pelias, 2018) and as a singer my soprano skin has been inscribed with practices 
and experiences. Like Martin (2019), I have found this to continue as I have become a researcher. Bringing experiences forth through embodied memories (Pink, 2015) is my way of using the term embodiment when investigating my auto-narratives. I see that my embodied experiences are not isolated to the context of singing, as Martin writes, such experiences "travel with us" (2019, p. 10). Facing my soprano, unpacking my soprano voice, in the narrative below I investigate what has travelled with me through embodied crossroads, exposing my vulnerable self.

\section{A Silver Soprano Voice}

I was one of those children who sang before talking. Memories are carried in my body of moments where my grandmother and I sang together. I would sit on her lap, experiencing 'musical skin contact". Grandma had a very dark voice, and was proud of it, but as I grew older, I noticed how excited she was for my bright, light, bell-like and pure high notes. I got to be the princess in the fairytale in theater performances. Apparently, this role suited me - I had long blonde hair and a silver soprano voice.

My father was an opera singer, I loved listening to him, practicing the role of Sarastro in Mozart's The Magic Flute. But best of all, I admired the high notes of The Queen of the Night. For hours I could listen to the soaring ice-clear tones.

When I was in my teens, the slight height in my voice vanished. I developed 'altitude fright'. The height, which had been my trademark, disappeared. I would love to go up there again, but there just wasn't a sound. My vocal teacher in high school asked me to sing with the alto group. I felt that this was degrading because I could not sing the first soprano anymore. I was crushed. I cried to my dad when I got home. He was, as always, clever, saying: "You don't need that much power on the notes, Runa. Let them flow freely with more air and with more body. Say a thousand thanks for what's coming out of your singing body". My father never had vocal lessons with me, but I remember those words so well.

Anyway, I became a singer. A soprano. I did not become the Queen of the Night, but Pamina and Michaela. Girls with their feet planted on the ground. Innocent, but fair and caring, and with loud belligerent tones, which resonated throughout 
the orchestra and in full applause. As a student, I was appointed to one of Europe's leading chamber choirs, as first soprano, as group leader. My voice was the ideal of the Nordic choral sound, the silver sound, which blended easily into the ideal homogeneous choral sound, which the choir was world renowned for. But I struggled. Quickly, my voice was tired and I often experienced huskiness, losing the power of my voice. Was it allergies, or knots on the vocal folds? It was as if my voice was living a life outside of me. It hovered here and there, often a little over-pitched, often with a "boy soprano sound". I had a whistle voice, with almost no vibrato. The vocal teachers asked for me to give more bodily support on my voice, a stronger connection to the core. However, the more I activated my support, the more tired I became. But beware, it sounded fine, it was the sound it was supposed to sound, the silver sound.

When I became a mother my voice changed, especially when I was pregnant with twins. My stomach was big, and I felt a low center of gravity and physical anchoring that I had been looking for throughout my career. Now I felt it! My voice got deeper and richer in timbre. I did not get tired singing the high notes, nor did I take it so seriously. I did not have the time to cry over a role I did not get. My voice changed, but so did life. Four children in four and a half years, and in addition a job at a university to feed them. Not quite what I had imagined. A voice and a life of change. But, now I sang well. My biggest voice change happened late in life, when I was not so occupied on fulfilling others wishes about what the sound of my voice or my appearance should be like. Then it loosened. The voice was part of me, and not a constructed sound, produced to meet the demands of vocal teachers, repertoire, choral conductors and coaches. I sang like myself.

Now I could sing for hours without "getting my larynx in my forehead". When I finally cracked the code, it did not matter anymore. I had other things to do, being a mother and teaching at university, a place where I could dig into literature and share my experiences with students. I could listen, uncover and influence. I could opt out of Western art musical ideals with which from I was raised and explore new sound ideals. And, I could do research. Researching the change of voice, the female voice change. I read articles on feminist autoethnography, feminist theory, and I wrote. My fingers floated over the keyboard. I barely read a paragraph before I had to write again. Yes, it sounds like a cliché, but this was my medium, my language, my movement to become a researcher. 
I have dwelled a lot on what I can share in such an auto-narrative and why I might share my experiences in such a way. I have always told stories. Through my singing, on stage, to my students and my children, however, I have mostly told the story of others. In the following section of this article I elaborate on how writing my auto-narratives became the connection to the methodology of feminist performative autoethnography, and I question why I wrote these auto-narratives, and how much could I share without exposing myself too much? I was afraid I would appear as an un-reflected soprano, but actually, those words made me reflect. I had to take a chance to investigate my own prejudices and being vulnerable and open to criticism was a risk I was willing to take. It is the risk of being a researcher, but this risk also made me capable of making a "pointed truth" (Averett, 2009, p. 361), where the practice of telling one's own story can reveal oppressive power structures in society and offers the potential for change.

\section{Diving into Feminist Performative Autoethnography}

I noticed that my personal experience as a classical soprano could be seen as knowledge that I carried, that perhaps allowed me to have a particular awareness when encountering my research, a performance sensitive way of knowing (Conquergood, 1998). However, experience means little until it is interpreted, until we interpret the body as evidence (Spry, 2016). Autoethnography can enable such a critical examination, but Facing the soprano is not exclusively facing the self. I am building over the course of this article to extend beyond the self. I am using the performative I, as a foundation, and as a way of understanding how my embodied encounters resonates within the wider cultural context, in the methodology of a performative autoethnography (Spry, 2011), which is a self-otherculture narrative construction. Performative autoethnography concentrates on this "intra-activity" (Barad, 2003). To voice the embodied sociopolitical construction of a soprano, I rely on the works of D. Soyini Madison (2006, 2011, 2012), Rose Martin (2019), Ronald J. Pelias (2008, 2018), Craig Gingrich-Philbrook (2005), Della Pollock (2007), Tammy 
Spry (2011, 2016), Victor Turner (1986) and others who view ethnography as performative. I see, as Turner (1986) notes, performance as "the explanation and explication of life itself” (p. 21), where lived experience, through theories of embodiment such as critical performance pedagogy (Pineau, 2002), where a focus on various bodies are a medium for learning and critical reflection. I view that this can be a starting point for a more porous way of understanding the voice, and a strategy of gaining understanding and empathy for others. Understanding the embodiment of each individual voice also emphasizes the body's materiality and its significant contribution into the web of meanings in the sociocultural context of singing. An equal way of understanding a researcher's becoming, researching with the "inside out", opens up the possibility of a liberation of women's voices, both as performers and researchers.

Facing the soprano, I engage with an embodied performative autoethnography, to critically speak the skin write the skin abstract the skin, articulate the skin of the soprano. But still, it was all about the I. How could I go beyond the self? Being a soprano, I had spent hours rehearsing in front of the mirror, focusing on myself, my sound, my timbre, my vocal expression and behaviour. Reading Butler (2005) I found a way away from the mirror; "the 'I' that I am is nothing without this "you", and cannot even begin to refer to itself outside the relation to the other" (2005, p. 82). Maybe autoethnography was not about the self at all, perhaps it was about "the wilful embodiment of 'we"' (Spry, 2016, p. 15). Thinking with embodiment recognizes the body as experiential and a way of being in and engaging in the world and constitutes such a position one sees the world from. Space and materiality are also a dimension of the work and help to bring human bodies together with the surroundings - the physical, social and cultural. I engage my bodily experiences, positioning my body within a culture - with the performative I as a foundation, connecting myself with the Other. I seek to capture the nuances in my embodied experience, in my complex interaction in the sociocultural context of singing, in music education, in being in the world, working towards "the texture of a living moment" as Pineau (2002, p. 47) beautifully writes. To do this "we seek the language we trust, one that catches the experience" (Pelias, 2004, p. 122). 
Extending beyond the self requires a clear positionality from the researcher, a positionality that demands attention beyond the self. As Madison (2012) writes: "We are not simply subjects, but we are subjects in dialogue with others" (p. 10). Extending beyond the self therefore requires a labor of reflexivity (Madison, 2011), that will "lead us to the benefit of larger numbers than just ourselves" (p. 129). Articulating how Facing the soprano is created through autoethnography is not "merely an implication of the self or being self-conscious about how the self illuminates the social" rather "it is an implication of the knowledge systems, paradigms, and vocabularies we employ in our contemplations to interpret and speak through the self and the social" (Madison, 2011, p. 129). With Madison's (2011) labor of reflexivity, I seek to use the performative I, as a starting point to fully acknowledge the embodied experience. I seek an reflexivity beyond the mirror, as Homi Bhabha (2004) describes: "this moment of reflection is never simply the mirror of your making, your frame of thinking, but a stillness sometimes heard in choral music when several voices hold the same note for a moment - omnes at singulatum - as it soars beyond any semblance of sameness" (p. iv). This resonates within my singing body. It is the richness, of every single voice, which blends together. A polyphonic sound, but from a single instrument.

Positioning myself as a feminist performative I, the I is no longer a solo, or as Gingrich-Philbrook describes as a "single call" (2005, p. 306). It is a dialogical performative (Madison, 2006, p. 321), where the I with the other, working as a "rhizomatically spreading architecture of multiple possibilities" (Gingrich-Philbrook, 2005, p. 306), because there is no I before a "we", or an I without a "you" (Butler, 2005). With such ideas in mind, how is my voice, the performative I, informed by the other, and how does it inform my engagement and representation of others? Instead of asking how the performative I is created, I ask what are the effects of the intra-action between the I with the Other? Intertwining feminist theory with the investigation of my auto-narratives, I seek to reveal the structures in the context of my experience. This has implications for my becoming and positioning as a researcher, a feminist researcher. To situate this further, in the following section I dive into the specific elements of the feminist theory I seek to engage with. 


\section{Positioning my Voice Through Feminist Theory}

I write my performative I from an epistemological positioning where all knowledge production is understood as located or situated (Haraway, 1991). Critical feminist theory begins from an assumption that research questions are never neutral, with Haraway mentioning the problem of claiming objectivity as "the god trick" (1991, p. 191). From my feminist research position, I do not claim objectivity. My feminist research voice is always present, making my research voice explicit. Based on the situated knowledge I possess, being a performer, through my soprano voice, I saw that there was a connection between epistemology and a narrative position. This resulted in an autoethnographic text which is performative in itself.

\section{Gender as Performative}

In this article I view gender as performative, leaning on Judith Butler's (1990) description of it as a "repeated stylization of the body, a set of repeated acts within a highly rigid regulatory frame that congeal over time to produce the appearance of substance, of a natural sort of being" (p. 45). I use Butler's theory of performativity as a way of understanding my actions as a soprano and into the becoming as a feminist researcher. By this I mean what behaviors, patterns of action and norms I have learned through repetition, and how they affect me. Through Butler's thinking about gender as performative, in order to appear as intelligible as soprano, I have imitated what I perceived as a "feminine practice". Butler claims these imitative practices, both linguistic and physical, help shape gender identities, and this is how they are understood as performative - gender is not something you are, but rather something you do. Butler speaks of gender as something that is created in a culture and society, however, she does not speak of the body as something predisposed. Butler writes from the perspective that there is no I without first a we (Butler \& Berbec, 2017). The body is shaped from the practices it is part of, and it appears to be stylized through speech and body actions, and that it is shaped in response to the other, the we. Articulating the theory of gender, or the body, as one that acts and performs according to 
the conversations of gender, conversations that are influenced before one even is born (Butler \& Berbec, 2017).

My soprano skin is an effect of the discursive practice situated in the socio-cultural context of singing. I question if it is my inner "female core" that becomes visible as a soprano? I was always told that I was "feminine" performing my soprano. According to Butler, this performance acts to fulfil the expectation of a two-gendered model, to maintain the image of the body explaining our gender. According to Butler, bodies should be understood as political constructs and this is related to who has and does not have power and has consequences for our way of acting. This is how I see gender playing a crucial role in singing, because it both restricts and opens up for creating a soprano voice. The soprano can be regarded as a fixed gendered phenomenon, an object unable to make resistance. But I ask: How might a more porous way to understand the socio-cultural context of singing enable further space, diversity, freedom and voice for those engaged in these practices? In the following auto-narrative, I voice this from an embodied experience on stage.

\section{Without the Operatic Voice}

I have been lucky to perform the character of Michaela in Bizet's opera Carmen. I recognized so much of myself in this character. A country girl, down to earth, caring and good at fulfilling the wishes of others. I loved my costume, the fabric, lace, was almost like a national romantic image. Curly hair, red mouth, but innocent. I experienced the visual and theatrical part of the role well. Having received the part, I started to worry about not fulfilling the aesthetic ideal of operatic singing, not reaching the high notes. I felt I lacked the expected sound. Sure enough, after the performance I overheard someone in the audience (this someone being an authority in the field): "Oh, Michaela was beautiful on stage, but she was the one without the operatic voice". My heart sank like a stone to my stomach. I had not met the expectations of how to sound in this role. I had failed.

I never told the story of "Michaela" to anyone, until now. I felt ashamed of it. I still do. It punched my stomach, my diaphragm - the singer's most crucial place for finding the core, a vulnerable place. Viewing my Michaela narrative as an embodiment of possibility and of error (Pollock, 
2007), my failure with not producing the expected sound, was an error, but an error of possibility, an error that does not solely exist for me, but for others. My embodied experience, the error, could be used to dismantle and deconstruct normative behaviours from the socio-cultural context of singing. Who was the Other sitting in the audience, punching my stomach? Why did I listen to this one person, who was an authority in the field, and not the other 799 people in the audience?

From the auto-narratives I have shared thus far in this article I see that I perform with a voice that is significant for me. I perform within a discourse which binds members of the socio-cultural context of singing in Western society. I view my performance in the socio-cultural context of singing as repeating acts of the soprano skin. As Butler states, these repeated acts are performed within highly ridged regulatory frames. My voice performs within the frame of the socio-cultural context of singing. My grandmother still worships my light bell-like soprano. I still love to get applause for my Pamina and I love wearing a princess costume, but, I am also aware of the acts that do not fit into the repeated stylizing of the culture. With an embodied performative approach I see that the acts that marginalize a part of my voice because they dissonate with the expectations from this discourse. As such, the socio-cultural context of singing can be understood to encourage disciplining acts. I see that the expression dissonance is important for me to consider. In music, dissonances are viewed as moments of disruption, a tension of sounds, which require further development or a dissolving resolution. In the previous narrative, Without the operatic voice, I experienced a dissonance, a strong tension, a sound that did not fit, which may never have resolved.

With this theoretical terrain as a backdrop, I recall the repeated stylization of the skin of my soprano. As a researcher, I can now see my development from another perspective, an embodied performative, new-material feminist perspective. Dwelling on my auto-narratives, I see they are closely linked to feminine performance, especially in relation to sound and gesture. I can now shed light on aspects from the frames around me, that confirms something, and marginalizes something else. Butler's notion on gender as performative, provides a ground to investigate the discourses about the soprano, and how the soprano is a result or a product 
of the discourses in the sociocultural context of singing, by performing the discourse. But, as Alaimo and Hekman (2008) state: "this discursive realm is nearly always constituted so as to foreclose attention to lived, material bodies and evolving corporeal practices" (p. 3). The materiality of the body is in fact what makes the body produce sound. Butler talks about the "act" of the body but does not elaborate on sound. Without the materiality of the body, the flesh, the primal sound of the human being, sound cannot be produced, and the singer is left with no instrument, only the discourse. Schlichter (2011) states that Butler's notion of gender performativity ignores the performative aspects of the voice, asking what it means to think of a body without a voice. The "core" of the voice. Peeling the orange is finding a more porous way to talk about the female singer body and the materiality it inhabits. This is actually what is exclusive with the voice - it is not a pair of strings you can change, it is "the I". Not the I as a representation, but rather the human living body as material, in intra-action with the discourse. It is "material-discursive" (Haraway, 2008, p. 4), which refuses to separate the two.

Making me intelligible as a soprano, I see that there are three repeated acts that arise from investigating my narratives through Butler's thinking of performativity. These acts are connected to norms and values existing in the socio-cultural context of singing. In the following sections I describe these three acts as: expectations in performing a normative feminine soprano, disciplining, and constructing my soprano.

\section{The Normative Feminine Soprano}

It is in appearance that gender can be performed, and the appearance of voice is part of this. Coming back to my narratives, I see I behave to fulfil norms that expect a soprano body to express itself with a "quiet body". I see historical norms formed by the patriarchy, in how to perform the role, how to take a submissive position, how to experience failure when not producing the correct and expecting sound. What freedom does the soprano then have to perform her own voice? By maintaining these norms not all bodies are given the right to sing. Some will be excluded, because they do not fit into the fixed pattern. And, why did I not think of 
these as oppressive norms when performing the role? Being in the role, I experienced the norms as natural habits. My body was deeply culturally constructed. Pineau (2002) advocates for refleshment, that appeals the body's innate ability to learn alternative behaviours. Because, habits can be broken.

With a Critical Performance Pedagogy Pineau (2002) advocates for a pedagogy that "embraces performance as a critical methodology that can be fully integrated throughout the learning process" (p. 50). This requires consideration of the body as a medium for learning. From where I stand, I view that teachers and students in music education are well suited for such an investigation, given that they have experience and practice of being "performance sensitive" beings. With Pineau's (2002) perspective in mind, there is the need to consider how those of us in music education might work to free ourselves from rigid frameworks that I see are embedded within music education (Nerland, 2003), and within this from oppressive norms, from dichotomous thinking that separates subject/ object, body/mind, nature/culture, female/male, into an "willful embodiment of 'we"' (Spry, 2016, p. 99). As Pienau (2002) notes, we must strive into a pedagogy that acknowledges that inequities in power and privilege have physical impact on our bodies, that put bodies into action, to help bodies become active, to help them break habits and structures. In this way music educators and researchers can "explore how socio-political relations are simultaneously reflected in and constituted through educational practice at the macro level of public policy as well as the micro level of classroom interaction" (Pineau (2002, p. 41).

Within my soprano self my voice is an instrument that is shaped to adhere to gendered norms. In my auto-narratives my voice is constructed into a porous silhouette of a soprano. In my experiences there have been guidelines for what this silhouette should be like. Through my autonarratives I see that I have been fulfilling demands for a normative feminine soprano. First and foremost, I see that this is related to two aspects; appearance and sound. The skin of the soprano that I meet the criteria for, is linked to a "girly" look - an innocent and docile behavior is pervasive in the narrative of the female singer articulated within the literature. According to Green (1997) and Rosenberg (2012), singers risk being 
"double exposed" to an inquisitive, normative gaze. Borgström Källén and Sandström (2019) points out that it is clear that the voice as an instrument is constructed on the basis of special terms and conditions and can be linked to the singer primarily using her own body in her musical performance. I have experienced this expected sound and behaviour of the soprano as a normative feminine sound. These particular feminine aspects of the voice require discipline of the voice (Björck, 2011; Borgström Källen, 2012, 2014; Hentschel, 2017; Strøm, 2018), and I have disciplined myself through imitating how a soprano "should" be and sound. I have performed my soprano voice within a fixed two-gendered category. Within this category I have fulfilled and repeated the patterns that exist in the socio-cultural context of singing. Only when I step out of the rigid frames of the socio-cultural context of singing do I see what kind of repeated acts that dissonate, and why. When I step out of the frame of the culture, my voice is released. I find my own way, from within my core, because I do not repeat expected actions, but rather, I find new actions. I am aware that my inner core is also sociocultural constructed. My voice is externally and internally co-constructed. Through the process of working on this article I have actively tried to dismantle and deconstruct the normative behaviour that exists in the sociocultural context of singing.

The skin of the soprano is such a gendered phenomenon, that the subject is performed into a socio-cultural context, without being aware of it. This resonates with Butler's theory that norms cannot be embodied without an action and they cannot continue without an action (Reddy \& Butler, 2004). In this way I can act and refuse the norms through action, an action of release. In my second narrative, A silver soprano voice, I describe how my vocal teachers asked for more bodily support because my voice sounded like a "boy soprano". Of course, I did, and this resulted in a silver voice. It was a voice that gave me a lot of vocal challenges, but it sounded the way it was expected to. When my focus changed, because life changed, and I stepped out of the ridged frame of the culture, the pieces of my voice "fell together". Now I was not trying to repeat acts from the social culture of singing. I performed my own voice, finding my core, but now within a different context. I focused on singing repertoire such as folk music, that did not focus so much on timbre, but the text. 
Butler claims that; "our responses to social environments over time are part of what produces the so-called 'facts' of the biological body" (Reddy \& Butler, 2004, p. 118). I was trying to not repeat actions of the culture, but now knowing and reading my experiences through Butler's work, I cannot separate the body, the I from the Other - the sociocultural context of singing and its discourse. Reading my experiences through the lens of Butler's work, I cannot separate my body from the cultural discourse.

\section{Disciplining the Soprano Skin}

In the auto-narratives I share I see a clear disciplining of my body. I moved with femininity on stage in the roles of the naive princess or maid. These feminine traits were often confirmed as correct by conductors, directors, vocal teachers and colleagues. The repertoire I was assigned was adapted to this expected expression as a female singer. In my auto-narratives I see that I can confirm the discipline of the body through my actions. The performative, to make a soprano voice, is rooted in the actions of the body, inclusive of the body's audio. Meeting norms for a feminine soprano also involves disciplining the vocalizing body. I experienced this as dissonance between my bodily actions and the vocal expression. My voice, in some discursive practices, was considered as a dissonance, as it did not meet the requirement set by the expectations of Western music's requirements. Trying to fulfill this criterion I got tired in my voice, I could not find my core, my support, because I did not connect to my body. Schlichter (2011) argues that Butler's notion of gender trouble remains fully contained by the logic of the visual, because Butler focuses on the picture of gender and in this way excludes the voice as "one of the relevant aspects of 'significant corporeality"' (p. 33). Schlichter continues to argue that this use of gender performativity as a theory "make bodies speak but simultaneously mutes their voices" (p. 33).

Voice is an extension of the soprano skin, from the inside to the outside. My point is that the skin, as a border between the inside and outside is porous. Voice as material, and the body as material, has its own agency. A more porous way of exploring the soprano voice, would be acknowledging the body, the instrument itself with agency. An intertwinement 
of the I and the Other. Because the suppression comes from the outside, from the socio-cultural context view of the voice as fixed gendered categories, and thereby constructed into a normative feminine voice. Drawing back to my auto-narrative, Without the operatic voice, I see there is a "mismatch" between the appearance and the sound; the picture of Michaela was perfect but the soprano skin did not sound the way it was expected to. The voice did not support the message in the act of the communication. It interrupted it. It dissonated. Butler's theory enables me to notice this, as well as to create resistance and further work to develop new flexible concepts. The voice demands it, because of its complexity.

From these embodied memories, as mentioned earlier, I analyze that I perform with a voice that is significant for me, but I perform it within a discourse, which is binding for those within the socio-cultural context of singing in western societies. As a result, I dissonance with the expectations from this discourse. In the literature Schei (2007) describes from a Foucauldian perspective how social structures and cultural patterns shape singers during music education and professional practices. While Nerland (2003) investigates how one-on-one music lessons constitute a cultural practice in relation to the work of Foucault and Bourdieu. When I experienced dissonances - when my soprano sound was not operatic enough, or that my biggest voice changed happened later in life when I became a mother, getting into a teaching position at the university - I was no longer occupied with fulfilling the norms of how my voice should sound and within the dissonance I could break out of the patterns I was accustomed to. Suzanne Cusick (1999), inspired by Butler's notion of performativity, analyzes speech and song in western culture as forms of discipline of the vocalizing bodies. In relation to Cusick's work, I see that my soprano body has been subordinated by the vocal and choral field, disciplining me to fulfill the image of the normative feminine soprano. My embodied experiences have created a dissonance, between the expectation and the sound I produced.

My construction as a soprano is based on traditions, where the focus on bodily discipline is taken for granted (Borgström Källén \& Sandström, 2019, p. 87). My becoming as a feminist is rooted in these invisible "taken for granted" moments. My feminist position also creates a theoretical 
frame for further research exploring possible "hidden" socializations in cultures that contain vocal practices where the female gender is overrepresented in its participation. Drawing from Turner's (1982) thinking, liminal space is both a cultural and personal place where transformation can be made. I have experienced that positioning me as a feminist researcher through autoethnography, has empowered me both as soprano and researcher, because I am able to break out of patterns and thus create a change. A liminal space is therefore a transformative position to hold.

\section{The Construction of my Voice}

My soprano voice is constructed by expectation to the skin of the soprano - expectations that come from a thinking of the voice as a gendered fixed category. Applying Butler's (1990 idea of gender as performative, the soprano has limited possibilities for action and performance outside of "meanings already socially established" (p. 191), and thereby the soprano has no full freedom "to voice". As a feminist thinker, I see that I am disciplined to fulfill femininity requirements; a constructed normative feminine soprano. The social construction of the soprano also focuses on constructions of gender. There is a preconceived way of viewing and disciplining a soprano, which therefore constructs the soprano's gender. The imperceptible construction of me as a soprano led to little resistance of such stereotyping. Through Butler's thinking of gender as performative, A silver soprano voice appears willingly to accept the position she is given. Subordination is thus the precondition for resistance and opposition (Davies et al., 2001).

As a soprano I accepted the position of subordination, fulfilling the demands from vocal teachers, directors, and orchestras. This acceptance of the conditions of possibility, does not come from me, but from the power of the practices I have lived in. This tells me something about the power of the practices I have embodied. But, I now face this subordination as a feminist researcher, and I have the possibility of seeing otherwise, as soprano and researcher. The position of seeing otherwise leads me to a liminal space, a place of wondering in the dark (Bresler, 2019). Carrying my soprano skin with me, I embrace my experiences as 
a situated knowledge into my becoming as a researcher. Moving into the end of this article I show how my positioning as a researcher, moving in between knowing and unknowing take me into a liminal space, being both a soprano and researcher, into a space of wondering and wandering.

\section{Moving Into a Liminal Space}

I carry my soprano history with me as I become a feminist researcher. I argue that, performing a gender, being a soprano or researcher are not fixed categories, and these roles are also performed. I am the one who brings Butler's ideas on gender as performative into my context, not as soprano or researcher, but as both at the same time. Moving between the fluid and porous border of the skin of the soprano and the feminist researcher, I find my space in between - a liminal space. Music has the possibility of creating a liminal space because it can take us into another dimension (Boyce-Tillman, 2009). Facing my soprano, using autoethnography as a method, I make myself vulnerable, and I throw myself into the unknown. However, as I throw myself into the unknown the boundaries between the soprano and researcher start to dissolve.

In writing this article I have been able to see what an exciting and vulnerable place this is to hold. By carving out my journey from soprano to feminist researcher, I offer a methodological path, a way of investigating, but also an example of positioning research from within a performative practice for those who experience a requirement for research-based teaching and practice in higher music education - for who is perhaps better qualified to see and know in new ways than performers? In this article my emphasis has been on how norms of being a normative feminine soprano has affected my becoming into a feminist researcher. Being a feminist researcher I can challenge the power such norms might hold - not only for the sake of my own change but also to incite change for others too. Not claiming objectivity or using "the God Trick" (Haraway, 1991), but merely writing with my honesty, and questioning my position as a product of the discourse I am investigating. From such a position of situated knowledge and through Butler's thinking of gender as performative, I now rearticulate my voice, from another perspective. 


\section{Coda}

This article emerged from my porous soprano skin and is a contribution to understanding the performativity of gender that exists in the practice of singing. I continue to ask: How is a singer's feminist performative I created through autoethnography? By revealing how my soprano has been constructed, and through the thinking of Butler's concept of gender as performative, I have stitched together my becoming a feminist researcher. Investigating my journey is the becoming as a researcher.

Returning to the orange metaphor I shared at the opening of this article, I see that an orange has no firm core. By pealing the skin of an orange, the pithiness is revealed showing us that there are many more complex facets to the orange, the orange is not simply a mass of flesh, but rather it is the intricate pith that holds it together. Peeling my orange, making myself vulnerable, has enabled me to feel the field and listen to the field with an expanded way of knowing (Bresler, 2019) into a transformative position in a liminal space. Perhaps my voice resonates with others, or it strikes out of the homogenous sound of the ensemble, as a solo, with a dissonance. What a dissonance is cannot be determined; it changes based on our context of living and situated knowledge. But, after a dissonance something new might happen - a change, a new timbre and texture.

In writing this article I have tried to better understand the intersection of music education and gender, the becoming of a researcher, researching with the "inside out" and to embrace the material body's actual contribution in (to) the web of meanings in the sociocultural context of singing. My performative actions are constructed according to the soprano as a gendered phenomenon, disciplined and constructed by the socio-cultural context of singing. I therefore have argued that female soprano voices are not given freedom to voice. Drawing on my first auto-narrative, and the words of my feminist mother: "the most important thing is not what you have, but what you are about to become". Thinking as a soprano feminist, I see that I am in a liminal space of becoming, throwing myself into the unknown, seeking a feminist performative I - a voice that might resonate with other voices, creating a complex melody of the self. 


\section{References}

Alaimo, S. \& Hekman, S. (2008). Material feminisms. Indiana University Press.

Averett, P. (2009). The search for Wonder Woman: An autoethnography of feminist identity. Affilia, 24(4), 360-368.

Barad, K. (2003). Posthumanist performativity: Toward an understanding of how matter comes to matter. Signs: Journal of Women in Culture and Society, 28(3), 801-831.

Bhabha, H. K. (2004). The location of culture. Routledge.

Björck, C. (2011). Claiming space. Discourses on gender, popular music and social change. [Doctoral dissertation, University of Gothenburg]. https://gupea.ub.gu. se/handle/2077/35723

Boyce-Tillman, J. (2009). The transformative qualities of a liminal space created by musicking. Philosophy of Music Education Review, 17(2), 184-202. https://www. jstor.org/stable/40495499

Borgström Källén, C. (2012). Utsikt från en minoritetsposition. [View from a minority position] In C. Olofsson (Ed.), Musik och Genus, röster om normer, hierarkier och förändring (pp. 26-39). Göteborgs universitet.

Borgström Källén, C. (2014). När musik gör skillnad - genus och genrepraktiker $i$ samspel. [When music makes a difference - gender and genre practice in interplay] [Doctoral dissertation, University of Gothenburg]. https://gupea.ub.gu.se/ handle $/ 2077 / 35723$ ?locale $=$ en

Borgström Källén, C., \& Sandström, B. (2019). Kropp, blick och plats - konstruktioner av dans- och vokalundervisning. [Body, gaze and place - constructions of dance and vocal education] Educare - Vetenskapliga Skrifter, (2), 73-92.

Bresler, L. (2019). Wondering in the dark: The generative power in the arts and in qualitative research. In N. Denzin \& M. Giardina (Eds.), Qualitative inquiry at a crossroads (pp. 80-95). Routledge.

Butler, J. (1990). Gender trouble. Routledge.

Butler, J. (2005). Giving an account of oneself. Fordham University Press.

Butler, J., \& Berbec, S. (2017). We are worldless without one another: An interview with Judith Butler. The Other Journal: An Intersection of Theology and Culture. https://theotherjournal.com/2017/06/26/worldless-without-one-anotherinterview-judith-butler/

Butler Brown, K. (2007). Social liminality of musicians: Case studies from Mughal India and beyond. Twentieth-Century Music, 3(1), 13-49.

Conquergood, D. (1998). Beyond the text: Toward a performative cultural politics. In S. Dailey (Ed.), The future of performance studies: Visions and revisions (pp. 25-36). NCA.

Cusick, S. G. (1999). On musical performances of gender and sex. In E. Barkin \& L. Hamessley (Eds.), Audible traces: Gender, identity, and music (pp. 25-49). Carciofoli. 
Davies, B., Dormer, S., Gannon, S., Laws, C., Rocco, S., Lenz Taguchi, H., \& McCann, H. (2001). Becoming schoolgirls: The ambivalent project of subjectification, gender and education. Gender and Education, 13(2), 167-182.

Gingrich-Philbrook, C. (2005). Autoethnography's family values: Easy access to compulsory experiences. Text and Performance Quarterly, 25 (4), 297-314.

Green, L. (1997). Music, gender and education. Cambridge University Press.

Haraway, D. (1991). Simians, cyborgs, and women. Routledge

Haraway, D. (2008). When species meet (Posthumanities). University of Minnesota Press.

Hentchel, L. (2017). Sångsituationer en fenomenologisk studie av sång i musikämnet under grundskolans senare år [Singing situations: a phenomenological study of singing in music classes in secondary school] [Doctoral dissertation, Umeå university] http://umu.diva-portal.org/smash/record. jsf language $=$ sv\&pid $=$ diva2\%3A1140734\&dswid $=6452$.

Madison, D. S. (2006). The dialogic performative in critical ethnography. Text and Performance Quarterly, 26(4), 320-324.

Madison, D. S. (2011). The labor of reflexivity. Cultural Studies Critical Methodologies, 11(2), 129-139.

Madison, D. S. (2012). Critical ethnography: Method, ethics, and performance (2nd ed.). SAGE.

Martin, R. K. (2019). Feeling the field: Reflections on embodiment within improvised dance ethnography. Journal of Dance \& Somatic Practices, 11(2), 197-207.

Nerland, M. (2003). Instrumentalundervisning som kulturell praksis. En diskursorientert studie av hovedinstrumentundervisning i høyere musikkutdanning. [Doctoral dissertation]. University of Oslo.

Pelias, R. J. (2008). H. L. Goodall's a need to know and the stories we tell ourselves. Qualitative Inquiry, 14(7), 1309-1313.

Pelias, R. J. (2018). Performative inquiry: Embodiment and its challenges. In R. J. Pelias (Ed.), Writing performance, identity, and everyday life (pp. 21-30). Routledge.

Pineau, E. (2002) Critical performance pedagogy: Fleshing out the politics of liberatory education. In N. Stucky \& C. Wimmer (Eds.), Teaching performance studies (pp. 41-54). Southern Illinois University Press.

Pollock, D. (2007). The performative I. Cultural Studies Critical Methodologies, 7(3), 239-255.

Pink, S. (2015). Doing sensory ethnography. Sage.

Reddy, V., \& Butler, J. (2004). Troubling genders, subverting identities: Interview with Judith Butler. Agenda, 18(62), 115-123. 
Rosenberg, T. (2012). Ilska, hopp och solidaritet. Med feministisk scenkonst in i framtiden. Atlas.

Schei, T. B. (2007). Vokal identitet. En diskursanalytisk analyse av profesjonelle sangeres identitetsdannelse. [Vocal identity. A discourse analytical analysis of professional singers' identity formation] [Doctoral dissertation, University of Bergen]. http://bora.uib.no/handle/1956/2549

Schlichter, A. (2011). Do voices matter? Vocality, materiality, gender performativity. Body \& Society, 17(1), 31-52.

Spry, T. (2011). Body, paper, stage: Writing and performing autoethnography. Routledge.

Spry, T. (2016). Autoethnography and the other: Unsettling power through utopian performatives. Taylor and Francis.

Strøm, R. (2018). Det usikre sangerlivet: En livshistoriestudie på langs og på tvers I klassiske sangeres sosiale praksis. [The uncertain singing life: A life story study alongside and across in classical singer's social practices] [Doctoral dissertation]. Nord University, Bodø. Norway.

Turner, V. W. (1982). From ritual to theatre: The human seriousness of play. Performing Arts Journal Publications.

Turner, V. (1986). The anthropology of performance. New York. 



\title{
CHAPTER 6
}

\section{Organ Teaching for Children in Norway: An Educational Field in Development}

\author{
David Scott Hamnes
}

Norwegian University of Science and Technology

\begin{abstract}
Teaching children how to play the pipe organ represents a radical revision of a well-established instrumental education field. This article provides an overview of organised teaching praxis in teaching children to play the organ, established in Norway in the early 2000s. Commentary on the limited previous research in organ teaching for children is provided, and based upon the findings in these studies and on praxis experience, areas which necessitate further research are identified. The practical teaching experience of the author provides a frame of reference throughout. Selected instrumental teaching studies related to teaching philosophies, motivation and organisational frameworks, as well as teaching materials (textbooks) are also included in the discussion. These aid in identifying areas in which potential and existing tensions in perceptions and methodologies call for study, evaluation and revision. The primary aim of this article is thus to identify and map the educational field's structural parameters (organ schools) and praxis in Norway, and identify areas where further research is required, in order to understand how childhood introduction to organ playing may inform organ education and the organist profession in general.
\end{abstract}

Keywords: organ education, children, motivation, collaborative learning, learning strategies, organ school, orgelklubb, Norway

Pipe organ pedagogy and its related research traditionally have been directed towards adolescents and young adults (Graabræk Nielsen, 1998; Hurford, 1990; Thistlethwaite \& Webber, 1998; Steyn, 2009). Formalised

Citation of this chapter: Hamnes, D. S. (2021). Organ Teaching for Children in Norway: An Educational Field in Development. In E. Angelo, J. Knigge, M. Sæther \& W. Waagen (Eds.), Higher Education as Context for Music Pedagogy Research (pp. 137-166). Cappelen Damm Akademisk. https://doi.org/10.23865/ noasp.119.ch6

License: CC BY-NC-ND 4.o. 
organ education for children aged 6-14 years requires a radical revision of both learning content and learning design. In that regard, this chapter contributes to explicating the development of organ education for children in Norway, and identifying and mapping formal framework factors and praxis in this field. This chapter presents an overview of instrumental organ education, in which existing tensions amongst structural factors, educational methodologies and requirements call for evaluation, and identifies areas that call for further research. It also identifies how aspects of organ teaching for children may be placed within a sociocultural context. Commentary on the limited body of relevant previous research in organ education for children is provided. An examination of this educational field may facilitate a better understanding of the processes related to instrument choice and the influence of teaching environments. Declining student recruitment to church music education programs appears to be latent in the field (Bjerke, 2020), although empirical data on student recruitment remains to be been studied. In relation to this, a deeper understanding of the role of childhood introduction to organ playing could inform both educational and employment outcomes as both higher education institutions and the church (as primary employer) hold vested interests in understanding paths to the organist profession.

This chapter has a descriptive design; it seeks to describe perceived reality and the characteristics of the phenomenon studied (Niiniluoto, 2001). It has four parts. In the first part, I present the main textbooks/ learning materials that are currently used in organ education for children in Norway. In the second part, I describe the phenomenon orgelklubber (localised communities or schools for organ teaching) as an organisational model in Norway. The third part is an elaboration of textbook studies within the field of instrumental music education as an evolving field of research. In the fourth part, I dwell on "early organ pedagogy" as a separate field of research and conclude with some prospective remarks concerning challenges and possibilities within this field. As an introduction to these four parts, I present the broader field of research to which this chapter contributes.

I have a vested interest in the dissemination and development of knowledge in this educational field, not least in order to inform my own 
praxis as an organ educator. I have taught organ to 75 children since 1993, first in Australia and then in Norway from 1994. In 2010, I established an organ school in Trondheim (Orgelklubben Ludwig) associated with the Trondheim municipal culture school, based upon models already established in Bodø, Bergen and Re in Østfold. In a broader perspective, I have also taught at organ festival seminars for children in Stavanger, Bodø and Trondheim, and have interviewed and observed pioneering pedagogues in Norway (Bjørn Vidar Ulvedalen), England (Anne Marsden Thomas), The Netherlands (Christiaan Ingelese) and Australia (Jennifer Chou). I also contributed to the establishment of a national network of organ pedagogues in 2019 (KIN, 2020). This experience base provides a frame of reference throughout this chapter.

The teaching materials and practices discussed in this chapter have been collected and utilised in my own teaching practice, and reflect Norwegian organ pedagogy for children. Important informal sources also include innumerable personal communications with pioneering textbook authors on method usage and differing pedagogical approaches, and communication with a network of organ teaching colleagues throughout Norway. While a substantial amount of teaching material has been published in Scandinavia, a larger proportion of teaching material exists only as unpublished, locally adapted arrangements, created to fill a particular teaching need.

A variety of means have been used to find previous published research in this field. Multi-language searches (Scandinavian, German, French and Dutch languages) were carried out in online databases, including Oria and ERIC. The search terms included combinations of keywords "organ" and "pipe organ" as denominators, with the addition of variations, such as "music", "pedagogy", "method", "teaching" and all known textbook author names. Google Scholar was used as a supplementary source. The few relevant results found were related to historical or performance practice-related studies, teaching philosophies, motivation and structural parameters in instrumental teaching, learning strategies and self-regulation of practice and performance (Nielsen, 1998; Steyn; 2009; Kvislen, 2011; Steyl, 2018) as well as on teaching materials in organ education (Kvislen, 2011; Steyl, 2018; Steyn; 2009). A few studies focusing 
on organ tuition practices for children were also found; one examining the Suzuki teaching method in organ teaching for children (Steyn, 2009), another considering how teaching content and teaching organisation influence young pupils' interest and motivation (Kvislen, 2011) and a third examining the challenges imposed by prerequisite piano skills on established educational methods for organ (Steyl, 2018). These studies were then examined with reference to relevancy to organ education for children, and factors related to how teaching materials, philosophies and practices influence motivation to play the organ, including choice of instrument, and how socio-religious and socio-cultural factors may influence and challenge the existing framework for organ schools.

As teaching materials are an important parameter in disseminating teaching practices, textbook studies within instrumental education in general are highly relevant. Examples include Blix' study about textbook content for beginner instrumental students (Blix, 2018) and Rostvall and West's (2001) study of interaction and learning in instrumental teaching in Sweden. Furthermore, considerable research has been conducted on one-to-one instrumental teaching as such (e.g. Burwell, 2013; Calvert, 2014; Johansson, 2013; Watson, 2010) and not at least concerning piano teaching (Chmurzynska, 2012; Leikvoll, 2017; Siebenaler, 1997; Speer, 1994; Thomas-Lee, 2003). Nevertheless, basic parameters such as questions related to keyboard proficiency as a prerequisite to organ education, remain unaddressed in peer-reviewed studies.

To the best of my knowledge, which is based upon published studies and personal experience, organ education for children (6-14 years of age) is not yet established as an explicit research area within the field of music education research. Organ education has specific and unique parameters, and studies in instrumental teaching practices are typically instrument-focused. The few studies pertaining to teaching organ to children (Kvislen, 2011; Steyl, 2018; Steyn, 2009) broadly relate to teaching philosophies, motivation and framework factors, as well as to organ methods and other teaching materials included in the present discussion. Framework parameters (including physical and psychosocial issues, as well as learning environments) point to an area which requires further evaluation, and structural factors, such as how organ teaching for children is 
organised and contextualised, remains unexplored. Some are obvious: for example, there is a dearth of didactic organ teaching materials for teachers, and the availability of organ tuition and, thus, practice access is not regulated in Norway. The importance of supportive teaching environments is well-documented (Skaalvik \& Skaalvik, 2014, p. 222); little is known about the teaching environments in early organ education. Whilst formal competencies vary amongst organ teachers in Norway, high levels of practical experience and motivation indicate a vital and active educational field. This chapter does not evaluate current teaching practices or structural challenges in the field, as empirical data on a wide range of parameters in this educational field is lacking. These parameters also include information on student ages, gender, previous musical knowledge, geographical location, cohort size and motivational factors associated with instrument choice. Likewise, little is known about formal and informal teacher competencies, experiences, teaching facilities and teachers' use of textbooks and methods. This comprehensive outlook is necessary in order to contextualise this educational field within instrumental music teaching and to enable the identification of areas in which tensions in framework factors call for further evaluation and revision.

\section{Part 1 - Organ Educational Materials in use in Norway}

The traditional gateway to learning the organ, which is also reinforced through available teaching materials for adolescent and young adult students, requires the student to first gain experience and proficiency on another keyboard instrument (usually the piano). When at an appropriate technical level and physical height as a teenager, the student might commence at the organ (Sanger, 1990). The first textbook that challenged these assumptions was published in 1990 (Sanger, 1990). These assumptions, which incorporate a number of preconceptions about the accessibility of the instrument (reaching the pedalboard and playing aids requires a certain minimum physical height), student maturity and compatibility, have been challenged (Steyn, 2009), and a change in international practice in organ pedagogy is in progress (Rönnberg, 2020). 
A substantial body of organ educational materials directed towards adolescents and young adults has been published internationally. A comprehensive overview and evaluation of this material has not been completed and is outside the scope of this article, although some of these educational materials have been examined in academic studies (Steyl, 2018; Steyn, 2009). Organ educational materials for children without previous keyboard experience have a more recent development history. Practical resources to overcome physical hindrances are widely available in Norway (Ulvedalen, 2020a) and have been in use since the early 200os, allowing children to play the organ (with pedals) from the age of around 4 years. These tools include fitted pedal blocks, which may be placed over the relevant pedal keys in use (a two-fold advantage ensues, as only selected keys are made available), adjustable benches (both lower and higher than standard) and adjustable pedalboards, which may be raised or lowered. Suzuki organ teachers in Sweden have also pioneered the use of auxiliary pedalboards, which may be placed atop standard-sized organ pedalboards (Rönnberg, 2020). To date, three comprehensive teaching textbooks for children have been published internationally, all from Scandinavia. These publications are based upon perceived practical teaching needs, informed by feedback from a network of pedagogues in direct contact with one another. Collaboration between pedagogues may also inform future publications, including a proposed database of organ compositions for children. ${ }^{1}$

Whilst textbook development work is also ongoing in several European countries (Ingelse, 2006-2018; Kumpe, 2020; Wegele, 2019) and the USA (Leupold, 2013), Scandinavia appears to have a central position measured by the number of published teaching materials (Rönnberg, 2020; Ulvedalen, 2020a). A systematic review of the publication history of these teaching materials has been undertaken by the author. The first educational publication (Rönnberg \& Hagström, 2006) for teaching children to play the organ is based on the internationally recognised Suzuki method. Its development may be traced back to 1998, and since then, the

1 A collaborative database of facilitated teaching works for children is scheduled for online access in the first half of 2021. This project is a cooperation between instigator and composer Bjørn Vidar Ulvedalen and publisher Norsk musikforlag. The author is the editor of this database. 
series has been expanded to eight volumes (Rönnberg \& Hagström, 2018). Whilst focusing primarily on cognitive teaching strategies, the Suzuki method has also influenced Anne Lise Lindberg Sjödin's (2009-2010e) series Orgelpuls in Sweden, numbering six volumes. Lastly, Bjørn Vidar Ulvedalen's pioneering work in establishing organ teaching for children in Norway in Holmestrand has resulted in a substantial publication list since the first three volumes of the Preludium series were published in 2009 (Ulvedalen, 2009a-2020b). Furthermore, repertoire collections and commissioned works for children have also been published in Norway, Sweden, Denmark (Bryndorf et al., 2019; Kristiansen, 2015) and Finland.

Several textbooks that require previous keyboard knowledge, including Mats Åberg's (1997) Orgelskola, have been published by Scandinavian pedagogues. Aimed at the inexperienced student, previous piano studies are considered prerequisite. However, as a beginner's book, it provides comprehensive instructions on methods of tone production, articulation, accentuation, phrasing, ornamentation, dissonance treatments, cadences and figured bass treatments, fingerings and footings and the coordination of hands and feet. Tomas Willstedt's (1996) Orgelimprovisation provides a philosophical and aesthetic approach to improvisation, leading the student through phonetic, kinematic, dynamic, quantitative and qualitative approaches to creating music at the organ. A more recent textbook in teaching improvisation is found in Ulsrud (2018). Although these materials provide insights into several understandings of organ pedagogy, they remain unexplored in textbook studies. Moreover, their influence on textbooks for children is unknown.

The publication history of organ teaching materials in Scandinavia indicates that the development of this educational field in the region has been person-oriented, led by a small number of pedagogues at the turn of the millennium (Rönnberg, 2020; Ulvedalen, 2009a). Teaching centres in Norway were initiated not by municipal Community schools of music and art (CMSA), churches or other public institutions. Rather, teaching organ to children started as a localised, unofficial activity led by a handful of pedagogues who identified a need to secure the organist profession for the future whilst simultaneously disseminating their own enthusiasm for the organ to children. (Rönnberg, 2020; Ulvedalen, 2020a). Today, it 
remains a grass-roots movement, relying on local interest and sporadic, decentralised support mechanisms. Thus, organ educational materials are primarily private initiatives and are not linked to educational institutions. Some CMSAs in Norway have offered organ tuition for children since the 1990s, including Bodø (1995) and Trondheim (2006).

\section{Part 2: Organ Schools as Teaching Frameworks and Motivational Environments}

The efforts of pioneer pedagogues have collectively contributed to building the foundations of a flourishing educational field with a strong recruitment base throughout the country. An increase in the number of students, active teachers and organ schools (or orgelklubber) has occurred yearly since 2004. Bjørn Vidar Ulvedalen has suggested that at least 500 children under the age of 15 years are involved in organ teaching programmes in the Nordic region (Ulvedalen, 2020a). Interest in music education amongst graduate students has also increased. Eleven students have completed the practical-pedagogical education (PPU) course at NTNU since 2013, adding to their bachelor education in church music an education programme in organ pedagogy for children. A similar programme exists in Oslo at the Norwegian Music Academy. Currently, over 200 children (aged 17 and under) are involved in organised teaching programs in Norway (Bjerke, 2020). More than 40 organ pedagogues with at least one student are currently active and 16 organ schools (orgelklubber) have been established since 2004, when the first orgelklubb was established in Bergen (Orgelklubben Ferdinand, n.d.). A wide variety of teaching materials are in use, both published and informal. Three organisation models are currently found: the municipal CSMA (kulturskolen), parish councils (menighetsråd) or corporate parish councils (fellesråd) and privately organised teaching. A study of the professional understandings of the teacher in municipal CSMAs has been undertaken (Angelo, 2015). CSMAs, which constitute local centres in music and arts education, relate to both community and professional music and arts. Links between schools and kindergartens exist, although CSMAs are primarily extra-curricular. CSMAs are required by Norwegian law (Musikk- og 
kulturskoletilbod, 2011) to serve as local resource centres, and are regulated by set framework parameters (Norsk kulturskoleråd, 2016). As noted by Angelo (2015), few formal guidelines exist to regulate CSMA teacher competencies, curricula and teaching subjects. The CSMA model is utilised in the organ school Orgelklubben Ludvig in Trondheim, which is led by the author.

\section{Orgelklubben Ludvig}

International research shows that the teacher-student relationship is of vital importance for student motivation and is relevant both in practical pedagogy as well as a research study area (Federici \& Skaalvik, 2013, p. 62). This relationship is of particular importance in assessing the impact of the organisation models used in organ teaching and should be a parameter in future research. The organ school in Trondheim, Orgelklubben Ludvig (OKL), was founded by the author in 2010. ${ }^{2}$ It typifies larger organ schools for children in Norway and thus provides an example of Norwegian organ school structures, practices and intentions. The OKL was formed six years after the first formalised organ teaching school for children in Norway. Its formal articles of association state that it is a nonprofit association for the promotion of good teaching and fellowship for young organists in Trøndelag based on an open and ecumenical system. Largely funded by the Trondheim CSMA (Trondheim kommunale kulturskole), the OKL is associated with the Corporate Ecclesiastical Council (Kirkelig fellesråd $i$ Trondheim, KFiT, Church of Norway) in Trondheim, the Diocese of Nidaros and the Ung kirkesang, the national umbrella choir and organ support society for children.

2 Orgelklubben Ludvig is named after two significant musicians from Trondheim. Ludvig Mathias Lindeman (1812-1887) was the most prominent member of a musician family, which made their mark on the Norwegian music scene for over 200 years. Born in Trondheim, L. M. Lindeman worked as an organist, composer, educator and folksong collector. Lindeman founded the first organ school in Christiania in 1883. Ludvig Nielsen (1906-2001) was born in Oslo. He was a composer, choirmaster and cathedral organist at Nidaros Cathedral in Trondheim from 19351976. Nielsen is considered the initiator of the St. Olav Festival in 1963 and was a teacher at the Trondheim Music School and the Norwegian College of Education. Both Ludvig Lindeman and Ludvig Nielsen had a significant influence on church music in Norway. They are thus considered well-suited as role models for Orgelklubben Ludvig. 
The primary articulated aim of the OKL is to provide a church music environment for young people aged 7-20, in a setting which supports, inspires and encourages young organists. Such an aim includes teaching young people how to utilise and enjoy the possibilities latent in organ music and organ playing. A secondary aim is to foster interest in the church musician profession. Individual half-hour lessons are given weekly, which are organised through Trondheim municipal culture school. The students meet as a group six times a year. A variety of activities, such as teaching seminars, masterclasses, organ safaris, concerts and social events, are included in these meetings. Churches provide a regular and important venue for concerts, along with valuable participatory roles in services and other activities. All students are actively encouraged to participate often in church services, which provide regular experience in real performance situations, including congregational accompanying roles. The active role of the congregation also provides a motivational factor wherein progress is followed and support given. Therefore, the core elements in teaching include improvisation as well as hymn playing and hymn introductions for church services. No repertoire restrictions are made; if no appropriate repertoire is known, works are chosen from the interests of the individual student and then appropriately arranged for their technical and musical strengths and weaknesses. A total of 18 students are currently enrolled (2020). A waiting list (25 students) indicates robust demand. Assessing the role and impact of the organ school network, organ festivals, commissioned works and structural support models (financial and immaterial) must also be accounted for in future research. Foundations for research have already been laid, through the national Network for organ teachers (NFO), founded in 2019.

\section{Nettverk for oralpedagoger/ Network for organ pedagogues}

Network-building for organ teachers in Norway through interactions among organ schools, organised seminars and other meetings occurs regularly throughout the country. This interaction is coordinated through the recently formed national Network for organ pedagogues (NFO), a network association for everyone who teaches organ in Norway. Its aim is to 
strengthen and consolidate long-term efforts to increase interest in playing the organ amongst children and adolescents. The NFO aims to help teachers by providing a common base for the exchange of ideas through seminars and the development of educational methods and tools, thus strengthening cohesion in work as an organ teacher (KIN, 2020). The network provides an ideal basis for structuring future research projects through seminars, conferences and questionnaires, which may be structured to provide empirical data on current instrumental teaching practices for children.

\section{Part 3: The Evolving Field of Instrumental Music Pedagogy}

Instrumental music pedagogy is a complex research field; hence, it is necessary to place teaching within different theories and practices alongside a wide spectrum of individual, objective and contextual relationships. Studies that have been carried out highlight educational issues related to textbooks and learning views as well as motivation and structural frameworks. These studies also reflect a lack of research on general organ teaching, which is related primarily to a paucity of empirical and qualitative data. Such data can provide the basis for studies on the use of textbooks, teaching content and efficiency and organisational models. The following paragraphs describe and categorise relevant studies, which are essential to build upon.

Educational material research is evolving (Blix, 2018); it is a field whose findings have important transfer value to organ education. In this context, I discuss the knowledge and learning views, aesthetic relevance and the role of textbooks in music education. Important works have been done in this area by (amongst others) Hilde Blix. Blix's research concentrates on the position of the textbook in the Norwegian school system and on the state of instrumental music teaching, where the textbook itself often has great defining power. Her research article (2018) reviews textbooks for instrumental students at the beginner level in terms of concepts of dialogue, authority and critical awareness. Blix' study is motivated by findings indicating that teaching in the Nordic countries, including in music, tends to be teacher-controlled. As Blix points out, this implies 
that teachers should have good knowledge of what characterises good textbooks, and that the traditional focus on cognitive learning should be challenged (Blix, 2018) and balanced through dialogue-based teaching materials and practices. In the context of the organ teaching materials, this challenge can be met especially through the master-student approach or apprenticeship teaching, where activities are informed by teacher demonstration, imitation and common practices, all built upon the dialectic dissemination of handcraft traditions. Anders Rønningen's study (2010) and doctoral dissertation (Rønningen, 2015) provide justifications for why music education cannot be placed independently of cultural, structural and philosophical issues, thus having particular relevance for the field of organ education, which primarily takes place in buildings and situations with an overt ecclesial context.

\section{Learning Strategies in Organ Education}

A seminal Norwegian doctoral dissertation (Nielsen, 1998) discusses learning strategies in the context of instrumental music education. This work examines how two advanced music academy organ students successfully self-regulate their use of learning strategies within practice sessions. This dissertation provides insights into how advanced students plan, regulate and adjust their organ practice according to set goals, i.e. performance. Such a system is based on verbal reports and videotaping practice sessions. A finding indicates that the students gain extensive self-regulatory skills, which enable them to optimise their learning and performances, involving interpersonal, contextual and intrapersonal conditions. Through specific goal-setting, the students are able to plan strategically using self-instruction and task strategies whilst simultaneously monitoring and evaluating their learning processes in detail. An implication shown in this dissertation is that advanced students demonstrated skilful, complex and cyclic self-regulatory learning. The specific demands of organ education and its implications in practice strategies is of particular interest for future studies on the learning strategies of children, given that learning strategies of children and adults differ significantly, and especially so when children themselves take teaching tasks (Ellis \& Rogoff, 1982). The learning model explicated in this dissertation, 
together with an overview of earlier research into practice theory and task management, makes this dissertation relevant to this discussion.

\section{Instrumental Teaching Textbooks Past and Present}

Although Nordic studies on instrumental teaching practices have been undertaken, these are of older date and mainly emphasise pedagogy related to cognitive skills, such as note-reading, in addition to technical skills (Blix, 2018). A doctoral dissertation (Rostvall \& West, 2001) used critical discourse analysis of Swedish instrumental music textbooks for beginners to demonstrate the need to discuss student-teacher interactions. Furthermore, it finds that critical awareness, creativity, aural awareness and musicality must be essential elements of the pedagogy of today. These factors have been found to be absent in the analysed textbooks. The above-mentioned studies show that textbooks have an important position in teacher and student consciousness and that language use (including gender equality, inclusion and multicultural awareness), presentation, illustrations, progression, music vision and philosophy and repertoire choices, to name just a few parameters, are relevant assessment topics. Blix (2018, p. 52) notes that, in her experience, young students are rarely critical of the content of the textbook, and they tend towards perceiving textbooks as indisputable sources of knowledge. In addition, teachers who use this type of cognitive teaching tool, wherein goals, activities, concretisations and progression are all incorporated into the same tool, may be assumed to accept the content of the textbook. Thus, it may reinforce the students' perception of the textbook's position, in that it can shape teaching and homework and provides a hermeneutic transfer to the students that is considered normative. My own instrumental teaching experience over the past 25 years reinforces the validity of these points, and I know no organ teacher who relies on one single teaching material source without supplementing it with their own materials.

\section{The Dialogue-based Textbook}

Blix suggests a follow-up study in order to map out how textbooks are used in CSMAs and private education at the beginner level. Such a study could provide insights into how the student-teacher dialogue may be used to build 
an interaction rapport between the teacher and student. The students' own interests would then provide the basis for a dialogue-based, contextualised and conscious pedagogy, which reduces reliance upon set cognitive tasks (Blix, 2018, p. 59). Blix also remarks that score arrangement, score flexibility and improvisation, which are all highly relevant for organ teaching and indeed for all instrumental teaching practices, are absent in the textbooks that have been examined. Music works in the textbooks studied may thus be interpreted to have been reduced to fixed, comprehensible quantities, wherein room for interpretation, flexibility and ambiguity is limited. This finding also reflects my own experiences using the three Scandinavian organ textbooks available. Although some textbook authors do actively encourage the teacher and the user to use the contents flexibly based on the capacity of the student, this flexibility is rarely fully explicated.

These studies demonstrate that the textbook - as a research object provides valuable insights into how an instrumental method is interpreted by the various authors. Such parameters as varied learning methods as well as cultural and social issues, together with the provision for the student's own interests in collaborative learning and free expression, can enhance the value of the textbook, whilst simultaneously reducing the student's notion that the textbook itself holds a position of authority. In providing several content forms, including dialogue-based teaching, cognitive tasks as well as flexibility and improvisation tools, a teaching textbook can expand both student development and increase the range of teacher tools. These factors may assist the accessibility of the textbook for children who do not enjoy solely cognitive tasks, but are more oriented towards collaborative learning and constructionism or free expression, both of which are highly relevant to organ performance traditions.

\section{Part 4 - Early Organ Pedagogy as a Field of Research}

\section{Hanne Solveig Kvislen's Motivation Study}

A master's thesis by Hanne Solveig Kvislen (2011) considers ways in which teaching content and teaching organisation may increase interest, and thus motivation, amongst children and adolescents learning the organ in 
Norway. Her study uses qualitative analysis of interviews with two teachers and 11 students at two organ schools. Kvislen reflects on student motivation based on framework factors and teacher and student assumptions and qualities. She also focuses on how instrumental support mechanisms may be used to promote a didactic viewpoint. Kvislen's study is securely placed within the established Norwegian didactic relationship model (Bjørndal \& Lieberg, 1978), which is commonly used (Hanken \& Johansen, 1998, p. 198) as a basis for assessing what may lead to good teaching practices and results. In this model, in which all the factors are linked together because they are interdependent, dynamic didactic improvisation is assumed as an integral part of the teaching practice, precisely because not all parameters can be predicted in advance of a teaching lesson. Kvislen's own reflections are focussed upon external material and are not related to personal teaching experience.

The two organ schools referred to in Kvislen's study use similar models to support social interaction. This important parameter influences motivation and is especially evident where organ students belonging to orgelklubber or organ schools form a social community when they meet and get to know one another through a common teacher as well as common teaching areas, goals and performance situations (Federici \& Skaalvik, 2013, p. 62). For Kvislen, Bjørn Vidar Ulvedalen's Organ school in Re, Holmestrand and Orgelklubben Ferdinand in Bergen are two important informant groups. As Kvislen's thesis is based around these two environments, the two textbooks associated with Re and Bergen, Bjørn Vidar Ulvedalen's Preludium Volumes 1-5 (2009a-2010b) and Amund Dahlen and Bjørn Sortland's Ferdinands orgelbok (2008), are also discussed.

Key facets of the Norwegian organ school model in Kvislen's study include teaching environments, social and musical interactivity and performance arenas. All of these collectively create a unique model for teaching practices associated with Lev Vygotsky's principles (Bråten, 2005). Kvislen also recommends teaching based on an extended form of the Scandinavian MAKVIS principles for a good learning environment, arguing that the application of Vygotsky's learning theory based on the student's own intentions and interests is an important factor in effective and motivated progression. Her conversations with students reveal that 
choosing one's repertoire had a bearing on how much work they put into practice (Kvislen, 2011, p. 86). These findings are also demonstrated in my own teaching praxis, although these factors require testing through quantitative empirical data.

Furthermore, Kvislen draws on the personal praxis of Bjørn Vidar Ulvedalen, who asserts that communities around music making can strengthen and affirm both the child and the teaching practices (Kvislen, 2011, p. 72). This is confirmed by international research, which is described inter alia in Roger Andre Federici and Einar M. Skaalvik's study, which lists many international studies, involving Hattie's controversial meta-analysis (Hattie, 2009) showing how social support (i.e. the processes that contribute to the student's academic and social development) works from the student's own standpoint. Nevertheless, research shows that the teacher is the single most important factor behind a student's motivation (Federici \& Skaalvik, 2013, p. 58). In Kvislen's study, dedication, competence and humour are found to be good motivational qualities in the teacher.

Various forms of social support have been identified in the axis between emotional (encouragement, acceptance and appreciation) and instrumental (advice and guidance) support and the correlation between them (Federici \& Skaalvik, 2013, p. 58; Sprikut, 2017). Less obvious, but perhaps as challenging, are findings showing that the student may achieve a strengthening of solidarity and personal relationships with his/ her peers precisely due to common teaching practices. In this context, a study assessing how affiliation and social support in the orgelklubber may affect student motivation, repertoire selection and practice would provide valuable information on how this type of composite pedagogy works, especially as most orgelklubber include students within a wide age range. In so doing, such a study could also examine how group teaching functions concurrently at differing levels, ages and competencies. Research also shows that the need for emotional support and belonging is as great in secondary school age as it is in the past (Federici \& Skaalvik, 2013, p. 62). Retaining the same teacher through a 10-year career in an orgelklubb may also provide room for strengthening possible learning outcomes over time, precisely because one can maintain correspondence 
between the teacher's time and the student's learning outcomes (Federici \& Skaalvik, 2013, p. 62).

\section{The Church as a Motivational and Structural Parameter}

Organs are predominantly found in religious spaces. For some students, this factor may cause distancing and non-engagement with the instrument. None of the Scandinavian organ education textbooks consider the basis for this type of distancing. Kvislen argues that such disadvantages may be offset by other teaching-related motivational factors (2011, p. 85). This is debateable, as the location of teaching can create distancing. For Kvislen, and in my own praxis experience, the placement of the instrument in church is advantageous, as it provides good opportunities for practice and performance in both religious services and in other contexts (Kvislen, 2011, p. 93). The learning environment within the church itself, with the Norwegian church's own religious education reform (trosopploeringsreform) as a backdrop, is not discussed by Kvislen, but would be a stimulating and useful way of linking the field to a religious teaching context, as has been done in Germany in relation to the teaching of singing to children in church (Tenbergen, 2020). Here, one might discuss influences from the church's physical, theological and psychological frameworks. Central to teaching in an ecclesial context are preparations for the liturgical action. Presence and active participation are regarded as primary goals. In addition, the silent dissemination of various religious parameters can affect understandings of piety, moral foundation, liturgical awareness and social support. It is reasonable to believe that these can inform and influence contextual musical communication (Tenbergen, 2020).

All organ textbooks published for the purpose of teaching children to play the organ include hymn tunes and other liturgical accompaniment tasks. Thus, the possibility of wholly secularised organ teaching has not been addressed in educational materials or in research literature. Organ teaching in a secular context must relate primarily to social participation and preparation for concert performances as well as the dissemination 
of public culture. This shows a multi-dimensional didactic starting point in both secular and religious contexts. Music has features and functions that exceed performance goals; what is communicated is always richer in content than the constituent parts might indicate. Music education will always have elements of the subjective and objective in its inputs; these could be supplemented by a religious dimension. However, it is the context that will determine how one might proceed. The liturgy does not exist for organ students to participate in it. Rather, the organ student places him/herself in context. The liturgy provides the basis for how to determine the repertoire, how to learn it and how to convey it. Questions that relate to how ecclesial and secular environments impact the students' motivation and their identification with the instrument need to be addressed in further research.

\section{The Instrument as a Motivational Factor}

Studies that investigate student motivation in choosing which instrument they identify with and why students commence and continue with instrumental teaching have been conducted (Chmurzynska, 2012; Crowther \& Durkin, 1982). Harrison and O’Neill (2003) investigated some of the parameters of choice related to gender and gender stereotyping in the choice of preferred musical instrument amongst children who did not learn an instrument. They reveal important findings that children's judgements may vary according to the domain examined and that familiarity and experiences play a vital role in such a process (Harrison \& O’Neill, 2003, p. 399). These motivational factors are relevant to learning any instrument.

No studies are known to have investigated why students choose to play organ as an instrument, although hearsay and experience-based praxis provide some useful indications. Motivations derived from the nature of the organ, such as its monumentality, volume, technical controls, design, sound (that swaddling, magnificent and transcendent sound that attracts all children), flexibility, repertoire, "otherness" and location (and therefore ecclesial nature) have not been evaluated either. Nevertheless, Kvislen believes that the sonic characteristics of the pipe organ are of great 
importance for student motivation (Kvislen, 2011, p. 94). She speculates that this may be related to a need to satisfy musical power, thus highlighting the need for further research.

Motivation derived from organ music itself (known and unknown) is also an important area that remains unexamined. In my own experience, the concept of what is considered organ music repertoire is unclear for many students. How organ repertoire is formed, its performance history and the teacher's role as a performing musician all play a part in consolidating students' motivation. Listening and choosing the repertoire together with the teacher is a form of collaborative learning, wherein social support is combined by mutual discoveries from different fields of view.

Kvislen's thesis provides an introductory guide to how students and teachers interact in different contexts to motivate organ playing. There is a need to test her findings as well as those of others in a larger empirical study. In relation to this, the Network for organ teachers in Norway can potentially provide a valuable comparative context and forum for such a study. A quantitative study of all current students in Norway could provide valuable materials with which to inform and develop both educational practices and recruitment efforts within employment fields.

\section{Research Into Early Organ Pedagogy}

Current research provides little information on the teaching materials used and on how organ teaching for children and adolescents works in practice. Some works have been conducted on the transfer of teaching methods for adults to children and on how piano teaching pedagogy has been transferred to beginners at the organ. Marian Steyl's comprehensive master's thesis (Steyl, 2018) discusses problems related to established instrumental methods for the organ, which place piano skills as a prerequisite, and compares these with methods for beginners without keyboard experience. Steyl's hypothesis, which is informed by a South African context, tests and challenges the accepted notion that organ playing should be based on established piano playing skills and 
that organ tuition should only commence on the attainment of a specified bodily height. Her basis of comparison are four organ methods for students with keyboard experience: Peeters (1953), Gleason (1996), Ritchie and Stauffer (200o) and Thomas (1997). She draws a basic comparative analysis of four organ methods for beginners: Sanger (1990), Deis (2003), Ingelse (2006) and Rønnberg and Hagström (2006a). Steyl's research question is broad: "Are there effective beginner courses for organ learners designed specifically for the needs of those with no previously acquired keyboard skills, and are these courses comprehensive in their approaches to the development of a sound keyboard and organ technique, as well as other skills required by instrumental music?" (Steyl, 2018, p. 2). This question is tested through a comprehensive overview of what constitutes basic keyboard skills and how best they might be acquired. In answering her question, Steyl also queries whether it is rational to start organ teaching at the organ or at the piano in order to establish good keyboarding skills. Steyl is unable to state conclusively that organ technique is best gained without previously attained keyboard techniques. Subsequent questions posed by Steyl relate to defining good organ techniques, establishing organ techniques in students with piano skills, how piano methods establish good technique and how available organ textbook resources for beginners relate to the needs of beginner students.

\section{Technical Demands in Organ Playing}

In order to draw conclusions on current practices in the field of education internationally, Steyl lists specific organ playing needs through a brief description of the technical demands involved in playing the organ. These not only include body height, instrument characteristics and key weight, but also various opinions on performance practices, including habitus, touch, articulation, fingering and footing (pedalboard use) as well as registration and console techniques. She makes a clear distinction between piano playing and organ playing skills. Transfer value is also found in her description of different teaching strategies for piano educators (p. 99); here, she focuses on associationism and cognitive learning, on 
various established methods for communicating concepts to the student and on descriptions of four organ textbooks, based partly on the teaching strategy descriptions for piano methods. Rønnberg's (2006a) approach is described by Steyl (pp. 158-160) as a rigid, teacher-dependent method. This criticism concerns an absence of student autonomy and independent conceptualisation as the learning takes place through imitation and in a set order, thus reducing the possibilities for student-led dialogue into learning strategies.

Steyl's thesis unsurprisingly confirms that the organ textbooks of Sanger, Deus, Ingelse and Rönnberg contain valuable contributions to the field. She further believes that each will suit different student types and that each method requires careful instruction by a trained teacher. Ingelse and Rönnberg's textbooks are considered better suited to the younger child, although serious progression, autonomy and repertoire challenges are identified. Steyl (p. 164) points out that such major shortcomings may not be apparent to pedagogues. She concludes her work by stating that organ pedagogy can benefit from recognising the possibility of beginning keyboard study at the organ. Furthermore, she recommends that planning and designing the learning process should by clarified through the use of selected psychological and pedagogical principles and through a broad overview of the development of musicality and technique.

Steyl's thesis is partly reliant on an earlier doctoral dissertation (2009) by Adriaan Hermanus Steyn, who also addresses the use of the Suzuki teaching method in organ teaching for children. Steyn evaluates the methods found in several published textbooks aimed at students who start without previous keyboard instrument experience. He then examines the Suzuki organ method as an approach which both eschews previous keyboard experience, and requires no reading skills. He concludes that through this method, the organ is made more accessible for younger organists. An important finding in his dissertation is related to physical coordination, which seems to be significantly enhanced in younger students who start organ teaching early (Steyn, 2009, p. 168). Peter Hurford (1990, p. 40) describes the need for coordination practice in his book Making music at the organ: 
The mastery of any musical instrument requires a high degree of mental and physical co-ordination. For a keyboard player, the understanding and subsequent projection simultaneously of several lines of music, each with its own articulation and phrasing, adds to co-ordinative problems a dimension unknown to other performers. For the organist, who must often share several contrapuntal lines not only between ten fingers but with his feet as well, the degree of co-ordination required is greater than for any other musical performer (or indeed for any other occupation known to me).

By reviewing how cognitive, physical and emotional development affects younger children during organ teaching, Steyn investigates what methods may be used to make the organ more accessible to the younger child. These findings are chiefly related to research previously done on the Suzuki method and are not qualified through empirical data related to organ education. There are no empirical data in Steyn's thesis that support the Suzuki method's practical application in organ teaching. Neither has Steyn tested the effectiveness of the Suzuki method or its relevance to learning skills and motivation amongst organ students in South Africa. Nevertheless, Steyn's study provides valuable insights on how organ methods adapted to different developmental stages of the child may play a significant role in teaching outcomes (Steyn, 2009, p. 168).

\section{Leaping Forward: Development, Possibilities and Challenges}

This article has established that organ teaching for children in Norway is a vital and continuously developing educational field - one that is linked to parallel developments in the Nordic region and further afield. The broad mapping of the field's framework factors and praxis in this article, along with the establishment of critical links to tangential and parallel research studies, is intended to inspire further development in this important field. Beginner organ education for children and young adolescents has been tested internationally over the past 15 years, and Scandinavian pedagogues are considered to have had a pioneering role in this area. The studies investigated in this article and the personal teaching praxis in 
Norway indicate that keyboard skills are not prerequisites for organ education. The ready availability of physical aids, which enable children to play on adult-sized instruments, also indicates such a paradigm change. Organ schools have been established in the Nordic countries during the past two decades, and a steady increase in the number of pupils from year to year indicates a thriving field, wherein many challenges have been encountered and resolved. The existing studies discussed above indicate that there is a significant need to further elucidate the field through targeted research. I identify five central areas hereunder:

\section{A general field study of today's teaching practices in Norway is needed to map central didactic implications of childhood organ education}

Continuing empirical and qualitative research on teaching procedures and the influence of external framework factors (such as organisational models, teaching goals and ecclesial involvement) affecting the teaching situation is necessary in understanding the process of developing guidelines for facilitating teaching techniques and methods for teaching children to learn the organ. Such studies must include framework factors, learning views and educational practices; an understanding of how textbooks are used; and whether there are shortcomings or needs that are not yet covered. This will assist in informing how teaching takes place and how it is influenced by socio-cultural factors (ecclesial, secular and societal) and their latent interacting relationships.

\section{Investigations into the motivational factors that influence children to commence and continue playing the organ}

Little is known about why children are motivated to learn the organ. Hence, responses related to motivation and music teaching philosophy can also inform how organ teaching might be placed along an axis between the domains of secular and religious performance. The church's many roles, which include facilitating organ teaching positions, practice and teaching access as well as serving as an employer of organists also require further consideration. 


\section{Coordination and motor development studies on how beginners tackle physiological challenges}

The physical (and mental) challenges associated with the organ technique requirements of coordination, touch and motor skills in children have yet to be investigated, although awareness of these requirements has already been articulated amongst some researchers. The assessed methods that have been researched are all based primarily on cognitive learning, wherein the emphasis is on exercise and control tasks. Coordination studies are called for by Steyn, who found that young students who start organ education early on gain stronger coordination skills than their peers who start later.

\section{Investigations into identifying how the organ educator influences the student as a role model and through performance practice and how these factors influence and develop pedagogical practices}

Studies have shown that the role of the master-student relationship, relevant as a traditional organ pedagogical tool, is undervalued in many instrumental teaching textbooks. As an addition to improvisation and interactive accompaniment in a liturgical context, imitative performance practice is a form of dialectic knowledge impartment that requires critical and creative thinking. Through my own experience, I have found that students who are encouraged to experience immersion in these practices (live or online) rapidly gain insights and flexibility skills.

\section{Investigations into organ teaching textbooks and their development}

Factors that can enable the teacher to provide efficient, flexible, collaborative and interpretative guidance to the student require further research. The hermeneutical position and mandate of textbooks, which usually primarily promote note reading knowledge and structure and presupposes a master-teacher tradition, should be challenged and developed. Although not dealt with in the foregoing discussion, examining how digital learning tools might be used in organ teaching is a timely research endeavour. 
Instrumental teaching is never a fixed, comprehensible quantity. In fact, research recommends greater scope for flexible interpretation and less focus on cognitive knowledge impartment in teaching materials. I identify a need to know more about how textbooks might be developed for use in collaborative learning (samskapt loering), thereby raising awareness in the possibilities of pursuing dialogic pedagogy and enhanced student interaction with the teacher. Thus, a primary goal in further research work is to assess experiences related to the flexible use of learning materials. Collaborative learning connects the student and teacher equally in the use of creativity resources. Together with free and planned improvisation, and in combination with cognitive learning strategies, these factors can provide valuable insights that can have general educational transfer value.

Thus, this article calls for quantitative, empirically based research into the implications of organ education as a first instrument of study. Such research would bring further knowledge to the field (including knowledge on processes related to instrument choice, motivation and teaching frameworks and environments) and would assist in identifying factors influencing the international decline in recruitment to church music education programmes. Finally, a greater understanding of the role of childhood introduction to organ playing would inform both education and employment outcomes.

Ongoing research by the author using empirical data gathered though a targeted questionnaire and reflective analysis from active pedagogues registered in the Network for Organ Pedagogues in Norway aims to provide a basis for further articles on teaching practices and conditions in the country. Furthermore, educational materials (including textbooks and organ works for children) published in Sweden, Norway and Denmark provide insights into disseminated teaching philosophies, into how teaching philosophies are presented and established as well as into learning goals, repertoire and theoretical dissemination. In addition, a qualitative research project by the author is in progress which investigates why these educational materials have been published and how method use, structure and content weighting define each publication. 


\section{References}

Angelo, E. (2015). The music educator: Bridging performance, community and education - an instrumental teacher's professional understanding. International Journal of Community Music, 8(3), 279-296.

Bjerke, M. (2020). Rekordmange barn og unge spiller orgel [Record numbers of children and adolescents play the organ]. Musikkultur, (1). https://musikkultur. no/nyheter/rekordmange-barn-og-unge-spiller-orgel-6.54.674221.e83c738884

Bjørndal, B. \& Lieberg, S. (1978). Nye veier i didaktikken? En innføring i didaktiske emner og begreper [New directions in didactics? An introductory guide to didactics and didactic terms]. Aschehoug.

Blix, H. S. (2018). Lærebokas makt: En studie av lærebøker for instrumentalelever [The power of the textbook: A study of textbooks for instrumental music students]. Journal for Research in Arts and Sports Education, 2(2) [Special Issue: Skapende og tenkende - perspektiver på kritisk kunstpedagogikk i skole og kulturliv]. https://doi.org/10.23865/jased.v2.920

Bryndorf, B., Schmidt-Madsen, P., Krogsøe, K., Jakobsen, P. S., \& Matthiesen, M. H. (Eds.) (2019). Pasta, piber og pedaler. Forlaget Mixtur.

Bråten, I. (2005). Vygotsky i pedagogikken. [Vygotsky in pedagogy]. Cappelen Akademisk Forlag.

Burwell, K. (2013). Apprenticeship in music: A contextual study for instrumental teaching and learning. International Journal of Music Education, 31(3), 276-291.

Calvert, I. W. (2014). Investigating the one-on-one master-apprentice relationship: A case study in traditional craft apprenticeship [Doctoral dissertation, Brigham Young University]. https://scholarsarchive.byu.edu/cgi/viewcontent. cgi article $=5153 \&$ context $=$ etd

Chmurzynska, M. (2012). How (not) to discourage youngsters from playing the piano. On bad and good piano teaching. Procedia - Social and Behavioral Sciences, 45, 306-317.

Crowther, R. D., \& Durkin, K. (1982). Sex- and age-related differences in the musical behavior, interests and attitudes towards music of 232 secondary school students. Educational Studies, 8(2), 131-140.

Dahlen, A., \& Sortland, B. (2008). Ferdinands orgelbok. Cantando musikkforlag.

Deis, F. (2003). Orgelschule (2003), Bischoff Verlag.

Ellis, S., \& Rogoff, B. (1982). The strategies and efficacy of child versus adult teachers. Child Development, 53(3), 730-735. https://doi:10.2307/1129386

Ferderici, R. A., \& Skaalvik, E. M. (2013). Lærer-elev-relasjonen - betydning for elevenes motivasjon og læring [The teacher-student relation - aspects of relevence with regard to motivation and learning]. Bedre Skole, (1), 58-63.

Gleason, H. (1996). Method of organ playing ( $8^{\text {th }}$ ed.). Prentice Hall. 
Hanken, I. M., \& Johansen, G. (1998). Musikkundervisningens didaktikk

[The didactics of music teaching]. Cappelen Damm Akademisk.

Harrison, A. C., \& O’Neill, S. A. (2003) Preferences and children's use of genderstereotyped knowledge about musical instruments: Making judgments about other children's preferences. Sex Roles, 49(7-8), 389-400. https://doi-org.ludwig. lub.lu.se/10.1023/A:1025168322273

Hattie, J. (2008). Visible learning: A synthesis of over 800 meta-analyses relating to achievement. Routledge.

Hurford, P. (1990). Making music at the organ. Oxford University Press.

Ingelese, C. (2006). Organ Pleno 1, Muziekuitgeverij J. C. Willemsen.

Ingelese, C. (2015a). Organ Pleno 2, Muziekuitgeverij J. C. Willemsen.

Ingelese, C. (2015b). Organ Pleno 3, Muziekuitgeverij J. C. Willemsen.

Ingelese, C. (2015c). Organ Pleno 4, Muziekuitgeverij J. C. Willemsen.

Ingelese, C. (2015d). Organ Pleno 5, Muziekuitgeverij J. C. Willemsen.

Ingelese, C. (2015e). Organ Pleno 6, Muziekuitgeverij J. C. Willemsen.

Ingelese, C. (2018a). Organ Pleno Plus 1, Muziekuitgeverij J. C. Willemsen.

Ingelese, C. (2018b). Organ Pleno Plus 2, Muziekuitgeverij J. C. Willemsen.

Johansson, K. (2013). Undergraduate students' ownership of musical learning: obstacles and options in one-to-one teaching. British Journal of Music Education, $30(2), 277-295$.

KIN. (Kirkemusikksenter i Nord). (2020). Nettverk for orgelpedagoger. https://kin. no/Hjem/nfo

Kumpe, A. (2020). Die innovative Orgelschule. Andrea Kumpe, Lucerne.

Kvislen, H. S. (2011). Interesseskapende orgelundervisning: en undersøkelse av orgelopploring for barn og unge [Organ teaching which builds interest: an investigation of organ teaching for children and adolescents] [Master thesis, University of Oslo]. https://www.duo.uio.no/handle/10852/26974

Kristiansen, K. I. (2015). Orgelbogen. Forlaget Mixtur.

Leikvoll, K. J. (2017). Listen, write, play: About music reading skills of piano pupils at the beginner level [Doctoral dissertation]. University of Stavanger.

Leupold, W. (2013). Teach the organ! A handbook for organ teachers. https://www. wayneleupold.com/Articles/pdf/teach-the-organ.pdf

Musikk- og kulturskoletilbud. (2011). Lov om grunnskolen og den videregående opplæring [Music and culture school regulatory laws, relating to the education laws for schools, and including upper secondary schools]. https://lovdata.no/ dokument/NL/lov/1998-07-17-61/KAPITTEL_15\#\$13-5

Nielsen, S. G. (1998). Selvregulering av loeringsstrategier under øving. En studie av to utøvende musikkstudenter på høyt nivå [Self-regulation of learning strategies during practice. A study of two advanced level performance music students] [Doctoral dissertation], Norwegian Academy of Music. 
Niiniluoto, I. (2001). Futures studies: Science or art? Elsevier - Futures, 33(5), 371-377. https://www.sciencedirect.com/science/article/pii/Soo163287000008oX

Norsk kulturskoleråd. (2016). Rammeplanen for kulturskolen - Mangfold og fordypning [Framework plan for the culture school - diversity and specialisation]. http://www.kulturskoleradet.no/rammeplanseksjonen/rammeplanen

Orgelklubben Ferdinand. (n.d.). https://no.wikipedia.org/wiki/Orgelklubben_ Ferdinand

Peeters, F. (1953). Ars Organi. Schott.

Ritchie, G. H., \& Stauffer, G. B. (200o). Organ technique: Modern and early. Oxford University Press.

Rostvall, A.-L., \& West, T. (2001). Interaktion och kunskapsutveckling - en studie av frivillig musikundervisning [Interaction and learning: a study of music instrument teaching] [Doctoral dissertation]. Stockholm University. http://su.diva-portal. org/smash/get/diva2:504719/FULLTEXTo1.pdf

Rönnberg, G., \& Hagström, L. (2006a). Suzuki organ school vol. 1, Alfred music.

Rönnberg, G., \& Hagström, L. (2006b). Suzuki organ school vol. 2, Alfred music.

Rönnberg, G., \& Hagström, L. (2006c). Suzuki organ school vol. 3, Alfred music.

Rönnberg, G., \& Hagström, L. (2006d). Suzuki organ school vol. 4, Alfred music.

Rönnberg, G., \& Hagström, L. (2009a). Suzuki organ school vol. 5, Alfred music.

Rönnberg, G., \& Hagström, L. (2009b). Suzuki organ school vol. 6, Alfred music.

Rönnberg, G., \& Hagström, L. (2018a). Suzuki organ school vol. 7, Alfred music.

Rönnberg, G., \& Hagström, L. (2018b). Suzuki organ school vol. 8, Alfred music.

Rönnberg, G. (2020). The story of the Suzuki organ method. https://www.youtube. com/watch?v=AqCmm9BmlrA

Rønningen, A. (2010). Musikkbegrepet som sort boks. Et forsøk på en dekonstruksjon av begrepet musikk $i$ vestlig tenkning, med utgangspunkt $i$ en loerebok $i$ musikk for ungdomsskolen [Music as a black box term. An attempt to deconstruct the term music i Western thought, using a textbook on music for the lower secondary school as a starting point]. Nordic Research in Music Education. Yearbook 12, 81-99. http://hdl.handle.net/11250/172237

Rønningen, A. (2015) Det etniske steget. En drøfting av kulturelt mangfold i pedagogiske tekster for musikk for norsk ungdomsskole [The ethnic step. A discussion of cultural diversity in pedagogical texts for music in the Norwegian lower secondary school] [Doctoral dissertation, The Norwegian Academy of Music]. http://hdl.handle. net/11250/2367236

Sanger, D. (1990). Play the organ: A beginner's tutor. Novello.

Siebenaler, D. (1997). Analysis of teacher-student interactions in the piano lessons of adults and children. Journal of Research in Music Education, 45(1), 6-20.

Sjödin, A. L. L. (2009). Orgelpuls 1, Gehrmans musikforlag.

Sjödin, A. L. L. (2010a). Orgelpuls 2, Gehrmans musikforlag. 
Sjödin, A. L. L. (2010b). Orgelpuls jul, Gehrmans musikforlag.

Sjödin, A. L. L. (2010c). Orgelpuls improvisation, Gehrmans musikforlag.

Sjödin, A. L. L. (2010d). Orgelpuls koraler, Gehrmans musikforlag.

Sjödin, A. L. L. (2010e). Orgelpuls svensk folkmusik, Gehrmans musikforlag.

Skaalvik, E. M., \& Skaalvik, S. (2014). Skolen som loeringsarena. Selvoppfatning, motivasjon og loering. [The school as teaching arena. Self-awareness, motivation and learning] $2^{\text {nd }}$ edition. Universitetsforlaget.

Speer, D. R. (1994). An analysis of sequential patterns of instruction in piano lessons. Journal of Research in Music Education, 42(1), 14-26.

Sprikut, L. (2015). The discovery of music pedagogic culture: Music teaching as communication process [Doctoral dissertation, University of Toronto]. https:// tspace.library.utoronto.ca/handle/1807/71336

Steyl, M. (2018). Organ tuition for beginners without previous keyboard skills: A critical evaluation of four published methods against the background of initial piano tuition and general organ pedagogy [Master thesis]. Stellenbosch University. http://hdl.handle.net/10019.1/103748

Steyn, A. H. (2009). Suzuki-gebaseerde riglyne vir orrelonderrig: 'n kritiese ontleding [Suzuki-based organ teaching for children: a critical evaluation] [Doctoral dissertation (performance)]. University of Pretoria.

Tenbergen, T. (2019). Singen mit Kindern und Jugendlichen im Kontext des Religionsunterrichts [Singing with children and adolescents in the context of religious education]. IAH-Bulletin, 47, 8-24.

Thistlethwaite, N., \& Webber, G. (1998). The Cambridge companion to the organ. Cambridge University Press.

Thomas, A. M. (1997). A graded anthology for organ. In five volumes. Cramer Music.

Thomas-Lee, P. M. (2003). Piano pedagogy for four-and five-year-olds: An analysis of selected piano methods for teaching preschool children [Doctoral dissertation, University of Georgia]. https://athenaeum.libs.uga.edu/handle/10724/21385

Ulsrud, I.-L. (2018). En improvisators betroelser - Lorebok i orgelimprovisasjon [An improvisor's secrets - a textbook on organ improvisation]. Cantando musikkforlag.

Ulsrud, I.-L. (2020). Personal communication with David Scott Hamnes. 25 September 2020.

Ulvedalen, B. V. (2009a). Preludium 1. Cantando musikkforlag.

Ulvedalen, B. V. (2009b). Preludium 2. Cantando musikkforlag.

Ulvedalen, B. V. (2009c). Preludium 3. Cantando musikkforlag.

Ulvedalen, B. V. (2010a). Preludium 4. Cantando musikkforlag.

Ulvedalen, B. V. (2010b). Preludium 5. Cantando musikkforlag.

Ulvedalen, B. V. (2015a). Ung orgelklang 1. Cantando musikkforlag. 
Ulvedalen, B. V. (2015b). Ung orgelklang 2. Cantando musikkforlag.

Ulvedalen, B. V. (2020a). Organisten. Cantando musikkforlag.

Ulvedalen, B. V. (2020b). Personal communication with David Scott Hamnes. 7 February 2020.

Watson, A. (2010). Musicians as instrumental music teachers: Issues from an

Australian perspective. International Journal of Music Education, 28(2), 193-203.

Wegele, U. T. (2019). Orgelschule mit Hand und Fuß. Band 1. Doblinger musikverlag.

Wegele, U. T. (2019). Orgelschule mit Hand und Fuß. Band 2. Doblinger musikverlag.

Wegele, U. T. (2019). Orgelschule mit Hand und Fuß. Band 3. Doblinger musikverlag. Willsted, T. (1996). Orgelimprovisation, Trumph.

Åberg, M. (1997) Orgelskola. Wessmans musikförlag. 


\title{
Bærekraft - lærekraft: Estetiske læringsprosesser gjennom tverrfaglig arbeid $\mathrm{i}$ grunnskolelærerutdanningen
}

\author{
Anne-Lise Heide \\ Norges teknisk-naturvitenskapelige universitet
}

\begin{abstract}
This chapter examines an interdisciplinary research project with the subjects music and physical education. The aim is to investigate and explore aesthetic learning processes focusing on interdisciplinarity in general teacher education. The participants in the study are all pre-service teachers preparing for primary school (grade 1-7) and lower secondary school (grade 5-10). In the project, which I have called "Krømus", the teaching program is based on the curriculums for both music and physical education from the Norwegian Directorate for Education and Training. Here, the students explore and create rhythmic compositions with body percussion and sports objects, such as basketballs and other props used as instruments. Dancing, sports movements, and voices are also used as compositional elements and the students create a performance together at the end of the workshop. The current curriculum changes in Norwegian primary and secondary education (Fagfornyelsen, LK20) focus on deep learning together with experimentation, exploration and creative processes, and these are guiding educational principles that also provide a foundation for this chapter.
\end{abstract}

Keywords: interdisciplinarity, music, physical education, exploration and creative processes

Sitering av dette kapitlet: Heide, A.-L. (2021). Bærekraft - lærekraft: Estetiske læringsprosesser gjennom tverrfaglig arbeid i grunnskolelærerutdanningen. I E. Angelo, J. Knigge, M. Sæther \& W. Waagen (Red.), Higher Education as Context for Music Pedagogy Research (s. 167-191). Cappelen Damm Akademisk. https://doi.org/10.23865/noasp.119.ch7

Lisens: CC BY-NC-ND 4.O. 
Fagfornyelsen av Kunnskapsløftet (LK20) griper inn i skolehverdagen i Norge fra høsten 2020. Lærere og lærerutdannere har lenge fulgt utviklingen av nye læreplaner på Utdanningsdirektoratets nettsider, respondert på høringer og forberedt seg på ulike vis. I grunnskolelærerutdanningen er det produsert nye emneplaner som ivaretar nye kompetansemål og verdier, og kommunene har satt i gang kompetansepakker for å støtte implementeringen av LK20. Regjeringens strategiplan for skaperglede, engasjement og utforskertrang (Kunnskapsdepartementet, 2019) fremhever estetiske fag for å ta i bruk arbeidsformer og uttrykk som legger til rette for tverrfaglighet i grunnskolen (Kunnskapsdepartementet, 2019, s. 10). Spesielt retter strategiplanen søkelyset mot musikk som et viktig fag i ulike tverrfaglige sammenhenger (Kunnskapsdepartementet, 2019, s. 21). Dette kapitlet undersøker et tverrfaglig forskningsprosjekt med fagene musikk og kroppsøving gjennomført med studenter i grunnskolelærerutdanningen. Prosjektet har jeg kalt Krømus og studien hviler på en fenomenologisk kunnskapstradisjon der opplevelse er sentralt i dialog med forskerens utgangspunkt. Gjennomføringen omfattet et utforskende undervisningsopplegg som resulterte i en performance. Forskningsanalysen er basert på videoopptak av performance og intervjuer av deltakerne i etterkant, der de forteller om sine erfaringer og opplevelser ved deltakelse.

Tittelen «Bærekraft - lærekraft» henviser til ett av tre tverrfaglige temaer i LK20: «bærekraftig utvikling» (Utdanningsdirektoratet, 2017). Om bærekraftig utvikling står det i LK2O overordnet del: «Bærekraftig utvikling som tverrfaglig tema i skolen skal legge til rette for at elevene kan forstå grunnleggende dilemmaer og utviklingstrekk i samfunnet, og hvordan de kan håndteres» (Utdanningsdirektoratet, 2017, s. 13). Et av FNs bærekraftsmål er god utdanning: « $\AA$ sikre inkluderende, rettferdig og god utdanning og fremme muligheter for livslang læring for alle» (FN-sambandet, 2020). Dette kapitlet henviser til dette bærekraftsmålet og omhandler undersøkelser av bærekraft i kombinasjon med lærekraftig undervisning gjennom skapende læringsprosesser - og derav tittelen «Bærekraft - lærekraft». Med støtte i estetisk læringsteori, kroppslig læring og teori om skapende prosesser diskuteres hvordan tverrfaglig prosjektarbeid kan påvirke læringsprosesser i ulike fag. Prosjektet ses 
også i sammenheng med mål for verdier og prinsipper i LK20. Temaet er aktuelt for grunnskoleforskning, for tverrfaglig undervisning der musikk er et av fagene i skolen og i grunnskolelærerutdanningen, samt for forskning om kroppslig og sanselig læring i estetiske læringsprosesser.

Studien har følgende problemstilling: Hvordan legge til rette for en motiverende tverrfaglig loringsprosess med fokus på å utforske, skape og oppleve?

Jeg vil i det følgende presentere noen teoretiske perspektiver for kapitlets problematikk samt tidligere forskning. Videre introduseres metodedel med analyse, funn, diskusjon forankret i teori samt avslutning.

\section{Teoretiske perspektiver, begrepsforståelser og tidligere forskning}

\section{Teoretiske perspektiver}

Dewey $(1934 / 1958,2008)$ skriver om å gjøre en erfaring, og om hva det innebærer. Han likestiller en erfaring med noe som er fullbyrdet, noe som fremstår som en helhet, og som innebærer sin egen individualiserende kvalitet og selvtilstrekkelighet (Dewey, 2008, s. 196). En opplevelse kan forklares som en erfaring. Dewey mener at en helhetlig erfaring inneholder en kunstnerisk struktur, et estetisk preg, som gjør den intellektuelle erfaringen fullstendig, og at enhver sammenhengende erfaring beveger seg mot en avslutning, et endemål, siden den først opphører når de energiene som har vært aktive i den, har gjort arbeidet sitt. Dette kan ses som modning, og i denne fasen foregår læring. Følelser tilhører selvet, som er involvert i hendelsenes bevegelse mot et ønsket eller uønsket utfall, og det å sanse blir estetisk når en relasjon til en bestemt aktivitetsform kvalifiserer det som sanses (s. 202). Dette kan gjelde opplevelsen av å delta i en hendelse, som eksempelvis kan være et skapende undervisningsprosjekt, som Krømus. Dewey vektlegger den estetiske erfaringen sammen med betydningen av å reflektere kritisk over erfaringene for å utvikle forståelse og skape mening (Dewey, 1934/1958, 2008), og han argumenterer for estetiske læringsprosesser som åpner for dialog mellom elevenes emosjonelle, kognitive og fysiske forståelse av et lærestoff (Dewey, 1934/1958).

Estetiske læringsprosesser sammenstilles ofte med kreativitet og det å skape i samspill, samarbeid eller samhandling med andre. Sæbø sier 
at «[d]et å være kreativ betyr å være skapende», og «kreativitet krever et skapende mot som nettopp er evnen til å ta egne valg» (Sæbø, 2011, s. 35, 36). Sæther (2011, s. 80) samtykker i dette når han poengterer at en kreativ person søker muligheter, viser originalitet og er modig. Sæther mener dette betyr at man må bry seg, uttale seg, trosse konformitet, finne nye løsninger og våge å mislykkes. Med andre ord bør man ha en forståelse av at kreative skapende prosesser må utfordre deltakerne til å ta sjanser. I kunstfagene musikk og drama blir det ofte oppfordret til improvisasjon i utforskende prosesser. Improvisasjon i samspill med andre fører til et «levende» fellesskap, da det handler om å være spontan og om å kunne bidra med noe som ikke er innøvd eller bestemt på forhånd (Steinsholt \& Sommerro, 2006, s. 9). Improvisasjon er en viktig faktor i samspill, da man både må ta initiativ med egne forslag og respondere på andres innspill. I musisk kommunikasjon benyttes toner og lyder slik ord og tekst brukes i verbal kommunikasjon, og dette henger sammen med utforsking og kreative prosesser. Improvisasjon sammen med utforsking i kreativ framføring og kompositorisk prosess er viktige komponenter i undersøkelsen Krømus og i studien står studentenes opplevelse av den skapende prosessen sentralt.

Merleau-Ponty (1945/2012) diskuterer opplevelse gjennom kropp opp mot psykologi, og han mener at man må oppleve for å få en forståelse av noe. Å oppleve med kroppen betyr å sanse, kjenne, lukte, føle noe, og det er opplevelsen av de kroppslige erfaringene vi tar vare på i minnet. Fredens (2019) fremhever et holistisk syn på mennesket, der et helhetlig samspill mellom hjerne, kropp og omverdenen utvikler læring. Han poeng terer også at barns læring er viktig især, da barnets tidlige utvikling legger et fundament for livslang læring. I kunstfaglige aktiviteter jobber man ofte praktisk, kroppslig og affektivt på samme tid, og dette gjelder både i musikk, dans, teater og visuelle kunstfag. Dahl og Østern (2019) ser kroppslig læring i sammenheng med kognitiv læring og opplevelse:

Bevegelse, tenkning, affekter og følelser forstås i teori om kroppslig læring som parallelle aktiviteter. Dermed aktiveres både tanker, affekter og følelser i det et menneske tar del i kroppslige læreprosesser. Det er ofte mye lettere å lære, huske og la seg bevege av noe man har gjort selv, sett, tatt på, luktet på og kjent på. (Dahl \& Østern, 2019, s. 50) 
Krømus legger opp til en interaktiv læringsform med intensjon om både kroppslig og sanselig læring. I forskningsprosjektet undersøkes også hva som motiverer studentene til utforsking og skaping. I motivasjonsforskning skiller man mellom indre og ytre motivasjon (Skaalvik \& Skaalvik, 2015). Kort sagt beskriver ytre motivasjon de aktivitetene man utfører fordi man oppnår belønning, mens indre motivasjon styres av interesse og lyst. Engasjement ledes av en indre motivasjon, og motivasjon fremmer læring, og jo mer motivert elevene er, desto større innsats yter de (Skaalvik \& Skaalvik, 2015, s. 13). Brekke (2019) og Østern (2014) tar teatrets virkemidler i bruk for læring i skolen, Brekke gjennom performancekunst og Østern gjennom dramaturgi, og begge trekker fram tverrfaglighet i didaktisk kontekst. Dramaturgi og performance er disipliner i dramafaglig tradisjon, og Krømus-prosjektet har en performativ tilnærming der også drama er del av den tverrfaglige helheten. Det er derfor interessant å trekke inn det dramateoretiske perspektivet i denne undersøkelsen.

\section{Begrepsforståelser}

Det er nødvendig å redegjøre for noen av begrepene jeg benytter i forskningsprosessen, da det er flere forståelser i bruk. Dette gjelder spesifikt begrepene «bærekraft», «flerfaglighet» kontra «tverrfaglighet» samt begrepet «dybdelæring», som er et hovedmål i LK2O (Utdanningsdirektoratet, 2017). Det tverrfaglige temaet bærekraftig utvikling i LK2O overordnet del er utelatt i læreplanen for musikk, mens i læreplanen for kroppsøving handler bærekraftig utvikling om naturopplevelse med vekt på bærekraftig levemåte (Utdanningsdirektoratet, 2019c). Forankret i FNs bærekraftsmål om god utdanning bør bærekraftig utvikling implementeres i alle fag med gode læringsprosesser, også i musikk, for å sikre inkluderende, rettferdig og god utdanning for alle (FN-sambandet, 2020), og med den forståelsen benyttes begrepet bærekraft i dette kapitlet.

Dybdelæring er et av hovedprinsippene i LK20. Utdanningsdirektoratet (2019a) presenterer en egen artikkel om dybdelæring, der det understrekes at begrepet er noe mer enn faglig fordypning ved at man skal kunne anvende tilegnet kunnskap i nye situasjoner og utfordringer. 
Dahl og Østern har en annen tilnærming til begrepet, og de mener at dybdelæring dekker læring som er både kroppslig, relasjonell, skapende, affektiv og kognitiv - på samme tid (Dahl \& Østern, 2019, s. 53). I den sammenheng trekker de fram flerfaglig undervisning som en god didaktisk inngang til dybdelæring. Dette kan samsvare med studien i Krømus der prosessene tar utgangspunkt i de enkelte fags kunnskaps- og ferdighetsmål i en og samme skapende prosess. I musikk rettes søkelyset mot musikkens grunnelementer, som rytme, puls, dynamikk, samspill og til dels samklang. Her har prosjektet også intensjon om at studentene gjennom utforskingsprosessen skal utvikle kunnskap og forstålse av begreper, metoder og sammenhenger i fag og mellom fagområder, og i så måte samsvarer studiens undersøkelser også med Utdanningsdirektoratets definisjon av dybdelæring.

Begreper som omtaler flerfaglighet og tverrfaglighet, blir ofte brukt om hverandre. I LK20 (Utdanningsdirektoratet, 2017, 2019b, 2019c) brukes begrepet «tverrfaglig» kun ved bruk av de tre tverrfaglige temaene som skal implementeres i alle fag: bærekraftig utvikling, demokrati og medborgerskap og folkehelse og livsmestring. «Flerfaglig» brukes ikke i det hele tatt. I nasjonale retningslinjer for grunnskolelærerutdanning, derimot, brukes «tverrfaglig» hele 14 ganger. Her omtales tverrfaglige prosjekter, tverrfaglige perspektiver, tverrfaglige emner, tverrfaglig sammenheng, tverrfaglig samarbeid og tverrfaglig undervisning (Universitets- og høyskolerådet [UHR], 2018a, 2018b). Forfatterne Østern et al. (2019) forklarer flerfaglighet som like temaer som kan undervises på tvers av ulike fags læreplaner, og de mener at flerfaglighet på denne måten kan fungere som en agent for dybdelæring (Østern et al., 2019, s. 18). De skiller begrepene «flerfaglig» og «tverrfaglig», og poengterer at tverrfaglig undervisning ofte omfatter prosjektarbeid der flere fag er involvert over en definert periode (Østern et al., 2019, s. 17). Siden undersøkelsen Krømus er prosjektbasert og foregår i grunnskolelærerutdanningen, velger jeg å benytte begrepet som samsvarer med UHRs nasjonale retningslinjer for lærerutdanningen, altså tverrfaglig i motsetning til flerfaglig.

Også når det gjelder estetiske læringsprosesser, trengs en forklaring på hvordan det anvendes i kapitlet. Sæbø forklarer begrepet slik: «[E]stetikk 
er knyttet til det å erkjenne og forstå gjennom sanse- og følelseserfaringer. I kunstfaglig praksis og utdanning så innebærer det at det sanselige, det følelsesmessige og det kroppslige må integreres med det kognitive i lærings- og erkjennelsesprosessen» (sitert i Sæbø, 2011, s. 34). I Krømus benyttes både musikkfaglige og dramafaglige virkemidler, og intensjonen er at det sanselige, det følelsesmessige og det kroppslige skal integreres i det faglige, både i musikk og i kroppsøving.

\section{Tidligere forskning}

Tverrfaglige prosjekter med musikk og bevegelse i didaktisk sammenheng er for så vidt ikke noe nytt. Allerede på slutten av 180o-tallet og første del av 1900-tallet finner vi både Dalcroze-metoden, utviklet av JaquesDalcroze, som var særlig opptatt av kropp, bevegelse og rytme som grunnlag for musikkforståelse og musikkopplevelse (JaquesDalcroze, 1921/1973), og Carl Orff, som kombinerte musikk og dans i sin pedagogikk for å oppnå en større helhet mellom musikk og bevegelse (Hanken \& Johansen, 2013, s. 104). Ved litterære søk i Oria, ERIC og Idunn finner jeg lite innen musikkpedagogisk forskning som omhandler tverrfaglighet i grunnskolelærerutdanningen. Derimot er det flere forskningsprosjekter tilknyttet barnehagelærerutdanningen som i 2013 gjennomgikk en reform som førte til at store deler av utdanningens disiplinbaserte kurs ble slått sammen til tverrfaglige kunnskapsområder. Et av kunnskapsområdene er kunst, kultur og kreativitet (Forskrift om rammeplan for barnehagens innhold og oppgaver, 2017). Forskning på den nye reformen viser både gode argumenter for tverrfaglighet samt bekymring for at de ulike disiplinene svekkes. Hauge og Heggens undersøkelser (2019) rapporterer om debattanter som uttrykker flerfoldige utfordringer knyttet til tverrfaglig undervisning. Undersøkelsene viser at mye av bekymringene bunner i ulik begrepsforståelse av «tverrfaglighet», og at det er uenighet om hva begrepet innebærer. De foreslår en klargjøring ved å definere begrepene «tverrfaglighet», «flerfaglighet» og «transfaglighet»: «Tverrfaglighet har både potensial og fallgruver, og felles begreper kan bidra til å klargjøre disse» (Hauge \& Heggen, 2019). Denne diskusjonen er høyst aktuell, noe 
også egne undersøkelser i avsnittet om begrepsforståelse vedrørende flerfaglighet kontra tverrfaglighet viser til. Bath (2011) har på bakgrunn av studier ved barnehagelærerutdanning i England kommet fram til at tverrfaglige tilnærminger til teamarbeid kan forårsake uheldige dilemmaer med tanke på egen profesjonalitet, disiplintradisjoner og kulturelle synspunkter på teamarbeid. Han konkluderer med at for å styrke tverrfaglighet i utdanningen bør fagpersoner fra ulike disipliner modellere flerfaglig profesjonalitet, både på det pedagogiske og det organisatoriske planet, og at studenter tidlig i utdanningsløpet må opparbeide seg erfaring med tverrfaglig læring.

Av nyere tverrfaglig forskning i grunnskolelærerutdanningen i Norge vil jeg nevne «Sounding Shakespeare» (Pande-Rolfsen \& Heide, 2019), et forskningsprosjekt med fagene musikk og engelsk. Her fremstår musikk som en ledende agent for tekstlig forstålse: «In the Sounding Shakespeare project, our findings show that music becomes an important guiding agent for experiencing text in a meaningful way» (Pande-Rolfsen \& Heide, 2019, s. 101). Krømus bygger i noen grad litt på de samme skapende prinsippene, der utforsking og opplevelse for læring står i sentrum. Ved å utvide søket etter tverrfaglighet i høyere utdanning finner jeg et forskningsprosjekt i USA som omhandler det å bygge broer mellom fagdisipliner ved lærerutdanningen (Hohensee \& Lewis, 2019). Dette foregår på lærernivå ved å studere en spesiell form for kollegatrening («peer coaching») mellom lærerutdannere i fagene English language arts og mathematics education. Studien viser at ved å utføre tverrfaglig samarbeid i form av "peer coaching» åpnes dialog mellom fagene og deling av kunnskap om fagdisiplinære undervisningsmetoder.

En annen internasjonal studie undersøker vitenskapelig litteratur fra fire databaser med mål om å utvikle tverrfaglig tenkning i undervisning, noe Spelt et al. (2009) her definerer som evnen til å integrere kunnskap om to eller flere fagområder for å oppnå kognitiv læring som ville ha vært umulig gjennom bare ett av fagene. Studien viser at blant annet nysgjerrighet, læringsmiljø, teamundervisning og riktig balanse mellom kunnskapsutvikling og ferdighetstrening er viktige faktorer for utvikling av tverrfaglig tenkning. Når det gjelder den kunnskapen de tidligere studiene gir om tverrfaglig arbeid, bidrar Krømus med nye perspektiver 
på tvers av faglig innhold ved at deltakerne tilegner seg kunnskap om begrepsforståelser i de spesifikke fagene og utforsker disiplinære læringsmetoder på tvers av fag. Dette gjelder både i dialog og i kommunikasjon, $\mathrm{i}$ formidling av informasjon både kroppslig og verbalt og for hvordan man bruker undervisningsrommet.

Jeg vil i det følgende gi en nærmere beskrivelse av hvordan Krømusprosjektet ble gjennomført, og av hvordan studien er designet. Jeg ser også behovet for å problematisere og avklare etiske sider ved prosjektet.

\section{Metode}

I metodedelen vil jeg redegjøre for forskningsdesign, gjennomføring og organisering av Krømus-prosjektet. Her beskrives metodiske tilnærminger som inkluderer utvalg og datagenerering, etiske overveielser og analyse.

\section{Gjennomføring og organisering}

I forbindelse med fagfornyelsens intensjoner om mer tverrfaglig samarbeid i grunnskolen valgte jeg å designe, gjennomføre og undersøke et utforskende undervisningsopplegg ved en lærerutdanningsinstitusjon som utdanner framtidens grunnskolelærere. Et samarbeidsteam bestående av to faglærere i musikk samt en faglærer i kroppsøving deltok i planlegging og organisering. Deltakerne bestod av atten musikkstudenter og ni kroppsøvingsstudenter, og den utforskende aktiviteten foregikk i studentenes undervisningstid. Rammefaktorene vi hadde til rådighet, var en stor gymsal utstyrt med ribbevegger, gymmatter og andre myke, større og mindre treningselementer. Her fantes også basketballer, en stol, feiekoster med lange kosteskafter i tre, noen svarte tøystykker som ble benyttet til kostymekapper, og hvite masker. Hele undervisningsopplegget foregikk med et tidsforløp på fire undervisningstimer. Etter performance deltok to personer fra hver gruppe, tre studenter fra kroppsøvingsfaget og tre fra musikkfaget $i$ et fokusgruppeintervju. Jeg var selv en av faglærerne i undervisningen, og jeg veiledet den gruppa som utforsket stemme og bevegelse. 
Studentene ble oppfordret til å forberede seg ved å se gjennom noen videoer med blant annet stompaktiviteter. Stomp som sjanger ble med annet valgt for å kunne inspirere og motivere en deltakergruppe med ulik musikkompetanse. I stomp behøver man ikke å kunne beherske et musikkinstrument for å delta i samspillet, da det her spilles på forskjellige materialer og gjenstander, noe som vi tenkte skulle appellere til kroppsøvingsstudentene så vel som til musikkstudentene. Vi ba også studentene gjøre seg kjent med «haka dance» fra New Zealand. Dansen er både rytmisk, vokalt og fysisk eksponerende, og vi mente at denne inspirasjonen, som inneholder elementer fra både kroppsøvingsfaget og musikkfaget, kunne passe godt for vår målgruppe.

Studentgruppene fra de to fagene hadde ikke hatt liknende samarbeid tidligere, og vi introduserte derfor en lengre felles oppvarming på 45 minutter, der alle deltakerne samt lærere deltok. Målet var å bli varm i kropp og stemme og å forberede studentene på samspill, å få en felles forståelse av rytmisk aktivitet og rytmiske mønstre og å styrke tryggheten i gruppa for å tørre å utforske og skape sammen. Studentene ble deretter tildelt en åpen oppgave, og intensjonen var å legge til rette for utforskende, skapende prosesser uten rammer som kunne begrense den kreative utfoldelsen.

Dunk-dunk - svisj-svisj-svisj-svisj - aaaa - oooooo - iiiiiiiiiii ... Rytmer spilles med basketballer, med koster, med stemmer og kropp. Noen ganger i plenum og noen ganger solistisk. Det utøves rytmikk, dynamikk, akrobatikk og utforskes i kroppslige uttrykk, bevegelser, formasjoner og samspill. Utøverne spiller roller, er fokusert, og det skapes en spenning i rommet. (Stemningsrapport fra gjennomføring av Krømus)

Jeg befinner meg i en gymsal på en lærerutdanningsinstitusjon, og det er prosjektet Krømus som er i aktivitet. Utøverne er musikk- og kroppsøvingsstudenter som skal bli lærere i grunnskolen. Krømus ble gjennomført høsten 2018 i studentenes undervisningstid, og gjennomføringen varte i fire undervisningstimer. Opplegget bygde på kunnskaps- og ferdighetsmål fra begge fagenes emneplaner, og faglærere fra begge fagfelt deltok i både planlegging og gjennomføring.

Tabell 1 nedenfor viser organiseringen av prosjektet Krømus. 
Tabell 1

\begin{tabular}{|c|c|c|c|}
\hline Tidsforløp & Gruppe 1 & Gruppe 2 & Gruppe 3 \\
\hline $\begin{array}{l}\text { Forarbeid: } \\
\text { Info lagt ut en uke } \\
\text { før workshop }\end{array}$ & $\begin{array}{l}\text { Se video av stomp } \\
\text { performance og New } \\
\text { Zealand haka dance }\end{array}$ & $\begin{array}{l}\text { Se video av stomp } \\
\text { performance og New } \\
\text { Zealand haka dance }\end{array}$ & $\begin{array}{l}\text { Se video av stomp } \\
\text { performance og New } \\
\text { Zealand haka dance }\end{array}$ \\
\hline $\begin{array}{l}\text { Felles oppvarming: } \\
45 \mathrm{~min}\end{array}$ & $\begin{array}{l}\text { Rytmiske og fysiske } \\
\text { leker og øvelser }\end{array}$ & $\begin{array}{l}\text { Rytmiske og fysiske } \\
\text { leker og øvelser }\end{array}$ & $\begin{array}{l}\text { Rytmiske og fysiske leker } \\
\text { og øvelser }\end{array}$ \\
\hline $\begin{array}{l}1 \text { time og } 30 \\
\text { minutter }\end{array}$ & $\begin{array}{l}\text { Rytmisk komposisjon } \\
\text { med basketball } \\
\text { Lærer igangsetter } \\
\text { den utforskende } \\
\text { prosessen og veileder } \\
\text { ved behov }\end{array}$ & $\begin{array}{l}\text { Rytmisk komposisjon } \\
\text { med koster } \\
\text { Lærer igangsetter } \\
\text { den utforskende } \\
\text { prosessen og veileder } \\
\text { ved behov }\end{array}$ & $\begin{array}{l}\text { Rytmisk komposisjon } \\
\text { med stemme, bevegelse } \\
\text { og kropps-perkusjon } \\
\text { Lærer igangsetter den } \\
\text { utforskende prosessen } \\
\text { og veileder ved behov }\end{array}$ \\
\hline $30 \mathrm{~min}$ & $\begin{array}{l}\text { Forberede avslutning } \\
\text { og felles performance }\end{array}$ & $\begin{array}{l}\text { Forberede avslutning } \\
\text { og felles performance }\end{array}$ & $\begin{array}{l}\text { Forberede avslutning og } \\
\text { felles performance }\end{array}$ \\
\hline $15 \mathrm{~min}$ & $\begin{array}{l}\text { Filming av } \\
\text { performance }\end{array}$ & $\begin{array}{l}\text { Filming av } \\
\text { performance }\end{array}$ & Filming av performance \\
\hline $5 \mathrm{~min}$ & $\begin{array}{l}\text { Kort evaluering i } \\
\text { plenum }\end{array}$ & $\begin{array}{l}\text { Kort evaluering i } \\
\text { plenum }\end{array}$ & Kort evaluering i plenum \\
\hline $10 \mathrm{~min}$ & $\begin{array}{l}\text { To personer } \\
\text { deltar i filmet } \\
\text { fokusgruppeintervju }\end{array}$ & $\begin{array}{l}\text { To personer } \\
\text { deltar i filmet } \\
\text { fokusgruppeintervju }\end{array}$ & $\begin{array}{l}\text { To personer } \\
\text { deltar i filmet } \\
\text { fokusgruppeintervju }\end{array}$ \\
\hline
\end{tabular}

\section{Forklaring til Tabell 1}

I forkant hadde studentene blitt oppfordret til å forberede seg via «flipped classroom»-metoden (Carbaugh \& Doubet, 2016), som her innebar å se videoklipp fra ulike stompaktiviteter. Videoene var både fra profesjonelle regisatte forestillinger og fra mer improvisasjonsbaserte settinger i ulike dagligdagse miljøer som viser rytmiske komposisjoner der man spiller på gjenstander som ikke først og fremst er laget for å spille musikk på. Dette går fram av øverste linje i modellen under «forarbeid». Vi planla også at studentene skulle forberede seg på en mer kroppslig sjanger, og valget falt på New Zealand haka dance. Haka er opprinnelig maorifolkets krigsdans, og New Zealands landslag i rugby tar med seg denne tradisjonen når de framfører en haka før hver kamp.

Etter en 45 minutters felles oppvarming med rytmiske og fysiske leker ble studentene delt i tre grupper på tvers av fag med ni personer på hver gruppe. Studentene fikk en åpen oppgave med et konkret mål der de skulle komme fram til et produkt, en performance som skulle ha en start, et høydepunkt eller et vendepunkt og en slutt. Vi var tre lærere til stede 
som igangsatte hver vår gruppe, og som ga veiledning ved behov, og denne delen var utforskingsaktivitetens hoveddel og pågikk i en time og tretti minutter. Gruppe 1 fikk i oppdrag å lage rytmisk komposisjon med basketballer, gruppe 2 brukte koster som instrumenter, og gruppe 3 brukte stemme, bevegelse og kroppsperkusjon som instrumenter. Som veiledere oppfordret vi studentene til å utforske materialene og gjenstandene de brukte, med søkelys på klang, bevegelse, puls og rytme. Gruppene skapte en performativ musisk-fysisk scene hver for seg, noe som her innebar en etablering av et gruppemiljø og en handling med en forhåndsbestemt start og et dynamisk forløp. Her var det rom for improvisasjon i samspillet, både musisk og dramatisk. Til slutt ble de tre scenene satt sammen til en helhetlig performance, som etter tretti minutters forberedelse ble filmet med varighet ti minutter. Performance forstås her som en forestilling der alle studentene deltok. Etter praktisk gjennomføring ble alle samlet til en kort evaluering i plenum, og deretter deltok seks av studentene i et gruppeintervju. Intervjuet ble filmet.

\section{Utvalg og datagenerering}

Det empiriske materialet er i form av videoopptak av performance der alle studentene deltok, og et fokusintervju med en mindre gruppe av de deltakende studentene. Intervjuet foregikk etter undervisningstid, og det var frivillig deltakelse. Jeg valgte et fokusgruppeintervju i motsetning til individuelle intervjuer, da førstnevnte kan legge til rette for interaksjon og diskusjon mellom deltakerne (Kvale \& Brinkman, 1977/2009). Sammensetningen av intervjugruppa med halvparten musikkstudenter og halvparten kroppsøvingsstudenter ble valgt for å få likt antall fra begge de representative fagfeltene. Jeg ønsket et utvalg der alle de tre gruppene var representert, for eventuelt å spore om opplevelsen hadde vært forskjellig i de utforskende undervisningsgruppene. Intervjuet ble deretter transkribert og analysert.

\section{Etiske overveielser}

For å ivareta deltakeres personvern ble alle involverte før prosjektets oppstart opplyst om at Krømus inngikk i forskning med formål om å 
utvikle nye tverrfaglige undervisningsmetoder i grunnskolelærerutdanningen. Et dilemma jeg måtte ta stilling til, var at tidsrommet for gjennomføring av Krømus ble lagt til ordinær undervisningstid, noe som ble valgt på grunn av organisering av antall studenter og rom.

I samsvar med nasjonale forskningsetiske retningslinjer (De nasjonale forskningsetiske komiteene, 2016) var det nødvendig med samtykke fra alle som deltok i performance, da denne ble filmet, og jeg valgte derfor å la deltakelse i denne sekvensen være frivillig. Gruppa som deltok i performance, klassifiserer jeg i denne studien som «utvalg 2». «Utvalg 1» besto av deltakere som, i tillegg til deltakelse i performance, bidro i fokusintervjuet etter undervisningstid. Disse studentene meldte sin interesse for deltakelse selv, og de samtykket til at intervjuet ble filmet, transkribert og analysert. De samtykket også til at sitater fra intervjuet kunne brukes i dette kapitlet, og som forsker har jeg vært i dialog med deltakerne i skriveprosessen, der de har fått mulighet til å lese gjennom de delene av kapitlet der de er sitert. Etiske retningslinjer er ivaretatt ved å følge de nasjonale forskningsetiske retningslinjene for samfunnsfag og humaniora (De nasjonale forskningsetiske komiteene, 2016) og med godkjenning fra NSD - Norsk senter for forskningsdata.

\section{Analyse}

Det er foretatt analyse av både transkribert intervju og filmet performance. I analysen benytter jeg en kvalitativ induktiv tilnærming med koding og kategorisering støttet av grounded theory» (GT) (Charmaz, 2014; Corbin \& Strauss, 2015). Studien er orientert mot motivasjon for å oppleve, utforske og skape i en performativ interaksjon med deltakende studenter, og samspillet (her underforstått også samarbeid og samhandling) i prosjektets performance blir analysert fra et tverrfaglig perspektiv. Følgende forskningsspørsmål er styrende i analysen: Hvordan motiverer prosjektet Krømus til utforsking og skaping, og hvordan opplever studentene det å jobbe tverrfaglig i prosjektet? Jeg ser også spesifikt på hvilke læringsstrategier studentene benytter, og jeg retter spesiell oppmerksomhet på musikk- og dramadelen i prosjektet, da dette er mitt kompetansefagfelt. I prosessen med GT har analysearbeidet foregått 
i flere faser. Jeg har benyttet ulike teoretiske perspektiver underveis, noe som har gitt framdrift i prosessen og har drevet analysen mot nye funn.

Jeg startet analysearbeidet med en åpen koding, som her betydde å være så konkret og nær det empiriske materialet som mulig. Corbin og Strauss oppfordrer i denne fasen forskeren til å se data fra deltakernes ståsted, og de kaller denne delen av analysen «lower-level concepts» (Corbin \& Strauss, 2015, s. 77). Koder i denne fasen var stort sett positive erfaringer. For å undersøke nærmere benyttet jeg «word-by-word»og «line-by-line»-koding (Charmaz, 2014, s. 124) på noe av materialet, som vil si å analysere ord for ord og linje for linje. Dette resulterte i en forståelse som kan bety underliggende skepsis og utrygghet hos deltakerne. Uttrykk som «det var flaut i begynnelsen» og «du frykter litt, for du vet ikke hva som skal skje» understreker dette. I videre analyse framsto tre hovedkategorier: motivasjon, opplevelse og tverrfaglighet. Disse presenteres med underkategorier i funn.

\section{Funn}

\section{Motivasjon}

I analysen er det fire hovedkategorier som gjør seg gjeldende under punktet motivasjon: performance, samspill, trygghet og praksisnærhet.

Om prosjektet som helhet sier studentene at det har vært «gøy», «lærerikt», «interessant» og «spennende å delta». Mange var spent på forhånd, da de ikke visste helt hva som møtte dem: «[M]en når du kjem til det, så er det veldig positiv overraskelse.» Det faktum at prosessen skal lede fram til et sluttresultat, motiverer studentene. Her er målet en performance i samspill med hele ensemblet, og det stiller krav til bidrag i form av en performativ sekvens fra alle gruppene. På spørsmål om de kunne nevne noe som var spesielt bra, svarer studentene: «Jeg synes det var positivt at alle skapte noe sammen til slutt. Det var artig å se på også, og framføre.» Det å skape sammen er også noe som flere kommenterer som motiverende: «Det var gøy, og vi fikk øvd oss mer på samarbeidsferdigheter.» Mange av studentene nevner at trygghetsaspektet er viktig: «Jeg ble veldig fort kjent med de jeg var på gruppe med.» En annen sterk motivasjonsfaktor som nevnes av flere studenter, er at de ser prosjektet som praksisnært, 
«noe man kan ta med inn i skolen», og de trekker raskt linjer til sin egen framtidige yrkesprofesjon. Her er det snakk om en indre motivasjon som styres av interesse og lyst (Skaalvik \& Skaalvik, 2015).

\section{Opplevelse av å skape og utforske}

Intensjonen med Krømus er at prosessene skal være utforskende og skapende. Etter felles oppvarming jobbet de tre gruppene hver for seg i ulike deler av en stor gymsal. Om prosessen sier studentene: «Synes alle gruppene var veldig oppfinnsomme. Aktivitetan var veldig varierte, og oppgaven så åpen at vi måtte diskutere og snakke i lag og finne ut av ting selv.» De syntes det var lett å komme i gang med den skapende prosessen:

Vi tok mye inspirasjon fra den oppvarmingsøvelsen vi hadde fått på forhånd.

Ordet ble bare naturlig tatt av de som hadde noe å si. Vi laga det lagvis på en måte, når vi fikk starten på gli, var det liksom naturlig å gå videre.

Her var det ubalanse i gruppene vedrørende fagkunnskap, da det var dobbelt så mange musikkstudenter som kroppsøvingsstudenter. Det kan se ut som om de med kompetanse i musikkfaget (de som hadde noe å si) tar styring og tar ansvar overfor resten av gruppa:

Når det gjaldt rytme, og en fikk i oppgave å slå på $1 \mathrm{og} 3$, men han sa han syntes det hørtes vanskelig ut, så viste vi han det liksom 1, 2, 3, 4 [teller i puls], det gikk jo bra, han klarte jo det, men vi måtte liksom dra de litt i gang.

Dette kan tyde på at det er lettere å komme i gang med prosessen om man har faglig kompetanse. Her må det understrekes at det ikke spesifikt er gjort videre undersøkelser på de deltakerne som ble «hjulpet i gang», og det finnes dermed ikke data på deres opplevelser i prosessen, om det å bli ledet inn i det skapende virket hemmende eller motiverende på egen kreativitet. Slik jeg tolker det, opplevde studentene som deltok i intervjuet, prosessen som utforskende, skapende og kreativ, og de mente at den åpne oppgaveformen førte til variasjon i aktivitetene. Imidlertid ser det ut til at veiledning, enten av faglærer eller medstudenter var nødvendig for at en av gruppene skulle komme i gang, noe som kan bety at det er greit med noen rammer (sekvensen skal ha en start, et vendepunkt og 
en slutt) og et mål med en avsluttende performance for å få fremdrift $\mathrm{i}$ arbeidet. Av videoanalysen går det fram at det meste i denne performancen var forutbestemt. Det er med andre ord lite rom for fri improvisasjon og spontane hendelser der og da. Dette kan skyldes at improvisasjon er ukjent og dermed utrygt terreng for studentene. Men når det er sagt, var spontanitet og improvisasjon sterkt til stede i den utforskende, skapende prosessen.

\section{Tverrfaglig prosjektarbeid og dybdelæring}

Så hvordan opplevde studentene det å jobbe tverrfaglig? Her er det utelukkende positive svar: «Tommel opp. Kunne gjerne tenkt meg mere tverrfaglig arbeid.» Flere ser overføringsverdi til læreryrket i grunnskolen: «Det å jobbe med akkurat slike prosjekt, det er jo det man har lyst til å ta med videre. Tror elever også kan både oppleve mestring, læring og ha det gøy samtidig gjennom denne typen aktivitet.» Flere trekker også fram at de liker å jobbe praktisk i prosjektet. Dybdelæring blir nevnt i tråd med Dahl og Østerns (2019) definisjon, der flere fag belyser samme tema: «Det blir mere tydelig for oss og elevene at fagene har en sammenheng, at det er ikke bare individuelle fag men, det er fagene i lag som bidrar til utdanning.» Noen nevner tidsaspektet som en utfordring:

Kanskje tidsmessig må de ha mere tid, for det her er jo veldig sånn fort og gæli, jeg ble personlig ikke kjempefornøyd med produktet, det var ok, men ikke mer enn ok, så hadde vi hatt bedre tid, hadde det sikkert blitt bedre.

Ønske om mer tid er et kjent dilemma i tverrfaglig undervisning, og her sier utsagnet også noe om opplevelsen. Det kan oppleves som at man ikke mestrer godt nok når produktet ikke er tilfredsstillende, men bare «ok».

Videoanalysen viser at alle gruppene utforsker rommet ved å benytte flere plan, liggende på gulvet, sittende og stående. De benytter også ribbevegg, og en gruppe bruker en stol til å stå på, noe som fremhever makt i gruppespillet. Her bruker studentene rommet dramaturgisk, og plassering i rommet understreker aktørenes status i spillet. Gruppene varierer plassering med ulike formasjoner og kroppsspråk og skaper 
komposisjoner med rytmiske motiver, noen mer intrikate enn andre ved bruk av flere underdelinger og synkoper.

Samspillet i gruppene er sterkt forankret i felles energi, noe som betyr at de lytter og sanser hverandre. Ingen bruker ord, men de lager lyder med stemmen, kroppen og de materialene de jobber med, som basketballer og koster. Det klanglige utforskes både vokalt i høyt og lavt register og i gjenstanders ulike klanger ved ulik bruk, eksempelvis ved å benytte hender mot gulvet, ved å slå kosteskafter mot hverandre, ved å slå kostebørsten mot gulvet i rytmisk mønster og ved å sprette en ball mot vegg og gulv. Det benyttes pauser som skaper spenning, og varierende volum, tempo og dynamikk driver handlingen fremover. Fremdrift forsterkes ytterligere av dramatiske virkemidler som dramatisk fiksjon, spenning og overraskelser (Sæbø, 2016). Samspillet står sentralt i både bevegelser og lyd, og studentene får en kroppslig forståelse av musikkens grunnelementer som puls, rytme, tempo, form, dynamikk og klang. Dette er læring som også kan overføres til bevissthet om klasseledelse. Det handler om kommunikasjon mellom aktører, om hvordan plassering i rom gir varierte signaler, og om dramaturgi i oppbygging og form (Østern, 2014).

\section{Oppsummering av funn}

Følgende forskningsspørsmål har vært styrende i analyseprosessen: Hvordan motiverer prosjektet Krømus til utforsking og skaping, og hvordan opplever studentene det å jobbe tverrfaglig i prosjektet?

Kort oppsummert er det fire faktorer som fremtrer som motiverende for utforsking og skaping i prosjektet Krømus:

1) Å ha et konkret mål å jobbe mot, her en performance.

2) Å skape sammen med andre.

3) At prosjektet er praksisnært.

4) Trygghet.

Av faktorer der det kan diskuteres hvorvidt de fører til begrensninger i den kreative prosessen, nevner studentene at det var litt «flaut i starten», 
og «utrygt» da man ikke visste hva som skulle skje, og at de som hadde mest kompetanse i musikk, tok styring i prosessen. Opplevelsen av å jobbe tverrfaglig i prosjektet fremstår stort sett som positiv. Deltakerne trekker frem godt samarbeid, mestring og læring ved å ha det gøy, og at de ved å jobbe tverrfaglig ser at fagene har en sammenheng, men de uttrykker også en viss misnøye med at de har for lite tid til å skape et resultat de er godt fornøyd med, og at dette kan påvirke opplevelsen.

Diskusjonsdelen starter med forklaring av en figur som sammenfatter funn fra analysen, og modellen drøftes og diskuteres ut fra kapitlets problemstilling: Hvordan legge til rette for en motiverende tverrfaglig loeringsprosess med fokus på å utforske, skape og oppleve?

\section{Diskusjon}

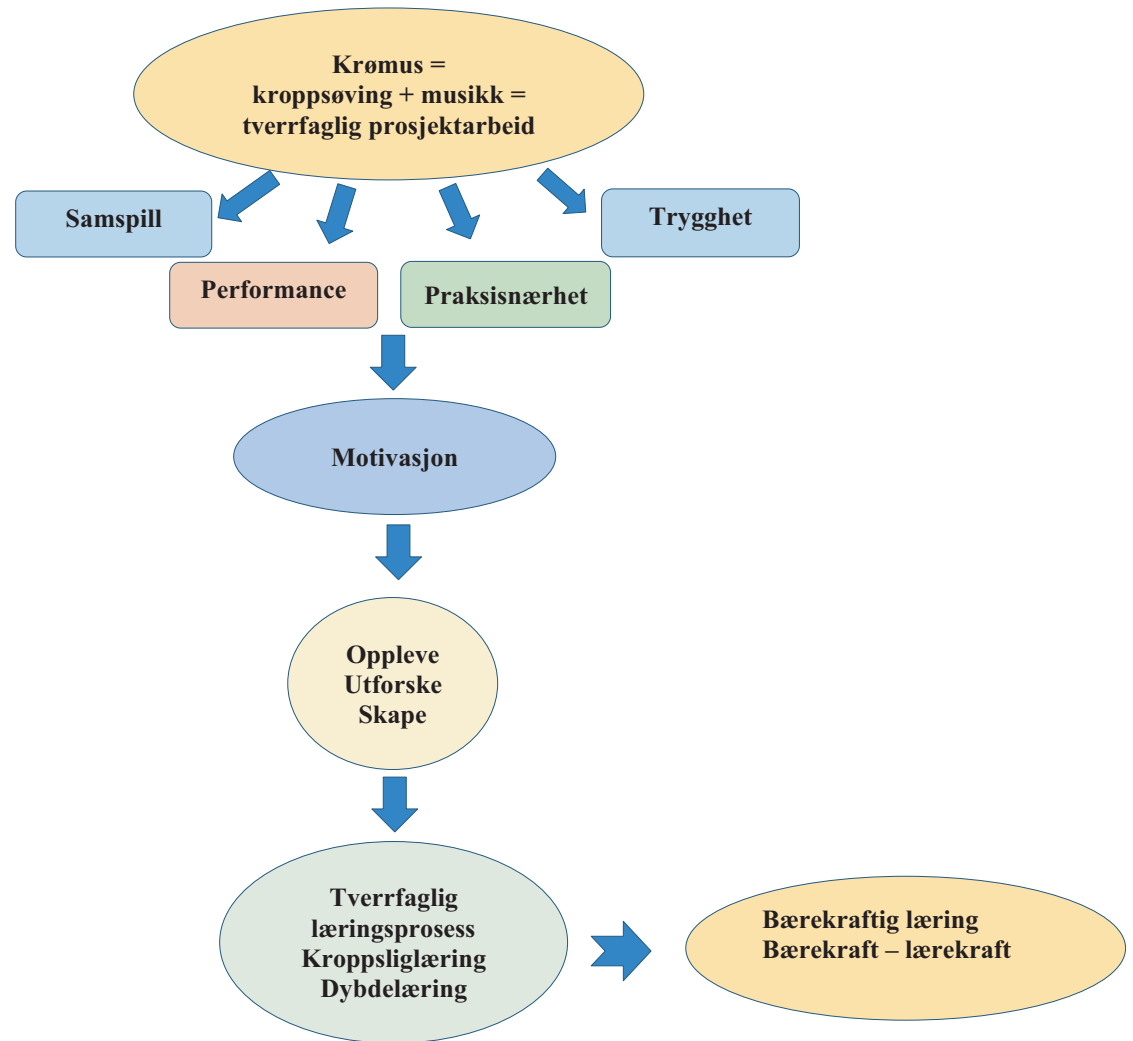

Figur 1 Tverrfaglig læringsprosess 


\section{Forklaring av figur 1}

Jeg vil benytte figur 1, «tverrfaglig læringsprosess», som utgangspunkt for diskusjonsdelen, der forklaring av selve modellen fungerer som ramme.

Funn fra analysen viser fire kategorier som motiverer for utforskende tverrfaglig prosess i prosjektet Krømus: performance, samspill, trygghet og praksisnærhet. Performance motiverer deltakerne fordi det er et mål, en ferdigstillelse av prosjektet, en helhetlig erfaring. Ifølge Dewey har man en erfaring når det materialet man erfarer, når frem til fullbyrdelse.

Et stykke arbeid er fullført på en tilfredsstillende måte; et problem når sin løsning; et spill spilles til ende; en situasjon, [...], avrundes på en slik måte at avslutningen blir en fullbyrdelse og ikke et opphør. En slik erfaring er en helhet og i seg bærer den sin egen individualiserende kvalitet og selvtilstrekkelighet.

(Dewey, 2008, s. 196)

Den estetiske kvaliteten som kompletterer en erfaring og gjør den fullstendig og hel, omtaler Dewey (2008, s. 201) som emosjonell. Mot endemålet, her forstått som performance, skjer en modning, en prosess, som jeg vil tolke som læring. Modningen skjer ved at følelser aktiviseres gjennom opplevelse ved å utforske og skape. En opplevelse i form av et resultat som ikke oppleves bra eller ferdig (i Krømus uttrykt med «bare ok»), kan dermed føre til en opplevelse av noe som ikke er fullbyrdet. Med andre ord kan man forstå det slik at også kvaliteten på selve produktet, ikke bare prosessen, er viktig for opplevelsen.

I estetiske læringsprosesser som Krømus skjer en «åpen» mestring i fellesskapet, og ifølge Sæbø (2016) er det viktig at hver deltaker føler at de lykkes og blir inspirert og motivert til fortsatt innsats i egen læringsprosess. To viktige aspekter gjør seg dermed gjeldende: Det å ha nok tid, slik at man får øvd tilstrekkelig på alle de faktorene som inngår i produksjonen, samt kompetanse for å vite hvordan man skal oppnå dette. Både Brekke (2019) og Sæbø (2011) påpeker viktigheten av læreres kompetanse i kunstfag ved undervisning i estetiske læringsprosesser.

En modning foregår også gjennom samspillet i gruppa. Samspill og det å skape i fellesskap er noe studentene nevner som motiverende. Gjennom utforskende improviserte sekvenser i prosessen oppstår et «levende» fellesskap (Steinsholt \& Sommerro, 2006). Studentene sier i 
intervjuet at de «samarbeider godt», og de bruker og deler egen kompetanse fra sine fag, her musikk og kroppsøving. Ved å dele kunnskap i praktiske prosesser skapes et inkluderende miljø, og forskning nevner kollegalæring som et viktig verktøy (Brekke 2019; Hohensee \& Lewis, 2019). «Gjennom kollegalæring kan en få kunnskap om nye metoder og verktøy til egen undervisning, og en får anledning til å delta i nyskapende prosesser» (Brekke, 2019, s. 30). Det er nettopp dette som skjer i Krømus, der musikkstudentene lærer kroppsøvingsstudentene om rytmeforståelse. I kollegalæring kan man også se mulighet for oppklaring og felles forståelse av begrepet tverrfaglighet ved at kollegaer fra ulike fagfelt kommer i nært samarbeid og får kjennskap til flere fags tradisjoner og verdier. Nettopp denne ulike forståelsen av begrepet «tverrfaglighet» forvirrer og er et dilemma i tverrfaglig samarbeid (Bath, 2011; Hauge \& Heggen, 2019).

Å være skapende er å være kreativ, og det krever mot (Sæbø, 2011; Sæther, 2011). Funn fra analysen viser at trygghet i gruppa motiverer deltakerne i Krømus til å skape og utforske sammen. Det å tørre å ta sjanser i en utforskende aktivitet henger sammen med å være modig, og ved å utfordre seg selv i kunstfaglige øvelser i trygge rammer øker man både sosiale og kunstfaglige kompetanser (Sæbø, 2016). Det er en åpen mestring som skjer i fellesskapet fordi flere deltar og at nettopp dette kan være ekstra inspirerende og motiverende, og det å føle seg trygg i et fellesskap åpner for kreativ utforsking (Sæbø, 2016). Noen av intervjudeltakerne poengterte at det var «flaut» og «utrygt» i begynnelsen av den skapende prosessen. Tross 45 minutter med oppvarming kan dette vitne om at studentene ikke var trygge nok i gruppa til å bidra maksimalt i det skapende fellesskapet. Bath (2011) konkluderer i sin undersøkelse med at studentene må få erfaring med tverrfaglig læring tidlig i studieløpet. Hadde studentene vært kjent med liknende prosesser, ville det kanskje ikke ha vært «flaut» og «utrygt» i starten av gruppearbeidet, og kanskje det skapende arbeidet hadde kommet tidligere i gang. Et trygt læringsmiljø ses også i samsvar med faglig og pedagogisk trygghet, som sammen med blant annet nysgjerrighet, åpenhet og respekt ifølge internasjonal forskning er gode faktorer for tverrfaglig tenkning (Spelt et al., 2009, s. 375), noe jeg forstår som tverrfaglig kunnskap. 
Å benytte dramaturgi i didaktisk kontekst er en metode for å skape trygge rammer. «Å tenke som en dramaturg i undervisning betyr å planlegge i helheter som begynnelse - prosess - sluttprodukt - evaluering» (Østern, 2014, s. 23). I Krømus fikk studentene dramaturgiske rammer i oppgaven ved å forholde seg til en start, et vendepunkt og en slutt, noe som så ut til å resultere i engasjement og fremdrift i gruppeprosessen. Evaluering fremheves som en viktig faktor i estetiske læringsprosesser (Dewey, 2008; Sæbø, 2016; Østern, 2014). I Krømus ble det gjennomført en kort evaluering etter fremføring av performance. Som forsker ser jeg at denne skulle ha vært mye lengre, dypere og mer omfattende. I skapende og utforskende arbeid er kreativiteten og fantasien innom mange ideer og spørsmål som bør bearbeides i en evaluerende samtale. I en tverrfaglig prosess belyses tematikker fra flere fagområder, ofte på samme tid, og dialog og erfaringsdeling i etterkant er derfor viktig for læring. I denne konteksten burde det ha vært satt av tid til refleksjon ved å se på egen opplevelse og erfaring i sammenheng med læringsmål og læringsstrategier i grunnskolelærerutdanningen. Det kom tydelig frem at studentene motiveres ved å se koblinger til yrkesprofesjon, til den praksisen de vil møte som fremtidige lærere. Kategorien «praksisnærhet» knyttes i figur 1 sammen med de tre andre motivasjonskategoriene, og dette viser at når de fire faktorene er til stede, er det motivasjon for å utforske, skape og oppleve. Som læringsformer er disse egenskapene fremhevet i LK2O og kan ses i sammenheng med begrepene skaperglede, engasjement og utforskertrang, som løftes fram i verdier og prinsipper for opplæring (Utdanningsdirektoratet, 2017).

I Krømus undersøkes det å utforske, skape og oppleve i en tverrfaglig læringsprosess. Noe av de samme prinsipper for læring finner vi i artikkelen «Sounding Shakespeare» (Pande-Rolfsen \& Heide, 2019). Her presenteres og undersøkes et tverrfaglig forskningsprosjekt med fagene musikk og engelsk, der læring gjennom estetisk tilnærming til språk i en musikalsk kontekst fører til en musikalsk måte å oppleve språk på. Musikk fungerer her som en «leading agent» i møte med Shakespeares tekster. Fredens (2019) mener at konteksten ofte er viktigere enn vi egentlig er klar over. Den påvirker og styrer både tanker, følelser og handlinger, og læring kan fremmes ved at man flytter ut av en situasjon og inn i en 
annen (Fredens, 2019, s. 153). Den andre situasjonen kan her være en ny tverrfaglig kontekst, og læring skjer ved en ny tilnærming. I Krømus gjelder dette i både musikk- og kroppsøvingsfaget. Her implementeres fagene sammen i en interaktiv, performativ læringsprosess der man utforsker musikkens grunnelementer kroppslig og sanselig, og læring oppstår gjennom estetisk erfaring i et kreativt fellesskap (Dewey, 2008; Merleau-Ponty, 1945/2012). I prosessens samspill brukes sansene til å lytte og oppleve, og gjennom praktisk skapende aktiviteter og rytmisk utfoldelse i performative sekvenser utøves sanselig og kroppslig læring, noe som her kan forstås som dybdelæring (Dahl \& Østern, 2019; Utdanningsdirektoratet, 2017).

\section{Avslutning}

I kapitlet «Bærekraft - lærekraft» har jeg analysert forskningsmaterialet av prosjektet Krømus, og jeg har funnet komponenter som er viktige for å legge til rette for en motiverende tverrfaglig læringsprosess med søkelys på å utforske, skape og oppleve. I læringsprosessen jobber grunnskolelærerstudenter med estetiske læringsstrategier på både kroppslig og sanselig plan.

I diskusjonen er funn som er gjort i analysen, drøftet med teori, og det er argumentert for hvordan en tverrfaglig læringsprosess kan motivere til å utforske, skape og oppleve.

Gjennom samspill jobbes det med inkluderende prosesser i et skapende og utforskende fellesskap, der verdier kan knyttes til FNs bærekraftsmål nummer 4, som er bærekraftig utdanning (FN-sambandet, 2020). Slik vil jeg konkludere med at tverrfaglige læringsprosesser kan være bærekraftig læring. Ifølge studentene praktiseres i liten grad tverrfaglig undervisning i lærerutdanningen i dag. Dette samsvarer ikke med nasjonale retningslinjer for grunnskolelærerutdanningen (Universitets- og høgskolerådet, 2018a, 2018b), der ordet «tverrfaglig» brukes hele 14 ganger, blant annet om tverrfaglige prosjekter, emner, sammenhenger og samarbeid. Et mål fremover må være å skape rammer i studiemodellene for å oppnå rom for tverrfaglige estetiske læringsprosesser i form av bærekraftig lærekraft for dybdelæring. 


\section{Referanser}

Bath, C. (2011). Participatory concepts of multidisciplinary/professional working on an Early Childhood Studies degree course in the UK. Early Years, 31(2), 181-192. https://doi.org/10.1080/09575146.2011.561484

Brekke, A.-H. (2019). Idèbok: På tvers med performancekunst. Norsk kulturskoleråd.

Carbaugh, E. M. \& Doubet, K. J. (2016). The differentiated flipped classroom: A practical guide to digital learning. Corwin.

Charmaz, K. (2014). Constructing grounded theory. SAGE Publications.

Corbin, J. \& Strauss, A. (2015). Basics for qualitative research (4. utg.). SAGE Publications.

Dahl, T. \& Østern, T. P. (2019). Dybde//læring med overflate og dybde. I T. P. Østern, T. Dahl, A. Strømme, J. A. Petersen, A.-L. Østern \& S. Selander (Red.), Dybdelcering - en flerfaglig, relasjonell og skapende tilnoerming (s. 39-56). Universitetsforlaget.

De nasjonale forskningsetiske komiteene. (2016). Forskningsetiske retningslinjer for samfunnsvitenskap, humaniora, juss og teologi. https://www.forskningsetikk.no/ ressurser/publikasjoner/retningslinjer-nesh/

Dewey, J. (1958). Art as experience. Capricorn Books. (Opprinnelig utgitt 1934)

Dewey, J. (2008). «Å gjøre en erfaring»: fra art as experience. (A. Øye, Overs). I K. Bale \& Bø-Rygg (Red.), Estetisk teori: en antologi (s. 196-214). Universitetsforlaget.

FN-sambandet. (2020). FNs bærekraftsmål. https://www.fn.no/Om-FN/FNsbaerekraftsmaal

Forskrift om rammeplan for barnehagens innhold og oppgaver. (2017). Forskrift om rammeplan for barnehagens innhold og oppgaver (FOR-2017-04-24-487). Lovdata. https://lovdata.no/dokument/SF/forskrift/2017-04-24-487/

Forskrift om rammeplan for grunnskolelærerutdanning for trinn 1-7. (2016). Forskrift om rammeplan for grunnskolelorerutdanning for trinn 1-7 (FOR-2016o6-07-860). Lovdata. https://lovdata.no/dokument/SF/forskrift/2016-06-07-86o

Forskrift om rammeplan for grunnlærerutdanning for trinn 5-10. (2016). Forskrift om rammeplan for grunnskoleloererutdanning for trinn 5-10. Lovdata. https:// lovdata.no/dokument/LTI/forskrift/2016-06-07-861

Fredens, K. (2019). Læring: et samspill mellom hjerne, kropp og omverden. (A. Solli, Overs.) Cappelen Damm Akademisk.

Hanken, I. M. \& Johansen, G. (2013). Musikkundervisningens didaktikk. Cappelen Damm Akademisk.

Hauge, K. H. \& Heggen, M. P. (2019). Tverrfaglighet i norsk barnehagelærerutdanning - et forslag til begrepsavklaring. Nordic Studies in Education, 39(4). https://www.idunn.no/np/2019/o4/tverrfaglighet_i_norsk_ barnehagelaererutdanning 
Hohensee, C. \& Lewis, W. E. (2019). Building bridges: A cross-disciplinary peercoaching self-study. Studying Teacher Education, 15(2), 98-117. https://doi.org/10.1 o8o/17425964.2018.1555525

Jaques-Dalcroze, É. (1973). Rhythm music and education. The Dalcroze Society. (Opprinnelig utgitt 1921)

Karlsen, G. (2006). Stil overfor det som ennå ikke er. I K. Steinsholt \& H. Sommerro (Red.), Improvisasjon. Kunsten å sette seg selv på spill (s. 239-261). Damm.

Kunnskapsdepartementet. (2019). Skaperglede engasjement og utforskertrang (Rapport). https://www.regjeringen.no/no/dokumenter/skaperglede-engasjement ogutforskertrang/id2665820/

Kvale, S. \& Brinkmann, S. (2009). Det kvalitative forskningsintervju (T. M. Anderssen \& J. Rygge, Overs.). Gyldendal Akademisk. (Opprinnelig utgitt 1977)

Merleau-Ponty, M. (2012). Phenomenology of perception. Routledge. (Opprinnelig utgitt 1945)

Pande-Rolfsen, M. S. \& Heide, A.-L. (2019). Sounding Shakespeare: An interdisciplinary educational design project in English and music. Early Modern Culture Online, 7(1), 87-104. https://doi.org/10.15845/emco.v7i1.2830

Skaalvik, E. M. \& Skaalvik, S. (2015). Motivasjon for loering - teori og praksis. Universitetsforlaget.

Spelt, E. J. H., Biemans, H. J. A., Tobi, H., Luning, P. A. \& Mulder, M. (2009). Teaching and learning in interdisciplinary higher education: A systematic review. Educational Psychology Review, 21, 365-378. https://doi.org/10.1007/s10648-009-9113-Z

Stavik-Karlsen, G. (2013). Provokasjon for å koble elevene på. I A.-L. Østern, G. Stavik-Karlsen \& E. Angelo (Red.), Kunstpedagogikk og kunnskapsutvikling (s. 234-260). Universitetsforlaget.

Steinsholt, K. \& Sommerro, H. (2006). Improvisasjon. Kunsten å sette seg selv på spill. Damm.

Sæbø, A. B. (2011). Kunstfagenes plass i barnehagen. I K. Bakke, C. Jenssen \& A. B. Sæbø (Red.), Kunstfag, kultur og kreativitet: kunstfaglig arbeid $i$ barnehagen (s. 15-43). Fagbokforlaget.

Sæbø, A. B. (2016). Drama som loeringsform. Universitetsforlaget.

Sæther, M. (2014). Kreativ ute med musikk. Estetiske prosesser i musikk innen fagområdet kunst, kultur og kreativitet. I M. Sæther \& T. L. Hagen (Red.), Kreativ ute (s. 73-96). Fagbokforlaget.

Sæther, M. (2011). Musikk og estetiske prosesser i barnehagen, I K. Bakke, C. Jenssen \& A. B. Sæbø (Red.), Kunstfag, kultur og kreativitet: Kunstfaglig arbeid $i$ barnehagen (s. 73-97). Fagbokforlaget.

Sætre, J. H. (2006). Barns musikkskaping - improvisasjon og komposisjon i grunnskolen. I K. Steinsholt \& H. Sommerro (Red.), Improvisasjon. Kunsten å sette seg selv på spill (s. 133-153). Damm. 
Universitets- og høgskolerådet. (2018a). Nasjonale retningslinjer for grunnskoleloererutdanning trinn 1-7. https://www.uhr.no/_f/p1/ibda59a76750c-43f2-b95a-a7690820ccf4/revidert-171018-nasjonale-retningslinjer-forgrunnskolelarerutdanning-trinn-1-7_fin.pdf

Universitets- og høgskolerådet. (2018b). Nasjonale retningslinjer for grunnskoleloererutdanning trinn 5-10. https://www.uhr.no/_f/p1/iffeaf9b96786-45f5-8f31-e384b45195e4/revidert-171018-nasjonale-retningslinjer-forgrunnskoleutdanning-trinn-5-10_fin.pdf

Utdanningsdirektoratet. (2017). Overordnet del - verdier og prinsipper for grunnopploringen. https://www.regjeringen.no/ contentassets/37f2f7e1850046aoa3f676fd45851384/overordnet-del---verdier-ogprinsipper-for-grunnopplaringen.pdf

Utdanningsdirektoratet. (2019a). Dybdeloering. https://www.udir.no/laring-ogtrivsel/dybdelaring/

Utdanningsdirektoratet. (2019b). Lœreplan i musikk (MUSo1-02). https://www.udir. no/lk2o/muso1-02

Utdanningsdirektoratet. (2019c). Loreplan i kroppsøving (KRO01-05). https:// sokeresultat.udir.no/?query=KROo1-05

Østern, A.-L. (2014). Dramaturgi i didaktisk kontekst. Fagbokforlaget.

Østern, T. P, Dahl, T. Strømme, A. Petersen, J. A. \& Selander, S. (2019). Et intraagerende prosjekt om dybde//læring. I T. P. Østern, T. Dahl, A. Strømme, J. Petersen, A.-L. Østern \& S. Selander (Red.), Dybdeloring - en flerfaglig, relasjonell og skapende tilnoerming (s. 15-27). Universitetsforlaget. 



\title{
Evaluering av konsertformidling i høyere utdanning
}

\author{
Roy A. Waade \& Anders Dalane \\ Nord universitet
}

\begin{abstract}
This chapter is based on an examination of the subject Dissemination and Concert Production, which is part of the bachelor program for music teacher education at Nord University, Levanger. The authors highlight challenges and opportunities that this subject gives for teachers and students, with particular focus on how to assess a subject that is about creating and presenting concert productions. The Danish model "ønskekvistmodellen" (ØM) is employed as an analysis and evaluation tool to examine the students work with improving the quality of creating, performing and evaluating various concert productions in the years 2017-2019. Data material for the chapter consists of surveys, group interviews and video observation, as well as written reports from the student's participation at music and art festival (Vrimmel-festivalen) in the northern part of Mid-Norway.
\end{abstract}

Keywords: music education students, concert productions, assessments, quality, ønskekvistmodellen, action research

Kvalitetsvurderinger innenfor kunstformidling og konsertproduksjon er et utfordrende tema. Blant annet bringer det med seg spørsmål om hvem som skal vurdere kvalitet i forhold til hva, og på hvilke måter vurderingene best kan foregå. Dette kapitlet handler om vurderinger i musikklærerutdanningsfaget «formidling og konsertproduksjon», og det er her studentenes og lærerutdannernes kvalitetsbedømminger som undersøkes ved hjelp av evalueringsmetoden «ønskekvistmodellen»

Sitering av dette kapitlet: Waade, R. A. \& Dalane, A. (2021). Evaluering av konsertformidling i høyere utdanning. I E. Angelo, J. Knigge, M. Sæther \& W. Waagen (Red.), Higher Education as Context for Music Pedagogy Research (s. 193-214). Cappelen Damm Akademisk. https://doi.org/10.23865/noasp.119.ch8 Lisens: CC BY-NC-ND 4.0. 
(ØМ). Forfatterne av kapitlet er de samme personene som lærerutdannerne, og bruken av pronomenet «vi» i teksten henspiller dermed på oss, både som forfattere og forskningsdeltagere. Først i kapitlet presenteres faget formidling og konsertproduksjon, og deretter drøftes ulike måter å evaluere performativ kunst på, med særlig søkelys på ønskekvistmodellen. I kapitlets siste del presenteres og drøftes deler av vårt arbeid med $\varnothing \mathrm{M}$ som inkluderer musikkstudentenes vurderinger. Her beskrives også hvordan datamaterialet for studien er generert og analysert, og vi redegjør for vår dobbeltposisjon som lærere og forskere i undersøkelsen. Problemstillingen som leder kapitlet, er: Hvordan vurdere kvalitet $i$ faget formidling og konsertproduksjon ved hjelp av $ø n s k e k v i s t m o d e l l e n ?$ Underliggende forskningsspørsmål til dette er: Hva betyr god kvalitet i denne sammenhengen, og hvordan kan ØM være til hjelp for å undersøke det?

\section{Faget formidling og konsertproduksjon}

Høsten 2006 ble faget formidling og konsertproduksjon etablert som et nytt fag innenfor faglærerutdanning i musikk (bachelor) ved tidligere Høgskolen i Nord-Trøndelag (HiNT), nå Nord universitet, campus Levanger. Faglærerutdanningen i musikk på Levanger er i 2020 en av få utdanningsinstitusjoner i Norge som tilbyr dette faget. Studieplanen for bachelorutdanningen i musikk ved denne institusjonen ble utarbeidet på grunnlag av daværende rammeplan for faglærerutdanning i musikk, dans og drama (Forskrift til rammeplan for faglærerutdanning i musikk, dans og drama (2003); Nasjonalt råd for lærerutdanning, 2017). Lærerutdannerne som var involvert i arbeidet med ny studieplan, mente at rammeplanen manglet et viktig fagområde for studenter som skulle utdanne seg til faglærere i musikk - et fag som tok inn konsertproduksjonsaspektet i utdanningen. Med tanke på hvordan arbeidsmarkedet i grunnskole, kulturskole og det frivillige musikklivet fungerer, mente musikklærerne at det kunne være av stor verdi å gi studentene innblikk i hva som skal til for å utvikle og gjennomføre ulike typer forestillinger og konserter. Slik står faget beskrevet i Nord universitets studieplan (Nord universitet, 2020): 
I Formidling og konsertproduksjon skal studenten få trening i forberedelse, gjennomføring og evaluering av ulike typer konserter, f.eks. interne konserter, skolekonserter, institusjonskonserter og offentlige konserter. Emnet vektlegger formidling for og med barn og unge.

En god scenisk produksjon og framføring kan kreve mer enn musikere på en scene. Musikkseksjonen søkte derfor samarbeid med flere andre fagmiljøer ved universitetet, blant annet multimediefag (både for å dokumentere produksjonene og for å utnytte de mulighetene teknologien gir til å utvikle forestillinger gjennom for eksempel flerkameraproduksjoner og ulike scenografiske løsninger), lærere fra teater- og dramamiljøet, danselærer (bevegelse og koreografi) samt lyd- og lyskompetanse.

Læringsutbyttet i faget uttrykker, slik vi ser det, intensjoner om bredde. Et eksempel er følgende utbytteformulering, som beskrives under «generell kompetanse» $\mathrm{i}$ planen. Her påpekes det at studenten skal få «erfaring med å utvikle kunstneriske prosjekter, der både estetiske, organisatoriske, pedagogiske og tekniske sider er vektlagt» (Nord universitet, 2020). Dette krever bred lærerkompetanse med kunnskap om ulike områder og evalueringsmåter.

Samarbeid med det som tidligere het Rikskonsertene (nå Kulturtanken) ble etablert helt i starten av dette fagets tilblivelse, blant annet ved å benytte en profesjonell produsent fra Rikskonsertene som sensor ved den praktiske eksamenen, tilbud om konserttilbud til våre musikkstudenter og musikklærere samt faglige underveisvurderinger av musikkprodusent fra Musikk i Nord Trøndelag (daværende MiNT). Denne kontakten har på ulike vis vært en bærende faktor i fagets historie og en viktig "retningsgiver» for faget, og kontakten med kulturleddet på fylkesnivå er ivaretatt også i dag. I faget, som gjennomføres i det siste året i bachelorløpet, gjør studentene to større produksjoner, en i høstsemesteret knyttet mot fylkeskommunens bestilling Vrimmel-festivalen ${ }^{1}$ i norddelen av Trøndelag, og den andre en eksamensproduksjon for en definert målgruppe i vårsemestret, de siste årene ved en ungdomsskole i vår kommune. For begge produksjonene kreves mye planleggingsarbeid, med bruk av produksjonsplaner, loggføring, maler for synopsis 
og dreiebok med mer - samt underveisvurderinger hvor blant annet $\varnothing \mathrm{M}$ benyttes som verktøy.

Oppfatning av begrepet «formidling» blir sentral i utvikling av faget formidling og konsertproduksjon. Begrepet formidling brukes på mange områder og på ulike vis. I kunstsammenheng kan vi for eksempel høre om kunstformidling, mens vi i pedagogisk sammenheng ofte hører om blant annet viktigheten av lærerens formidlingsevne, eller det kan her være snakk om formidlingspedagogikk. I musikkdidaktisk litteratur diskuteres også musikkens evne til å formidle (Hanken \& Johansen, 2013, s. 54). Ut fra dette er det ikke bare mennesker som kan formidle, men også abstrakte fenomener, som musikken i seg selv. Kunstformidling påpekes som et vanskelig definerbart og mangetydig fenomen, der den utfordrende oppgaven er å «gi verket liv og tale» (Danbolt, 2014, s. 5). Formidling, både i kunstneriske og i andre sammenhenger, knyttes også til kroppsspråk og kroppens betydning (Østern \& Engelsrud, 2014). Performativ kunst handler ofte om å etablere kontakt med et publikum, noe som forutsetter at også kroppen formidler tydelig, og dette kan også kan ses i sammenheng med multimodalitet i faget vårt. På scenefolk.no (2018) beskrives viktigheten av å signere en «publikumskontrakt» mellom publikum og skuespillere, eller musikere i vårt tilfelle, noe som handler om en bevissthet om dialogen mellom utøvere og publikum og om gjensidig oppmerksomhet på det samme.

Musikkformidling forklares først og fremst som et skandinavisk begrep (Kjølberg, 2010, s. 9). Hvordan musikk formidles, har også vært sentralt hos Rikskonsertene, blant annet gjennom deres nasjonale vurderingsinstans Programrådet (rikskonsertene.no, 2020). Enkelte vil hevde at Rikskonsertene har representert et «verksorientert paradigme» (Holdhus, 2014). Et slikt paradigme bygger på forestillingen om at musikk «transporteres» fra en utøver til en lytter, noe som fra kritisk hold hevdes å frarøve musikkformidlingen relasjonelle aspekter som fremheves som særlig meningsbærende dimensjoner. Relasjoner mellom publikum og utøvere uttrykkes som særlig viktig, blant annet for å skape en «vi-identitet» og for å ivareta det mest meningsbærende i en musikalsk fremføring (Runsjø, 2015). Det relasjonelle aspektet vil også være av betydning i vår diskusjon om kvalitet i faget formidling og konsertproduksjon. Sentralt i realiseringen av faget 
er at studentene på ulike måter skal aktivere publikum i sine konsertproduksjoner, noe også Rikskonsertene (Kulturtanken) har tradisjoner for.

\section{Tidligere forskning om kvalitetsvurdering av kunst}

Ved å søke i søkemotorene ERIC og Oria på «how to evaluate art?» fikk vi noen treff vi vurderer som særlig relevante i vår sammenheng. På Idunn får vi dessuten to treff som omtaler ØM direkte: Hyllands (2012) «The rhetorics of bad quality» og Runsjøs (2015) «Musisk samhandling Musikkframføring og relasjoner». Vi søkte også på ordet «ønskekvistmodellen» og fikk 470 treff i bing.com. Det er imidlertid flere gjengangere blant disse treffene, som for eksempel tidligere Rikskonsertene (med blant annet Produksjonshåndboka), Kulturtanken, Den kulturelle skolesekken (DKS), Kulturskolebanken, Kulturrådet (regjeringen.no), musikkpedagogikk.no og Norsk Forfattersentrum. I det følgende redegjør vi for de kildene vi oppfatter som mest relevante for oss.

Kvalitet i faget formidling og konsertproduksjon dreier seg om subtile, sammensatte og til dels subjektive aspekter. Kompleksiteten i musikkutøvelse beskrives som det å inneha mange kvalitative og skjønnsmessige aspekter, noe som gjør denne utøvelsen krevende å samtale om (Waagen, 2020). I tillegg til utfordrende aspekter for kvalitetsbedømminger står vi, ved å bruke den danske ønskekvistmodellens tre hovedområder - kunnen, villen og skullen - også i fare for å rette for mye oppmerksomhet på enkeltdeler i stedet for å se helheten. Flere studier tematiserer det å evaluere kunstnerisk kvalitet via bestemte kriterier («analytic assessment») $\mathrm{i}$ motsetning til en mer holistisk tilnærming til evaluering. En analytisk kontra holistisk vurderingsform ved å bruke ønskekvistmodellen er relevant å vurdere. Vi vil også problematisere hvorvidt det trenger å være et enten-eller, eller snarere et både-og, og vi er særlig opptatt av hvordan ØM kan fungere som et motiverende vurderingsverktøy. Vurdering beskrives som den mest kraftfulle enkeltkomponenten for læring i formell utdanning, i både positiv og negativ forstand. Positivt kan vurdering fremme læring og motivasjon, mens dårlig vurderingspraksis i verste fall kan underminere både innhold og tilnærminger i undervisning (Boud 
et al., 1999; Denis, 2018). Til sammen danner dette et fruktbart bakteppe for å diskutere hvordan ØM fungerer, med tanke på både underveis- og sluttevaluering (karakterer).

En annen utfordring med kvalitetsvurdering i kunst og kunstuttrykk er hvordan subjektive, ikke-verbaliserte og personlige vektlegginger kan gjøre kriteriegrunnlaget uangripelig og vanskelig diskuterbart (Kjølberg, 2014; Sandberg-Jurström et al., 2021; Waagen, 2021). Det synes viktig å sikte mot å utvikle en felles forståelse eller felles kriterier for hva og hvordan man skal vurdere kvalitet, også i kunstnerisk sammenheng. Kjølberg (2014, s. 18-25) påpeker ØM som et eksempel på å gjøre kriteriegrunnlaget eksplisitt, for eksempel slik denne modellen er brukt i Rikskonsertenes programråd. Som en motsats til bekymringene om subjektive og ikke-artikulerte vurderinger fremmes det også bekymring for en vending mot objektive vurderingsformer og objektive kriterier for å bedømme kunstnerisk kvalitet (Gates, 2017). En fare ved å utelate subjektive perspektiver kan være at kreative aspekter overses. Forholdet mellom prosess og produkt er en tredje utfordring når det gjelder kvalitetsvurdering $\mathrm{i}$ kunstutøvelse. For eksempel påpeker Tolstad (2018) at ensidig oppmerksomhet på verket eller produktet risikerer at vurderingen ikke ivaretar prosessene som har foregått. «Det å produsere kunst- og kulturuttrykk kan defineres som en prosess der en rekke ulike elementer bringes sammen på bestemte måter for å bli til noe», skriver Tolstad, (2018, s. 261), og understreker at produkt og prosess henger sammen i kunstuttrykk. Ut fra dette må vurderinger av og i faget formidling og konsertproduksjon ivareta begge disse aspektene. I undervisningen og studien bak dette kapitlet har det vært en intensjon å se prosess og produkt i sammenheng, noe som har vært muliggjort gjennom at vi som lærere har kunnet følge prosessene fram mot produksjonene.

Det finnes også flere andre utfordringer og fokusområder når det gjelder kvalitetsvurdering i kunstfaglig sammenheng. Flere av disse tematiseres og diskuteres i Leavys Handbook of Arts-Based Research (2018). I denne omtales ulike måter å evaluere kunstuttrykk på. Leavy (2018, s. 575) anbefaler fleksible kriterier, for eksempel med utgangspunkt $i$ Norris (2011) sin «P-modell», der kunstbaserte uttrykk kan vurderes ut fra fire p-er: pedagogy, polititics, poiesis (fra gresk, som enkelt oversatt 
betyr «skape») og public positioning. Lehmann (2005) viser på den ene siden til Kants sensus communis (en felles smak som er «allmenngyldig») og Favrholdts (200o) tanker (i Æstetik og filosofi) om at man ved å benytte ti ulike parametre kan fastsette et verks kvalitetsnivå, og, på den andre siden, til Bourdieus teorier om kulturell kapital og kunsten som felt og Marcuses tanker om kulturell frigjøring og kulturelt demokrati, hvor alle skal kunne bidra med sitt og ikke være passive mottagere av kanonisert kunst (Lehmann, 2005, s. 13-17). Et annet analyseverktøy rettet mot ulike fokusområder omtales av Hylland (2012) på følgende måte: «As an analytical tool, I will make use of the traditional triad in aesthetics, that of artist, art and audience.» Han sier også at ØM «has a comparable triad as functional criteria of artistic quality, holding that this quality is a function of intention, skill and relevance.» Med tanke på kvalitetsvurderinger av konsertproduksjoner kan også forskningsprosjektet DiSko - Dialog i skolen (Kulturtanken, 2020) nevnes. Dette prosjektet ble gjennomført i regi av Kulturtanken (2017-2020) med den hensikt å utvikle nye og bedre praksiser for skolekonserter i Norge i tett samarbeid og med sterk involvering av skolemiljøet som helhet (Holdhus et al., 2019). Videre har musikkpedagogikk.no (2017) utarbeidet en kvalitetsmodell for vurdering i skolen, der de bruker deler av prinsippene fra ØM. Også Litteraturbruket ved Norsk Forfattersentrum (2020) gir eksempler på bruk av ØM.

\section{Ønskekvistmodellen}

Ønskekvistmodellen er utviklet av tre forskere - Langsted, Hannah og Larsen - ved Aarhus universitet, som et verktøy for å kunne evaluere kunstnerisk kvalitet i performativ kunst. Denne modellen er presentert og beskrevet gjennom to utgivelser: «Ønskekvistmodellen: kunstnerisk kvalitet i performativ kunst» (Langsted et al., 2004) og "Ønskekvisten: En håndbog i evaluering af teater, dans og musik» (Langsted et al., 2008). I disse utgivelsene beskriver Langsted og kollegaer hvordan ønsker med verktøyet ønskekvistmodellen er å utvikle et «samtalerum, hvor der på en strugtureret måde kan føres dialog om kunstnerisk kvalitet og om de elementer, denne kvalitet består av» (Langsted et al., 2008, s. 7). Og nettopp et slikt samtalerom var det vi savnet for faget formidling og 
konsertproduksjon. Modellen bygger på de tre begrepene villen, kunnen og skullen, hvor villen omhandler kunstnerens engasjement, uttrykksvilje og kommunikasjonsvilje overfor et publikum, og i hvilken grad publikum opplever denne viljen. Kunnen dreier seg om evner og ferdigheter, men også om profesjonalisme og personlig preg, mens skullen innbefatter det etiske og estetiske samlet. «Det er et spørgsmål om, at kunsten tager os med dybt ind i os selv - og tager os med udenfor os selv» (Langsted et al., 2008, s. 18). Men også et annet aspekt er viktig her, nemlig at kulturinstitusjoner har kulturpolitiske oppgaver de er satt til å gjøre, og som er innarbeidet i deres målsettinger eller $\mathrm{i}$ «deres aftaler med offentlige myndigheter».

Når man skal vurdere i hvilken grad de tre områdene villen, kunnen og skullen er ivaretatt i et kunstverk, en scenisk forestilling eller en konsert, skal man konkretisere dette gjennom en «pilanalyse» bestående av tre piler, en for hvert av de tre områdene. De tre pilene er formet som en ønskekvist, derav navnet. Pilene kan ha ulik lengde for å markere at et område eksempelvis står sterkere enn de andre. Det er dermed ikke slik at «det perfekte kunstverk» oppstår når pilene er like lange på alle områder. Hensikten er heller å markere at utsagn om kvalitet kan legge vekt på ulike områder. Noen legger kanskje mest vekt på enkelte av de tre pilene, mens andre igjen kanskje legger vekt på sammenhengen mellom pilene. En slik sammenheng synliggjøres også ved at pilene uttrykker en slags visuell profil som kan være utgangspunkt for vurderingen.

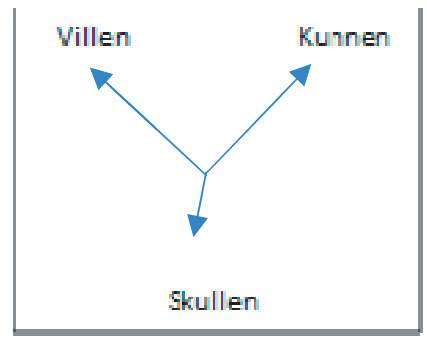

Modell 1

Da vi som musikklærerutdannere begynte å jobbe med ØM høsten 2017, hadde ingen av studentene verken hørt om eller jobbet med denne modellen før. I vårt fagmiljø ved universitetet var vi også uerfarne med 
modellen, og vi fikk først kjennskap til ØM gjennom musikkprodusenten i vårt fylke i 2016. Musikkprodusenten var med i Programrådet i Rikskonsertene (RK), hvor de brukte ØM. En av oss lærere hadde også fătt være med på å benytte ØM som analyse- og evalueringsverktøy på to internasjonale «skolekonsertkonferanser» i Brussel i 2016 og i Porto i 2017 i regi av Young Audiences Music (YAM), noe som ga et godt innblikk i hvordan ØM kan fungere, selv med kort innføring og i et internasjonalt miljø.

Selv om ØM skal gi et åpent samtalerom, betyr ikke det at modellen er verdinøytral. Man kan eksempelvis stille spørsmål ved hvorfor man skal sette søkelys på de tre områdene villen, kunnen og skullen, for hvor kommer disse inndelingene fra, hva kan man legge i disse begrepene, og hva blir ekskludert? Lehmann (2005) gir i boken Kunst og kvalitet - et festskrift til Jørn Langsted en kritisk vurdering av ØM. Hans bakteppe er den store interessen for evaluering og kvalitetssikring som preger samfunnet på flere og flere områder, som en konsekvens av den kulturrelativistiske tidsalderen vi befinner oss i. Lehmann mener forfatterne av $\emptyset \mathrm{M}$ møter seg selv i døren når de på den ene siden med sin modell ønsker å skape et samtalerom hvor man ikke først og fremst skal avgjøre den kunstneriske kvaliteten, men snarere skal gi et tilbud om «at håndtere en mangfoldighet af udtryksformer uden at skulle priviligere» (Lehmann, 2005, s. 19). På den andre siden er imidlertid problemet, ifølge Lehmann, at også skaperne av ØM har sine kulturelle referanser og preferanser som ligger implisitt i modellen, blant annet når de gjør sitt utvalg av de tre hovedområdene kunnen, villen, skullen som indikatorer for å vurdere kunsten. Lehmann (2005, s. 17) beskriver riktignok ønskekvistmodellen som et sympatisk forsøk på å unngå normativitet, men altså uten å lykkes. Han mener også at man gjennom en generaliseringsmodell står i fare for ikke å behandle de særegenhetene som ulike kunstverk og kunstuttrykk kan ha, og dermed kan man ekskludere essensielle genuine områder i kunstvurderingen (jamfør tidligere nevnt problematikk knyttet til holistisk kontra analytisk evaluering).

Kvarv spør også om ikke enhver samtale er verdimessig eller diskursivt basert. Han mener ellers at villen er «antakelig både det mest problematiske begrepet, og dessverre det mest uavklarte av de tre begrepene som 
det gjøres rede for i boken» (Kvarv, 2004, uten paginering). Her problematiserer han forfatternes fremstilling av et «enten-eller-forhold» mellom «privat vilje» og en «vilje på kunstens egne premisser», som han synes er svært problematisk. Kvarv uttrykker også at han savner problematiseringer av "grensetilfellene», hvor de kunstneriske kvalitetsdiskursene utfordres innenfra, av de performative kunstnerne selv (2004). Dette har vi også kjent litt på, og vi har derfor i vårt «samtalerom» med studentene forsøkt å sette søkelys på de kunstneriske prosessene i produksjonene med både et innenfra- og et utenfrablikk - blant annet ved at studentene skal være med på å samtale om og vurdere hverandres produksjoner.

\section{Metodologi og metoder}

Vårt forskningsarbeid er i hovedsak knyttet til kvalitativ forskning, med nær tilknytning til aksjonslæring, gjennom at vi har forsket på egen praksis og har forsøkt å innhente ny kunnskap og kompetanse sammen med studentene (primærbrukerne) (Gjøtterud et al. 2017, s. 46 ff). Vi har imidlertid også kvantifisert deler av datamaterialet i forbindelse med spørreundersøkelsene for å tydeliggjøre datamaterialet med tall og tabeller.

For å komme nær studentenes egne utsagn har vi i vesentlig grad benyttet direkte sitater, og vi har gjort et utvalg av det vi opplever som mest relevant for vårt hovedspørsmål. Det samlede materialet er videre analysert gjennom en hermeneutisk prosess, der tolkninger og forståelser av materialet fortrinnsvis er gjort av oss lærerforskere. Vi har imidlertid forsøkt å kvalitetssikre og nyansere analysearbeidet, gjennom dialoger mellom oss lærere og studentene, blant annet med oppfølgingsspørsmål, og samtaler mellom oss lærerforskere der vi blant annet har stilt ulike spørsmål til hverandre.

At vi har en fot i både musikklærer- og forskerverdenen, gjør at vi tolker og forstår faget og studentene ut fra forskjellige perspektiver og ser deler og helheter i en kontinuerlig veksling, og det gjør at våre perspektiver og forståelser justeres underveis. Dette kan forklares som en hermeneutisk spiraltenkning (Gadamer, 2010). Metodisk har det derfor også her vært en fordel å være to lærerforskere, for da har vi kunnet ha dialoger om egne forståelser og tolkninger. Vi har også kunnet forsøke å 
se materialet gjennom studentenes ulike perspektiver, ettersom de også har både kunstner- og lærerperspektiv i dette faget.

Musikkstudentene ved Nord universitet har jobbet med ØM 2017-2019, og datamaterialet vårt er hentet fra skriftlige rapporter fra Vrimmelfestivalen (gjennomført i november 2017, men levert i 2018), og fra spørreundersøkelser gjennomført med to ulike studentkull (våren 2018 og høsten 2019). Det ble tatt videoopptak av fire ulike produksjoner, samt av et gruppeintervju med studentene på en av produksjonene som ble gjennomført i etterkant av Vrimmel-festivalen 2017.

\section{Studentrapport}

I studentrapporten skulle studentene vurdere de ulike framføringene på Vrimmel-festivalen (november 2017) ved bruk av ØM. Slik beskriver en av studentene dette:

Villen var kanskje den delen av ynskjekvistmodellen som varierte mest gjennom veka. Dette var resultat av publikumsengasjement, kor utkvilde vi var, og stemninga kombinert. Der det var større publikumsmengder, eller der engasjementet hjå publikum var stort, reflekterte over i gruppa båe i energi og innleving på scena.

Med tanke på skullen skriver en student:

Skullen, nett som villen, har variert gjennom veka. Førestillinga slo godt an blant dei yngre elevane. I tilfella der vi framførte for 5.-7. trinn, var det jamt over mindre deltaking og engasjement i publikum, og det vart mindre samspel mellom sal og scene. I tilfella kvar publikum var 1.-4. eller 1.-7., vart energi og stemning betre båe i salen og på scena.

Hvordan vurderte studentene seg selv med hensyn til kunnen? En student skriver:

Kunnen var jamt over stor. Alle i gruppa hadde overskott nok til å utøve det musikalske stoffet, samt å formidle skodespel og speleglede. Repertoaret satt godt nok i fingrane og hovudet til at førestillinga kunne utførast godt, sjølv om energi og motivasjon ikkje alltid var på topp. 


\section{To spørreundersøkelser (2018 og 2019)}

Vi gjennomførte to åpne spørreundersøkelser med studentene våren 2018 og høsten 2019, om bruken, verdien og utfordringer knyttet til å jobbe med ØM. 50 prosent (10 av 20) av studentene svarte på undersøkelsen i 2018. De to spørreundersøkelsene har noen ulike spørsmål, men i begge ber vi studentene svare på hvordan de opplever det å forstå og anvende de tre kategoriene villen, kunnen og skullen. I den første (våren 2018) er vi eksempelvis ute etter å se på bruken av ØM ut fra fem ulike aspekter (figur 1).

I denne undersøkelsen spurte vi blant annet: Hvordan vurderer $d u$ bruken av ØM ved vurdering av kunstuttrykk/konserter med hensyn til:

\begin{tabular}{|l|c|c|c|c|}
\hline & I liten grad & I noen grad & I høy grad & I svært høy grad \\
\hline Tydelighet / klare kategorier & $10 \%$ & $70 \%$ & $20 \%$ & \\
\hline Kan gi vurderingen et språk & $20 \%$ & $40 \%$ & $40 \%$ & \\
\hline Sier noe om kvalitet & $20 \%$ & $40 \%$ & $40 \%$ & \\
\hline Sier noe om mål & $10 \%$ & $50 \%$ & $40 \%$ & \\
\hline Egnet utgangspunkt for diskusjon & $20 \%$ & $40 \%$ & $20 \%$ & $20 \%$ \\
\hline
\end{tabular}

Figur 1 Undersøkelse 2018

På spørsmålet «i hvilken grad er ønskekvistmodellen egnet som grunnlag for samtale og karaktervurdering», svarer 40 prosent positivt, mens 60 prosent svarer negativt.

Med hensyn til bruken av de tre begrepene kunnen, villen og skullen viste undersøkelsen fra 2018 at skullen var klart mest utfordrende å forholde seg til.

I den andre undersøkelsen (høsten 2019) svarte 76 prosent (16 av 21) av studentene. 75 prosent svarer her at de «i noen grad» hadde blitt kjent med modellen. 80 prosent sier at de «i noen grad» ønsker å bli bedre kjent med den. På spørsmål om hvilke fordeler de mener modellen kan ha ved vurdering av kunstuttrykk/konserter, fikk vi blant annet disse svarene: «Refleksjon over eget arbeid», «saklig og oversiktlig diskusjon - å diskutere kunst og kreativitet blir fort uoversiktlig og svært subjektivt», «klassifisering av fokus», «ryddig refleksjon i etterkant».

Videre var ett av spørsmålene: Modellen beskriver tre dimensjoner: villen, kunnen, skullen. I hvilken grad opplever du hver av disse som utfordrende eller vanskelig å beskrive? 


\begin{tabular}{|l|c|c|c|c|}
\hline & Lite utfordrende & Noe utfordrende & Nokså utfordrende & Svært utfordrende \\
\hline Villen & $50 \%$ & $19 \%$ & $19 \%$ & $12 \%$ \\
\hline Kunnen & $12 \%$ & $57 \%$ & $19 \%$ & $12 \%$ \\
\hline Skullen & $6 \%$ & $38 \%$ & $44 \%$ & $12 \%$ \\
\hline
\end{tabular}

Figur 2 Undersøkelse 2019

Her ser vi, i likhet med svarene fra undersøkelse 1 (2018), at det er skullen som oppleves vanskeligst å forholde seg til.

81 prosent sier de «i noen grad» ønsker å bli bedre kjent med modellen. Noen av deres kommentarer er: «Bra som verktøy eller utgangspunkt for diskusjon», «saklig og oversiktlig diskusjon», «å diskutere kunst og kreativitet blir fort uoversiktlig og svært subjektivt», «klassifisering av fokus», «ryddig refleksjon i etterkant».

\section{Videopptak fra Vrimmel - og intervju i etterkant}

Under evalueringen av Vrimmel 2017 ble videoopptak av alle produksjonene vist, kommentert og drøftet, med unntak av en, der ikke alle studentene ønsket å vise fram sin ferdige produksjon for hele klassen. Dette måtte vi selvsagt respektere (jamfør etiske retningslinjer for forskning NESH, 2016), og vi hadde også på forhånd snakket om at selv om alle produksjonene skulle filmes (av studenter fra mediafag) for å kunne brukes som læringsverktøy for de respektive gruppene i ettertid (etter ønske fra både klassen og oss lærere), var vi hele tiden tydelige på at de gruppene som ikke ville vise fram sine produksjoner for klassen, skulle slippe det. Hver gruppe kunne uansett se dem gruppevis etterpå. I intervjuet i etterkant sier en av studentene (som var på en gruppe som lot sin produksjon bli vist for hele klassen):

Det kan jo være litt ekkelt å sjå seg sjøl på video, men nå er jeg jo blitt vant til det [latter]. Men de tinga æ trur æ gjær stort, dem er ikke så stor likevel ... bevegelser, ansiktsuttrykk og sånt.

Av andre ting som kan nevnes fra intervjuet med den ene studentgruppen, kan denne studentrefleksjonen over formidling og det skuespillerfaglige vise noe av det tverrfaglige i faget: 
Æ huske hu [produsenten som var inne og vurderte produksjonene] sa noe med at alle følelsan må være ti gang større enn dokker tenke. Det satt seg litt fast hos meg i alle fall - ok, hvis vi er glade, så må vi vær veldig glade!

\section{Drøfting}

Gjennom veiledning av produksjonsprosessene har vi hatt som intensjon at studentene skal bruke ØMs tre dimensjoner til drøfting og samtale om aktuelle løsninger, spesielt med tanke på en bevisstgjøring av hvordan en forestilling kan nå et bestemt publikum på en god måte.

Vi ser i studentrapportene at studenter ser tydelig kobling mellom villen og skullen. Det ene kan påvirke det andre, og usikkerhet og sårbarhet i en gruppe, for eksempel ved uteblitt publikumsrespons, kan være stor. Usikkerheten kan også bre seg, slik at viljen blir utfordret av skullen. Vi ser videre, i begge spørreundersøkelsene, at det er skullen som oppleves vanskeligst å forholde seg til. På spørsmålet «i hvilken grad er ønskekvistmodellen egnet som grunnlag for samtale og karaktervurdering?» svarte 40 prosent positivt, mens 60 prosent svarte negativt i spørreundersøkelse 1. Dette opplever vi noe overraskende, særlig ettersom 80 prosent svarte positivt (når vi slår sammen «i noen grad» og «i høy grad») på at ØM var egnet utgangspunkt for diskusjon. Det kan tyde på at studentene er positive til ØM som diskusjonsverktøy, men at de har en viss skepsis til å bruke $\varnothing \mathrm{M}$ til karaktervurdering (og spørsmålet burde nok ha vært todelt). Denne skepsisen til ØM og karaktervurdering er interessant, særlig med tanke på at vi i ettertid så eksempler på at ØM fungerte godt som hjelpemiddel til å drøfte og sette karakterer ved eksamen våren 2018. Her brukte den eksterne sensoren ØM som hjelpemiddel, og i samtale med studentene etterpå viste det seg at det var godt samsvar mellom sensors vurderinger av kunnen, villen og skullen - og studentenes vurdering av seg selv og sin gruppe - ut fra ØM.

Fra videoopptakene er det særlig nyttig å se hva studentene tenker om formidling når det gjelder tydelighet, fokus, overdrivelser, eller om «hvordan fenomener som å være til stede, oppleve, sanse, kjenne, tenke og handle skjer i og fra kroppen» (Østern \& Engelsrud, 2014, s. 67). Men studentene trenger å bli bevisstgjort i enda større grad på hva det vil si å formidle, og på 
hvordan dette skjer. Veien fram dit handler ikke om å snakke om det, men om å gjøre det! Hva gjør du på scenen for å skape god formidling? Hvilke virkemidler har du tilgjengelig for å forbedre formidlingen? Å praktisere, øve, få veiledning på formidling og performativ bevissthet - og å se seg selv - er essensielt. En student sier: «Men de tinga æ trur æ gjær stort, dem er ikke så stor likevel ... bevegelser, ansiktsuttrykk og sånt.»

Etter mange kull med studenter ser man som undervisere ofte at studentenes oppmerksomhet i vesentlig grad har vært rettet mot den musikalske utøvelsen og det sceniske - lysshowet, den perfekte lyden og prestasjonen på eget instrument. Våre erfaringer viser også at de studentgruppene som klarer å jobbe godt sammen og få i gang gode prosesser, også ender opp med de beste produksjonene og presentasjonene og gjerne de beste karakterene. Særlig interessant er det at disse resultatene ikke trenger å ha noen direkte sammenheng med deres kompetanse på hovedinstrumentet (som altså mange av våre studenter er særlige opptatt av), men studentene klarer å gjøre hverandre gode, enten det dreier seg om bruken av hoved- og biinstrument, å forfatte et manus, å bygge god dramaturgi, å komponere musikk eller å vise gode scenepresentasjoner. Dette viser hvor viktig villen til samarbeid og fellesskapsfølelse er for å jobbe sammen mot et godt resultat der «målgruppens skullen» er i fokus.

Hvis vi skal gi en generell ønskekvistanalyse av studentenes produksjoner, kan vi si at vi ofte opplever at både villen og kunnen er på et godt nivå, mens skullen ofte blir litt mangelfull eller «kort».

Studentene har etter vårt syn generelt mer søkelys på selve musikken, sitt eget instrument og det tekniske, og mindre på hvordan man skal formidle et innhold eller budskap til publikummet, og dermed kan de få problemer med å få «signert publikumskontrakten». Hvordan kan vi forsterke deres oppmerksomhet på skullen? Det er for det første viktig at vi lærerutdannere retter mer oppmerksomhet på formidlingsaspektet for å bevisstgjøre våre studenter mer på både hva formidling innebærer, og hvordan man bedre kan øves opp i å bli en god konsertformidler. Studentene måtte trenes i å bli mer bevisst på å nå sitt publikum, og på å forstå at deres villen bør ses i nærmere sammenheng med skullen, eller sagt på en annen måte: De skal lære å se sammenhengen mellom $h v a$ de ønsker å formidle og hvordan de skal formidle det til en bestemt målgruppe. 
Faget formidling og konsertproduksjon gir studentene en unik mulighet til å utforske seg selv og sine medstudenter, både på scenen i felles formidling og fra publikumsposisjonen. For mange studenter gir faget svært viktige erfaringer innen både pedagogiske og utøvende områder, jamfør samtaler og evalueringer. Trening i å evaluere og det å få økt bevissthet på hvilke kompetanser og ferdigheter som må være til stede for å kunne skape kunstneriske produksjoner som berører ett publikum, er en krevende prosess: Som en av studentene sier: «Å diskutere kunst og kreativitet blir fort uoversiktlig og svært subjektivt.» Vår erfaring er at studenter gjennomgående får for lite trening og veiledning i evalueringsprosesser. Innenfor rammene av faget formidling og konsertproduksjon (et stort fag med begrenset timetall) blir det gjerne for sjelden tid til gode og grundige nok prosesser for drøftinger og evalueringer.

Å evaluere krever erfaring og innsikt. Hernes (2014, s. 201) forklarer det å ha innsikt som å omhandle både håndverksmessig, teknisk og historisk kunnskap og, ikke minst, fysiske erfaringer. Innsikt uttrykkes, jamfør Hernes, ikke bare gjennom ord og tale, men også gjennom fremvisning og samhandling. Ut fra dette blir mengdetrening, refleksjonsarbeid og modning essensielt i dette faget.

Vi har tidligere problematisert søkelyset på ØMs villen, kunnen og skullen - og vi lærere ser også faren med at noe kan bli ekskludert i en slik utvelgelse (jf. Lehmann, 2005). Videre kan vi også spørre om modellen - eller lærerne - gir rom for studentenes egne verdier og kulturelle preferanser? Dette med smak, preferanser og tradisjoner kan nemlig sies å være en viktig del av både villen, kunnen og skullen. Kvarv (2004) sier: «Performativ kunst som felt og subfelt har definitivt bestemte egenskaper som påkaller bestemte kvalifikasjoner, ferdigheter og kulturell kapital hos den utøvende kunstner», og han sammenligner dette med Bourdieus feltteori. Her vil også Bourdieus habitus-begrep være relevant, og det er grunn til å stille spørsmål ved hva ØM eller vi lærere legger i kvalitet, og hvilket innhold og hvilke presentasjonsformer vi tenker vil passe for de ulike målgruppene, jamfør skullen. Det kan også stille spørsmål ved om bruken av ØM bringer oss nærmere svaret på hva som er kvalitet i kunst. Kan ØM like godt ha en forførende virkning, og lede oss og studentene til å tro at vi er kommet nærmere svaret på hva som er kvalitet i 
kunstformidlingen? Dette berører Lehmanns sentrale poeng i hans kritikk av ØM: «Her dreier ikke diskusjonen seg lenger om man skal innta et 'absolutisk eller relativistisk udgangspunkt for kvalitetsbestemmelserne, men om hvordan vi skal behandle kvalitetsspørsmål når «relativismen har sat sig som et grundvilkår» (Lehmann, 2005, s. 13).

Det som driver kunstneren, er sammensatt. Kvarv (2004) peker på villen som det mest problematiske begrepet, med private motiver, sosiale motiver, bevisste og ubevisste lengsler og uttrykksbehov vevd inn i hverandre på intrikate måter. Dette berører også spørsmålet om identitet. I boken Kunstner eller loerer? presenteres profesjonsdilemmaet for kunstnerloreren på både individuelt, kollektivt, institusjonelt og politisk nivå (Angelo \& Kalsnes, 2014, s. 31). Det er altså snakk om «mange identiteter» på ulike nivåer, og selv om vi lærere tenker at ØM kan være avklarende og forholdsvis enkel, er den i realiteten sammensatt, også fordi lærernes kulturelle kapital og profesjonsidentitet implisitt blir en viktig del av kvalitetsvurderingene, både i drøftinger med studentene og i sluttevalueringer.

Vi forstår innvendingen til Kvarv, om at villen var «antakelig både det mest problematiske begrepet, og dessverre det mest uavklarte av de tre begrepene», men i praktisk bruk er våre erfaringer, i likhet med studentenes, at skullen er det vanskeligste begrepet å forholde seg til når det gjelder både å forstå det og å anvende det. Dette er for oss et svært viktig område som man ikke kan unnlate å forholde seg til. Utøvere på en scene har ansvar for å forholde seg bevisst til bestemte målgrupper med ulike «formidlingsnøkler» - og i et større perspektiv har lærerutdanning som kulturinstitusjon både kulturpolitiske og samfunnsdannende oppgaver. Lærerutdannere har jamfør forfatterne av ØM «aftaler med offentlige myndigheter» (Langsted et al. 2008, s. 18). Våre studenter lager eksempelvis produksjoner som skal tilpasses ulike målgrupper, fra barn (barnehage, grunnskole) til voksne og eldre (blant annet eldresenter), ut fra lærerutdanningens samfunnsmandat (med lover, planverk, læringsutbytter med mer).

Et spørsmål vi har stilt oss er om ikke skullen krever ytterligere klargjøringer? Bør skullen «operasjonaliseres» med flere underpunkter? Her ser vi for oss ulike punkter som kan knyttes til både vårt samfunnsoppdrag, kjennskap og forstålse for ulike målgrupper, publikumskontrakten og kanskje kan også publikumsdelaktighet være et underpunkt under 
skullen? Men samtidig må vi også se skullen i sammenheng med villen (for eksempel vilje til å opptre for det gitte publikum og ivareta «samfunnsoppdraget») eller kunnen, som også kan handle om formidlingskompetanse. Dette er også Kjølberg inne på i den tidligere nevnte forskningsstudien av Rikskonsertene, hvor hun har noen kritiske innspill til hvordan Programrådet i Rikskonsertene har brukt ØM. Hun forteller: «Jeg opplevde et misforhold på flere nivåer til hvordan man på den ene siden formulerer seg om - og på den andre siden brukte - ønskekvistmodellen.» Hun peker blant annet på vurdering av villen, kunnen og skullen, i stedet for å vurdere helheten (Kjølberg, 2014, s. 45), jamfør tidligere problematisering av en analytisk kontra en holistisk vurderingsform

Kvarv (2004) savner ellers problematiseringer av, hvor de kunstneriske kvalitetsdiskursene utfordres innenfra. Dette har vi også kjent litt på, og vi har derfor i samtalerommet med studentene forsøkt å sette søkelys på de kunstneriske prosessene i produksjonene - med både et innenfra- og et utenfrablikk. Det er imidlertid ingen enkel øvelse å skulle vurdere seg selv eller medstudenter ut fra kunstneriske valg og formidlingsevner. Dette trengs det derfor mye trening i.

Det er da også mye sterkere tradisjoner på å studere kunstnere eller særlig kunstverket utenfra (å studere eller forske på kunsten) enn selv å være en del av kunsten og vurderingsprosessene (å forske med eller gjennom kunsten) (Østern, 2017, s. 9). Her kan vi også dra inn ulike perspektiver vi lærereutdannere har på å jobbe med dette faget, hvor vi både skal være pedagoger og kunstlærere og vurdere kunstuttrykk sett i forhold til formidling til en bestemt målgruppe, men også samtidig tenke på studentenes egenart og utvikling, jamfør emnebeskrivelsen for faget formidling og konsertproduksjon: «Forholdet kunstner og lærer er sentralt i undervisningen» (Nord universitets studieplan, 2020).

\section{Konklusjon og veien videre}

Vår problemstilling var: Hvordan vurdere kvalitet $i$ faget formidling og konsertproduksjon ved hjelp av ØM? Vi har forsøkt å vise at formidling og konsertproduksjon er et komplekst fag, der studentene skal utvikle kunstneriske prosjekter hvor både estetiske, pedagogiske og tekniske 
sider skal vektlegges. Dette kan være et krevende «spagatløp» for både studenter og lærerutdannere, både når det gjelder å utøve faget - og ikke minst det å evaluere de ulike områdene.

$\varnothing \mathrm{M}$ er ment å favne bredt som samtalerom og evalueringsverktøy, jamfør Produksjonshåndboka til Rikskonsertene: «Modellen vil kunne brukes på enkeltkunstverk og på kulturinstitusjoners samlede liv» (Rikskonsertene/ Programrådet (2015). Rikskonsertene sier ellers at «[å] bestemme et kunstnerisk uttrykks villen, kunnen og skullen, krever både viten og analyse» (Rikskonsertene/Programrådet (2015). Vår erfaring er at det også trengs modningstid for å lære seg å bruke ØM, og særlig er skullen krevende.

Vi har sett viktigheten $\mathrm{i}$ at studentene utvikler evnen til å ha søkelys på både villen, kunnen og skullen, og at dette synes å lykkes best der studentene samarbeider godt, drar lasset i samme retning og har det fint sammen. Lehmann (2005) mente at skaperne av ØM møter seg selv i døren når de på den ene siden ønsker å skape et samtalerom hvor man ikke først og fremst skal avgjøre den kunstneriske kvaliteten, men på den andre siden har sine kulturelle referanser og preferanser som ligger implisitt i modellen. Denne kritikken kan absolutt være et spennende utgangspunkt for en større diskusjon mellom studenter og lærerutdannere i faget formidling og konsertproduksjon, om både kulturelle og ideologiske valg - og om kvalitet i evaluering av kunst.

Som musikklærerutdannere ser vi at det er behov for et samtalerom og et analyse- og evalueringsverktøy som ØM. Selv om man kan stå i fare for å miste det holistiske av syne ved å rette oppmerksomheten mot spesielle evalueringskriterier, peker forskning mot at det kan gi gode effekter å tydeliggjøre spesifikke aspekter ved musikkutøvelse, og å beskrive hva som konstituerer akseptable former for utøvelse (Sandberg-Jurström et al., 2021). Vi oppfatter heller ikke at det trenger å være noe enten-eller her, siden vi gjennom arbeidet med ØM og oppmerksomhet på kunnen, villen og skullen har erfart økt bevissthet og et større helhetssyn, både på faget og på måter å evaluere på.

Flertallet (81 prosent) av studentene sier i den siste spørreundersøkelsen (ref. undersøkelse 2019) at de ønsker å bli bedre kjent med modellen, og vår erfaring er at studenter gjennomgående får begrenset trening og veiledning i evalueringsprosesser. Her ser vi at $Ø \mathrm{M}$ har bidratt i positiv 
retning, som et konstruktivt bidrag i arbeidet med evaluering $\mathrm{i}$ faget formidling og konsertproduksjon. Vi vil derfor jobbe videre med ØM og sammen med våre studenter forsøke å videreutvikle $\emptyset \mathrm{M}$ samtidig som vi utvikler flere måter å evaluere og forbedre faget på, i aksjonsforskningens ærend - og gjerne i et større praksisfellesskap.

\section{Referanser}

Angelo, E. \& Kalsnes, S. (Red.). (2014). Kunstner eller loerer? Cappelen Damm Akademisk.

Boud, D., Cohen, R. \& Sampson, J. (1999) Peer learning and assessment. Assessment and Evaluation in Higher Education, 24(4), 413-426. https://citeseerx.ist.psu.edu/ viewdoc/download?doi=10.1.1.203.1370\&rep=rep1\&type $=$ pdf

Danbolt, G. (2014). Hva er formidling? Kunstløftet, 3. https://issuu.com/norsk_ kulturrad/docs/kunstloftet_3_avis_final_1

Denis, J. M. (2018) Assessment in music: A practitioner introduction to assessing students. Applications of Research in Music Education, 36(3), 20-28. https://doi. org/10.1177/8755123317741489

Favrholdt, D. (2000). Estetik og filosofi. Høst \& Søn.

Forskrift om rammeplan for PELU. (2013). Forskrift om rammeplan for treårige faglærerutdanninger i praktiske og estetiske fag (FOR-2013-03-18-290). Lovdata. https://lovdata.no/dokument/SF/forskrift/2013-03-18-290

Forskrift til rammeplan for faglærerutdanning i musikk, dans og drama (FOR2003-04-03-613). Lovdata. https://lovdata.no/dokument/LTI/forskrift/ 2003-04-03-613

Gadamer, H.-G. (2010). Sannhet og metode. Grunntrekk i en filosofisk hermeneutikk. Pax.

Gates, L. (2017). Embracing subjective assessment practices: Recommendations for art educators. Art Education, 7o(1), 23-28, https://doi.org/10.108o/ooo43125.2017.1247565

Gjøtterud, S., Hiim, H., Husebø, D., Jensen, L. H., Steen-Olsen, T. H. \& Stjernstrøm, E. (Red.). (2017). Aksjonsforskning i Norge: teoretisk og empirisk mangfold. Cappelen Damm Akademisk.

Hanken, I. M. \& Johansen, G. (2013): Musikkundervisningens didaktikk. Cappelen Damm Akademisk.

Hernes, L. (2014). Pedagogen og den kunstneriske prosessen. I E. Angelo \& S. Kalsnes (Red.), Kunstner eller loerer? (s.195-204). Cappelen Damm Akademisk. Holdhus, K. (2014). Stjerneopplevelser eller gymsalsestetikk? En studie av kvalitetsoppfatninger i skolekonsertpraksiser [Doktorgradsavhandling]. Aarhus universitet. 
Holdhus K., Waade, R., Romme, J. C., Almås, R. \& Espeland, M. (2019). Innovasjonsprosjektet Skole og konsert - fra formidling til dialog (DiSko). Erfaringsrapport 2019. https://www.diskoprosjektet.no/rapporter

Hylland, O. M. (2012). The rhetorics of bad quality. Nordisk kulturpolitisk tidsskrift, 15(1), 7-26. https://www.idunn.no/file/pdf/54845170/the_rhetorics_of_bad_quality.pdf

Irwin, R. L., LeBlanc, N., Ryu, J. Y. \& Belliveau, G. (2018). A/r/tography as living inquiry. I P. Leavy (Red.), Handbook for arts-based research (s. 37-53). Guilford Press.

Kjølberg, K. (2010). Rom for romanser [Doktorgradsavhandling, Norges musikkhøgskole] https://nmh.brage.unit.no/nmh-xmlui/bitstream/ handle/11250/172408/Materie_Kj\%C3\%B8lberg_ny.pdf? sequence $=1$ \&isAllowed $=y$

Kjølberg, K. (2014). Skolekonserter av høy kvalitet. En studie av Rikskonsertenes programråds vurderinger og kvalitetssikring av skolekonsertproduksjoner. https://static1.squarespace.com/ static/57c6b752440243071d365d28/t/5857b1596b8f5b310oob21d1/148214206859o/ Skolekonserter $+\mathrm{av}+\mathrm{h} \% \mathrm{C} 3 \% \mathrm{~B} 8 \mathrm{y}+\mathrm{kvalitet}+\% 28 \mathrm{Kj} \% \mathrm{C} 3 \% \mathrm{~B} 8 \mathrm{lberg} \% 29 . \mathrm{pdf}$

Krogtoft, M. \& Sjøvoll, J. (Red.). (2018). Masteroppgaven i loererutdanninga. Cappelen Damm Akademisk.

Kvarv, S. (2004). Ønskekvistmodellen: kunstnerisk kvalitet i performativ kunst. Nordisk kulturpolitisk tidskrift, 7(1), 130-136.

Kulturtanken. (2020). DiSko-prosjektet. 20.05.2020. https://www.diskoprosjektet.no/

Langsted, J., Hannah, K. \& Larsen, C. R. (2004). Ønskekvistmodellen. Kunstnerisk kvalitet i performativ kunst. Klim.

Langsted, J., Hannah, K. \& Larsen, C. R. (2008). Ønskekvisten: En håndbog i evaluering af teater, dans og musik. Klim.

Leavy, P. (Red.). (2018). Handbook for arts-based research. Guilford Press.

Lehmann, N. (2005). Kunstvurdering i en kulturrelativistisk tidsalder: substantiverede modalverber eller selvreferentielle iagttagelsesoperationer. I J. Szatkowski (Red.), Kunst og kvalitet - et festskrift til Jørn Langsted (s. 13-38). Klim.

Musikkpedagogikk.no. (2017, 9. juni). Ønskekvistmodellen. https://musikkpedagogikk. no/onskekvistmodellen/

Nasjonalt råd for lærerutdanning. (2017). Nasjonale retningslinjer for treårige fagloererutdanninger i praktiske og estetiske fag. https://www.uhr.no/_f/p1/ ie425b925-ad1c-456o-9d7c-4f7f8535fb2e/nasjonale-retningslinjer-for-trearigefaglarerutdanninger-27102017-etter-vedtak-nrlu.pdf

NESH (2016). Forskningsetiske retningslinjer for samfunnsvitenskap, humaniora, juss og teologi. Den nasjonale forskningsetiske komite for samfunnsfag og humaniora (NESH). https://www.etikkom.no/forskningsetiske-retningslinjer/ Samfunnsvitenskap-jus-og-humaniora/

Nord universitet. (2020). Formidling og konsertproduksjon MFL37o. https:// www.nord.no/no/Student/studieplaner/2020h/5/Sider/MFL37ov1. aspx\#\&acd=Beskrivelse+av+emnet-header 
Norsk Forfattersentrum. (2020, 10. oktober). Norsk Forfattersentrum: Litteraturbruket. https://www.forfattersentrum.no/litteraturbruket/produksjoner/

Norris, J. (2011). Towards the use of the 'great wheel' as a model in determining the quality and merit of arts-based projects (research and instruction). International Journal of Education and the Arts, 12, 1-24.

Rikskonsertene.no. (2015). Programrådet. http://www.produksjonshandboka.no/ artikler/2015/10/15/nskekvistmodellen-et-sammendrag?rq=\% $\mathrm{C}_{3} \%$ B8nskekvistmodell

Rikskonsertene. (u.å.). Ønskekvistmodellen - et sammendrag. https://rikskonsertene. wixsite.com/produksjonshandbok/nskekvistmodellen--et-sammendrag

Runsjø, P. (2015). Musisk samhandling - musikkframføring og relasjoner. Uniped, 38(1). https://www.idunn.no/uniped/2015/o1/musisk_samhandling_-_ musikkfremfoering_og_relasjoner

Sandberg-Jurström, R., Lindgren, M. \& Zandén, O. (2021). A Mozart concert or three simple chords? Limits for approval in admission tests for Swedish specialist music teacher education. I E. Angelo, J. Knigge, M. Sæther \& W. Waagen (Red.), Higher education as context for music pedagogy research (s. 19-40). Cappelen Damm Akademisk

Scenefolk.no. (2018). Kontrakten mellom publikum og skuespiller. http://scenefolk.no/ nb/artikler/2016/og/kontrakten-mellom-publikum-og-skuespiller

Tolstad, I. M. (2018). Det her va jævli bra! Om kvalitetsvurderinger i kunstneriske arbeidsprosesser. I J. F. Hovden \& Ø. Prytz (Red.), Kvalitetsforhandlinger

(s. 261-282). Fagbokforlaget.

Universitets- og høgskolerådet. (2018). Nasjonale retningslinjer for loererutdanningene https://www.uhr.no/temasider/nasjonale-retningslinjer/nasjonale-retningslinjerfor-larerutdanningene/

Vrimmel. (u.å.). Om Vrimmel. Hentet 8. april 2018 fra https://vrimmel. trondelagfylke.no/om-vrimmel/

Waagen, W. (2021). Vurderingskriterier i utøvende musikk - et verktøy for pålitelig vurdering av studentenes bachelorkonsert? I E. Angelo, J. Knigge, M. Sæther \& W. Waagen (Red.), Higher education as context for music pedagogy research (s. 41-64). Cappelen Damm Akademisk.

Yam Audiences Music. (u.å.) The search for shining eyes. http://jmi.net/programs/yam Østern, A.-L. (2014). Dramaturgi i didaktisk kontekst. Fagbokforlaget.

Østern, T. P. \& Engelsrud, G. (2014). Læreren-som-kropp. Kontakt, kommunikasjon og ledelse som lærerkropp. I A.-L. Østern, (Red.), Dramaturgi i didaktisk kontekst (s. 67-85). Fagbokforlaget.

Østern, T. P. (2017). Å forske med kunsten som metodologisk praksis med aesthesis som mandat. Journal for Research in Arts and Sports Education, Special Issue: «Å forske med kunsten» 1, 7-27. 0.23865/jased.v1.982 


\title{
CHAPTER 9
}

\section{Dilemmaer i skandinavisk korlederutdanning}

\author{
Dag Jansson \\ OsloMet - Storbyuniversitetet

\section{Anne Haugland Balsnes} \\ Universitet i Agder
}

\begin{abstract}
Within higher education, programmes in choral conducting are offered of varying kinds and at different levels, from dedicated programmes to single courses that are embedded in other music programmes. The choral practice field is varied; choral leadership is partly a generic music competence and partly a profession. The variety and social reach of the choral movement suggest that the educational offering in choral conducting should be manifold in type and quantity in order to supply the practice field with qualified conductors.

In this chapter we take a renewed look at material from three previous studies: (1) a mapping of Scandinavian choral leader education, based on document analysis and interviews with tutors and newly graduated conductors; (2) a quantitative survey on choral conducting competencies, where more than 600 conductors in Norway, Sweden, and Germany participated; and (3) an interview study of twenty Norwegian choral conductors on their professional careers. Although the findings from these studies were salient enough, the implications for choral conducting education were not equally clear. The point of departure for this chapter is that this is due to a series of difficult trade-offs, and we ask the question: What dilemmas do we face when educating choral conductors, and how might we understand these in light of the composite data? The material is analysed by drawing on established pedagogic categories, Wenger's theory of communities of practice (1998), Jansson's competence model for choral conductors (2018), and Varvarigou and Durrant's discussion framework for choral conducting (2011).
\end{abstract}

Keywords: choral conductor, choral leadership, higher education, mixed methods

Sitering av dette kapitlet: Jansson, D. \& Balsnes, A. H. (2021). Dilemmaer i skandinavisk korlederutdanning. I E. Angelo, J. Knigge, M. Sæther \& W. Waagen (Red.), Higher Education as Context for Music Pedagogy Research (s. 215-244). Cappelen Damm Akademisk. https://doi.org/10.23865/noasp.119.ch9 Lisens: CC BY-NC-ND 4.0. 
I høyere utdanning i Skandinavia foregår opplæring i korledelse på ulike nivåer og av ulikt omfang - fra dedikerte programmer til enkeltemner som del av andre musikkutdanninger (Jansson et al., 2018). Praksisfeltet er mangfoldig - korledelse er dels en generisk musikkompetanse og dels en profesjon, om enn med relativt svake profesjonskarakteristika (Molander \& Terum, 20o8). Tidligere studier antyder at det i noen grad er misforhold mellom utdanningens innhold og praksisfeltets behov (Jansson, Balsnes \& Bygdéus, 2018). Det er også mangel på kvalifiserte dirigenter, særlig utenfor de store byene. Flere av institusjonene som tilbyr korlederutdanning, gjennomfører av ulike årsaker ikke programmene hvert år. Korbevegelsens utbredelse og mangfold tilsier at utdanningstilbudet i korledelse bør være mangfoldig, både i typer og omfang, og forsyne praksisfeltet med kvalifiserte dirigenter. Riktignok bidrar korforbundene med ulike kurs, seminarer og mentorordninger som gjør det samlede tilbudet mer mangfoldig. I dette kapitlet avgrenser vi oss likevel til de akademiske utdanningstilbudene. I videreutviklingen av disse står man overfor en rekke avveininger. Formålet med dette kapitlet er å drøfte slike avveininger.

Det empiriske materialet er hentet fra tre av forfatternes tidligere gjennomførte studier med tilhørende datasett:

A) «Utdanningsstudie»: Kartlegging av skandinavisk korlederutdanning hvor dokumentanalyse og intervjuer av lærere og nyutdannede dirigenter utgjorde datagrunnlaget (Jansson, Balsnes \& Bygdéus, 2018).

B) «Kompetansestudie»: Kvantitativ spørreundersøkelse hvor 685 norske, svenske og tyske kordirigenter deltok (Jansson, Elstad \& Døving, 2019a; Jansson, Elstad \& Døving, 2019b).

C) «Karrierestudie»: Intervjustudie av tjue norske kordirigenter (Jansson \& Balsnes, 2020).

I tidligere artikler er det redegjort for tydelige funn fra disse studiene. Implikasjonene av funnene for korledelsesutdanningene er derimot ikke like entydige. Vår hypotese er at dette skyldes at avveininger man må 
gjøre i utdanningen av korledere ikke er universelt gyldige, og at det er så mange kryssende hensyn at man likevel kan ende opp med valg som ikke er utvetydig gode - altså at man står overfor ett eller flere dilemmaer. Angelo (2014) framhever betydningen av å kunne artikulere og drøfte ulike hensyn og forholdet mellom dem i sin tekst om profesjonsdilemmaer i det musikk- og kunstpedagogiske landskapet. Dilemmaene kan være av ulik art og på ulike nivåer: individuelle, kollektive, institusjonelle og politiske. De kan handle om fag og kunnskap så vel som om rolle, omdømme og identitet. Ved å rette et nytt blikk på våre tidligere studier identifiserer og drøfter vi implikasjonene for korlederutdanning. Vi stiller spørsmålene: Hvilke dilemmaer står man overfor i utforming av korlederutdanning, og hvordan belyses disse av det samlede datamaterialet? Siden dette kapitlet er basert på en nylesning av underliggende studier, er det basert på en eklektisk teorianvendelse, hvor vi benytter oss av etablerte pedagogiske kategorier så vel som av Wengers (1998) teori om læring i praksisfellesskap, Janssons (2018) kompetansemodell for dirigenter og Varvarigou og Durrants (2011) rammeverk for dirigentutdanning.

\section{Tidligere forskning}

Våre forskningsspørsmål befinner seg i krysningspunktet mellom flere tradisjoner og disipliner. I dette krysningspunktet mellom korog korledelse, kunstnerisk-pedagogisk profesjonell praksis og høyere utdanning kan vi ikke koble oss på noen klar og entydig tradisjon. Dirigenter befinner seg i en kompleks lederrolle hvor de møter en rekke konkurrerende krav (Hunt et al., 2004) som kan forstås som rollefunksjoner - kunstner, håndverker, mentor og administrator (Jansson, 2018, 2019). I utøvelsen av disse funksjonene har forskere forsøkt å forstå musikalsk ledelse fra så vidt ulike vinkler som gestikk (Fuelberth, 2003; Gumm, 2018; Manternach, 2012; Wöllner \& Auhagen, 2008; Yarbrough, 1975), relasjoner (Atik, 1994; Bonshor, 2017; Schiavio \& Høffding, 2015) og persepsjon av korklang (Daugherty, 1999; Daugherty et al., 2013; Ternström, 1994, 2003). Dirigentrollen er analysert ved bruk 
av ulike ledelsesteorier (Apfelstadt, 1997; Armstrong \& Armstrong, 1996; Goodstein, 1987; Wis, 2002). Imidlertid har inspirasjonen vært sterkere den motsatte veien: å forstå fenomenet ledelse via dirigentrollen (Bathurst \& Ladkin, 2012; Bush, 2011; Mintzberg, 1998; Sutherland \& Jelinek, 2015).

Det er en klar analogi mellom innstudering i kor og undervisning, også i profesjonelle sammenhenger. Det er derfor ikke uventet at en stor del av dirigentforskningen er gjort innenfor en pedagogisk ramme (Geisler, 2010), da med dirigenten som lærer og sangeren som elev (Brunner, 1996; Cox, 1989; Dunn, 1997; Floyd \& Bradley, 2006; Grimland, 2005; Yarbrough, 1975; Yarbrough \& Madsen, 1998). Færre har befattet seg med forskning om utdanning av dirigenter (Durrant, 1994, 1998; Silvey \& Major, 2014; Vallo, 1990). Varvarigou og Durrant (2011) har spesifikt utviklet et rammeverk for å diskutere læreplaner for dirigentutdanning, basert på seks elementer: elevforutsetninger, lærerforutsetninger, kortype og repertoar, læringsprosess, læringsutbytte og sosiokulturell kontekst.

Foreliggende kapittel er posisjonert i krysningspunktet mellom flere perspektiver og tradisjoner. Vårt bidrag er å gi en helhetlig forståelse av nøkkelspørsmål som korlederutdanning står overfor - i forbindelsen mellom utdanning og praksis, mellom musisering og ledelse og mellom pedagogikk og kunst.

\section{Teoretiske perspektiver}

Ordet korlederutdanning har tre ledd som til dels har distinkte begreper og forskningstradisjoner. Det kan undersøkes fra ulike synsvinkler som i sin tur trekker på ulike teoretiske tilganger. Kor som læringsarena kan betraktes både fra et musikkognitivt synspunkt og som praksisfelleskap. Ledelse av kor kan betraktes både som en variant av ensemblemusisering og som et organisasjons- og ledelsesdomene. Korledelse kan også betraktes med profesjonsteoretiske perspektiver. Høyere utdanning er ytterligere et fagområde, med både kulturpolitiske, økonomiske og pedagogiske innfallsvinkler. Alle disse fagperspektivene på korlederutdanning tilbyr bestemte begrepsapparater og teorier. 
Det kan diskuteres om korledelse i det hele tatt er en profesjon. Ifølge Molander og Terum (2008) handler profesjon om en type yrkesmessig organisering av arbeid. Personer med spesifikke utdanninger gis rett til autonomt å utføre visse arbeidsoppgaver, og det er knyttet normative forventninger til dem. Denne framstillingen er imidlertid en idealtype, og ulike yrker befinner seg på et kontinuum med mer eller mindre sterke profesjonskarakteristika. Det finnes ingen autorisasjon av dirigenter, og «hvem som helst» uten utdanning kan få jobb som kordirigent - i noen grad til forskjell fra kantorer og musikklærere. Profesjonsutdanninger har som regel et sentreringspunkt i form av et profesjonsfag (Angelo, 2014). Her skiller dirigentrollen seg ut ved at faget korledelse er et slags «superfag» hvor en rekke ulike fag inngår, og disse kan kombineres på mange ulike måter. Profesjoner er normalt heteroteliske (Grimen, 2008), mens korledelse har klare islett av eksistensiell mening - for sin egen skyld. Samtidig er korledelse også kjennetegnet av dedikerte utdanninger, egne organisasjoner, et visst faglig fellesskap - og er i noen grad drevet av kall (Angelo, 2014). I sum framstår derfor korledelse som en «løs» profesjon med varierende karakteristika og kan bedre forstås som et praksisfelleskap med ulike former for deltakelse (Lave \& Wenger, 1991).

De underliggende studiene for dette kapitlet har tatt både et innholdsmessig og et dynamisk perspektiv på læring. For å fange det dynamiske kompetanseutvikling over tid - har vi i utstrakt grad benyttet Etienne Wengers (1998) konsept læring i praksisfellesskap (Gherardi \& Nicolini, 2002; Korthagen, 2010; Ng \& Tan, 2009; Omidvar \& Kislov, 2014). Hans læringsteori, som er basert på praksis og læringsbaner, egner seg godt til å studere korlederes livslange læring og utvikling. Vi benytter også Janssons (2018) kompetansemodell for kordirigenter, bestående av ulike elementer fordelt på tre ulike mestringstyper: musikalsk-teknisk, situasjonsmessig-relasjonelt og eksistensielt. Kompetansemodellen dekker det innholdsmessige aspektet ved dirigentens mestring. Disse to teoriene tjener som bakgrunn for dette kapitlet, men understøtter forskningsspørsmålet bare indirekte.

Varvarigou og Durrant (2011) har foreslått et rammeverk for diskusjon av dirigentutdanning. Hovedkategoriene i denne modellen er vist i figur 1. 
Sosio-kulturelle kontekster og læringskontekst

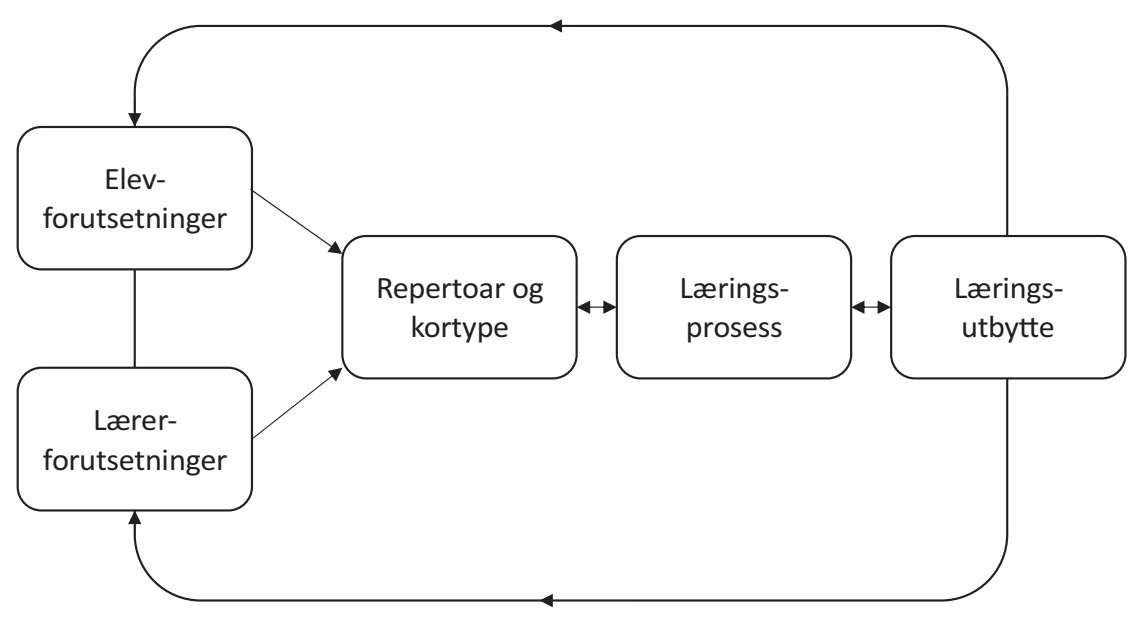

Figur 1 Rammeverk for diskusjon av dirigentutdanning (basert på Varvarigou \& Durrant, 2011)

Modellen har mange fellestrekk med mer generelle didaktiske kategorier (Bjørndal \& Lieberg, 1978), slik Hanken og Johansen (2013) presenterer dem. De skiller mellom rammefaktorer, elevforutsetninger og lærerforutsetninger, mål, innhold, metode og vurdering. For tre av kategoriene er de to modellene identiske. Det gjelder læringsmål, elevforutsetninger og lærerforutsetninger. Modellene skiller seg på et par punkter. Hanken og Johansens kategori «innhold» er for dirigentutdanning knyttet opp mot de to spesifikke hovedelementene kortype og repertoar, hvilket impliserer at alt øvrig innhold underordnes disse. Imidlertid er «metode» i Varvarigous og Durrants modell kalt «prosess» og må dermed oppfattes som en videre kategori. Rammefaktorkategorien hos dem inkluderer eksplisitt sosiokulturell kontekst. Noe forenklet kan vi si at kategoriene som Hanken og Johansen presenterer, har et didaktisk blikk, mens Varvarigou og Durrant inntar et mer overordnet pedagogisk blikk.

Felles for begge modellene er at legitimering av utdanningen er håndtert som et bakgrunnstema. Det er ikke eksplisitt berørt av Varvarigou og Durrant ut over eventuelt å være en del av den sosiokulturelle konteksten. Hos Hanken og Johansen er legitimering innbakt i målkategorien som formål. Legitimering er imidlertid implisitt gitt av et annet begrepsapparat en pedagogisk grunnposisjon - hvor Hanken og Johansen opererer med 
fem: elevsentrisk, dannelsessentrisk, målsentrisk, fagsentrisk og kritisk. I noen av disse kan vi gjenfinne visse legitimeringer av dirigentrollen og dirigentutdanningen. For eksempel har dirigentutdanningen fra starten vært basert på en kombinasjon av fagsentrisme og dannelse. Fordi dirigentrollen er et slags superfag som trekker på en rekke delfag, blir sammenhengene mellom disse viktige (Jansson, 2018; Durrant, 2003). I tillegg har den historiske verkkanon og store dirigenters eierskap til faget gjort dirigentutdanning til et dannelsesprosjekt (Schonberg, 1967). Med større bredde i kortype og repertoar utfordres denne fagdannelsesposisjonen og gir rom for andre legitimeringer.

Frede V. Nielsen (1998) gjør et skille mellom undervisningsfaget og basisfaget musikk, og for basisfaget skiller han mellom tre orienteringer: vitenskap, håndverk- og hverdagskunnskap og kunst. Denne inndelingen er problematisk for dirigentrollen fordi utøvelsen forutsetter hele spektret i de ulike funksjonene som kunstner, håndverker, mentor og administrator (Jansson, 2018). Korlederfaget går derfor også tydelig utenfor det rent musikkfaglige, i og med at det også omfatter relasjonelle og organisasjonsmessige ferdigheter. Dette bidrar til forventningspress mot fag og studieplaner i korledelse.

I utgangspunktet kan vi ikke forvente at de dilemmaene vi identifiserer, faller entydig og fullstendig inn i etablerte kategorier. Selv om det finnes valg som må gjøres innen de pedagogiske kategoriene, betyr ikke det at alle er forbundet med motsetninger eller spenninger. Videre synes det åpenbart at et dilemma godt kan berøre flere kategorier. Varvarigou og Durrants modell og Hanken og Johansens pedagogiske grunnposisjoner utgjør det teoretiske startpunktet for analysen. Disse tjener som en sjekkliste for empiriske observasjoner, uten at dilemmaene tvinges inn i kategoriene. Vi har i stedet vært forberedt på at dilemmaene antar sin egen struktur.

\section{Metode}

I løpet av 2017 foretok forfatterne sammen med en kollega en kartlegging av skandinaviske korlederutdanninger (Jansson, Balsnes \& Bygdéus, 2018). Målet med undersøkelsen var å kartlegge hvilke utdanninger som fantes, 
hvilken profil de hadde, hva slags ensembler de utdannet for, samt hvor mange studenter utdanningene på det tidspunktet omfattet. Fem av institusjonene ble valgt ut for nærmere undersøkelser - alle var lokalisert i store byer og tilbød masterprogram i korledelse. Åtte dirigentlærere og tolv dirigenter som var uteksaminert i løpet av de siste tre årene, ble intervjuet, noen individuelt og andre i grupper. Materialet fra denne studien refereres til som datasett $\mathrm{A}$ (i teksten merket ${ }^{\mathrm{A}}$ ), og undersøkelsen refereres til som «utdanningsstudien».

Jansson og kollegaer gjennomførte også i 2017 en kvantitativ undersøkelse blant 294 norske kordirigenter som tok utgangspunkt i de ulike elementene i Janssons (2018) kompetansemodell (Jansson, Elstad \& Døving, 2019a). Målet var å finne ut hvordan dirigenter vurderer sin egen kompetanse når det gjelder viktighet av de ulike elementene og eget nivå, samt hvordan utdanning og praksis har bidratt. Utvalget ble deretter utvidet med 344 svenske og 47 berlinbaserte respondenter. Utvidelsen gjorde det mulig å undersøke om det var variasjoner mellom land, og å foreta mer detaljerte statistiske analyser (Jansson, Elstad \& Døving, 2019b). Denne undersøkelsen refereres til som «kompetanseundersøkelsen» og materialet kalles datasett ${ }^{\mathrm{B}}$.

I kompetanseundersøkelsen kunne deltakerne krysse av for om de kunne tenke seg å bli kontaktet for oppfølgingsintervju. 156 av de norske respondentene ( 52 prosent) krysset av positivt, og cirka en firedel henvendte seg aktivt per epost. Tjue av disse ble valgt ut med henblikk på maksimal variasjon med hensyn til kjønn, alder, bakgrunn, utdanning og type kor, og de ble intervjuet individuelt i løpet av 2018. Målet var å undersøke fellestrekk og identifisere mønstre for variasjon i dirigentenes utviklingsbaner. De ble spurt om nåværende arbeidssituasjon, utdanning, praksis og syn på dirigentrollen (Jansson \& Balsnes, 2020). Dette materialet refereres til som datasett ${ }^{\mathrm{C}}$, og selve undersøkelsen refereres til som «karrierestudien». To av studiene behandlet sporbar personinformasjon og er godkjent av NSD, og øvrige prosedyrer for forskningsetikk er fulgt.

Studiene vi tar et nytt blikk på i dette kapitlet, er basert både på kvalitative og kvantitative metoder. Dermed bygger det uvegerlig på det vi kan kalle en blandet metode, hvilket også bør være en styrke ved at en 
kombinasjon forventes å gi bedre svar enn hver enkelt metode alene (Cresswell \& Piano Clark, 2011). Utfordringen med blandet metode er en forsterket motsetning mellom deduksjon og induksjon. Vår løsning er en abduktiv logikk som innebærer en dialog mellom eksisterende kunnskap og nye forestillinger om fenomenet vi undersøker (Rennie, 2012; Timmermans \& Tavory, 2012). Vi baserer oss på en praksisorientert abduktiv metode som gir rom for både logikk og intuisjon, forforståelse så vel som tilsidesettelse av antakelser («bracketing») (Raelin, 2020). Abduktiv metode er mer egnet til å utvikle teori enn til å teste teori. Det betyr at når vi trekker inn kvantitative funn i en abduktiv analyse (hvilket er uvanlig), fungerer disse som kvalitative elementer i resonnementene.

Analysen ble gjennomført som to parallelle prosesser - en logiskdeduktiv og en kreativ-induktiv. Det foregikk dermed en dialog mellom stadig mer oppdatert innsikt og ideer til ytterligere forbedringer. Hver av prosessene hadde distinkte trinn, selv om disse ikke foregikk rent sekvensielt.

\section{(A) Logisk-deduktiv prosess}

(A1) Vi tok utgangspunkt i utdanningsstudien som dekker hva som finnes av utdanning, og innretningen av disse. Variasjonene som forekom, avspeiler valg (ofte implisitte), hvorav de fleste er på institusjonsnivå.

(A2) Vi undersøkte hva de to andre studiene forteller om variasjonen og valgene, herunder om utdanningene treffer og er mer eller mindre relevante for ulike grupper og situasjoner.

(A3) Karrierestudien dekker hvordan en dirigentpraksis faktisk forløper. Med utgangspunkt i denne undersøkte vi - via de to andre studiene i hvilken grad behovene i yrkespraksis dekkes for ulike aspekter av kompetansemodellen.

Denne prosessen avdekket både funn som bekreftes av flere studier, og funn hvor det finnes tydelige moteksempler. Moteksempler er tegn på at det finnes spenninger mellom ulike hensyn. Den kreativ-induktive prosessen søkte å avdekke strukturen på disse spenningene. 


\section{(B) Kreativ-induktiv prosess}

(B1) Vi identifiserte og begrepsfestet hvilke spenninger som forekom.

(B2) Vi undersøkte om spenningene er reelle, altså om det faktisk finnes motstridende hensyn i dataene som kan betraktes som dilemmaer.

(B3) Vi undersøkte om dilemmaene er distinkte, det vil si at de ikke er så avhengige at de i praksis er det samme dilemmaet. Færre dilemmaer kan gi mer distinkte kategorier, men risiko for å miste detaljer. For mange dilemmaer gir opphav til for mye avhengighet mellom dem.

(B4) Vi vurderte settet av dilemmaer som helhet med tanke på sammenheng og konsistens.

Prosessen er en utpreget skriveprosess. Det betyr at den dokumenteres i form av de ferdig utviklede resonnementene. Siden resultatene innebærer en nylesning av tre underliggende studier, har vi valgt å presentere en kort resultatdel som kun dekker tilleggsmomenter. I diskusjonsdelen, derimot, gjør vi en grundigere tilbakekobling til de tidligere resultatene. Vi har valgt å referere til våre egne datasett og studier i form av sluttnoter for å skille dem tydelig fra andre referanser.

\section{Resultater}

I nylesningen av de underliggende studiene observerer vi beslektede funn fra flere vinkler. For eksempel: Hva innebærer dedikerte dirigeringsprogrammer kontra enkeltemner som del av et annet musikkprogram? Her sier kompetansestudien at det i hovedsak er dedikerte programmer som er utslagsgivende for selvopplevd kompetanse. Samtidig viser utdanningsstudien at det er vanskelig å skille klart mellom innholdet i de to programtypene. Dette leder til at spenningsaksen mellom programtypene handler om eksponering for dirigeringsfaget - altså omfang. Et annet eksempel er at utdanningsstudien viser et sterkt ønske fra dirigeringslærere om mer ensembletid. Samtidig forteller karrierestudien at tidligere studenter savner spesifikk undervisning i relasjonelle ferdigheter, og den kvantitative studien fant at hørelære som skolefag verdsettes i 
$ø$ kende grad med erfaring. I dette krysningspunktet mellom de tre studiene framtrer dermed emnestruktur som en tydelig spenningsakse. Et tredje eksempel er enkelte dirigenters opplevelse (karrierestudien) av opplæringen i dirigeringsteknikk som en tvangstrøye med én lærer, men mer frigjort med en annen. Noen lærere legger stor vekt på et individualisert uttrykk, mens enkeltemner i dirigering som oftest ikke gir rom for annet enn å overbringe konvensjoner. Her framtrer utdanningens estetiske orientering som en viktig spenningsakse.

Ved gjennomarbeiding av de tre datasettene identifiserte vi sju slike spenningsakser, vist i figur 2. I første omgang ble disse identifisert på selvstendig grunnlag. Vi undersøkte deretter i hvilken grad temaene er distinkte, overlapper hverandre eller står i et bestemt forhold til hverandre. Er det slik at et bestemt valg for én spenningsakse styrer valgmulighetene for andre? Vi observerte at de delvis avhenger av hverandre, og at avhengigheten opptrer i form av ulike posisjoner på en hvorfor-hvordan-linje. Hvorfor brukes her som en betegnelse på det som ligger bak utdanningen - det dekker dermed hvem utdanningen er for, og det gir føringer for hva den inneholder. Hvordan brukes som betegnelse på didaktiske avveininger, som i sin tur peker tilbake på hva utdanningen inneholder. På bakgrunn av denne strukturen utviklet vi de sju begrepene som spenner ut hvorfor-hvordan-linjen for korlederutdanning.

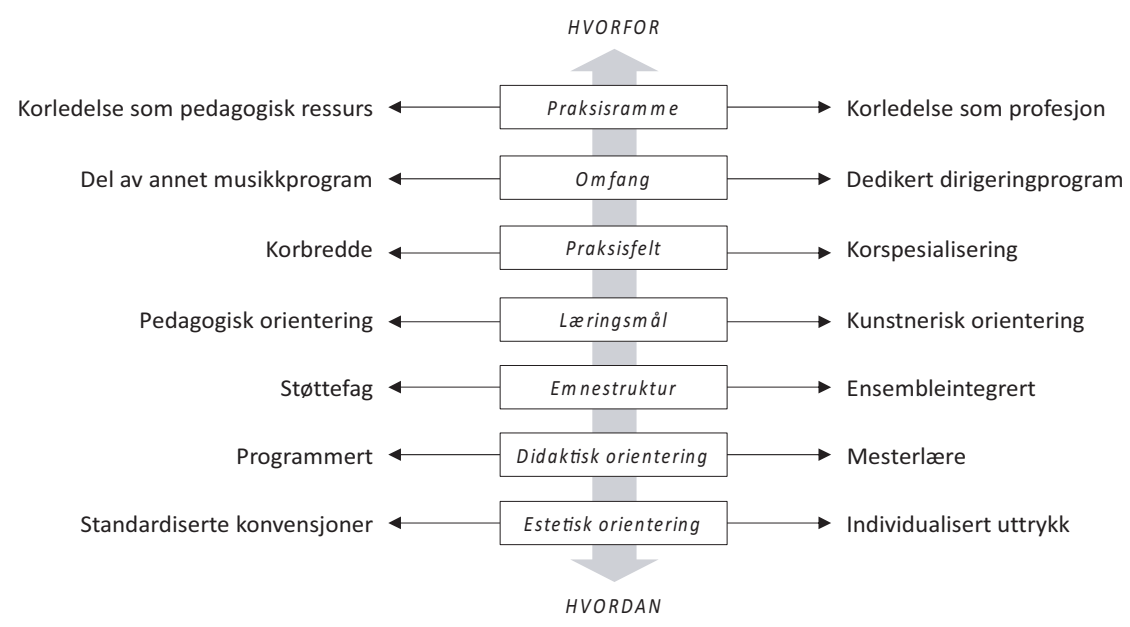

Figur 2 Spenningsakser i utforming av korlederutdanning 
I diskusjonsdelen tar vi for oss hver av de sju spenningsaksene og ser dem i lys av de underliggende dataene. Her følger en kort definisjonsmessig forklaring:

- Praksisramme handler om hvorvidt utdanningen skal lede til korledelse som en distinkt profesjon, eller om den betraktes som et verktøy i andre praksiser.

- Omfang dreier seg om hvorvidt dirigering er selve «hovedinstrumentet», eller om korledelse utgjør del av et annet utøvende eller pedagogisk musikkprogram.

- Praksisfelt er spørsmålet om hvorvidt utdanning skjer med henblikk på en bestemt kor- og repertoartype, eller om den legger an til et bredt korfelt med ulike ensembletyper.

- Loeringsmål handler om hvorvidt korledelse betraktes som en kunstutdanning eller som en pedagogisk utdanning.

- Emnestruktur er spørsmålet om hvordan alle de ulike kompetanseelementene i dirigentrollen dekkes - i integrerte ensemblesituasjoner eller som enkeltstående emner.

- Didaktisk orientering handler om i hvilken grad undervisningen følger den lange tradisjonen innen kunsten - mesterlære - eller om den har en mer standardisert form.

- Estetisk orientering avspeiler hvorvidt utdanningen tar sikte på å overbringe dirigeringsmessige konvensjoner, eller om den framelsker individualiserte former og uttrykk.

\section{Diskusjon}

\section{Praksisramme - ressurs eller profesjon}

Ensembleledelse kan betraktes som en tilleggsressurs ut over det å være spillende og syngende musiker. Dirigentfunksjonen som en distinkt rolle fant formen vi kjenner i dag, tidlig i romantikken (Durrant, 2003; Lebrecht, 1992). Likevel er og forblir dirigenten et ensemblemedlem, selv om funksjonen er profesjonalisert. Korledelsesfaget befinner seg dermed i et kontinuum mellom vokalgruppemedlemmet som tidvis inntar en lederrolle, og den ikoniske figuren som kommer sist inn på scenen og 
mottar applaus på vegne av ensemblet. I noen sammenhenger inntar korledelsesfaget en understøttende posisjon i en annen profesjon. Både musikklærer- og kirkemusikerprofesjonen har korledelse som et verktøy eller en ressurs.

Denne spenningsaksen handler både om legitimering av faget og om den sosiokulturelle konteksten korlivet befinner seg i. Organisering av korfeltet varierer mellom ulike nasjonale kulturer og historier. I England og Sverige er kortradisjonen nært knyttet til kirken og kirkemusikerfunksjonen (Jansson, Balsnes \& Bygdéus, 2018; Varvarigou \& Durrant, 2011). I USA er korvirksomhet særlig knyttet til videregående skoler og universiteter (Gonzo, 1973; Grant \& Norris, 1998; Hylton, 1983; Vallo, 1990). Det norske korfeltet er mer blandet, selv om både kirke og skole er viktige arenaer også her. I hvilken grad korledelse er en profesjon på egne premisser, eller et innslag i en annen profesjon, påvirker forventninger til kompetansebredde og -nivå. Jo mer distinkt profesjonen er, desto mer selvstendig blir rollen, og desto bredere blir kompetansekravene, ved at organisasjonsmessige og administrative aspekter blir tydeligere. Det vil også innebære et større innslag av frilansere og selvstendig næringsdrivende. Vår hypotese er at dette er tydeligere i Skandinavia enn i USA og Storbritannia og tydeligere i Norge enn i Sverige. Et aspekt ved utdanning innen korledelse som profesjon som særlig gjelder de dedikerte korlederutdanningsprogrammene, er at uteksaminerte studenter rapporterer at de hadde ønsket å lære mer om kordrift (rekruttering, prøvesang, søknadsskriving med mer) og entreprenørskap som en forberedelse til en frilanstilværelse.

Kordirigent er et yrke utøverne forblir lenge i - medianerfaringen er 22 år. Samtidig er kordirigent som oftest et deltidsyrke. Tre av ti norske dirigenter har kordirigering som en vesentlig del av sitt (betalte) årsverk (20-70 prosent), mens bare en av ti kan betraktes som fulltidsdirigenter. ${ }^{\mathrm{B}}$ Intervjuene med både nyutdannede og etablere dirigenter vitner om lappverk av stillinger som i de fleste tilfeller omfatter utøvende virksomhet og undervisning i tillegg til kordirigentjobber A, C-en karrieretype som av Kalsnes (2014) betegnes som «nomade». I karrierestudien er det også eksempler på dirigenter som har ikke-musikkrelaterte jobber ved siden av korvirksomheten. Et ressursperspektiv på korledelse innebærer 
at kor er et middel for noe annet, fra musikkteori og gehørtrening til sosial aktivisering eller menighetssang. Dette perspektivet kan gi andre faglige prioriteringer enn om utdanningen forbereder til en rendyrket dirigentprofil. Deler av utdanningstilbudet innen korledelse på universitets- og høyskolenivå i Skandinavia har et begrenset omfang som i seg selv innebærer et ressursperspektiv på korledelsesfaget. Små enkeltemner i dirigering blir nødvendigvis en komponent i noe annet. De vil derfor måtte bli døråpnere til en eller annen praksis, uten at de er rene profesjonsutdanninger. I noen grad løses dilemmaet ved at lange utdanninger, for eksempel et bachelorprogram i dirigering, legger opp til å forme en full dirigentprofil. Et masterprogram muliggjør en full konvertering til (eller bekreftelse på) en dirigentprofil.

\section{Omfang - dedikerte dirigeringsprogrammer eller bredere programmer}

Det finnes både bachelor- og masterprogrammer i kordirigering så vel som årsstudier og mindre enheter. Kompetanseundersøkelsen viser at de aller fleste norske dirigenter har ett eller flere dirigeringsemner på høyskolenivå. 19 prosent av respondentene oppgir at de har en bachelorgrad i korledelse eller sterkt innslag av korledelse, og 16 prosent har mastergrad eller hovedfag i korledelse. Når det gjelder musikkutdanning av alle typer, har 35 prosent bachelorgrad og 38 prosent mastergrad. Det betyr altså at et mindretall ikke har en akademisk grad i musikk.

Utdanning har betydning for kompetanse, men bildet er ikke entydig. Dersom vi bare ser på utdanning kontra ikke utdanning, er utdanning positivt for dirigenters selvopplevde kompetanse, og mastergrad betyr mer enn bachelorgrad. ${ }^{\mathrm{B}}$ Men når vi trekker inn andre faktorer, synes praksis å dominere over utdanning. De to faktorene som best forklarer variasjoner i selvopplevd kompetanse, er nivåt på dirigentens kor og antall år med erfaring. I en slik utvidet analyse betyr utdanning fortsatt noe, men vel å merke bare dedikerte dirigeringsprogrammer, og mastergrad betyr også her mer enn bachelorgrad.

Det kan være flere grunner til at generell musikkutdanning med eller uten dirigeringsemner ikke er mer avgjørende for selvopplevd 
kompetanse. Den viktigste grunnen ser ut til å være at kordirigenter former sin praksis ut fra den situasjon de finner seg i, med de ressursene de har til rådighet. Våre studier viser at formingen av en dirigentpraksis kan forstås som en «sensemaking»-prosess (Jansson \& Balsnes, 2020; Weber \& Glynn, 2006; Weick et al., 2005). Dirigenter skaper mening og identitet i en sosial og kognitiv prosess hvor de objektive kravene betyr mindre enn den handlende tilpasningen. Tilpasningen mellom egne forutsetninger og den konkrete arbeidssituasjonen understreker hvor viktig praksis er, hvor enkeltemner i dirigering kan være et tilfredsstillende grunnlag for en dirigentpraksis. Imidlertid kan det tenkes at små enkeltemner (5-10 studiepoeng) tjener mer som appetittvekkere enn som kompetansebyggere. Helgekurs og mesterklasser ser ikke ut til å gi utslag for selvopplevd kompetanse. ${ }^{C}$ Omfanget er begrenset, og positive bidrag kommer mer i form av profesjonelt fellesskap.

At dedikert dirigeringsutdanning betyr mest når det gjelder å forklare variasjoner i selvopplevd kompetanse, kan forstås ut fra mengde og dybde i eksponeringen for faget. I tillegg kan en hypotese være at dirigeringsutdanning på bachelor- og masternivå medfører en viss laugtilhørighet (Wenger, 1998) som i seg selv gir mestringstro («self-efficacy») - og nettopp mestringstro er funnet å være en viktig lederkompetanse (Machida \& Schaubroeck, 2011; van Knippenberg et al., 2004). Dirigeringsprogrammer har få plasser, noe som kan bidra ytterligere til opplevelsen av eksklusivitet. Kjernen i dilemmaet er at den typen utdanning som gir best effekt i sum gir for lav kapasitet. Samtidig er enkeltemner og kortere programmer ofte inngangsporten til dirigentyrket og avgjørende for å dekke behovet for dirigentkapasitet. Dilemmaet forekommer derfor både på institusjonsnivå og for den enkelte dirigentkandidat.

\section{Praksisfelt - bredde eller spesialisering}

Utdanningens formål vil innvirke på både innhold og metoder i undervisningen - med Varvarigou og Durrants (2011) kategorier: kortype og repertoar. De fem skandinaviske institusjonene vi undersøkte spesielt, hadde valgt ulike innfallsvinkler med hensyn til hva slags kor utdanningene retter seg mot. Lærerne på Kungliga Musikhögskolan (KMH) i 
Stockholm var særlig tydelige på at deres studenter «skal stå foran Radiokören og fikse det. Helt fra starten handler alt om dette». ${ }^{\mathrm{A}}$ Også på masterprogrammet ved Norges musikkhøgskole (NMH) i Oslo var det et uttalt mål at de uteksaminerte skal kunne jobbe med profesjonelle ensembler. På Det Jyske Musikkonservatorium i Århus ønsket man derimot å gi en bred kvalifisering for spennet fra amatørkor til profesjonelt nivå, og også på bachelorprogrammet på NMH ble det uttalt at man ønsker å gi plass til «barnekor, pensjonistkor, jazzkor». Der ble det for eksempel startet opp et videreutdanningstilbud i barnekorledelse på 15 studiepoeng i 2019. Högskolan för scen og musik (HSM) i Göteborg har inkludert barne- og ungdomskor samt musikkteater i sitt pensum på magisternivå, mens Det Jyske Musikkonservatorium, avdeling Ålborg, er dedikert til rytmisk korledelse.

En form for legitimering av utdanninger er samfunnets behov (Hanken \& Johansen, 2013). Dersom vi ser på den sosiokulturelle konteksten norske korlederutdanninger forholder seg til, og hva slags kor norske dirigenter faktisk leder, viser kompetanseundersøkelsen at sju av ti respondenter leder voksenkor, mens tre av ti leder barne- og ungdomskor. 51 prosent oppgir at de jobber med amatørkor, mens 42 prosent har avanserte amatørkor. Kun 7 prosent leder profesjonelle eller semiprofesjonelle kor. Riktignok foregår det en profesjonalisering av korfeltet (Simonsen, 2010) som legitimerer flere studieplasser med søkelys på avanserte kor. Det var likevel gjennomgående at dirigentene som ble intervjuet, uttrykte at de hadde lært for lite om amatørkorledelse i løpet av studiet: «Om man ikke får et kor på høyt nivå, har du ikke lært så mye av det du trenger», sier en av dem. ${ }^{\mathrm{C}}$ En uteksaminert student snakker om «barnekorsjokket» vedkommende fikk da han etter endt utdanning skulle dirigere barnekor. ${ }^{A}$ Dette kan tyde på at det finnes kompetanser som er spesifikke for ulike kortyper.

Imidlertid viser kompetanseundersøkelsen kun moderate til marginale ulikheter i syn på egen kompetanse i dirigentpopulasjonen, på tross av den brede variasjonen i type kor. For eksempel er det kun nivået på korene den enkelte dirigent leder som spiller inn på variasjoner i synet på egen kompetanse når det gjelder innøvingsmetodikk. ${ }^{\mathrm{B}}$ Det tyder på at det finnes et sett med kordirigentkompetanser som er mer eller mindre 
universelle, noe som gjør at det er mindre relevant hva slags kornivå man legger opp til i studiet. Studentene vil uansett lære seg de grunnleggende kompetansene, og de må selv overføre disse til de korene de ender opp med å dirigere etter endt studium.

En annen faktor er at selv om et studium retter seg mot en bred vifte av kor, kan utdanningen i praksis ha slagside mot avanserte kor, fordi øvingskor ofte består av medstudenter og innleide sangere, noe som ikke gjenspeiler sangerpopulasjonen i samfunnet. Et tiltak for å motvirke dette er praksis i ulike kor. For eksempel er det obligatorisk å lede kor ved siden av studiet på bachelorstudiet ved NMH. På magisterprogrammet ved HSM har alle studentene egen korpraksis i tillegg til regelmessig hospitering $\mathrm{i}$ andre kor.

\section{Læringsmål - kunstnerisk eller pedagogisk orientering}

Korledelse befinner seg i grenselandet mellom kunstnerskap og pedagogisk praksis. De tre aspektene ved basisfaget musikk - vitenskap, håndverk og kunst (Nielsen, 1998) - er tett sammenvevd i en mangefasettert dirigentrolle. Spenningen mellom kunst og pedagogikk hviler i noen grad på legitimering av utdanningen. Den gryende profesjonaliseringen av korfeltet i Norge (Simonsen, 2010) innebærer at flere dirigenter og kor holder et nivå på linje med det profesjonelle kunstlivet for øvrig. Antall og bredde av avanserte amatørkor har dessuten økt jevnt i løpet av de siste tiårene. Likevel er korfeltet som helhet en utpreget blandingsarena hvor dirigenten ofte er profesjonell og sangerne amatører, med sterkt innslag av lærer-elev-relasjoner. Innstuderingssituasjonen er svært lik andre musikkpedagogiske situasjoner, og dirigentrollen kan være vanskelig å skille fra lærerrollen (Price \& Byo, 2002). Korlederrollen er også historisk nært knyttet til kantorrollen, hvis kjerneoppgave er å instruere og tilrettelegge menighetens sang.

Dirigentrollen forutsetter både en musikalsk idé og et besluttsomt lederskap. En slik kunstnerisk vilje er en eksistensiell grunnkompetanse i utøvelsen av korledelse. Den er så sentral at kordirigenters vurdering av eget kompetansenivå når det gjelder kunstnerisk vilje, korrelerer sterkt 
med vurderingen av dens viktighet, sterkere enn for øvrige kompetanseelementer som befinner seg på det musikalsk-tekniske og situasjonsmessig-relasjonelle nivåt. ${ }^{\mathrm{B}}$ Det er verdt å merke seg at dette fenomenet ikke varierer med dirigentens utdanning eller nivået på koret. For dirigenten kommer kunstnerskap og ledelse sammen i en og samme rolle. For vellykkede kunstledere kombineres en tydelig kunstneridentitet med lederidentitet (Elstad \& Jansson, 2020). På dette punktet synes dirigenten å være nærmere kunstneren enn læreren.

De store skandinaviske dirigentutdanningsinstitusjonene dekker både et internasjonalt ambisjonsnivå og varierte nasjonale behov. Til tross for stort spenn mellom korkunst på internasjonalt nivå og korsang som hyggeaktivitet i lokalmiljøet må korfeltet betraktes som en sammenhengende arena for dirigenten, uten vanntette skott mellom deler av praksisfeltet. Dette felleskapet betraktes av en dirigentlærer dels som et problem, ved at korsang som folkebevegelse gjør at korkunst ikke gis nok kulturpolitisk tyngde:

Det er vanskelig for profesjonelle kor å bli tatt på alvor ... på grunn av fenomenet at mange synger i kor. Beslutningstakerne synger selv i kor. Det er viktig å kunne odle korkunsten som høytstående kunstnerisk aktivitet også - ikke bare med argumenter om at det er bra og nyttig å synge i kor. ${ }^{\mathrm{A}}$

Samtidig er ikke et sammenhengende praksisfelt uten videre et problem; en stadig dyktigere dirigentprofesjon bidrar til å løfte hele korfeltet. En av konsekvensene er at samvirket mellom amatørmusikklivet og det profesjonelle musikklivet forsterkes i lokalmiljøene.

Det er imidlertid et problem i spenningsaksen mellom kunstnerisk og pedagogisk orientering at mellommenneskelige og ledelsesmessige ferdigheter uansett er gjennomgående dårlig dekket i dirigentutdanningene. I vårt materiale er det mange vitnesbyrd om at dirigenter opplever å komme ut av utdanningene med mangelfull relasjonell kompetanse. Dette forhindrer imidlertid ikke at dirigentlærerne er opptatt av det mellommenneskelige og betrakter seg som tjenere for musikken og ensemblet, og et slikt «tjenende lederskap» («servant leadership») er tidligere teoretisert i korsammenheng (Wis, 2002). Men selv om grunnholdningen vektlegges, omfatter det ikke uten videre systematiske og eksplisitte 
programelementer hvor studentene bruker tid på relasjonell teori og praksis. En lærer uttaler: «Det ledelsesmessige aspektet, det som handler om det sosiale, konfliktløsning, styrearbeid, det har vi ikke nok av i studieplanen. Vi har teoretisk pedagogikk, men hvordan man håndterer konflikter har vi ikke nok styr på». ${ }^{A}$ Dilemmaet er først og fremst et problem med prioritering av temaer innenfor begrenset undervisningstid. Dirigentrollen er en lederrolle som ville fortjent omfattende utdanning innen generelle team- og ledelsesfaglige spørsmål. Samtidig er rollen spekket med musikkfaglige ferdigheter som må utvikles - også ut over det som forventes av ensemblemedlemmer. I praksis er det ikke mulig å betjene alle disse behovene fullt ut.

Spørsmålet om kunstnerisk kontra pedagogisk orientering av dirigentutdanning henger i noen grad sammen med dedikert dirigeringsprogram kontra allmenne musikkprogrammer hvor dirigeringsemner inngår. Dilemmaet kan tilsynelatende løses ved at studenter selv velger sin dirigentutdanning. Men det er ikke tilfredsstillende, all den stund dirigenten som kunstner ikke kan tre ut av lederrollen eller neglisjere sin pedagogiske funksjon. Relasjonell kompetanse forblir uansett en grunnstein, og denne kompetansen ser ikke ut til å være godt nok ivaretatt i utdanningene.

\section{Emnestruktur - ensembletid eller støttefag}

Jo nærmere vi kommer «hvordan»-siden i modellen, desto mer nærmer vi oss didaktiske avveininger knyttet til innhold og metode. De tre lagene i kompetansemodellen (Jansson, 2018) utgjør ulike forutsetninger for ensemblesituasjonen. Det eksistensielle grunnlaget, som omfatter blant annet hengivenhet, autoritet og vilje, er egenskaper og tilbøyeligheter dirigenter bringer med seg inn i selve ensemblesituasjonen. Disse kan i liten grad tillæres, men kan dyrkes og modnes, og de kommer til uttrykk i møtet med koret. De musikalsk-tekniske kompetansene, som omfatter blant annet repertoarkunnskap, partituranalyse, hørelære, vokalteknikk og gestikk, kan i all hovedsak læres utenfor ensemblesituasjonen, og kanskje - slik en lærer uttrykker det - med fordel: «Det er også bedre, fordi det er færre krefter i spill i laboratoriet. Laboratoriesituasjonen kan også 
lære studentene til å bli trygge på at det man gjør virker, holde fast og repetere ting man mener fungerer». ${ }^{\mathrm{A}}$ Musikalsk-tekniske kompetanser har også andre anvendelser enn i dirigentrollen. Innlæring av gestiske ferdigheter har for øvrig noen begrensninger utenfor ensemblesituasjonen. Selv om ferdighetene er tekniske i sin karakter, og selv om bevegelsene kan læres og trenes alene eller med veileder, vil dirigenten først erfare deres virkning i møte med et syngende ensemble. Det er da de vil kunne tilpasses og raffineres til å understøtte det ønskede lydbildet.

Situasjons- og relasjonskompetansene er definert ut fra et møte mellom dirigent og sangere. Men også disse har analytiske aspekter hvor det er mulig å bygge en grunnforståelse før møtet med ensemblet. Dette gjelder for eksempel mentorskap - evnen til å veilede og gi tilbakemelding. Det gjelder også planlegging av innstuderingsprosessen og tilegnelse av en variert verktøykasse for de konkrete innstuderingsgrepene, herunder partiturspill, demonstrasjon, ulike didaktiske tilnærminger for ulike type partiturer og liknende. Den mest gjennomgripende situasjons- og relasjonskompetansen er balanseringen mellom det å kontrollere og å slippe fri. Denne kompetansen må læres i virkelige ensemblesituasjoner, noe en av dirigentlærerne setter ord på: «Alt som handler om energistrømmer mellom dirigent og ensemble, må læres i selve situasjonen. Det handler om mental tilstedeværelse, kontakt, pust og situasjonsbedømmelse. Det handler også om å lytte og forstå hva som skjer». ${ }^{A}$ Denne erkjennelsen gjør at de intervjuede dirigentlærerne ønsker seg mer ensembletid i sine programmer. Samtidig er presset for å få nok tid til støtteemner stort, både fordi de er nyttige, og fordi det kan være bestemt av overordnede programkrav. Ensembletid er kostbart og begrenses derfor også av budsjettrammer. Utdanningsinstitusjonene har ulike modeller for ensembletid: betalte sangere, dirigentstudentensemble og studentenes egne ensembler. Pensumrepertoaret avgjør hvor effektive de ulike ensembletypene vil være. En løsning er å legge inn som obligatorisk krav at studentene skal dirigere kor utenom studiet, enten som praksiskor organisert av institusjonen, eller som en ordinær jobb. En av de uteksaminerte studentene gir tydelig uttrykk for betydningen av dette: «Det viktigste var at de ga meg et praksiskor». ${ }^{A}$ Dette kan kompensere for særlig de dedikerte utdanningenes slagside mot avanserte kor. 
Et fag som skiller seg ut i undersøkelsen av dirigentkompetanser, er hørelære. ${ }^{\mathrm{B}}$ Kompetansestudien viste at dirigenter setter mer og mer pris på sin opprinnelige hørelæreundervisning jo mer tid som er gått siden utdanningen. Det tyder på at hørelærekompetanse er egnet som støttefag, og den erfaringen med gehør og feilretting dirigenter tilegner seg i praksis, er av en annen karakter enn det grunnlaget som ble lagt i hørelæretimene.

Alle relevante støttefag gir samlet et krav på studietid som ikke er tilgjengelig. Dirigeringslærere ønsker å prioritere ensembletid samtidig som de innser betydningen av støttefagene. Det som letter presset, er om innhold og aktivitet i støttefag bygger opp under samme prosjekt. Åpenbare eksempler er når ett og samme musikalske prosjekt behandles både via musikkhistorie, partituranalyse, hørelære, dirigeringsteknikk og innstuderingsmetodikk. Imidlertid innebærer dette noen utfordringer. Ulike fag har sin iboende kunnskapsstruktur (Hanken \& Johansen, 2013) som kan tale for en rendyrking. I et integrerende ensembleprosjekt blir enkeltfagene nødvendigvis underordnet helheten. Dermed er man i noen grad tilbake i det opprinnelige dilemmaet.

\section{Didaktisk orientering - programmert eller mesterlære}

Denne spenningsaksen handler om pedagogiske grunnposisjoner. Er utdanningen dannelsessentrert mesterlære, eller følger den en fagsentrert struktur? Ut over mål for studiene finnes det sjelden mer detaljerte emnebeskrivelser - bortsett fra den som gjelder musikalsk-tekniske støtteemner, for eksempel gehørundervisning. Undervisning i det vi kan kalle kordidaktikk eller kormetodikk (som tilhører kategorien situasjonsrelasjonell kompetanse), foregår ofte som mesterlære (Nielsen \& Kvale, 1999), særlig på de dedikerte programmene. En av dirigentlærerne beskriver opplegget slik når han blir spurt om hvilke emner som inngår i studieplanen:

De fire studentene følger samme opplegg, uavhengig av når de er tatt inn. Det er derfor ingen progresjon i studieplanen - progresjonen er noe som foregår $i$ kandidaten. Opplegget er mester/svenn-orientert og dermed svært eklektisk. Det er kun to hovedlærere. Disse har også utformet opplegget. ${ }^{\mathrm{A}}$ 
Det er særlig to årsaker til denne tradisjonen. For det første blir det ofte en-til-en-undervisning fordi det er så få studenter, særlig på masternivå, men også på dedikerte bachelorprogrammer. For det andre er faget tydelig preget av praksisbaserte idealer. Dirigenter har «eid» faget siden det ble unnfanget, og det er framstående dirigenter som underviser på universitets- og høgskolenivå. ${ }^{A}$ Kunnskap er internalisert og taus (Polyani, 20oo) og dermed naturlig overførbar via mesterlære. Mesterlære ser ut til å ha en tendens til å rette søkelyset mot de unike sidene ved dirigering, for eksempel gestikk, mer enn generell pedagogikk eller ledelse. Dette kan bidra til at utdanningene ikke alltid treffer praksis. Dessuten dirigerer mesteren sannsynligvis kor på høyere nivå i sin egen praksis enn studentene gjør, dermed blir en repertoarbias ofte uunngåelig.

Mesterlære resonerer med Wegners konsept læring i praksisfellesskap (Lave \& Wenger, 1991), hvor mesteren gradvis fører den deltagende lærlingen fra periferi mot sentrum. Lærlingen mestrer stadig flere av de nødvendige kompetansene, og vedkommende gjennomgår en transformasjon fra dirigentlærling til fullverdig dirigent som tas opp i dirigentlauget. Mesterlæretradisjonen er sterk, men det finnes argumenter for en mer strukturert tilnærming (Durrant, 1994). Fordelen med en strukturert tilnærming er muligheten for å konsentrere seg om eksplisitte læringsobjekter. En nylig uteksaminert dirigent savnet sterkt «[a]t en lærer går inn og sier: Nå lærer vi det. Noen ganger var det litt diffust når det kom inn dirigentlærere. [Dirigentnavn] var god til det: Nå lærer vi dette». ${ }^{\mathrm{A}}$ En mellomposisjon er å betrakte studiet som et rammeverk, hvor studentene selv må forsyne seg av mange muligheter. Dette innebærer at det ikke er så viktig om undervisningen foregår på en bestemt måte; studentene må selv velge ut og anvende kunnskapen. Mye taler for at en fagsentrisk tilnærming bør kombineres med en mer dannelsessentrisk tilgang.

\section{Estetisk orientering - standardisering eller personlig uttrykk}

Utdanning kan dyrke standardiserte dirigeringskonvensjoner (dannelsessentrisk) eller personlige uttrykk (elevsentrisk). Gestikkfaget lener seg på formidling av konvensjoner, spesielt innenfor emner av begrenset 
omfang og varighet. Fortellingen til en av de intervjuede dirigentene i karriereundersøkelsen er talende for hvordan en for standardisert undervisning kan virke direkte disruptiv. Hun ble undervist av anerkjente dirigenter, men opplevde det slik:

[De] hadde sine måter å gjøre det på, som på en måte var fasit ... Når jeg skulle dirigere, da var det en slags dirigentdrakt jeg måtte ta på meg som var veldig, veldig trang. Og da gikk det ikke an å være meg selv.

Informanten vurderte å slutte å dirigere. Senere møtte hun en annen lærer i ensemblepraksis som var annerledes: «Hun var ekstremt åpen og oppmuntret meg til å være meg selv, faktisk, til å tørre å ha min egen stil og legge vekt på å kommunisere med koret. Og da klarte jeg å føle meg trygg.» Standardisering kan gjelde dirigentteknikk og kroppspråk, men også mer personlig stil, slik en nyutdannet dirigent formulerer det: «Jeg kan ikke være korleder her og Jonas der. 'Jonas, du må være mer skarp, for eksempel med barn'. Jeg må ha meg med.» ${ }^{\mathrm{A}}$

Dirigentlærerne vi har intervjuet, har interessante refleksjoner omkring denne tematikken som går i retning av at det personlige må dyrkes, ikke det standardiserte. En legger vekt på at studentene må finne lenken mellom «partituret og deres egen person». ${ }^{A}$ De må gjøre musikken til sin egen. En annen er opptatt av selvstendighet, at ikke studentene skal bli en kopi av læreren. Dermed vil de ende opp med å bli gode på ulike områder. En tredje sier det slik: «Hver person skal utvikles. ... Det finnes ingenting absolutt i dette. Det er viktig å se på individenes videreutdanning uansett nivå og kunnskaper ... Hva er mitt personlige uttrykk? Det tar jo et liv ...». "Man kan aldri lære ut det personlige», sies det også. ${ }^{\mathrm{A}}$

Noe av utfordringen ved dirigentrollen (som i enhver lederrolle) er at den består av to ulike fasetter: funksjon og person (Jansson, 2018). Det funksjonelle er i noen grad (men ikke helt) fundert på konvensjoner. For eksempel er synkroniseringsaspektet i hovedsak en funksjon, mens den musikalske ideen i større grad avspeiler personen. Det funksjonelle handler om at noen må fylle den delen av rollen, mens for det personlige betyr det noe hvem det er - kunstneren, mennesket, «meg». Rollen veksler mellom disse fasettene. 
I lys av det foregående kan vi gå tilbake til dirigentstudenten som opplevde undervisningen som en tvangstrøye. ${ }^{\mathrm{C}}$ Hun forteller videre:

Jeg har laget et eget kroppsspråk som dirigent ... en slags «empatisk dirigering», der jeg i tillegg til de tekniske tingene, som er sånne standard gester ... sender dem, med kroppen og ansiktet, det jeg ønsker at de selv skal formidle til publikum. Det er det jeg mener med «empatisk».

Dirigenten vektlegger at hun har utviklet dette språket selv: «Det er det som gjør at jeg er meg selv, og at jeg fungerer med den gruppa jeg dirigerer.» Nøkkelen for at hun kunne være seg selv, var at hun vektla egne kommunikasjonsmidler mer enn konvensjoner. Imidlertid har dirigentfaget konvensjoner som må læres som del av dannelsesprosjektet for å kunne fungere på tvers av ensembler. Spenningen mellom det standardiserte og det personlige kan neppe løses, men utdanninger kan forholde seg bevisst til den.

\section{Avsluttende bemerkninger}

De sju dilemmaene har ulike «eiere», det vil si at de opptrer på ulike nivåer - for den individuelle dirigentlæreren, for utdanningsinstitusjonen eller på politisk nivå (Angelo, 2014). Vårt anliggende har ikke vært å plassere ansvar, hvilket neppe kan gjøres på noen entydig måte, men å belyse hva som ligger i spenningene. Likevel vil dilemmaene som har mest med legitimering å gjøre, ha innslag av kulturpolitikk og institusjonell strategi, hvor både de enkelte tilbydere og arbeidsdelingen mellom institusjonene bidrar til løsning. Dilemmaene som har med gjennomføring å gjøre, berører programansvarlige og lærere. Men studentene selv bidrar også, idet de søker til ulike tilbud, til hvordan dilemmaene håndteres; ulike profiler dekkes av en form for markedsadferd. Oversøking og undersøking til ulike programmer har store konsekvenser for den faktiske utdanningskapasiteten.

Dilemmaene er løsbare i ulik grad. Praksisramme - pedagogisk ressurs eller profesjon - vil totalt sett måtte omfatte begge deler, selv om spenningen må avklares hos den enkelte institusjonen. Dette gjelder også omfang - dedikert eller del av annet program. Praksisfelt - bredde eller 
korspesialisering - er et spørsmål som slår inn på alle nivåer, siden det handler om både samfunnets behov og det konkrete undervisningsinnholdet. Dilemmaet tvinges dermed til ulike løsninger, uten at dilemmaet forsvinner på samfunnsnivå. Emnestruktur og didaktisk orientering hører tydelig hjemme på institusjonsnivå. For ethvert utdanningsprogram og enkeltemne vil dilemmaene måtte komme til en helt konkret avklaring. Pedagogisk kontra kunstnerisk orientering av utdanningen og individualisert uttrykk kontra konvensjoner er de to dilemmaene som i størst grad hviler på den enkelte dirigentlæreren - og dermed de facto alltid får en konkret løsning (selv om den ikke artikuleres).

De sju dilemmaene er distinkte i den forstand at de innebærer hver sin konkrete avveining. Samtidig henger de i noe ulik grad sammen ved at én bestemt håndtering setter rammer for de øvrige. Dilemmaene er mest synlige når institusjoner og lærere utformer undervisning - som intenderte opplegg. Et dilemma oppløses idet konkrete valg gjøres, i det minste for den instansen som gjør valget. Hvordan lærere gjennomfører oppleggene, gir rom for betydelig individualisering ut fra både lærerens profil og studentgruppen. Små klasser og utstrakt individuelt arbeid situerer læringen, uansett hvordan det formelle opplegget ser ut. Det vil ofte være store avvik mellom intenderte og realiserte opplegg (jf. Goodlad, 1979), så vel som i hvordan de oppleves av studentene. Enkelte spenningsakser vil ikke alltid være like synlige i den konkrete undervisningssituasjonen. Verdien av dilemmaene som er diskutert i dette kapitlet, ligger derfor i det helhetlige blikket som muliggjør en systematisk refleksjon over hva man vil med dirigentutdanning, hva den bør inneholde, og hvordan den kan utformes.

I dirigenters livsløp dominerer betydningen av praksis. Dømmekraften som mobiliseres i reelle ensemblerelasjoner og i øyeblikkskunsten, er ikke enkelt formbar som undervisningsstoff. De eksistensielle kompetansene kan knapt læres i det hele tatt, men heller dyrkes gjennom refleksiv praksis. Utdanning oppleves som nyttig, men overgang til praksis kan oppleves som et dramatisk sceneskifte. Som en nylig uteksaminert student uttrykker det: « $\AA$ komme ut i yrkeslivet etter endt utdanning er som å hoppe uten fallskjerm. Men det man har lært, kan folde seg ut når man faller.» ${ }^{\mathrm{A}}$ Dirigentutdanningen er som en forberedelse man ikke helt vet hvordan vil fungere. 
De underliggende studiene rettet oppmerksomheten på akademisk dirigentutdanning, samtidig som det foregår omfattende kursopplegg i regi av kororganisasjonene. Slike opplegg bidrar til å styrke det samlede tilbudet og dermed tone ned noen av dilemmaene. Likevel bør alle som befatter seg med kordirigentopplæring, forholde seg bevisst til de sju spenningsaksene med hensyn til legitimering og utforming av sine tilbud.

\section{Referanser}

Angelo, E. (2014). Kunstner eller lærer? Et illustrerende profesjonsdilemma i det musikk- og kunstpedagogiske landskapet. I E. Angelo \& S. Kalsnes (Red.), Profesjonsdilemmaer i musikk- og kunstpedagogisk utdanning (s. 21-41). Cappelen Damm Akademisk.

Apfelstadt, H. (1997). Applying leadership models in teaching choral conductors. Choral Journal of the American Choral Directors Association, 3(8), 23-30.

Armstrong, S. \& Armstrong, S. (1996). The conductor as transformational leader. Music Educators Journal, 82(6), 22-25.

Atik, Y. (1994). The conductor and the orchestra: Interactive aspects of the leadership process. Leadership and Organization Development Journal, 15(1), 22-28.

Bathurst, R. \& Ladkin, D. (2012) Performing leadership: Observations from the world of music. Administrative Sciences, 2(1), 99-119.

Bjørndal, B. \& Lieberg, S. (1978). Nye veier i didaktikken. Aschehoug.

Bonshor, M. J. (2017). Conductor feedback and the amateur singer: The role of criticism and praise in building choral confidence. Research Studies in Music Education, 39(2), 139-160.

Brunner, D. L. (1996). Carefully crafting the choral rehearsal. Music Educators Journal 83(3), 37-39.

Bush, M. (2011). Leading performance: Transposing musicianship into the leadership debate. Management in Education, 25(1), 37-41.

Cox, J. (1989). Rehearsal organizational structures used by successful high school choral directors. Journal of Research in Music Education, 37(3), 201-218.

Cresswell, J. W. \& Piano Clark, V. L. (2011). Designing and conducting mixed methods research. Sage Publications.

Daugherty, J. F. (1999). Spacing, formation, and choral sound: Preferences and perceptions of auditors and choristers. Journal of Research in Music Education, $47(3), 224-238$.

Daugherty, J. F., Manternach, J. N. \& Brunkan, M. C. (2013). Acoustic and perceptual measures of SATB choir performances on two types of portable choral riser units 
in three singer-spacing conditions. International Journal of Music Education, 31(3), 359-375.

Dunn, D. E. (1997). Effect of rehearsal hierarchy and reinforcement on attention, achievement, and attitude of selected choirs. Journal of Research in Music Education, 45(4), 547-567.

Durrant, C. (1994). Towards a model of effective communication: A case for structured teaching of conducting. British Journal of Music Education, 15(1), 40-49.

Durrant, C. (1998). Developing a choral conducting curriculum. British Journal of Music Education, 15(03), 303-16.

Durrant, C. (2003). Choral conducting: Philosophy and practice. Routledge.

Elstad, B. \& Jansson, D. (2020). From artist to manager. Working conditions, professional identity, and career satisfaction. Journal of Arts Management, Law, and Society 5o(3), 184-98. https://doi.org/10.1080/10632921.2020.1746717.

Floyd, E. \& Bradley, K. D. (2006). Teaching strategies related to successful sightsinging in Kentucky choral ensembles. Update: Applications of Research in Music Education, 25(1), 70-81.

Fuelberth, R. J. V. (2003). The effect of left hand conducting gesture on inappropriate vocal tension in individual singers. Bulletin of the Council for Research in Music Education, 157, 62-70.

Geisler, U. (2010). Choral research. A global bibliography. Körcentrum Syd.

Gherardi, S. \& Nicolini, D. (2002). Learning in a constellation of interconnected practices: Canon or dissonance? Journal of Management Studies, 39(4), 419-436.

Gonzo, C. (1973). Research in choral music: A perspective. Bulletin of the Council for Research in Music Education, 33, 21-33.

Goodlad, J. I. (1979). Curriculum inquiry: The study of curriculum practice. McGrawHill.

Goodstein, R. E. (1987). An investigation into leadership behaviors and descriptive characteristics of high school band directors in the United States. Journal of Research in Music Education, 35(1), 13-25.

Grant, J. \& Norris, C. (1998). Choral music education: A survey of research 1982-1995. Bulletin of the Council for Research in Music Education, 135, 21-59.

Grimen, H. (2008). Profesjon og kunnskap. I A. Molander \& L. I. Terum (Red.), Profesjonsstudier (s. 71-86). Universitetsforlaget.

Grimland, F. (2005). Characteristics of teacher-directed modeling in high school choral rehearsals. Update: Applications of Research in Music Education, 24(1), 5-14.

Gumm, A. J. (2018). Music conducting functions: A mixed-methods evaluation of theory and survey validity. Psychomusicology, 28(4), 189-200.

Hanken, I. M. \& Johansen, G. (2013). Musikkundervisningens didaktikk. Cappelen Damm Akademisk. 
Hunt, J. G., Stelluto, G. E. \& Hooijberg, R. (2004). Toward new-wave organization creativity: Beyond romance and analogy in the relationship between orchestraconductor leadership and musician creativity. The Leadership Quarterly, 15(1), $145-162$.

Hylton, J. (1983). A survey of choral education research. Bulletin of the Council for Research in Music Education, 76, 1-29.

Jansson, D. (2018). Leading musically. Routledge.

Jansson, D. (2019) Choral singers' perceptions of musical leadership. I G. Welch, D. Howard \& J. Nix (Red.), The Oxford handbook of singing (s. 865-885). Oxford University Press.

Jansson, D., Balsnes, A. H. \& Bygdeus, P. (2018). Nordic choral conductor education. Overview and research agenda. Nordic Research in Music Education. Yearbook, 19, 137-170.

Jansson, D. \& Balsnes, A. H. (2020). Choral conducting education: The life-long entanglement of competence, identity, and meaning. Research Studies in Music Education, 1(18).

Jansson, D., Elstad, B. \& Døving, E. (2019a). Choral conducting competences: Perceptions and priorities. Research Studies in Music Education. https://doi. org/10.1177/1321103X19843191.

Jansson, D., Elstad, B. \& Døving, E. (2019b). Universality and situatedness in educating choral conductors. Music Education Research, 21(4), 344-58. https:// doi.org/10.1080/14613808.2019.1626362.

Kalsnes, S. (2014). Kulturskolen som ressurssenter - konsekvenser for kulturskolelærerrollen? I E. Angelo \& S. Kalsnes (Red.), Profesjonsdilemmaer $i$ musikk- og kunstpedagogisk utdanning (s. 109-124). Cappelen Damm.

Korthagen, F. A. J. (2010). Situated learning theory and the pedagogy of teacher education: Towards an integrative view of teacher behavior and teacher learning. Teaching and Teacher Education, 26(1), 98-106.

Lave, J. \& Wenger, E. (1991). Situated learning: Legitimate peripheral participation. Cambridge University Press.

Lebrecht N. (1992). The maestro myth: Great conductors in pursuit of power. Simon \& Schuster.

Machida, M. \& Schaubroeck, J. (2011). The role of self-efficacy beliefs in leader development. Journal of Leadership and Organizational Studies, 18(4), 459-468.

Manternach, J. N. (2012). The effect of varied conductor preparatory gestures on singer upper body movement. Journal of Music Teacher Education, 22(1), 20-34.

Mintzberg, H. (1998). Covert leadership: Notes on managing professionals. Harvard Business Review, 76(6), 140-147.

Molander, A. \& Terum, L. I. (2008). Profesjonsstudier - en introduksjon. I A. Molander \& L. I. Terum (Red.), Profesjonsstudier (s. 13-26). Universitetsforlaget. 
Ng, P. T. \& Tan, C. (2009). Community of practice for teachers: Sensemaking or critical reflective learning? Reflective Practice, 10(1), 37-44.

Nielsen, F. V. (1998). Almoen musikdidaktik. Akademisk Forlag.

Nielsen, K. \& Kvale, S. (1999). Mesterloere. Loring som sosial praksis. Ad Notam Gyldendal.

Omidvar, O. \& Kislov, R. (2014). The evolution of the communities of practice approach: Toward knowledgeability in a landscape of practice - an interview with Etienne Wenger-Trayner. Journal of Management Inquiry, 23(3), 266-275.

Polyani, M. (200o). Den tause dimensjonen. En introduksjon til taus kunnskap. Spartacus.

Price, H. E. \& Byo, J. L. (2002). Rehearsing and conducting. I R. Parncutt \& G. E. McPherson (Red.), The science and psychology of music performance: Creative strategies for teaching and learning (s. 335-352). Oxford University Press,

Raelin, J. A. (2020). Toward a methodology for studying leadership-as-practice. Leadership, 16(4). https://doi.org/10.1177/1742715019882831

Rennie, D. L. (2012). Qualitative research as methodical hermeneutics. Psychological Methods, 17(3), 385-398. https://doi.org/10.1037/aoo29250

Schiavio, A. \& Høffding, S. (2015). Playing together without communicating? A prereflective and enactive account of joint musical performance. Musicae Scientiae, $19(4), 366-388$.

Schonberg, H. C. (1967). The great conductors. Simon \& Schuster.

Silvey, B. A. \& Major, M. L. (2014). Undergraduate music education majors' perceptions of their development as conductors: Insights from a basic conducting course. Research Studies in Music Education, 36(1), 75-89.

Simonsen, M. B. (2010). Profesjonalisering av kor. Norsk kulturråd og Fagbokforlaget. https://www.kulturradet.no/vis-publikasjon/-/publikasjonprofesjonalisering-av-kor

Sutherland, I. \& Jelinek, J. (2015). From experiential learning to aesthetic knowing: The arts in leadership development. Advances in Developing Human Resource, $17(3), 289-306$.

Ternström, S. (1994). Hearing myself with others: Sound levels in choral performance measured with separation of one's own voice from the rest of the choir. Journal of Voice, 8(4), 293-302.

Ternström, S. (2003). Choir acoustics: An overview of research published to date. International Journal of Research in Choral Singing, 1(1), 3-12.

Timmermans, S. \& Tavory, I. (2012). Theory construction in qualitative research: From grounded theory to abductive analysis. Sociological Theory, 3o(3), 167-186. https://doi.org/10.1177/0735275112457914

Vallo, V. J. (1990). Conducting and music education: A review of selected research. Update: Applications of Research in Music Education, 9(1), 13-16. 
van Knippenberg, D., van Knippenberg, B., De Cremer, D. \& Hogg, M. A. (2004). Leadership, self, and identity: A review and research agenda. The Leadership Quarterly, 15(6), 825-856.

Varvarigou, M. \& Durrant, C. (2011). Theoretical perspectives on the education of choral conductors: A suggested framework. British Journal of Music Education, 28(3), 325-338.

Weber, K. \& Glynn, M. A. (2006). Making sense with institutions: Context, thought and action in Karl Weick's theory. Organization Studies, 27(11), 1639-1660.

Weick, K. E., Sutcliffe, K. M. \& Obstfeld, D. (2005). Organizing and the process of sensemaking. Organization Science, 16(4), 409-421.

Wenger, E. (1998). Communities of practice. Learning, meaning and identities. Cambridge University Press.

Wis, R. M. (2002). The conductor as servant-leader. Music Educators Journal, 89(2), $17-23$.

Wöllner, C. \& Auhagen, W. (2008). Perceiving conductors' expressive gestures from different visual perspectives. An exploratory continuous response study. Music Perception: An Interdisciplinary Journal, 26(2), 129-143.

Yarbrough, C. (1975). Effect of magnitude of conductor behavior on students in selected mixed choruses. Journal of Research in Music Education, 23(2), 134-146.

Yarbrough, C. \& Madsen, K. (1998). The evaluation of teaching in choral rehearsals. Journal of Research in Music Education, 46(4), 469-481. 


\title{
Woman and Full Professor in Music Education - Work Experiences in the Field of Academia
}

\section{Carina Borgström Källén \\ University of Gothenburg}

\begin{abstract}
This chapter explores work experiences of female full professors in music education. By targeting this group, positions for music education as a discipline in the field of academia in conjunction with gender are being highlighted and discussed. The objective is to problematize constructions of expertise and excellence in relation to gender equality and consecrated positions within the departments where the professors in focus are working. As a theoretical framework Pierre Bourdieu's field theory combined with Raewyn Connell's gender theory is applied. The empirical data that underpin the study in focus consist of three focus group interviews conducted in 2018 with eight full professors in the Nordic countries. The study is inspired by narrative as a method for re-telling, and thematized collective and compiled stories from the participants' utterances constructed for the presentation of the data. In order to handle ethical demands a meta-method-meeting was developed for the study in focus, i.e. all participants were invited to collaborate on the design of the study, keeping transparency, ethics and anonymity in focus. The findings suggest that the professors' agency for claiming a core position at their departments, respectively, is dependent on what local gatekeepers consecrate as symbolic capital for the acknowledgement of expertise and excellence.
\end{abstract}

Keywords: academia, consecration, gender, music education, professor

Citation of this chapter: Borgström Källén, C. (2021). Woman and Full Professor in Music Education Work Experiences in the Field of Academia. In E. Angelo, J. Knigge, M. Sæther \& W. Waagen (Eds.), Higher Education as Context for Music Pedagogy Research (pp. 245-268). Cappelen Damm Akademisk. https://doi.org/10.23865/noasp.119.ch1o

License: CC BY-NC-ND 4.0. 
Music education in relation to gender equality raises questions that address teaching and learning in all kinds of school contexts, from preschool settings to higher music education. It also raises questions about the relations between music education, gender, power and positions in academia as a field (Bourdieu, 1988). In this chapter three focus group discussions that explore work experiences and career paths of eight female full professors in music education are being analyzed. The professors in question hold positions in higher music education at universities in the Nordic countries. By targeting this particular group, i.e. women that are research leaders and bearers of expertise, positions for music education as a discipline in academia in conjunction with gender constructions are being highlighted and discussed. The objective of the chapter is to problematize results from the study in focus that have implications for music education as a discipline. More precisely, the chapter aims at problematizing construction of expertise and excellence within the discipline, in relation to gender equality and consecrated positions. The following questions are formulated: What is at stake for female professors' careers in music education within the field of academia? What positions and symbolic capitals are consecrated in the departments where the professors are working?

\section{Women in the Field of Academia}

No study has been identified that explicitly investigates the working situation for female, full professors in music education. Related research from a wider scope is therefore presented. Gender studies of women in the field of academia in general comprise a large body, and research from the last two decades, focusing Western universities, show gender inequality among the staff (Acker, 2010, 2012, 2014; Acker \& Webber, 2009; Kalm, 2019). These studies point at a complexity, and at a paradox, when gender representation is used as a measure of equality. The number of women on all academic levels is increasing in the Western countries, and the majority of undergraduate students are women. The paradox is that inequality remains, but more subtle than before. It is for 
example noticed that men are still holding prestige positions, a fact that cannot only be explained by age, discipline and generation (Bondestam \& Grip, 2015).

It is also shown that women in academe do a lot more so-called gluework (Acker \& Webber, 2009), or housekeeping (Kalm, 2019) than men do, work-tasks that do not merit you as a researcher, but still have to be done to keep things running at a department. According to Kalm (2019) women carry out a disproportionate share of academic housekeeping tasks, affecting a complex set of factors, such as the publish or perishrelated competitive academic culture, researcher ideals and gender norms. She stresses that "unbalanced academic housekeeping allocation may partially account for women's difficulties in advancing within academia” (Kalm, 2019; p. 5). Gender representation in academia is also described as a pyramid, where the base, the bachelor level, has a majority of women, while the top, the full professor level, is represented by approximately $75 \%$ men, depending on the discipline and the country (Bondestam \& Grip, 2015; Kalm, 2019).

Research exploring the structures of drafting committees for research funding show a pattern of underrepresentation connected to gender and race in the boards (Husu \& de Cheveigné, 2010). Studies stress the importance of gender equity when nominating to these positions, since they offer valuable experience and useful knowledge when writing research funding applications (Bondestam \& Grip, 2015; Husu \& de Cheveigné 2010).

\section{Women in Music Education}

The body of research in music education and gender shows that music teaching and learning in a variety of aspects is an arena for stereotyped gender performances. This is displayed as gendered constructions regarding for example choice of instrument and genre (Abeles, 2009; Borgström Källén, 2014; Green, 1997; Pellegrinelli, 2008; Wych, 2012), the possibility to claim space (Björck, 2011; Ferm Almqvist, 2019), power relations (Abramo, 2009; Armstrong, 2011; Borgström Källén, 2014; Green, 1997) and subordination from a LGBTQ perspective (Bergonzi, 2015; 
Gould, 2012). Research also emphasizes the impact of context and discourse for how gender is constructed in the music classroom (Borgström Källén \& Lindgren, 2017, 2018). An inertness over time regarding changing stereotyped gender performances is also highlighted (Abeles, 2009).

Research on gender equality and higher music education has focused mainly on the student perspective (de Boise, 2018). de Boise's (2018) study on gender equality in higher music education in Sweden and in the UK, shows less institutional discrimination against women in Sweden than in the UK, but at the same time that the gendered subject choices are transnational. He argues that a critique of neoliberalism together with an intersectional take is essential to tackling gender inequalities in higher music education.

Only a handful of studies related to women and academic careers within music education are identified (Blix et al., 2019; Dyndahl et al., 2017; Wieland Howe, 2009). The findings of these studies correspond with research from academia in general, suggesting that gender inequality still remains but is more subtle than previously shown. Blix et al. (2019) show a gender impact when applications for promotion to associate and full professor are evaluated within the Arts in Norway. According to Blix et al. gender inequality is shown both in experts' reports and when the applicants themselves are grading their value of quality in their specific subject. The study implies that subject specialists are operationalizing their own understanding of quality when assessing applications for promotion, using markers like scene, type of audience, creativity and relations for cooperation as starting points. According to Blix et al. insufficient criteria for quality along with a hegemonic elite discourse in Arts education lead to the fact that the power to define quality remains in the hands of those who already hold the definitions. The conclusion of the study is an urgent need for explicit criteria of quality in the performing arts at the level of associate and full professor.

Dyndahl et al. (2017) show a gender effect on supervising master and $\mathrm{PhD}$ theses in popular music in Norway. They conclude that there is a gendered division of labor regarding what kind of subjects, taking all music subjects into account, men and women are supervising respectively. Male professors are supervising over $80 \%$ of the theses on popular 
music. The study suggests that "when women introduce popular music to the music academic field in Norway in the role of supervisors, it happens through its implicit (and rather tacit) inclusion in music education and music therapy practices" (Dyndahl et al., 2017, p. 448). Thus, their findings suggest that when women supervise theses in popular music it is more often than not embedded in education or music therapy.

Wieland Howe (2009) views women in music education careers from a historical perspective. Not so surprisingly, there has been great improvements regarding female representation and impact in the discipline if looking back a hundred years, but nevertheless she concludes that there is much more to be done before music education offers equal opportunities for men and women. In the second half of the twentieth century there have been many opportunities for women in music education to edit journals and serve on editorial boards. However, according to Wieland Howe there is still, in 2009, a hierarchical division of labor within the discipline. She shows that women have always had numerous opportunities in the fields of music and education because parts of those fields can be regarded as extensions of activities performed in the home. Wieland Howe points out, that if looking at female music educators today it may seem as if there are no "musical ceilings" (Wieland Howe, 2009, p. 177) and no gender bias. However, she concludes, women are concentrated in certain areas, such as early childhood and general music. Following Wieland Howe there is no problem when talking representation in the discipline of music education as a whole, but when going into detail the same patterns as in the field of academia in general is shown, i.e. women are more likely to be positioned in areas not considered as high status, while men are more likely to be positioned in areas with high status.

\section{Field and Gender}

For analyzing the data parts of Pierre Bourdieu's field theory (1986, 2000), specifically focusing academia as a field (1988), is applied, together with Raewyn Connell's gender theory (2009), emphasizing power and division of labor. According to Bourdieu, a field is defined as a place for games, i.e. a place for competition between individuals and institutions battling 
for the same object. This requires specialists, value hierarchies and real or symbolic institutions. Examples of fields, according to Bourdieu, are the Academic field, the Cultural field, the field of music and the field of the arts (Bourdieu, 1986, 1993, 2000). Characteristics of a field are that it is regarded as autonomous, with specific rules and values and with contesting poles that are constructed by the actors within the field (Bourdieu, 2000).

The actors, or the players within the field, are hierarchically positioned, and they are competing for coveted positions on the basis of how the field evaluates their capital. The value of a specific capital is not static, instead it is related to what is privileged in each field. According to Bourdieu (1986) social capital refers to the network of people one has that enables oneself to maintain one's position in a social hierarchical system. In a gender perspective, social capital has been applied as an explanation to why women have difficulty reaching top positions in many professions (Griffin, 2017). The argument is that men support each other by gaining social capital in homosocial networks. Cultural capital is according to Bourdieu referring to assets that are not economic, but still enable social mobility.

Symbolic capital refers to the amount of prestige a player has, equaled with a reputation of competence and an image of respectability, i.e. the symbolic capital legitimizes the other forms of capital a player possesses. Social and cultural capital only reinforce social status if recognized in the form of symbolic capital (Bourdieu, 1986, 200o), and it is obtained when the player is consecrated by others in the field. A field also needs established hallmarks, or consecration instances, (artefacts like artists and classical canons) to obtain commitment and dedication for the game. Thus, the concept consecration describes how actors in a field are embraced and celebrated by other actors, acting as stakeholders or gatekeepers (Bourdieu, 200o). To consecrate someone is to create and maintain an aura of admiration and mysticism that surrounds an individual or a group of individuals within a specific field. Consecration can therefore be constructed with different kinds of symbolic capital depending on what is regarded as valuable. Bourdieu (1993) emphasizes the role of relevant gatekeepers as agents of consecration, since authority to produce symbolic capital is needed. 
Cattani et al. (2014) stress the importance of taking the allocation between peripheral players and core players in a field into account, whether in science or in art. The peripheral players are challenging the core players when moving from the periphery of the field to the core. This struggle has been conceptualized by Bourdieu in various ways (1993, p. 83), as dichotomies between incumbents and dissidents, insiders and outsiders, orthodox and heretics, and core and peripheral players. Cattini et al. (2014) argue that core players are more likely to defend orthodoxy because their symbolic capital is already embedded in the field, while peripheral players are more likely to depart from the field's canons and expectations.

According to Connell (2009), gender has a unique position among social constructions, since it is addressed to our bodies and plays on the reproductive differences through the reproductive arena (Connell, 2009, pp. 66-71). The body thus becomes simultaneously both agent and object in a social practice. This practice is called social embodiment (Connell, 2009, p. 66). Connell (2009) divides gender relations into four interlocking dimensions - power relations, production relations, emotional relations and symbolic relations (2009, pp. 75-85). In this chapter power relations will be applied to analyze gendered hierarchical positions in the academic field. Production relations are used to interpret gendered divisions of labour. In order to link Bourdieu to gender theory Adkins and Skeggs (2004), is applied, since Bourdieu had, despite his work Masculine domination (2001), little to say about gender and women (Adkins \& Skeggs, 2004). Adkins stresses that Bourdieu's theoretical apparatus can contribute to developing analysis of gender equality (Adkins \& Skeggs, 2004). She compares with how feminist researchers, such as Butler (1993) and Frazer (1997), have deployed and developed theorists as Habermas and Foucault in directions towards feminist perspectives, even though they, like Bourdieu, had substantively little to say about feminism and gender. Adkins concludes that Bourdieu's lack of attention to gender and feminist theory must be located as typical of his contemporaries (Adkins \& Skeggs, 2004, pp. 4-6), and she argues that his theory is fruitful for contemporary feminist theory. Three of her arguments are particularly relevant for this study. Firstly, because Bourdieu claims that social action 
is always embodied, secondly since power is subtly inculcated through the body and thirdly because Bourdieu emphasizes the politics of cultural recognition and social position taking. During the last decades a body of gender related research has been accumulated with Bourdieu as a theoretical framework (Adkins \& Skeggs, 2004) and his framework is also applied by a number of researchers in music education and musicology for analyzing musical fields (Burnard et al., 2015; Dyndahl, 2002; Nerland, 2003; Nylander, 2014).

\section{Methodology - Ethical Quandaries as Guidance for Design}

This study has been conducted in close collaboration with the participants, since anonymity and ethical considerations are demanding a great deal of attention. Mainly because full professors in music education in the Nordic countries constitute a small number, and strategies on how to avoid identification had to be discussed thoroughly. The empirical material consists of three focus group discussions (Dahlin-Ivanoff, 2018, pp. 81-92) with eight full professors, holding positions in music education in the Nordic countries. The interviews generated in total seven hours of recorded data.

A meta-method-meeting (MMM) was applied in order to handle ethical demands within the study. The concept meta-method-meeting was developed and elaborated by me as a tool for ethical considerations connected to the study. In a meta-method-meeting all participants are invited to collaborate in the design of a study, keeping transparency, eth$i c s$ and anonymity in focus. When asking informants for consent the ethical demands were described and a meta-method-meeting was suggested. The meeting took place with six of the eight participants. The professors that did not participate in this meeting agreed beforehand to approve of the decisions made at the meeting. It was also decided that the meeting should be described as a crucial part of the study's methodology. At the meeting a meta-method-plan was constructed, concerning primarily two issues: (1) how to address the participants, their colleagues and their workplaces to avoid identification (2) agreements how to make it possible 
for the participants to edit and approve their own transcribed excerpts to further avoid identification.

To address the ethical dilemma posed by the second issue a strategy was agreed upon; each informant would read an anonymized version of the transcripts, from their own focus group, where identification markers such as names, departments, faculties, specific titles and places were already removed. The participants would be able to delete, rephrase or disguise their utterances in their own excerpts if they find them problematic when it comes to anonymity and ethics.

According to Esaiasson et al. (2012, pp. 318-326) focus groups are especially suitable for studies investigating delicate subjects, such as individuals' personal experiences at a workplace where they still are working, since the group members could gain strength from each other. But Esaiasson et al. also point out the risk of members in the focus group disseminating what was said during the interview since they, as opposed to the researcher, are not obliged to keep silent about what members in the group were saying. With this in mind all participants signed a contract of non-disclosure, designed by me and approved by the meta-group, in which they promised to keep silent of what was said.

In the letter of consent, the participants were informed of the plans to construct the transcripts into collective, compiled narratives (De Fina \& Georgakopoulou, 2015) of three fictitious full professors, using the narratives as a form for presentation of the result. The participants all agreed upon that it was a fruitful way of handling the dilemmas with anonymization.

At the meta-method-meeting key-questions, prepared in a protocol for study (Dahlin-Ivanoff, 2018) were discussed. By sharing the questions beforehand, the participants were given the opportunity to discuss the themes and propose changes within the frame of the overall objective of the study. The group decided on deleting one question and adding two new ones. The new questions were formulated at the meeting and added to the protocol of study. Hereby, the meta-method-meeting co-constructed not only the design and the ethical conditions of the study, but it also slightly affected the objective and hence the outcome. The themes agreed upon for the three focus groups were as follows: career, current work situation, responsibility and power, knowledge to hold in trust, limits and 
constraints for music education as a discipline, possibilities and restrictions in relation to gender.

Finally, the dilemma concerning translation was discussed at the meta-method-meeting. A valid Swedish transcript out of utterances made on several languages is a challenge, risking translations that misinterpret the informants' intentions. I proposed, if unsure of the correct translation, that I should write what I heard in the original language as I heard it and then combine this incorrectly spelled utterance with a suggestion how to translate it into Swedish and English. Thereby the informants could see, when they read the transcripts, both what they actually said and my suggestions how to translate it. The meeting participants agreed and when the informants read the transcripts, I was in a dialogue with each one of them concerning the translation.

The analysis was conducted in three steps. Firstly, a categorization was made, using the questions from the protocol of study as a basis. In the second step the categories identified were thematized and three contrasting positions emerged in the material. As the third step the narratives were constructed, i.e. three different positions were composed into the narratives of fictitious professors Andersen, Johansen and Olsen. In the result excerpts from the three narratives are presented. Since I am using narratives to construct themes for analysis, using excerpts from those narratives to present the data, the study is not ontologically and epistemologically regarded as a narrative inquiry (Clandinin, 2007). Rather, it is inspired by narrative as a theory for re-telling (Barrett \& Stauffer, 2009; De Fina \& Georgakopoulou, 2015) and from theories on neo-narrative methodology (Stewart, 2010). By using narratives, or excerpts of narratives, as the form for presentation it is possible to construct three fictitious professors, Andersen, Johansen and Olsen, and still be able to keep the participants anonymous.

\section{The Narratives of Professors Andersen, Olsen and Johansen}

Below the analysis of the narratives of the fictitious professors Andersen, Johansen and Olsen is presented, starting with a short description of the three. 
Similarities are shown regarding the professors' background. All three are raised in a Nordic country and they have similar educational background, including preparatory music schools since early childhood, a music teacher education and a $\mathrm{PhD}$ in music education. They describe their early career into the $\mathrm{PhD}$ programme in a similar, but somewhat contradictory way. This first step into a career as a researcher in music education is on the one hand described as something coincidental, something not planned for, but on the other hand as something they were "drawn to" (professor Johansen). A desire to find spaces to learn more and to "try to reach the ceiling with new ways of thinking" (professor Andersen) and "get a language for all the questions" (professor Olsen). All three emphasize the huge importance of the Nordic Network for Research in Music Education (NNRME), which they refer to as their "home".

Talking with Bourdieu the similar educational background of the three professors can be interpreted as if they were actors in the field of music long before they entered the field of academia. They all describe the entrance into the academic field as ambiguous and insecure, speaking of a need for a social network of peers, the NNRME, to feel comfortable. The network functioned as a way to build up a social capital viable in the new field, and as a bridge of security between the field of music, where the rules of conduct were known and where they knew their positions, and the academic field, where they were trying to learn how to play the game.

Currently, professor Andersen and professor Olsen work at departments that train teachers in all kinds of subjects and for a variety of school forms, such as pre-school teachers and secondary school teachers; a part of the Academic field where pedagogical competence in general is emphasized. Professor Johansen works at a department where music education is embedded in an environment where professional musicians are being trained and where music as art is emphasized.

\section{Gender Equality and the Professors Work Places}

All three professors describe an extremely heavy workload. However, they interpret their experiences as a woman in the field of academia in 
different ways. Professor Andersen talks about her heavy workload and the pressure from colleagues without explicitly connecting it to gender. She says that there is a majority of women at her department and that she feels respected for who she is. Though, she adds, the reason for her not having to think about gender is that women in the past paved the way.

Professor Andersen: In my department there's a majority of women and some of us are full professors. As a woman I always feel respected. I have never felt that gender is a hindrance in my career. Have always known that if you want something done you have to do it yourself. Some people are like a pain in the ass, regardless of their gender. But I can say that I am privileged, because I don't have to think about gender in my everyday life and I understand that this is because women in the past did the hard work, both in NNRME and at my department. Therefore, I feel that I am obliged to help the next generation. Because I did not receive any help until I was almost already merited as a professor. At that time, I got a coach, an elderly male professor with many years of experience. He was someone I could talk to.

In the excerpt above professor Andersen describes herself as a woman who does not experience gender oppression at her workplace. She admits that colleagues can be hard to cooperate with and that some of them behave badly, but argues that these behaviors are connected to individuals regardless of their gender. Her analysis is that she is privileged, since other women paved the way and that is why she can work without thinking of gender as a hindrance. In the narrative she emphasizes her own strength and persistency as means to get things done.

Professor Olsen speaks of two aspects of gender inequality. Firstly, as a problem from the past, something that occurred before her entrance to the academy. She emphasizes, like professor Andersen, that she is aware of the privilege of not having to speak about gender, and she refers to the women with a specific kind of strength in the previous generation who paved the way. Secondly however, Olsen recognizes more subtle expressions of gender inequality at her department, related to the division of labour and power. She has noticed that women in her department tend 
to do more caring work and more so-called glue-work, or housekeeping than men, and that work tasks conducted by men receive a lot more praise.

Professor Olsen: I am convinced that I reached my position as full professor because of all the "strong women" in my department. They've involved me in lots of exciting projects, given me advice like "don't let it bother you". There have been men who've been rather arrogant, but with the strong women in the background I've had the strength to handle it. These are women who are very clear and forceful in their argumentation. They are thick-skinned and have been good role models. I've felt the pressure to quickly become a professor, but I can see now that I lacked female professor role models early on in my career. What if it's deteriorating terms and status that make it possible for women to become professors? If terms were what they once were, maybe the position wouldn't have been available to us. There's also something about the caring tasks that women perform to a greater extent than men. I think you become more harshly judged as a woman if you say no and send the students down the hall. But it becomes a hindrance, because it takes time. And there's something about the way men often boast about themselves. Men speak of their work in a way that gives them status. If you're saying that an assignment is important, you're also saying that you have to devote a lot of time to it. Not saying it out loud will backfire. Competent girl shoots herself in the foot. Are women so happy about their little shred of influence that we just go with the stream and do what's expected?

Professor Olsen is praising other women at her department for leading the way for her career. She describes them as strong, thick-skinned, and as forceful in their argumentation and she is thanking them, and not herself, for her position in academia. But despite the strong women and their power, she has experienced gender inequality, constructed in subtle ways, and shown as gendered divisions of labour and power relations that elevate and celebrate ordinary work tasks if they are conducted by men.

Professor Johansen describes her work situation as if gender inequality is a struggle and an everyday problem. She compares her situation with 
male professors in music education in the generation before her and concludes that they never would have accepted the terms she works under. She describes how gender inequality is shown in almost all her work tasks; a heavy workload, feelings of being diminished and disempowered, a feeling of guilt if not being helpful and being objectified as woman.

Professor Johansen: I'm getting positioned as a woman all the time. It's happening in situations where I'm the one who's most qualified. When I claim space I'm seen as troublesome, and that's when I realize that I'm a woman. The goal is that we shouldn't have to talk about gender. But there's been more focus from the ministry, because there a too few female professors at Music Academies in general. I'm grateful for having participated in a program enhancing the careers of female university graduates. But it's regarded as vip lane, as if you're admitted on quota. Then you have to prove yourself and be twice as good. When I was promoted there was no great cheering. I'd hoped that they'd say: "Finally, a female professor to improve the statistics." But no. I've been discriminated so many times I've lost count. I don't have the strength to fight anymore. A striking example is when a male colleague was asked to become the head of postgraduate studies as a full-time position. Later, when I got the question, the assignment had been reduced to $20 \%$. Or when my meetings are ignored, and people don't respond to E-mails. I have had to work extremely hard with tasks that are not normally that of a professor. Teaching at all levels. Supervising bachelors. At the same time, I'm expected to do everything that's included in my function as a professor. I've been working every summer and basically every weekend. When I brought this up with my boss, she suggested I should contact a psychologist to have someone to talk to. And I've often been disparaged. At a staff meeting a boss said: "Imagine, our little girl has become a professor here." Becoming a professor actually reduced my power. I haven't been backed up by the strong women that the two of you speak of. The ones in corresponding positions with us are almost all men and great artists. On paper I'm a professor, but at my department I'm positioned as a woman working in pedagogy. They think research on young children is of no value, and you become positioned even more as a woman. 
Professor Johansen describes her work situation as a constant struggle and as she is positioned as a peripherical player at her department. She feels objectified as a woman and she expresses that she lacks power to change her situation. Her title as a professor does not give her the symbolic capital she needs, since the consecration instances at her department are celebrated artefacts in the arts, such as compositions or concerts. Hallmarks that are out of reach for her.

When listening to professor Andersen and Olsen it is clear that they have authority as professors at their departments. They talk about their promotion as a condition for making their voice heard, a way of influencing their departments. They express how the title makes it possible to work for music education as a discipline within their departments, and how the title has moved them from a peripherical position to a position closer to the core.

Professor Olsen: I benefit somewhat from my title as a professor, and can use the time as it was originally intended. Exerting influence on subject fields. So the title of professor has really opened doors. Previously, when I spoke of the status of music pedagogy, it was like calling out into empty space. Nobody felt addressed by the criticism, but with the title of professor I can make a difference.

Professor Andersen: As a professor I have the power to improve education. Somehow it gives me support, and that came as a surprise to me. Suddenly the things I said carried more weight. And suddenly other doors opened. I was expected to take the lead in various situations. The department leadership turn to me when they need subject legitimacy.

The promotion to professor works as a symbolic capital for professor Andersen and professor Olsen, moving them close to the core players at their departments. For professor Johansen, however, the effects of the promotion are the opposite. She is disempowered by core players at her department and she is positioned rather as a woman working in pedagogy. 


\section{Double Subordination?}

In this section, what I call a double subordination is focused, i.e. when gender and music education in conjunction work as deconsecrating instances that position the actors as peripherical and disempowered players in the field. In all three departments where the professors work music education is positioned as peripheral, and the subject is called into question by players from other disciplines. However, the actors that are constructed as having core positions vary. Andersen and Olsen describe how music education is seen as something strange, exotic, and something that the stakeholders are unsure of how to deal with. At their departments players compete with scientific merits for a position in the core, and the stakeholders ask for consecration instances such as scientific papers published in highly ranked journals, successful funding applications and international scientific networks. At professor Johansen's department the core players are the performing musicians and the creative artists, some of them promoted to professors in the Arts. And the consecrated instances are artefacts such as compositions and artistic performances that peers have the authority to turn into symbolic capital, i.e. it is the reputation as an artist rather than scientific merits that consecrate the core players in the department where professor Johansen works.

In the excerpt below professor Olsen is reflecting on her status as professor in music education in relation to her position in the field of academia, i.e. the educational context. She compares her own department, in teacher education, with departments of musicology and music performance, and argues that power and impact related to the title as full professor seem to be related to the context you are in.

Professor Olsen: It is of importance that we are a faculty for teacher education, and not an academy of music. Had it been musicology or at an academy of music, I think it would have been more difficult. In those contexts there are particular challenges. And it's not just the subject, something seems to happen when it's connected to gender. We have no artistically promoted professors. 
In the excerpt above Olsen suggests that there can be particular challenges at a department of musicology or an academy of music if you are a woman and hold a position in music education. She analyses the situation as if the subject music education intersects with gender, suggesting that this conjunction constructs subordination. She is also implicitly claiming that the fact that her department lacks artistically promoted professors makes it easier for her to position herself as a core player.

The narrative of Andersen does not imply double subordination, instead it points at a pole in the academic field where the title full professor in music education works as a symbolic capital. However, her narrative shows that music education as a discipline is subordinated at her department, questioned and contested by competing disciplines.

Professor Andersen: I have felt that music pedagogy as a discipline is under attack from various quarters. On the one hand from a tradition that says that music education should be transformed into liberal arts, on the other hand from practicing musicians who claim that they know music education since they teach music. It has been provocative to some that music education can be its own subject field with its own traditions. We have to fence the subject in, with reference to the Nordic community. That will be our salvation. But it's trying that you need to have those kinds of discussions with colleagues.

The excerpts show how the definition of music education is contested by players in competing disciplines at Andersen's department, attacked by liberal arts and by music teachers who claim a preferential right of interpretation when it comes to music education. Andersen stresses a need to frame the discipline with the help of the research network in NNRME. Talking with Bourdieu, the position for Andersen could be interpreted as if gatekeepers and stakeholders at her department make it possible for her to claim a core position as a female professor, as long as she does not try to use music education as a symbolic capital for competing. If she is using her title as professor as a consecrated instance, working on a general level for her department, she can be consecrated by gatekeepers and stakeholders within the field. 
Professor Johansen experiences music education as subordinated, or peripheral, at the department where she works. She also describes her position as a female professor as subordinated. In the following excerpt this double subordination is shown. Professor Johansen is focusing on experiences of being subordinated due to how stakeholders consecrate male artists with genius. A construction that subordinates the professor both as female and as representing the "wrong" discipline. She speaks about experiencing a difference between how she is being positioned inside and outside her department respectively, and of how she adapts to the gatekeepers' rules at her department as a strategy for acceptance. As an example of the latter she describes how she is emphasizing her research on higher music education rather than that on young children. Finally, the line organization as a tool for double subordination is focused by professor Johansen.

Professor Johansen: The idea of the male genius being supremely elevated lives on. In addition, pedagogy is ranked at the bottom. I'm doubly subordinated, which is degrading. Around me there are a lot of male artistically promoted professors who take the liberty of defining my subject. All of the promoted professors are men, I think. There are three categories of men I have to relate to. Most highly ranked are men who are artistically promoted professors. Any bullshit thing they say turns into highly relevant information. Then there are male professors with a doctorate in the wider field of arts and culture. They have become some kind of know-it-alls who speak with great authority. Much cooler than female professors with a $\mathrm{PhD}$ in music education. The third category is male bosses who have been practicing musicians or music teachers. They see me as a threat. I have to be very aware of the chain of command, and not fancy myself just because I'm a professor with a doctorate. Yet they haven't read any of my publications. I was the only woman in a steering group once. Either you kept quiet or else you were a nuisance. Strategy documents that I had written weren't used at all. The preferential right of interpretation was given to someone who knows nothing about music education. In other parts of the university and in international networks, I have influence. But at my own department, where decisions about strategic funding are made, that power is very 
limited. Usually it's non doctorates in artistic fields who set the agenda and define music education. So, I've realized that I have to speak louder about higher music education. It's all about who gets appointed to these head positions. If they know anything about pedagogy and research. Not even the head at our faculty has a doctorate, something that would never be found anywhere else at the university. The line organization is very powerful. I was shocked when I realized that the conditions had changed totally compared to my predecessor's. I think it's important to have research in music pedagogy at a university offering music education. But you shouldn't have to bend over backwards, change your vocabulary and pretend to be more of an artist than you are. You shouldn't have to navigate in that manner just to do your job. It's silly at a university, but these are powerful structures.

Professor Johansen expresses a significant double subordination, disempowered both as a female and as a professor in music education. This double subordination can be interpreted as a conjunction of an epistemological and social erasure. Professor Johansen is positioned as if she lacks relevant expertise and as if she is invisible to the core players at her department. But her narrative is contradictory since she also describes her position as if she is threatening the core actors, as they realize that her expertise, measured in scientific merits, is contesting the core players symbolic capital and thereby their position as consecrated artists and professors of the arts.

To sum up the findings, the experiences of subordination differ between the three professors. However, all three have experienced competing players from other disciplines, i.e. actors that have contested the professors' position as experts in music education, and they all describe a struggle voicing music education. Professor Andersen is struggling to get recognition and a position for music education as a discipline, but she is satisfied with her position as a female professor in general. Professor Olsen talks about music education as peripheral, but that her promotion has given her a position where she can act. She also points at her workplace as in some aspects affected by gender, when talking about housekeeping, or glue-work, in academia (Acker \& Webber, 2009; Kalm, 2019), work tasks that consume time but do not merit you, but she does not talk about herself as being oppressed 
or subordinated. For professor Johansen a significant double subordination is found and she expresses a frustration over her situation. She feels objectified as a woman and she also expresses a lack of respect at her department for her expertise as a professor.

\section{Conclusions}

This study shows that the amount of prestige the professors possess, respectively, to a large extent is a matter of where in the Academic field they are positioned. If they work at a department where teacher education and educational science are in focus, it is more likely that their title as professor functions as a consecration instance and thereby produce symbolic capital. If working at a department where music as an art form is in the forefront, the title professor of music education does not render any honour or praise. Symbolic capital is hard to access on scientific merits since the gatekeepers celebrate other kinds of consecration instances, such as being a highly ranked performing musician or a professor in composition.

Findings also suggest that the workplaces could be interpreted as two subfields, the music academy and the teacher education. This is, since they appear to be, at least to some extent, autonomous regarding the rules for playing the game successfully, i.e. the competition is based on hallmarks for expertise and excellence specific for each subfield. The consecration instances in the subfield music academy are, according to professor Johansen's experience closely connected to the field of the arts, while the field of teacher education, according to professors Andersen and Olsen, is tied to the field of education. Perhaps the structures of gendered power relations shown in research in the field of music (Citron, 1993; Ganetz, 2009; Green, 1997; Leonard, 2007; Lorentzen, 2009; McClary, 1991) are also viable for the double subordination of professor Johansen. The symbolic capital that consecrates artists in the public arena are in that case also measuring what is regarded as consecration instances at the Music academy where professor Johansen works. If so, is it possible to compete for a core position if not measured by standards from the field of the Arts?

Women as housekeepers, or glue-workers, in academia are highlighted in research in recent years. That is, research shows that women are doing 
work that does not bring merit, but has to be done to keep a department running, such as administrative work and caring for the well-being of students and colleagues. When looking at the findings in this study the professors are reflecting over their heavy workload and especially professor Olsen and professor Johansen comments on being overwhelmed by housekeeping tasks that they feel obliged to do but that are affecting their everyday work since they are time-consuming.

Finally, implications for music education research need to be problematized in relation to the findings. The subordination of music education as a discipline, experienced by all three professors, and the gendered subordination shown mainly in professor Johansen's workplace, but also to some extent in professor Olsen's, is problematic for music education research in the long run. If women have less time allocated for research, since they conduct more housekeeping and glue-work (Acker \& Webber, 2009; Kalm, 2019) or caring work that does not brings merit but is time-consuming, and if they are discriminated and socially ignored because of their gender, it will affect the outcome of music education research. As full professors in music education, Andersen, Olsen and Johansen function as role models, within and outside their departments, for assistant and associate professors as well as for $\mathrm{PhD}$ and master students. It is therefore relevant to argue that if the professors are being positioned as peripheral actors by their departments, it has an effect not only on their self-esteem as professionals, but also on music education as a research field. If female professors are deconsecrated and disempowered it is implicitly shown that their expertise and research are of less value. A conclusion from the findings might be that music education needs specific contexts for its persistence, and perhaps an increased focus on gender equality in departments where the liberal arts and the performing arts are positioned in the forefront.

\section{References}

Abeles, H. (2009). Are musical instrument gender associations changing? Journal of research in music education, 57, 127-139. http://jrm.sagepub.com/content/57/2/127 Abramo, J. M. (2009). Popular music and gender in the classroom [Doctoral dissertation]. Columbia University. ProQuest LLC. 
Acker, S., \& Webber, M. (2009). Women working in academe: Approach with care. In C. Skelton, B. Francis, \& L. Smulyan (Eds.), The Sage handbook of gender and education (pp. 483-496). Sage.

Acker, S. (2010). Gendered games in academic leadership. International Studies in Sociology of Education, 2o(2), 129-152. https://doi.org/10.1080/09620214.2010.503 062

Acker, S. (2012). Chairing and caring: Gendered dimensions of leadership in academe. Gender and Education, 24(4), 411-428. https://doi.org/10.1080/0954025 3.2011.628927

Acker, S. (2014). A foot in the revolving door? Women academics in lower-middle management. Higher Education Research and Development, 33(1), 73-85. https:// doi.org/10.1080/07294360.2013.864615

Adkins, L., \& Skeggs, B. (2004). Feminism after Bourdieu. Blackwell.

Armstrong, V. (2011). Technology and the gendering of music education. Ashgate.

Barrett, M., \& Stauffer, S. L. (2009). Narrative inquiry in music education. Troubling certainty. Springer.

Bergonzi, L. S. (2015). Gender and sexual diversity challenges (for socially just) music education. In C. Benedict, P. Schmidt, G. Spruce, \& P. Woodford (Eds.), The Oxford handbook of social justice in music education. https:/global.oup.com/ academic/product/the-oxford-handbook-of-social-justice-in-music-education9780199356157 ?cc=se\&lang=en\&\#

Björck, C. (2011). Claiming space. Discourses on gender, popular music and social change [Doctoral dissertation, University of Gothenburg]. https://gupea.ub.gu.se/ handle/2077/24290

Blix, H. S., Mittner, L., \& Gjærum, R. G. (2019). I kjønneste orden? Kvalitet og betydningen av kjønn i vurdering av professor- og dosentkompetanse i kunstfagene [Quality and the influence of gender when assessing professor competense within the arts]. Nordic Journal of Art and Research, 8(1), 1-18. http:// dx.doi.org/10.7577/information.v8i1.2853

Bondestam, F., \& Grip, L. (2015). Fördelning eller förfördelning? Forskningsfinansiering, jämställdhet och genus - en forskningsöversikt. [Research funding, equality and gender - a research overview.] Forskningens villkor 2015(1). Nationella sekretariatet för genusforskning. University of Gothenburg.

Borgström Källén, C. (2014). När musik gör skillnad - genus och genrepraktiker $i$ samspel [When music makes a difference - gender and genre practice in interplay]. [Doctoral dissertation, University of Gothenburg]. https://gupea. ub.gu.se/handle/2077/35723

Borgström Källén, C., \& Lindgren, M. (2017). Performing gender when music is, or is not, at stake - a meta-analysis on students' adaption to discourse. Nordic Network for Research in Music Education, Yearbook 18, 97-116. 
Borgström Källén, C., \& Lindgren, M. (2018). Doing gender beside or in music: Significance of context and discourse in close relationship in the Swedish music classroom. British Journal of Music Education, 35(3), 223-235. https://doi. org/10.1017/So265051717000316

Bourdieu, P. (1986). Kultursociologiska texter [Writings on sociology of culture]. In D. Broady \& M. Palme (Selection). Salamander.

Bourdieu, P. (1988). Homo academicus. Oxford Polity.

Bourdieu, P. (1993). The field of cultural production. Columbia University Press.

Bourdieu, P. (2000). Konstens regler. Det litterära fältets uppkomst och struktur [The rules of art]. Symposion.

Bourdieu, P. (2001). The masculine domination. Polity Press.

Burnard, P., Hofvander Y., \& Söderman, J. (2015). Bourdieu and the sociology of music education. Ashgate.

Butler, J. (1993). Bodies that matter. On the discursive limits of 'sex'. Routledge.

Cattani, G., Ferriani, S., \& Allison, P. D. (2014). Insiders, outsiders and the struggle for consecration in cultural fields: A core-periphery perspective. American Sociological Review, 79(2), 258-281.

Citron, M. (1993). Gender and the musical canon. University of Illinois Press.

Clandinin, D. J. (2007). Handbook of narrative inquiry: Mapping a methodology. Sage.

Connell, R. (2009). Gender in world perspective. Polity Press.

Dahlin-Ivanoff, S. (2018). Fokusgruppsdiskussioner [Focus group discussions]. In G. Ahrne \& P. Svensson (Eds.), Handbok i kvalitativa metoder [Handbook in qualitative methods] (pp. 81-92). Liber AB.

de Boise, S. (2018). Gender inequalities and higher education: comparing the UK and Sweden. British Journal of Music Education, 35(1), 23-41.

De Fina, A., \& Georgakopoulou, A. (2015). The handbook of narrative analysis. Wiley Blackwell.

Dyndahl, P. (2002). Musikk/teknologi/didaktikk. Om digitalisert musikkundervisning dens diskursivitet og (selv) ironi [Music/technology/education. On digitilized music education, its discursivity and (self) irony]. Unipub AS.

Dyndahl, P., Karlsen, S., Nielsen, S. G., \& Skårberg, O. (2017). The academisation of popular music in higher music education: The case of Norway. Music Education Research, 19(4), 438-454. https://doi.org/10.1080/14613808.2016.120428o

Esaiasson, P., Gilljam, M., Oscarsson, H., \& Wängnerud, L. (2012). Metodpraktikan. Konsten att studera samhälle, individ och marknad [Practical methodology. The art of studying society, individual and market]. Nordstedts.

Ferm Almqvist, C. (2019). Towards offering equal learning opportunities for female students in popular music ensemble education: Relate, respond, and re-do. Music Education Research, 21(4), 371-386. https://doi.org/10.1080/14613808.2019.1633293

Frazer, M. (1997). Justice interruptus: Critical reflections on the 'Postsocialist' condition. Routledge. 
Ganetz, H. (2009). Rundgång, genus och populärmusik [Feedback loops, gender and popular music]. Makadam.

Gould, E. (2012). Homosexual subject(ivitie)s in music (education): Deconstructions of the disappeared. Philosophy of Music Education Review, 2o(1), 45-62.

Green, L. (1997). Music, gender and education. Cambridge Univiversity Press.

Griffin, G. (2017). A dictionary of gender studies. Oxford University Press Online Version. https://www-oxfordreference-com.ezproxy.ub.gu.se/view/10.1093/ acref/9780191834837.001.00o1/acref-9780191834837

Husu, L., \& de Cheveigné, S. (2010). Gender and gatekeeping of excellence in research funding: European perspectives. In B. Aulenbacher, E. Kirsch-Auwärter, U. Müller, \& B. Riegraf (Eds.), Gender change in academia. Remapping the fields of work, knowledge, and politics from a gender perspective (pp.43-59). Springer.

Kalm, S. (2019). Om Akademiskt hushållsarbete och dess fördelning [On academic housekeeping and its allocation]. Sociologisk forskning, 56(1), 5-26.

Leonard, M. (2007). Gender in the music industry, rock, discourse and girl power. Ashgate.

Lorentzen, A. H. (2009). Fra syngedame til produsent, Performativitet og musikalsk forfatterskap $i$ det personlige projektstudioet [From singbird to producer.

Performativity and musical authorship in an individual studio project]. [Doctoral dissertation, University of Oslo]. https://openarchive.usn.no/usn-xmlui/ handle/11250/2437870

McClary, S. (1991). Feminine endings: Music, gender and sexuality. University of Minnesota Press.

Nerland, M. (2003). Instrumentalundervisning som kulturell praksis. En diskursorientert studie av hovedinstrumentundervisning i høyere musikkutdanning [Instrumental teaching as cultural practice. A discourse-oriented study of teaching in higher music education]. [Doctoral dissertation]. University of Oslo.

Nylander, E. (2014). Skolning i jazz. Värde, selektion och studiekarriär vid folkhögskolornas musiklinjer [Jazz schooling. Value, selection and music careers in folk high schools] [Doctoral dissertation]. Linköping University.

Pellegrinelli, L. (2008) Separated at 'birth': Singing and the history of jazz. In N. Rustin \& S. Tucker (Eds.), Big ears: Listening for gender in jazz studies (pp. 31-47). Duke University Press.

Stewart, R. (2010). Creating new stories for praxis: navigations, narrations, neonarratives. In E. Barrett \& B. Bolt (Eds.), Practice as research approaches to creative arts enquiry (pp. 123-134). Tauris \& Co.

Wieland Howe, S. (2009). A historical view of women in music education careers. Philosophy of Music Education Review, 17(2), 162-183.

Wych, G. (2012). Gender and instrument associations, stereotypes and stratification, a literature review. National Association for Music Education, 3o(2), 22-31. 


\title{
Experiences and Perceptions of Multiculturality, Diversity, Whiteness and White Privilege in Music Teacher Education in Mid-Norway - Contributions to Excluding Structures
}

\author{
Sunniva Skjøstad Hovde \\ Queen Maud University College
}

\begin{abstract}
This article focuses on how staff in musical teacher education institutions experience and perceive the terms multiculturality, diversity, whiteness and white privilege, and how this might contribute to excluding structures. The author suggests through a post-qualitative rhizomatic analysis some ways through which excluding structures might be maintained, some touchpoints between different fields of practice, and some marginal practices with enough power to create alternative norms. The author also suggests some points of immanence, what can be seen as remaining within (unspoken of) the practices and a list of possible excluding practices and/or possible consequences for the marginalized groups.
\end{abstract}

Keywords: systemic racism, higher music education, teacher education, multiculturality, whiteness

In the report "Culture + School $=$ True" [author's translation] (Berge et al., 2019, p. 186), the authors point out the unbalanced social and cultural representations in Norwegian schools of music and performing arts (NSMPA). There is no information in any language but Norwegian, and

Citation of this chapter: Hovde, S. S. (2021). Experiences and Perceptions of Multiculturality, Diversity, Whiteness and White Privilege in Music Teacher Education in Mid-Norway - Contributions to Excluding Structures. In E. Angelo, J. Knigge, M. Sæther \& W. Waagen (Eds.), Higher Education as Context for Music Pedagogy Research (pp. 269-296). Cappelen Damm Akademisk. https://doi.org/10.23865/noasp.119.ch11 License: CC BY-NC-ND 4.o. 
web information is relied upon to access the local NSMPA. Leaders in NSMPAs also confirm that this is an issue they are working on; this bothers them and is important for them, as they do not fulfil their societal mandate if there is a mismatch between the population's diversity and the demographics in NSMPAs (Kulturskolenettverket, 2019). The Arts Council in Norway has led the project An Inclusive Cultural Sector in the Nordics, which was finalized in 2019. ${ }^{1}$ The departing point here was that the cultural sector in the Nordics has not been inclusive enough, which has resulted in a lack of diversity, which threatens the prerequisite of democracy. The whole cultural sector recruits music directors, musicians, teachers and administrators from the music education institutions in Norway; in Mid-Norway, this means that they are recruiting mainly from higher music education institutions in Mid-Norway, all of which are situated in the Trøndelag region. The author also works at one of these institutions. It has been important to write in a way where as little as possible can be identified to a spesific individual or institution. I have, been leaning on, amongst others, ethical guidelines for humanities and social science, from NESH (2019). Particularly on the issues of respect for individuals, groups and institutions.

These institutions also recruit music teachers for primary, secondary and high schools as well as for higher education. Very little is known regarding the cultural or ethnic backgrounds of teachers in primary and secondary schools in Norway, but it is known that the teachers' backgrounds, educations and acquired knowledge are crucial when it comes to the content and methods used when teaching (Sætre et al., 2016). If structural and formal documents do not really shape what or how a person teaches (Sætre et al., 2016), then it becomes even more important for a student's education to address issues that they might not have experienced in daily life, such as issues regarding diversity and multiculturality.

1 The intention of the project was to supply NSMPAs with "more knowledge on, and insight in, how refugees, asylum seekers, minority language speakers and others with different cultural backgrounds can be included through the communities' art-and cultural offers" (Kulturskolen som inkluderende kraft i lokalsamfunnet [NSMPAs as an inclusive power in local communities], n.d.; author's translation). 
This would also be important to help students understand their privileges and how (lack of) privilege affects us.

This inquiry has a decolonial starting point, as I intend to question the normative structures that might make us contribute to an oppressive/ exclusive cultural representation in music teacher education. The term decolonialism entered Norwegian higher education with strength in 2018 when Studentenes og Akademikernes Internasjonale Hjelpefond (SAIH) published a resolution (Hva mener vi med avkolonisering av høyere utdanning? [What do we mean by Decolonization of Higher Education?]) for the decolonisation of academia. They point out that colonial processes have created oppressive and unbalanced power structures, systems and dynamics which instruct what has been acknowledged as knowledge as well as what is taught and by whom. This is also how I understand why we need to discuss power structures, systems and dynamics in our educational systems.

Since February 2020, when the Black Lives Matter movement reached a worldwide audience, systemic racism has also become an issue of discussion in Norway. At the Oslo National Academy of Arts in Oslo (KHIO), this has already been under discussion for some time (Kifle, 2020). We have not had these discussions openly in Trøndelag, where the institutions of Nord University, Department of Teacher Education at the Norwegian University of Science and Technology (NTNU, ILU), Department of Music at the Norwegian University of Science and Technology $(\mathrm{NTNU}, \mathrm{IM})^{2}$ and Queen Mauds University College are placed. Of the permanent staff, no employee identifies as a person of colour. There is one employee with a Sami background, one with a Vietnamese background, three with northern European (not Norwegian) backgrounds and one with an American background. The total number of employees at the four departments is approximately 65 .

2 The entire department consists of Dance Studies, Music Technology, Musicology and Music Performance Studies, but Dance Studies and Music Technology have not been included in this study as they do not recruit much to the various teaching positions within Norwegian Schools of Music and Performing Arts (NSMPA's) and the regular school system. It should be known that these two sections have many more students and employees with more diverse backgrounds, both intersectional and ethnic. 
Both Kulturskolenettverket (2019) and Berge et al. (2019) point out that if we want to achieve a more correct representation of the population in music education, it has to be done structurally. A more correct representation of the population in employees and students is important for many of those interviewed, though not all. It is not a consensus that diversity is always wanted, or that it is important, but everyone acknowledged the importance of role models.

My aim is to inquire how we, in music education, understand the terms multiculturality, diversity, ${ }^{3}$ whiteness and white privilege. I interviewed three groups and seven individual employees in music education in Trøndelag about their experiences and perceptions of these terms in both their artistic and pedagogical lives, in their research and in their private lives.

My point of departure is that if an all-white group, where almost all individuals identify as Norwegian, is not obliged to address the issues of multiculturality and privilege in their classes, then students will have little experience in discussing whiteness and how white privilege and whiteness in general affect their discourses. If they have not had personal experiences of these matters, then they have heard little about how life, culture and art-making is affected by being marginalised (like many people of colour, muslims or indigenous people in Norway have been), and if experiences and familiarity with terms like multiculturality are scarce, then we will unconsciously reproduce the oppressive and exclusive structures that already are at work.

"Multiculturality" is a term that has been used widely when discussing cultural diversity in Norway, which is why I chose this particular term, since many people would prefer to use the terms "cultural diversity" or just "diversity." Awareness of privilege and (lack thereof) racialised/ marginalising experiences are perspectives many of the participants (of colour or marginalised ethnicities) I have interviewed in other projects like "Global Musicking" (Hovde, 2012) and "A Muslim Afro Joik in Swedish in Norway"4 (Fazlic, 2019) see as crucial to understand, discuss and fight structures and practices which maintain unbalanced cultural

This term has been added as many of the interviewed rather wanted to talk about diversity than multiculturality.

4 A theatre performance I followed and did research/documentation for in the pilot. 
representation in the arts and in education. I am curious whether music educators are aware of their whiteness and I am interested in the privileges and the implications of both situations. Do they consider their own "racialized social location and their [own] status within the racial hierarchy" (Hankins et al., 2012)?

I have therefore carefully chosen the terms "multiculturality" and "whiteness/white privilege" to look at how these terms are treated and understood, how they are part of the praxis and backgrounds in music teacher education in Mid-Norway.

This article is a post-qualitative inquiry; I do not seek representation or an essence, and I do not lean on any qualitative methodology. I seek to de-normalise the norms in the material, in line with how St. Pierre (2020) sees post-qualitative inquiries, and I look at what appears as immanent in the rhizomatic analysis of experiences and perceptions. Like St. Pierre (2020), I lean on the philosophy of immanence, the way Deleuze sees it, as what is remaining within (Deleuze, 2005, p. 252) and, at the same time, as what might hold different energies or directions together (Deleuze, 2005, p. 200). This is relevant when we discuss multiculturality and whiteness/privilege as there are many lines and directions, but there are still powers that keep the lines together and powers which enable flight from the established order. I will say something about what I see as taken for granted, immanent and steadfast. I am interested in what the experiences and perceptions of the terms "multiculturality" and "whiteness" do not address, what they take for granted as immanent in the established rhizome of music education, and what is working to destabilise what is remaining within this understanding. This inquiry gives us examples of what is created as central and peripheral, what is immanent and what is marginalised when discussing multiculturality, diversity and whiteness/ white privilege.

Informed by the points mentioned above, my analytical question is: How do music-teacher educators in Trøndelag experience and perceive practices, values and significance related to the terms multiculturality and whiteness/white privilege, and how does this contribute to a reproduction of oppressive/exclusive structures through de-territorialising and re-territorialising existing relations and structures of power? 


\section{Theory}

\section{Multiculturality}

Multiculturality, as a term, has status as the subject of this inquiry - I look at how music educators re-territorialise and de-territorialise the term through how they position themselves towards and against established perceptions and practices. I also use different definitions of multiculturality to analyse experiences and perceptions of the term in the material. Multiculturality, and variations of the term, is commonly used in curricula and policy work to describe "societies, objects, individuals or ways of thinking where a variety of cultural co-understanding are represented within the same unity" (Rønningen, 2015, p. 24; translation by the author). Rønningen points out that the term works as an empty stereotype of difference if it is not followed by more precise and informative material. This is what I want music educators to add.

Matarasso $(2013,2019)$ understands multiculturality in the same way as other types of diversity, e.g. biological diversity. We seem to agree that we need biological diversity to survive on this planet, where all living creatures together produce diversity. If we look at cultural diversity the same way, it would be not only the marginal musical practice's that produce diversity but also the dominant practice; hence, we are all part of the diversity (Matarasso, 2013). In this regard, we could say, from the report "Culture + School = True" (Berge et al., 2019), that there is an overrepresentation of one part of the population's diversity in music education and in NSMPAs.

Teachers' lack of competence in the area of multiculturality might contribute to the invisibility of students with immigrant backgrounds, as the teachers would not be trained to see diversity potentials (Skrefsrud \& Østberg, 2015). The difference in how teachers understand multiculturality, as a problem or as a resource, also affects the process of stereotyping (Hauge, 2014). This is a pivotal point in why I use the perception and experiences of multiculturality as a means to look at power. How music educators understand multiculturality gives them the power to define and legitimise, de-territorialise and re-territorialise norms e.g. stereotypes. Lund (2018) emphasises the importance of a structural competence 
on these issues. They found that employees at schools where the multicultural perspective was outsourced to one or two specific teachers, were significantly more insecure on how to use educational and sociocultural tools to strengthen marginalized students.

Kallio and Westerlund state the importance of challenging cultural, musical and educational comfort zones in the work of reconstructing music educational perspectives. This is uncomfortable, but they see this as highly necessary, as these experiences touch upon "the art of living with difference" (Kallio \& Westerlund, 2020, p. 47) if one is to understand a world of difference. This acts as a subway to arrive at the issues of whiteness and white privilege in this article.

The term multiculturality and how it was discussed was criticised on several occasions through the interviews. Bringing in transculturality as a way of nuancing was done as one participant experienced multiculturality as "wobbly" and empty: "We integrate perspectives from a wide diversity of music cultures in ourselves!" (interviewee's translation). Another participant emphasised the emptiness of the term but also found it difficult to use any other word. The term was also criticised for overly focusing on background, geography, origin and the parents' culture.

\section{Whiteness/White Privilege}

How white bodies understand themselves is relevant in this project, as white privilege both facilitates power to white bodies and marginalises the relevance of discussing race in shaping social outcomes (Hankins et al., 2012). NSMPAs are an educational praxis, a physical and artistic space that racializes through an unbalanced representation.

Keinz and Lewicki (2019) point to how the European body is wanted, legitimate and standard, associated with whiteness, secularity, acceptable class/gender dynamics and systems, and beauty. These privileges are not immediately visible for the ones possessing them, but they seep through every pore in the lives of the ones not holding them.

This is why I have been asking about whiteness/white privilege. Lacking an awareness of whiteness/white privilege encourages stereotyping, as pointed out by Hauge's (2014) discussion of multiculturality. The issue 
of whiteness or privilege is treated in this article as a way of looking at music educators' awareness of themselves in a multicultural context and their knowledge of how their white (and other) privilege(s) influence both them and their students.

\section{De-territorialisation and Re-territorialisation}

I connect what Hauge says about stereotyping to Deleuze and Guattary (2005) and their way of looking at how something becomes true over and over and over again through re-territorialising the established. Reterritorialisation is a process of becoming what is already there, again and again; it is reproducing what is already established. De-territorialisation, on the other hand, is a process of becoming something else, where new energies form and affect the environment. With de-territorialisation, new becomings 5 are happening, and the rhizome is taken to the periphery of what it is (Deleuze, 2005, p. 69-71). A de-territorialisation will have consequences for the collective, and re-territorialisation affects the individual rather than the collective, as it legitimises what the environment has adjusted to over time. They work together and are not to be seen as dichotomies (Hovde, 2012).

The material deals with many areas of musicianship, music pedagogy and music teaching, e.g. professionalism. An example of de-territorialisation and re-territorialisation is how talking about multiculturality opens up the way the interviewees are becoming artists and pedagogues through their own definitions and positionings. One talked about how pedagogues use music as a tool for subtle everyday joy and positioned artists as the ones going into the deep dark of our emotional range; the participant is, through this, making himself part of the process of being an artist, and because he is a music pedagogue through his practice of teaching music, he is also attempting to de-territorialise the practice of music pedagogues. He is not, as I see it, succeeding, because he described his own practices as "without companionship" in his institution. He also

5 "Becomings" is a term from Deleuze and Guattari (2005), deriving from the French word devenir, and it refers to the way they look at how something is becoming something, and not how something is. 
added that it would be different in other institutions, where more people would feel the same as him. His part in both re-territorialising his own identity as a musician and not as a pedagogue plus de-territorialising the music pedagogue is typical of these processes. They happen at the same time, and often about the same, but with different directions and power.

\section{Rhizomatic Analysis and the Lines of Flight}

A rhizomatic analysis focuses on the diversity of entrances, crossroads and exits along the many lines produced by actors in the rhizome. A rhizomatic understanding of the world implies that one does not look at the intention, but the practice; it is how one observes movements and becomings more than what "is" (Hovde, 2012, p. 26). A biological rhizome is a fungus root structure with many or no source of creation, no start or end, and multiple meeting points where the lines of the rhizome cross each other or touch each other - touching points. If I create a rhizome of the utterances from the music educators I have interviewed, the perceptions that are seen as immanent or remaining within the norm, will form clusters of energy; they will re-territorialise the rhizome that has been legitimised over and over again. The borders of the rhizome of utterances will be determined by the energies keeping it together, re-territorialising it (Deleuze, 2005, p. 29). The de-territorialising perceptions of the term multiculturality would, if they have enough energy and momentum, form lines of flight to shape new rhizomes on their own (Hovde, 2012).

\section{Power}

Lindgren claims that education, including NSMPAs, pretends to be a tool that everyone can use to enter any discourse. In any case, the educational system is political, which means that it is a particular conformation or change of discourses and knowledge, and thus power. Power is always present and always produces hierarchies of values (Lindgren, 2006, p. 51).

Lindgren is not concerned with formal power, but that formal power hides in structures of power where social relations and informal praxis are organised and regulated. This is relevant in light of NSMPAs, as 
formalities exist, but the praxis's values and hierarchies are still working as they did before. I dive into those informal power structures connected to how we understand specific terms and how we value them.

Power is a lens of analysis in this article, as I see re-territorialisation and de-territorialisation as means of power. Through re-territorialisation, we give power to the collective, or the established practices, while de-territorialisation has consequences for the established, and for the community, but gives power to the marginalised.

\section{Who is Asked and What is Asked?}

As St. Pierre wrote, "post qualitative inquiry begins not with a social science research methodology, but with a philosophy of immanence" (2020, p. 2). Later, I explain how I perform the analysis, which is not so much a methodology, but transparency in how I treated the material.

The two main questions I ask in the interviews are:

- What does it mean for you to be white, in your musical praxis, your teaching or research? Have you received any advantages or disadvantages because of this? ${ }^{6}$

- What has the term, or the praxis associated with the term, multiculturality meant for you in your studies, your musical background, or your present teaching and research?

These questions are different from each other in terms of what material they generate. The first is operationalised by me, and I am not asking about their opinions or perceptions of the term, but merely about how they have experienced what I define as whiteness or white privilege. The term in the second prompt must be interpreted by the interviewee.

The empirical material in the article comes from four musical education institutions in Mid-Norway, which recruit music teachers for all

6 It was not necessary to phrase this differently, as all interviewees identified as white, which includes nationalities within Northern Europe. The Sami identity has been discussed when using the term "white," as it might point to "Norwegian" in this context, but this is not a discussion in this article, as it is related to the methodology, which is questioned in another article. 
levels of music education. Altogether, 20 persons were involved in these interviews. Some of the interviews were done in groups, and some participants requested individual interviews. The individual interviews were done mostly for logistical reasons, but some also expressed the wish to do a separate interview because they did not feel comfortable talking about this in a group of colleagues. One individual declined to be interviewed for the same reasons.

\section{What is Told: Strata of Themes}

I looked at how participants' utterances positioned some things at the margins and some things at the centre, and I observed what was taken for granted, not spoken but immanent, in their utterances. Did they position themselves in opposition to something specific? Were the utterances part of a de-territorialisation process or a re-territorialisation process? Were they returning power to the established or were they challenging it, and with which arguments and reasonings?

I thematically sorted the material, but I have not reduced the material, as that would be a step into a qualitative methodology that I do not use here. This is only done as a first step of analysis to more clearly see which areas the power is dealing with; in other words, the areas which seemed to be important for the interviewees. These thematic areas were "musical backgrounds," "professionality" and "whiteness and black music". These themes are strata of material that were overlaid to identify lines of flight indicating energetic but de-territorialising thoughts to see where many threads touch each other, suggesting a connection (touching points). A touching point is a place where the different themes have experiences and perspectives in common, where the material comes together and keeps itself together in a tight rhizomatic structure. This is not a reduction to see what is "most common" or a generalisation, but rather a way of looking at where the material connects in the context of the strata of themes. An example of this is a type of "us-versus-them-thinking," where "multicultural" is conceptualised as someone outside of the self - as refugees, as students who want to play a genre of music that is not offered, as someone from another 
country, as someone participating in Fargespill, ${ }^{7}$ as someone who is different from them or the institution or as someone who doesn't fit in or has to be helped to fit in; in these situations, the "other" often does not speak the language well.

At the end of the analysis, I look at how power through de-territorialisation and re-territorialisation is expressed in these touching points and in the solitary lines of flight. I also look at what could have been, but was not, said, which corresponds with Elisabeth St. Pierre's (2020, p. 1) outline of post-qualitative inquiries.

\section{Assessment Practices, Curricula and Administrative Decisions}

There are differences in how curricula, assessment practices and administrative decisions are given power; some interviewees mentioned these as significant barriers to diversity or as contributing to oppressive or exclusive structures. The educators saw these documents' powers differently, and when it came to assessment practices, only the ones unhappy with the praxes mentioned them. This was the one area with a clearly expressed dichotomy between art music traditions and less notationoriented traditions.

The responsibility for a lack of diversity was partially attributed to a lack of money: "If we could use money freely and hire different competencies and varied backgrounds, ${ }^{8}$ it would colour our programs." The language, and the power, of policy documents was problematised and connected to the narrated dichotomy between pedagogues and artists: "When we write these documents, there is no space for the language of art. There isn't room for anything else but non-feelings. This opens up the possibility to teach without feelings because it does not say you have to."

7 While Fargespill (A project where young artists play with professional musicians, emphasizing the young artists multicultural backgrounds, in different ways. The word "farge" means "color", "spill" might be translated with "play" as in "playing music, or/and "play" as in how a diversity of colors can be reflected/play on a wall, in trees, in the water or the rainbow. https://fargespill.no/) is open to students both with Norwegian and with other cultural backgrounds, in these interviews, it was clear that Fargespill was repeatedly viewed as the arena for the "multicultural" child.

8 Different from the dominant group of employees at the institution. 
Assessment practices are significant in defining legitimate knowledge and are seen by some as a strong contributor to the unbalanced representation since the notation praxis from Western art music seems to be a norm when submitting musical assessments. Some see this as a marginal praxis globally, and some present the privilege of coming from a Western classical tradition as discriminating. They also state that this was driven by the NSMPA's conservative demand for teachers, "as they preferably hire someone from the same background as the mainstream teacher in the NSMPAs: the classically schooled." Other participants stated that the students have to be evaluated on something and that they have to leave the institution with some measured knowledge.

At a group interview, one of these institutions compared the challenges with culturally diverse students with problems they faced when adjusting assessments and exams for a visually impaired student. These two examples of marginalisation were put in the same bag. This can be seen as a way of exercising a problem-oriented diversity perspective (Hauge, 2014); when someone is different from the expected norm, where a form of "colour blindness" is employed (Skrefsrud \& Østberg, 2015). Hankins et al. see this as a result of whiteness, as this privilege might contribute to the ability of marginalising the relevance of race, in shaping outcomes (2019).

The tension between musician-professionality and pedagogy-professionality comes to the surface also within these formalities. The more artistic-oriented perspective is presented as marginalised because it associates the body with feelings and the "real flesh-and-blood world" and it is marginalised when it comes to assessment practices, because it is not measurable and because it is scary "for the white non-emotional so-called rational pedagogy"; this is similar to how Keinz and Lewicki (2019) discuss white European bodies and how Western art music has been presented as civilised, non-racialised, without context and universal (DeNora, 1997; Mcclary, 2002).

\section{Musical Backgrounds, Practices and Epistemologies}

Many interviewees point to one specific music researcher in the region as pivotal in the formation of multicultural competence. He was described 
as someone who challenged and annoyed his colleagues by always questioning the paradigms of Western art music and Western-oriented music philosophy. By pulling his colleagues out of their comfort zones, like Kallio and Westerlund (2020) described, he was seen as a force that moved students into unknown musical and pedagogical grounds. He is, by putting the students in these situations, giving them an opportunity to surrender to a de-territorialisation of the existing syllabus.

Some went on study trips outside of Europe and mentioned these as experiences crucial to the musical and pedagogical choices made later in life and to how they look at cultural heritage and global multiculturality because they accessed repertoires, philosophies and ways of teaching different from West-European genres. One explained the pivotal point of understanding that different cultures have different logics and "can't be measured through 'my' judgement on what is a good life", which came while travelling. The participant experienced that when he went from walking the streets and taking in what he saw as a poor way of living to entering a small rehearsal studio, a known environment where everyone turned into musicians. He simply understood very deeply that he had no possible way of having an opinion about their lives, as they all played on equal terms; they ate together, and they travelled together. This experience was explained as a concrete reason for a strong belief in cultural meetings - real cultural meetings, "as it makes you understand music as part of us and our context." This example shows how the interviewee went through a process of re-territorialising his own values while travelling, and then, through musical practice, suddenly had a deep feeling that this diversity had nothing to do with his norm, because "I come from a very different and in many senses very privileged place," so he could not understand or evaluate this other reality.

"Everyone talked about their education being Western-based, some more than others: "There were no other cultures where I grew up. It was a marching band and NSMPA. And I played alone. It was two different kinds of music. One was at the NSMPA, where the art-music way of teaching "right or wrong ways of doing something" was dominant, and the other kind of music was done on the side, improvising, joking, making music and being playful." (Interviewee) 
The widespread homogeneity in musical background is interesting, as very few question it; it seems to be the most normative force in the whole material.

Unity through repertoire from Norwegian traditional music was thematised as important by some music educators, and during my analysis, this became evident in a few interviews. This kind of repertoire was described as something they expect the students to know, and instructors do not usually have to argue for its inclusion in the curricula. It was described as something that used to be taken for granted, and many expressed surprise and disappointment that it is no longer part of the norm. It is not still immanent in the repertoire of what should be learned, and as such is not part of the existing rhizome. The traditional Norwegian repertoire seems to have lost its power as relevant for the students, which is both frustrating and surprising for the teachers.

A few interviewees spoke of multiculturality as diversity at home, in a class, in society or within a community, and they talked about it in opposition to what they viewed as the mainstream perspective. Another way of talking about multiculturality is as part of strictly musical situations, where the "multicultural musician" is positioned as "the other." In both of these cases, it is immanent that multiculturality is seen by society as "the other" even though the individuals interviewed have diverging opinions about what it actually is. One participant defined multiculturality as "the total of all variations of cultural expressions in a group or local society," very much in line with Matarasso (2013), and did not position himself either within or outside the norm.

One stressed the need to teach students not to reproduce their teachers. He sought a de-territorialising direction within the student's repertoire, technique or genre, and his way of looking at diversity in students' lives as a resource makes me think about Østern and Hovde's (2019) way of seeing life as artistic material as something inseparable from music.

To start "in the Music itself" (not in theory, history or pedagogy) is a perspective many talk about as a way of opening up to diversity and avoiding privileges, "because we improvise and we teach them to say yes to everything that comes." "The music" is also seen as more available to everyone if the starting point is in a groove. This belief in the groove was 
conveyed as progressive rather than as part of the established order. At the same time, it was not questioned, and it remained within the explanations that it is a positive force in education.

\section{Profession: Artist and Pedagogue?}

There are significant differences in how the interviewed participants defined their professional identities. One identity was that of a music pedagogue, and "musician" was another. No participant ascribed much weight to "research profession" in their examples.

Music pedagogy was described as something that should equip all students with the ability to differentiate and facilitate any marginalisation but without necessarily being trained in specific knowledge for different marginalisations. Music pedagogy has also been called an exclusive, "Norwegian" and "white" praxis which fuels unbalanced representations and does not consider marginalised people's needs. This interviewee feels that particularly marginalised, excluded or vulnerable people need a place to put their emotional material, as it is an emotional burden to be outside. Another participant also mentioned what he saw as the need that marginalised youth have to express themselves. "They want to do hiphop because they feel the need to express themselves; I entered hip-hop because I loved the grooves and all the buttons and knobs to turn on. I wish they also worked here."

One participant pointed at the importance of multiculturality being represented by "people from foreign cultures." This perspective of multiculturality as a representation of "people from foreign cultures" is exclusive. For example, young people of colour, might understand themselves as Norwegian, even though they might be seen as "multicultural" or "representative of foreign cultures" by white Norwegians. This is also a perspective which focuses on multiculturality as something that needs to be taken care of by "particularly invited ethnic musicians" (Rønningen, 2015). A more performative way of seeing music education was also presented:

To play a note written on a piece of paper is easy. Super easy! But if you are to put anything at risk and offer something, you'll ask what they are interested in, what they play with. Maybe it is a dog! «Dog! Awesome!» Improvise the dog 
on the couch with them, and maybe do some notation in the process. It might become a composition, because we record it or film it. It becomes a product without us forcing it to be a product, and it has been an eye opener for many of my students when it comes to how you can teach music. Through playing! (in Norwegian "leke") (Interviewee)

This way of seeing teaching has a strong energy which differs substantially from other views due to this way of seeing a child as resource. $\mathrm{He}$ explained that this comes from an improvisational perspective. The instructor must find entrances in the student that resonate with the student which give the teacher a reason to play with the student for real and not simply for practice. This is a performative way of teaching that lets the student become himself musically again and again, but the teacher lets it happen and evolve again and again. The teacher also changes his position so that the student can always take the initiative. This is a strong de-territorialising process where a student becomes something new from moment to moment.

\section{Whiteness and Black Music (racialised moments)}

When talking about whiteness and white privilege in relation to their backgrounds, practices and musical everyday life was new to many of the interviewees, which resulted in a wide variety of responses. Whiteness was connected to Norwegianness and white male guitarists (a stereotype in many popular music genres, including modern jazz), to limitations and to a fear of stepping into something wrong. Many talked about their connections to "black music" and how it is difficult for them to see themselves as white, musically, since they identify as mainly interested in jazz, soul, disco, blues or funk. Some mentioned that these genres have been developing a lot and maybe should not be considered "black" anymore: "Isn't this music just for everyone now?" This was mentioned in the conversation about whiteness. It was also noted that playing "black" music was seen, by some, as something which made them feel less attached to whiteness or white privilege. This seems to be a way of taking ownership of a cultural heritage which originated from African American and African people, who paid for this with much pain, and many still do. 
Solving racialisation by appropriating music is part of what white privilege can do: marginalising the importance of race, ethnicity or cultural belonging (Hankins et al., 2012).

When speaking about teaching students the music but without talking much about present privileges, diversities or marginalisation, one interviewee commented, "When we are a bunch of white people saying we are interested in black music, we are not interested the same way as we would if we had felt the context, the marginalization. We love the music, but we don't necessarily have the context, or want the context, or are interested in communicating the context, which is pain. But we do not want to deal with this."

Norwegianess is equated by some to whiteness, and the students' lack of competence in Norwegian folk music came from talking about whiteness, which left me with the impression that talking about whiteness was new and somehow uncomfortable, and that the closest thing to whiteness to talk about in such a situation was what intuitively popped up as white: traditional Norwegian music, which was seen as underrepresented. "It's almost like you have to fight to include some Norwegian culture," and "the students don't even know Millom Bakkar og Berg".

The question about whiteness made one participant think about the music he was growing up with and is now playing: "It is kind of in my blood. From the neighbour and the generations before us." The local culture and dance music is a big part of me, both professionally as a musician and in my family." This local culture was also narrated as uninteresting, underrated and hillbilly-associated. This was the only answer to how whiteness had been important, whether anyone had felt whiteness or white privilege through their music practices.

Norwegianess and whiteness were also connected to working-class morals: "Things were supposed to be done properly, not halfway [det skulle ikke slaskes til]." Civilised behaviour and decency are two parameters Keinz and Lewicki describe as connected to European white bodies, in

9 This is an answer that privately could have made me uncomfortable, as it turns the question from being about exclusion and discrimination of people with marginalised background into a victimisation of Norwegian culture and equates Norwegian culture with Norwegian folk music. It is, though, critical that all interviewees viewpoints are valued equally. 
opposition to "carelessness," which is related to presumptive Arabic and African bodies (Keinz \& Lewicki, 2019). In other homes, there were "people from different countries discussing many issues from many places. I experienced it as diversity because they didn't agree. I had Sami culture close as well, but it wasn't pointed out as it was shamed at that time. Which annoys me today." Norwegianess was also described as punctual in opposition to one of the Norwegian minorities and that this was challenging for the teacher, as punctuality was considered a Norwegian trait.

Whiteness was described as, effectively, limiting integrity in some fields as well as limiting the possibilities of what can be discussed in the classroom. The fear of talking about a marginalised population that a teacher is not part of, as when discussing racism, discrimination of Muslims or people with physical disabilities, resulted in a focus on rather general aspects of inclusion and exclusion because it made it easier to avoid any "salads you can step in" and to say something individuals in those groups would see as wrong, offending or directly discriminating.

\section{Touchingpoints and Lines of Flight}

The thematic stratas I have been laying out have points of contact where they touch upon each other, regardless of time, geography, culture, etc.: touchpoints. There are also some commonalities in how energies that goes in other directions but the established, is taking shape: Lines of flight. A line of flight refers to energies in the periphery of a rhizome that are strong enough to create their own entity and to be pronounced as different. A touching point is a point where different lines within the rhizome touch each other. They can be far from each other geographically, historically and philosophically and still have something in common for them to touch upon.

\section{Solitary Line of Flight 1: Performative Understanding of Multiculturality and Whiteness}

This solitary line of flight popped up in several places, and is present, in different ways, in all the institutions, but continuously told as a solitary 
project. The music educators that share something in this line are very clear about their perspectives, and it means something to them. They talk about conflicts because of it, and they talk about not feeling at home in the institutions' dominant perspectives, whatever they may be (as this differs from institution to institution). Multiculturality or whiteness is, within this line of flight, seen as part of the individuals' complex backgrounds, as one of many variations of expressed diversity. In someone's performative musical practice, it is seen as necessary for a teacher to have an open, broad and diverse understanding of what music can be, dependent on the student's resources and interests, to understand what kind of diversity potential is present in a group or a classroom.

This perspective understands multiculturality as a resource and suggests a problematisation of how competence and knowledge are measured and of hierarchical perceptions of musical expressions. All artistic expressions are seen as subjective, and the focus is not product-oriented but exploration. Whiteness and privileges are not important in these perspectives and experiences, even though it is seen as very important that the teachers understand their power and position. To co-create on equal terms is essential in this perspective. I see this as an overall process of de-territorialisation towards granting more power to the student, but not necessarily power towards identity politics. Some of the music educators who touched this line of a performative understanding of multiculturality and whiteness emphasised the value of music as a place where people can express every part of themselves, including the parts not previously reflected upon but which are still embodied in the self. They see ethnicity as part of life, life as part of music, or music as part of life. Some see all contexts as disturbing, and that equality is embedded in the practice of music itself. I come back to this in the touching point titled Music is on equal terms.

\section{Touchpoint: Colour-Blindness}

A specific type of "colour-blindness" comes up in different places, for example, when some music educators said that they are colour-blind, meaning that they do not really notice someone's skin complexion or 
ethnic markers. "We are all multicultural" is a phrase connected to this touching point. As it is also the belief that we can all, no matter what, play on equal terms. The latter is a way of ignoring privilege and being able to, through your own privilege, marginalise the significance of privilege. This was also touched upon when one of the interviewees problematised the whole idea of diversity: "Is it actually that important that everyone and everything is represented? Do we not merely as humans represent each other?" This fuels the problems posited by Skrefsrud and Østberg (2015), that the lack of training in seeing diversity potential causes bearers of multiculturality to be invisible.

\section{Touchpoint: Fear of Misstepping}

In this touchpoints, there are different versions of fear of failed step. Some would avoid covering issues of marginalisation or would leave this task for someone with a different background, either in the classroom or in the staff. The practical solutions were many; some included representatives or people with knowledge about the subject in their classroom, physical resources or digital resources. Some avoided the topic and asked the students to cover it themselves. Some used students, if they were available and willing, to talk about personal diversity perspectives, and some covered it up by talking about general inclusion and exclusion.

Sami culture was discussed as a Norwegian multiculturality with formal power via policy documents but not taught without problematisation, except from an institution with Sami staff. Other places chose to play old, archived examples to hear "traditional" Sami joik or focused on popular music with Sami musicians or material as a bridge to something they feel that they can talk about.

\section{Touchpoint: "The Music Pedagogue"}

This perspective was communicated as a focus on craftsmanship, a measurable product of teaching and the teacher's musical tradition, and was criticised both for being of little interest and for not pushing teachers out of their comfort zones, as Kallio and Westerlund emphasise as a critical 
element for rethinking music pedagogy in the direction of "the art of living with difference" (2020, p. 47). I see this touching point as a strong process of re-territorialisation of what has become the pedagogical tradition over recent years. The touching point is not positioned against the established when talking about pedagogy; rather, it is told as the dominant perspective, but when talking about musical traditions there are great differences, and some saw themselves as outsiders musically, even though they felt at home in the dominant pedagogical understanding.

\section{Touchpoint: Music is on Equal Terms}

In the line of flight concerning performativity, it was mentioned that some people would resist any contextual focus when teaching music. This touching point loosely follows the separation of musician-professionality from pedagogue-professionality. The touching point diverges from the performative line of flight, as "the multicultural" in this perspective is recognised as implicit in the musical repertoire and not necessarily connected to the individual involved. By participating in music, the people playing together are positioned as equal, and they see a focus on a specific marginalisation as disturbing, as they play the music, not the life nor its context. In this touching point, there is also an element of resistance to talk about marginalisation or structural racism, meaning that this should be left to those with specific knowledge about it. Here, it also seems to be a separation between "us" and "them" - groups are seen as different since they come from different musical cultures. I see this in relation to Hauge's way of seeing privilege: it gives you the opportunity to marginalise the significance of it (2014).

\section{Immanence}

I see a significant variation in how the participants saw themselves as white and as carriers of white privilege through the analysis. Some had never discussed this and found it extremely challenging because they were afraid of saying something that others, e.g. students, peers, would feel was wrong, of feeling stupid or feeling provoked. There were also several immanent perceptions expressed in the material. 
The first relates to musical background, as everyone interviewed took it for granted that the common background which qualifies a person for music education or music teacher education is achieved through NSMPAs and/or a music programme at "videregående" (upper secondary school) and "folkehøgskole 10 " (folk high school) and the norm was discussed as Western classical music. A divergence from this path was described as "having a different background." This is also the case for both assessment practices and teaching methods in participants' institutions today. At the same time, genres labelled "African-American" were significant for most of the teachers. This is interesting, as it is a discrepancy between the experienced hierarchy, assessment practices and what kind of music they connect with. It is also interesting that NSMPAs are themselves seen as a conservative force, fuelling a re-territorialising process in higher education, and that reproducing NSMPA structures is closely linked to what music education institutions aim to fulfil.

The second immanence is due to what I would describe as an abyss between the terms "multicultural" and "Norwegian." This does not mean that all the interviewees expressed their own views like this, but that the collective discussion implied that "multiculturality" and "Norwegian" do not overlap. This is remarkable because quite a few defined themselves as multicultural or as playing music which positions themselves in "musical multiculturality" or expressed strong opinions on the matter in opposition to what they saw as an ignorant norm on the issue. This practice, where multiculturality is segregated from the majority (in this case, being Norwegian), opposes how Matarasso (2013) describes diversity and how the author of this article defines diversity. This has made me think that the weight many participants ascribed to travelling outside of Europe to change their perceptions of music and of the world, where they experienced themselves as white and privileged, was not reconnected to their everyday lives. I am left with the impression that many of these music educators have no experience of living in a multicultural society in Norway, and that

109 months program with the aim of formation, not education, where you get to practice what you learn, without any grades, no rigid curriculum and exams (folkehogskole.no, 2020). Many music students have followed music program from upper secondary school and/or music program at a folk high school. 
is maybe also why many connected "multicultural" with someone outside their lives and why they exoticized "multicultural" persons, making them tokens or representations of something. One participant suggested in an interview that her improvisational competence might be an opening to connect improvisation teaching and inclusive thinking in a teaching situation, but this has never appeared as relevant before in the teaching practice, as the issue of inclusive education had never been discussed.

A third immanence was that multiculturality or marginalisation should be dealt with individually. None of the institutions had strategies for being more inclusive and for preventing exclusive and oppressive structures, as the University of Michigan does through their "Inclusive Teaching Initiative" which provides teachers with tools to deal with individual privileges (Inclusive Teaching Initiative, 2020). Berge et al. (2019) pointed out that it must be structures which take care of this, so that it would not be legitimate to be unaware of this field. Very few seem to be pushed out of their comfort zones by their leaders or their colleagues on these issues. This is pointed out as crucial for rethinking music pedagogy in the direction of "the art of living with difference" (Kallio \& Westerlund, 2020, p. 47). Marginalisation was also expected to be handled individually by the marginalised, e.g. through music. To expect marginalised people to need to express themselves more than majoritarian ones, like some music educators in the material do, is at first sight quite exoticizing, but when considering what privilege does to an individual, maybe it is not. The privileged will experience no lack of possibilities to express themselves, while it is part of marginalisation to lack spaces to be seen, expressed and acknowledged. Perhaps the mistake is to expect all individuals connected to "multiculturality" to feel marginalised.

\section{How do we Exclude, and Can we do Anything About it?}

There are a couple of situations worth looking at closely while discussing how we support oppressive and discriminative structures: When someone, without being criticised for it, compares visually disabled and racist structures/cultural discrimination, it gives a strong impression that there 
is a huge lack of awareness of privilege, sensitivity towards marginalisation and knowledge about marginalisation. This is a driving force for unconscious racism, as there is a lack of knowledge about white privilege and about specific marginalisations. To consistently see bearers of multiculturality as something different from "Norwegian" is also a driving force for unconscious racism, as it will always question someone's identity based on complexion, ethnicity, religious markers, etc.

The performative line of flight is one of the clear de-territorialising processes, and maybe one of the strongest alternatives to the two touching points of colour-blindness and "music on equal terms," as the colour-blind perspective in particular is generally re-territorialising in its practice and has many examples of practices, experiences and perceptions that prevent us from being more inclusive. Here are some examples of how we exclude:

- Not mentioning specific marginalisations, which makes marginalised persons feel as though their problems do not exist;

- Expecting music ("if we start in the music, we are all equal") to be neutral, which marginalises the relevance of skin complexion and ethnicity;

- Comparing and equating the marginalisation of Norwegian folk music with non-representation of people of colour or other marginalised groups in Norway;

- Not initiating strategies at the department level or the section level to include guidelines for every person to rectify marginalisation, not simply to leave marginalisation to those who specialise in it or who have personal experiences with a particular marginalisation;

- Not teaching marginalisation out of fear of misstepping (educating yourself and asking for advice are also options);

- Exoticizing multicultural backgrounds and labelling them as "different," as continuously looking at multiculturality as something "foreign" that excludes you from being Norwegian;

- Focusing on scholarly achieved competence, e.g. competence to write music, to get into the education is an exclusive and possibly discriminative structure, as this greatly favours those within a specific genre and implies that this is a skill that all teachers must know, 
even before entering the school (so that if someone comes from a production culture, such as hip-hop, then they will lack privilege if they try to get into an educational institution to formalise their musical competence); and

- Being afraid of stepping wrong and not daring to confront or present opinions out of a fear of someone else disagreeing with these opinions - if a person does not know what they mean or who they are, then they cannot include others, and, as such, they sustain an exclusive culture.

There were more structures in education which sustain exclusivity than I could predict. There is a severe lack of knowledge of white privilege and of the experience of marginalisation. There are also some perceptions of multiculturality which prevent people from feeling acknowledged at institutions, in different forms and on different levels. But there are also de-territorialising initiatives that challenge these problems. Even though they are not the established perspectives, they are present in many shapes and versions. None of these practices are impossible, or even difficult to adjust, upgrade knowledge or change practices for. But it needs to be wanted or secured through central strategies to be changed; if not, it will be up to the individual to take responsibility, read up, ask and discuss.

It looks like the process of discussing these issues has started in all institutions, but many estimate something exceeding 20 years for any structural changes to occur. This perspective suggests that they see a near future where they deliberately continue to reproduce structures that support unbalanced cultural representation in music education. Still, it is a new process for many institutions, and a discussion has started with the aim of rethinking our music pedagogical perspectives if we are to support a more balanced representation in the future.

\section{References}

Barad, K. (2007). Meeting the universe halfway: Quantum physics and the entanglement of matter and meaning. Duke University Press.

Berge, O., Angelo, E., Heian, M., \& Emstad, A. B. (2019). Kultur+Skole=Sant. Kunnskapsgrunnlag om kulturskolen $i$ Norge [Culture + Schoole $=$ True. 
Knowledgebasis on Norwegian Schools of Music and Performing Arts] (TF No. 489). Telemarksforskning \& Utdanningsdirektoratet.

Deleuze, G. (2005). Tusind plateauer: Kapitalisme og skizofreni [A Thousand Plateaus. On Kapitalisme and Schizofrenia]. Det Kongelige Danske Kunstakademis Billedkunstskoler. København

DeNora, T. (1997). Beethoven and the construction of genius. https://www.ucpress. edu/book/9780520211582/beethoven-and-the-construction-of-genius

Fazlic, I. (2019). En Muslimsk Afro-Joik på Svensk i Norge [A Muslim Afro-Joik in Swedish in Norway]. https://festspillnn.no/nb/program/2019/en-muslimsk-afrojoik-p\% $\mathrm{C}_{3} \% \mathrm{~A}_{5}$-svensk-i-norge-no

Hankins, K. B., Cochran, R., \& Derickson, K. D. (2012). Making space, making race: Reconstituting white privilege in Buckhead, Atlanta. Social and Cultural Geography, 13(4), 379-397. https://doi.org/10.1080/14649365.2012.688851

Hauge, A. M. (2014). Den felleskulturelle skolen. Universitetsforlaget.

Hovde, S. S. (2012). Global Musicking; Innvandring og den farlige forskjelligheten [Global Musicking; Immigration and the dangerous difference]. [Doctoral dissertation. Norwegian University of Science and Technology.] https://ntnuopen. ntnu.no/ntnu-xmlui/handle/11250/243652.

Inclusive Teaching Initiative. (2020). An Instructor's guide to understanding privilege. University of Michigan. https://sites.lsa.umich.edu/inclusive-teaching/inclusiveclassrooms/an-instructors-guide-to-understanding-privilege/

Kallio, A. A., \& Westerlund, H. (2020). The discomfort of intercultural learning in music teacher education. In H. Westerlund, S. Karlsen, \& H. Partti (Eds.), Visions for intercultural music teacher education (pp. 47-61). Springer International Publishing. https://doi.org/10.1007/978-3-030-21029-8_4

Keinz, A., \& Lewicki, P. (2019). European bodies. Anthropological Journal of European Cultures, 28(1), 7-24. https://doi.org/10.3167/ajec.2019.280104

Kifle, M. (2020, July 8). KHIO-studenter krever 'avkolonisering' av pensum [KHIO-students demands 'decolonization' of syllabus]. Aftenposten. https://www. aftenposten.no/kultur/i/e8Agdg/khio-studenter-krever-avkoloniseringav-pensum

NESH. (2019, June 8). Guidelines for Research Ethics in the Social Sciences, Humanities, Law and Theology. https://www.forskningsetikk.no/en/guidelines/social-scienceshumanities-law-and-theology/guidelines-for-research-ethics-in-the-socialsciences-humanities-law-and-theology/

Norsk kulturskoleråd. (2020). Kulturskolen som inkluderende kraft i lokalsamfunnet (KIL) [Schools of music and performing art as an inclusive power in local communities]. https://www.kulturskoleradet.no/vi-tilbyr/program-og-prosjekt/kil

Kulturskolenettverket. (2019). Kulturskolemanifest [The manifest of Norwegian schools of music and performing arts]. Kulturrådet. https://www.kulturskoleradet.no/_ extension/media/6775/orig/2019\%20Kulturskolemanifest\%2029.11.pdf 
Lindgren, M. (2006). Att skapa ordning för det estetiska i skolan: Diskursiva positioneringar i samtal med lärare och skolledare [To create systems for aesthetics in school: Discoursive positioning in conversations with teachers and school leaders]. [Doctoral disertation. University of Gotenburg]. https://gupea. ub.gu.se/handle/2077/16773

Lund, A. B. (2018). En studie av læreres forståelse av mangfoldsbegrepet. Nordisk Tidsskrift for Pedagogikk og Kritikk, 4. https://doi.org/10.23865/ntpk.v4.608

Matarasso, F. (2019). A restless art: How participation won and why it matters. Calouste Gulbenkian Foundation. https://arestlessart.files.wordpress. com/2019/03/2019-a-restless-art.pdf

Matarasso, F. (2013). Creative progression: Reflection on quality in participatory arts. UNESCO Observatory Multi-Disciplinary Journal in the Arts, 3(3), 1-15.

Mcclary, S. (2002). Feminine endings: Music, gender, and sexuality (Reprint edition). University of Minnesota Press.

Rønningen, A. (2015). Det etniske steget En drøfting av kulturelt mangfold i pedagogiske tekster for musikk for norsk ungdomsskole [The ethnic step. A discussion on cultural diversity in pedagogical texts in music at lower secondary school]. [Doctoral dissertation. Norwegian Academy of Music.] https://nmh. brage.unit.no/nmh-xmlui/handle/11250/2367236.

St. Pierre, E. A. (2020). Why post qualitative inquiry? Qualitative Inquiry. https://doi. org/10.1177/1077800420931142

Sætre, J. H., Ophus, T., \& Neby, T. B. (2016). Musikkfaget i norsk grunnskole: Læreres kompetanse og valg av undervisningsinnhold i musikk [The music subject in Norwegian primary school: The teachers' competences, and their choice of content in the subject]. Acta Didactica, 10(3), 18.

Skrefsrud, T.-A., \& Østberg, S. (2015). Diversitet i lærerutdanningene - bidrag til en profesjonsorientert forståelse av fag og kunnskapsområder [Diversity in teachereducations - a contribution to a professionoriented understanding of subjects and knowledge fields]. Norsk Pedagogisk Tidsskrift, 99(3-4), 208-219.

Studentenes og Akademikernes Internasjonale Hjelpefond. (SAIH) (2018). Hva mener vi med avkolonisering av høyere utdanning? [What do we mean by decolonization of higher education?]. https://saih.no/artikkel/2018/9/hva-menervi-med-avkolonisering-av-h\% 3 3\%B8yere-utdanning

Østern, A.-L., \& Hovde, S. S. (2019). Untamed stories told by artfully creative artists in Malawi and Norway. In A.-L. Østern \& K. N. Knudsen (Eds.), Performative approaches in arts education: Artful teaching, learning and research (pp. 168-192). Routledge. 


\title{
Er jeg musikalsk? Barnehagelærerstudenters oppfatning av egen musikalitet
}

\section{Jan Ketil Torgersen \& Morten Sæther}

Dronning Mauds Minne Høgskole for barnehagelærerutdanning

\begin{abstract}
This article presents results from a quantitative study of Early Childhood Education and Care (ECEC) student teacher's relationship to music and musicality. Survey data was collected among first-year students at a university college for ECEC at the start of studies in 2013,2014, 2015 and 2017. The survey consists in its entirety of ten different questions. This article discusses four questions from the survey that deal with the students' perception of their own musicality and what it means to be musical.

1,019 responses have been registered, which gives a response rate of approximately $91 \%$ of the total number of students in the four study years the survey was conducted. Frequency analyzes and cross-table analyzes have been performed.

Results show that perceptions of one's own musicality can be put in context with different understandings of what it means to be musical. Musical activity in close family in childhood is important when it comes to musical interest and perception of one's own musicality.

The article discusses the significance of the results in relation to music teaching in higher education.
\end{abstract}

Keywords: musicality, music self-concept, perception of musicality, music teaching, early childhood teacher education

Hvilken oppfatning barnehagelærerstudenter har om egen musikalitet, kan ha betydning for musikkundervisningen i barnehagelærerutdanningen og videre for musikkaktiviteten i barnehagen. Studentenes egen

Sitering av dette kapitlet: Torgersen, J. K. \& Sæther, M. (2021). Er jeg musikalsk? Barnehagelærerstudenters oppfatning av egen musikalitet. I E. Angelo, J. Knigge, M. Sæther \& W. Waagen (Red.), Higher Education as Context for Music Pedagogy Research (s. 297-321). Cappelen Damm Akademisk. https://doi.org/10.23865/ noasp.119.ch12

Lisens: CC BY-NC-ND 4.0. 
oppfatning av fenomenet musikalitet kan forstås som en didaktisk forutsetning for planlegging og gjennomføring av musikkundervisningen i barnehagelærerutdanningen. Musikk er ett av tre kunstfag i kunnskapsområdet kunst, kultur og kreativitet (KKK) i barnehagelærerutdanningen (Kunnskapsdepartementet, 2018). Musikk benyttes sjelden eksplisitt som fagbetegnelse, verken i rammeplanen for barnehagelærerutdanningen (Kunnskapsdepartementet, 2017) eller i de nasjonale retningslinjene for barnehagelærerutdanningen (Kunnskapsdepartementet, 2018). Kunstneriske eller estetiske aktiviteter som beskrives i rammeplanen for utdanningen, oversettes i vår sammenheng til musikalske aktiviteter og prosesser.

Kort oppsummert kan vi si at musikkundervisningen ved Dronning Mauds Minne Høgskole (DMMH) består av to hovedkomponenter: 1) undervisning $i$ musikk og 2) undervisning om musikk. Komponent 1) handler om at undervisningen skal bidra til å utvikle studentenes musikalske ferdigheter, og komponent 2) handler om at studentene skal erverve seg kunnskaper om barns musikalitet og musikalske uttrykk med særlig vekt på kommunikasjon (Bjørkvold, 2005; Malloch \& Trevarthen, 2009; Stern, 2003; Sæther, 2019). Slik vi ser det ut fra de nasjonale retningslinjene, er både utvikling av studentens musikalske ferdigheter og kunnskap om barns musikalske uttrykk i vid forstand vesentlig i barnehagelærerutdanningen.

Ved DMMH legges det vekt på at studentene skal trene og utvikle sine sang- og akkompagnementsferdigheter, slik at de kan anvende disse i barnehagen. Videre erfarer vi at studentene ikke oppfatter at de har tilstrekkelig kunnskap og ferdigheter, og at de derfor kvier seg for å uttrykke seg musikalsk sammen med medstudenter i undervisningen. Denne uttrykte oppfatningen av manglende tro på musikalske ferdigheter utgjorde en motivasjon for å gjennomføre en undersøkelse blant studentene for å kartlegge deres oppfatning av musikalitet og deres forhold til musikk. Resultatene fra undersøkelsen har blitt presentert for og diskutert med studenter som selv har deltatt i undersøkelsen. Dette har gitt muligheter for en metarefleksjon over både selve undersøkelsen og resultatene fra den.

Resultater fra undersøkelsen drøftes ut fra vårt forskningsspørsmål: Hvilken oppfatning har barnehageloererstudenter om egen musikalitet? 


\section{Bakgrunn for studien}

I 2011 ble det gjennomført en pilotundersøkelse om studentenes oppfatning av egen musikalitet, og av hva som menes med det å være musikalsk. 287 studenter, som utgjorde 90 prosent av studentene i første klasse ved høgskolen, svarte skriftlig på et standardisert spørreskjema helt i starten av semestret. Studentene kunne svare utfyllende med egne ord for å forklare sine avkrysninger.

Omtrent $1 / 3$ av studentene svarte at de ikke var musikalske, $1 / 3$ svarte at de var musikalske, og $1 / 3$ svarte «vet ikke». De som svarte at de ikke var musikalske, forklarte musikalitet som ervervede praktiske ferdigheter i musikk. De som sa at de var musikalske, forklarte musikalitet mye videre (for eksempel som evne til å oppleve, like å danse, lytte til musikk og så videre). Dette opplevde vi som interessant, og vi ville finne ut mer om det gjennom en større undersøkelse. Det var ingen graderte svaralternativer (for eksempel Likert-skala), men respondentene kunne skrive egne tilleggskommentarer, noe svært få gjorde. I den undersøkelsen som presenteres i denne artikkelen, valgte vi å ta med flere svaralternativer for å kunne få tak i mer nyanserte data.

I musikkfaget i barnehagelærerutdanningen ved DMMH er barns musikalitet og barns musikalske utvikling et sentralt tema i pensum og i undervisningen. Pensumlitteraturen som benyttes, representerer i hovedsak et relativistisk, relasjonelt og kommunikativt musikalitetssyn (Angelo, 2019; Bjørkvold, 2005; Brändström, 1997; Malloch \& Trevarthen, 2009; Vist, 2005). Musikalitet forstås da som egenskaper alle mennesker har, og ikke som et fenomen for noen utvalgte, som for eksempel kan bety at man har et medfødt talent eller ervervede ferdigheter. Et relativistisk og relasjonelt musikalitetssyn handler, i tråd med Brändström (2006), om å se barns musikalitet som en del av barns estetisk helhetlige, varierte og skapende væremåte.

En inspirasjon for vår undersøkelse har vært Brändströms bok Vem är musikalisk (1997), som er basert på intervjuer med fire musikklærere i barneskolen og fire musikklærerutdannere ved Musikhögskolan i Piteå i Sverige om deres oppfatning av egen musikalitet. Empiri fra Brändströms materiale viser at fenomenet musikalitet ikke er et sentralt tema i utdanningen. Musikalitet er noe man implisitt har som musikkstudent, forstått 
som ferdigheter på høyt nivå, et mer sofistikert nivå som blir «tatt for gitt» (Brändström, 2006). Musikalitetsbegrepet knyttes gjerne til samtaler om hvor raffinert det musikalske uttrykket er, om formidling og interpretasjon. Som musikklærer kan dette ha betydning for hvordan man opplever elevers musikalske utvikling, og for hvem denne undervisningen skal favne.

Vår erfaring er at studentene oppfatter barns musikalitet i vid forstand, men at de, når det gjelder egen musikalitet, stiller «strengere krav» til hva musikalitet er. Dette representerer en mer absolutt forståelse av musikalitet, som ut fra Brändströms tenkning peker mot en medfødt evne til musikalske ferdigheter som er forbeholdt noen få. Det absolutte musikalitetssynet bygger på en elitistisk tenkning om at mennesket enten er eller ikke er musikalsk (Brändström, 2006). Dette kan videre bety at det lar seg gjøre å måle musikalske ferdigheter. Brändström (2006) mener å se at det absolutte musikalitetssynet blir mer og mer gjeldende jo lenger ut i utdanningsforløpet man kommer, men at det på det høyeste nivået muligens også vil nærme seg et mer relativistisk syn.

\section{Musikalitet - et tema i musikkutdanningene?}

Vår erfaring er at temaet musikalitet ikke er sentralt i musikkfagets innhold i lærerutdanningene. I høyere musikkutdanning vil det gjerne være en «tatt for gitt»-oppfatning at studentene er musikalske. Oppfatning av fenomenet musikalitet og av hva som utgjør musikalske forutsetninger, knyttes til den didaktiske kategorien «elev- og lærerforutsetninger» i den didaktiske relasjonsmodellen (Bjørndal \& Lieberg, 1978; Hanken \& Johansen, 2013).

Kunnskap om musikalitetssyn og egen oppfatning av musikalitet er et tema som vi mener bør være sentralt, både for studentenes egen utvikling og for planlegging og gjennomføring av pedagogisk virksomhet i barnehagen. Når det gjelder begrepet «musikalsk», blir det gjerne forstått som noe man er eller ikke er (Angelo, 2019). Oppfatninger av hva musikk er, og om man selv er musikalsk «nok», kan være helt avgjørende for hvilken musikkpedagogiske virksomhet som skjer eller ikke skjer i barnehagen. Det handler blant annet om musikksyn, syn på elever (barn), syn på 
lærer- eller barnehagelærerrollen (Hanken \& Johansen, 2013). For den kommende barnehagelæreren vil et musikkpedagogisk grunnsyn ligge innenfor det vi i vår utdanning betegner som pedagogisk grunnsyn.

I de første møtene med nye studenter i barnehagelærerutdanningen ved DMMH gir mange studenter uttrykk for at de «gruer» seg for musikkundervisningen. Musikk i barnehagelærerutdanningen er obligatorisk, et fag alle må ha bestått for å oppnå godkjenning som barnehagelærer. Ved vår høgskole er musikkundervisningen lagt til første studieår, og det er således et fag studentene møter allerede ved oppstarten av studiet. Mange studenter forteller til sin lærer at de ikke kan synge, eller at de ikke våger å synge alene. Stemmen oppleves som veldig personlig og «avslørende» i noen sammenhenger. Schei (2011) skriver om «stemmeskam» for utøvende sangere, men hennes diskusjoner er også relevant i vår sammenheng. Hun anvender også begrepet «identifisering», der hun beskriver en persons identitet som noe som hele tiden er i utvikling. Sang og stemmebruk har vesentlig betydning for en persons identitetsforståelse, hevder hun (Schei, 2011).

Erfaringen vår er at studentene etter hvert tør opp og ikke lenger er så redde for å spille eller synge. Utfordringen ligger i å kunne tilpasse undervisningen slik at alle får utbytte av den. Dette vil være av betydning med tanke på å våge å uttrykke seg musikalsk og på å gjennomføre musikkaktiviteter i både formelle (planlagte) og uformelle (spontane) situasjoner i barnehagen. Gjennom å hjelpe studentene til å gjenoppdage og aktivere sitt musikalske repertoar fra barndommen kan vi som musikklærere bidra til at studentene får økt mestringsopplevelse og trygghet i slike situasjoner.

\section{Teoretiske perspektiver og tidligere forskning på musikalitet}

Fenomenet musikalitet hører hjemme i musikkpedagogikk som vitenskapsfag. Innenfor musikkdidaktisk tenkning handler det ifølge Nielsen (1997) om både interne og eksterne aktører. Interne aktører er blant annet forholdet mellom den som skal lære, eleven (studenten), og den som underviser (læreren). Videre handler det om innholdet i musikkfaget (hva som skal læres) og rammefaktorer. Rammefaktorer er for 
eksempel lover og bestemmelser, fagplaner og rammeplaner, institusjon (oppdrag eller mandat) og eksterne aktører (Nielsen, 1997). Eksempler på eksterne aktører er personer som indirekte kan ha betydning for musikkundervisningen. Nilsen trekker fram ledere, forskere, politikere, lærebokforfattere og læreplanutviklere.

Brändström (1997) framstiller en skisse for å belyse kjennetegn ved absolutt syn på musikalitet versus relativistisk syn på musikalitet. Et absolutt musikalitetssyn inkluderer at musikalitet er et medfødt fenomen, at det gjelder noen utvalgte, at det handler om musikalske ferdigheter, og at musikaliteten blant annet er målbar, i motsetning til et relativistisk musikalitetssyn der musikalitet er ervervet, gjelder alle, bygger på opplevelse av musikken og ikke er målbar. Innenfor det sistnevnte synet vil det stilles krav til kunnskap og erfaring med formidling, interpretasjon, lytting og musikkopplevelse. Et relativistisk og relasjonelt musikalitetssyn handler, i tråd med Brändström (2006), om å se barns musikalitet som del av barns estetisk helhetlige og skapende væremåte. Dikotomien et absolutt eller et relativistisk musikalitetssyn, slik Brändström (2006) framstiller det, oppleves som relevant ut fra funn i vår undersøkelse om barnehagelærerstudenters oppfatning av musikalitet. Vår forståelse av et absolutt musikalitetssyn vil i denne artikkelen være rettet mot musikalske ferdigheter.

Mye av musikalitetsforskningen har handlet om å kunne måle musikalske evner og ferdigheter. Allerede i 1883 ble ifølge Hallam (2006) den første musikalitetstesten utviklet av Carl Stumpf. Dette var en test som kunne bidra til å finne de musikalsk lovende elevene. Noe senere, og ut fra et strukturalistisk perspektiv, definerer Seashore (1938) musikalitet som et hierarki av kapasiteter. Han beskriver musikalitet som et medfødt fenomen, som kan bety at mennesker har mer eller mindre talent for musikk. Seashore (1938) utarbeidet tester ut fra fem kriterier (kapasiteter) som bygger på hverandre. Hensikten med denne musikalitetstesten kunne være å kartlegge den enkeltes musikalitet, slik at opplæringen kunne ta utgangspunkt i hvilke skårer den enkelte hadde oppnådd i musikalitetshierarkiet (Jørgensen, 1982; Seashore, 1938).

I et gestaltpsykologisk perspektiv, representert ved Mursell (i Jørgensen, 1982; Angelo, 2019) ses musikalitet som en del av et menneskes helhetlige 
personlighet. Han tvilte på at musikaliteten kunne måles med tester, selv om at han også, som Seashore, mente at det har noe med arv å gjøre, men at det er helheten i menneskets oppvekst som har størst betydning. Et vesentlig trekk i Mursells musikalitetsforståelse er at helheten er mer enn summen av delene (Angelo, 2019; Jørgensen, 1982).

Et antropologisk perspektivsyn, representert ved Blacking (1976), handler om å se musikk og musikalitet i sammenheng med den kulturen og det samfunnet det springer ut fra. Musikk handler om kommunikasjon mellom mennesker. Musikk og musikalitet oppfattes på forskjellige måter. I andre kulturer enn den vestlige kan for eksempel evnen til å gjøre og dele musikk inkluderes i fenomenet musikalitet (Elliot, 1995; Small, 1998).

I et eksistensfilosofisk perspektiv ser man på musikalske uttrykk som en del av det å være menneske. Her handler musikalitet om relasjonelle forhold mellom kunst og mennesker, og om hvordan undring og livsspørsmål kan uttrykkes til kunsten. I musikalske sammenhenger kan det dreie seg om evne til å inntone seg i andres uttrykk, eller om å kunne lytte til hverandre. En eksistensorientert tenkning om musikalitet påpeker musikkarbeidet som noe langt ut over det å utvikle rytmisk, tonal eller harmonisk sans, noe som inkluderer evne til å ta aktiv del i, og ansvar for, eget liv (Angelo, 2019, s. 57-58). Pio (2006) knytter tenkningen om musikalitetsbegrepet til en slags klokskap som handler om å kunne håndtere det «komplekse livet» på en god måte.

I en evolusjonsforståelse av musikalitet diskuteres ulike oppfatninger om musikalitet som et biologisk predisponert (medfødt) fenomen som har betydning for språk, og som er en nødvendighet for sosial tilhørighet. I artikkelen «Musicality: Instinct or acquired skill?» (Marcus, 2012) diskuteres musikk som noe grunnleggende for menneskets utvikling.

I et kommunikativt perspektiv forklares musikalitet som en vesentlig del i menneskers kommunikasjon. Særlig oppmerksomhet i forskningen på dette området har vært knyttet til barns kommunikasjonsutvikling (Bjørkvold, 2005; Malloch \& Trevarthen, 2009; Stern, 2003). Musikalitet kan betraktes som et iboende og grunnleggende fenomen som alle mennesker er i besittelse av (Malloch \& Trevarthen, 2009). Musikalitet handler blant annet om at musikalske virkemidler inngår som en 
vesentlig del av kommunikasjonen barn-voksen og barn-barn. Barn oppfattes som musikalske i videste forstand, noe som utgjør grunnlaget for all menneskelig kommunikasjon. Malloch \& Trevarthen beskriver dette som «communicative musicality» (Malloch \& Trevarthen, 2009). Dissanayake (2012) mener blant annet at de tidligste narrativene er musikalske. I noen sammenhenger kan det handle om evne til å inntone seg $\mathrm{i}$ andres uttrykk eller å kunne lytte til den andre. Hun beskriver den tidlige mor-barn-interaksjonen som musikalsk, da hun ser at de samme strukturelle musikalske prinsippene er til stede i rent musikalske uttrykk og i «babyprat». Dette gjelder blant annet de melodiske, rytmiske og dynamiske prinsippene (Dissanayake, 2012).

Malloch og Trevathen (2009) og Stern (2003) beskriver barns forstadier til talespråk som protosamtaler eller protodialog. Det vises her til musikalske uttrykk og virkemidler som sammen med blikk, gester og bevegelser utgjør selve kommunikasjonen.

En kvantitativ studie gjennomført blant lærerstudenter rettet mot barneskolen i Finland, viser blant annet at det er sammenheng mellom musikalsk stimulering og erfaringer fra musikalsk hjemmemiljø i barndommen og betydning for lærerstudentenes musikalske selvoppfatning. Studien viser videre at dette har betydning for progresjon i ens egen musikalske utvikling som voksen (Ruismäki \& Tereska, 2006). I Ruismäki og Tereskas studie viser de til evalueringer med tanke på musikalske situasjoner der sang, lek og skapende musikkaktivitet inngår som særlig betydningfulle for musikalsk selvoppfatning. Dette har videre betydning for den akademiske selvoppfatningen, som blir sentral for lærerstudenter under utdanning og dermed av betydning for generell selvoppfatning. Barnehagelærerstudentenes musikalske erfaringer fra egen barndom kan ut fra denne forståelsen ha betydning for deres oppfatning av egen musikalitet og for utviklingen av deres musikalske ferdigheter i utdanningen.

Goldsmiths Musical Sophistication index (Gold-MSI) er et verktøy for individuell testing av musikalitet som handler om målinger av musikalske holdninger, atferd og ferdigheter. Verktøyet ble utviklet over tid og med flere revisjoner (Müllensiefen et al., 2013). Det består av blant annet et selvrapporteringsskjema (spørreskjema). Hensikten med dette selvrapporteringsskjemaet er a) å undersøke graden av musikalsk 
engasjement, å finne ut noe om variasjon og allsidighet i musikalsk atferd hos en person, og b) å registrere et selvvurdert nivå innen ulike musikalske ferdigheter. De ulike musikalitetsdimensjoner Gold-MSI måler, er:

1) active musical engagement (hvor mye tid tilbrakt på musikk)

2) self-reported perceptual abilities (nivå på musikalske lytteferdigheter)

3) musical training (hvor mye musikkundervisning man har fått)

4) self-reported singing abilities (nivå på egen syngeferdighet)

5) sophisticated emotional engagement with music (evne til å snakke om følelser som musikk uttrykker)

Gold-MSI viser at det er interesse for å få innsikt i ikke-musikeres forståelse for egen musikalitet. Gold-MSI-verktøyet er rettet mot den allmenne befolkningen $i$ en vestlig verden og ikke mot spesielle grupper $i$ samfunnet. Endelig versjon av Gold-MSI ble publisert etter at vi startet vår datainnsamling, og den har derfor ikke hatt direkte påvirkning på studien. Vår undersøkelse er rettet mot barnehagelærerstudenter, men det kan hende disse studentene representerer en heterogen gruppe, ganske lik den vi finner i allmennheten.

Howe et al. (1998) diskuterer forskningsfunn og argumenterer gjennom en forskningsgjennomgang for og imot denne påstanden: «Innate talents: Reality or myth?» I artikkelen stiller de spørsmålet om det er mulig å kunne identifisere et biologisk betinget talent allerede hos små barn. Forskerne oppsummerer i fem kriterier hva som kan ligge til grunn for beskrivelsen av hva et talent er:

1) Et talent har sin opprinnelse i genetisk overførte strukturer.

2) Det er tidlig indikatorer på talent.

3) Talent gir grunnlag for å estimere sannsynligheten for høyt nivå.

4) Kun få mennesker har dette talentet.

5) Virkningen av talentet er relativt spesifikt.

Hallam (2006) peker på tidligere forskning der det vises til paralleller mellom testing av intelligens og musikalske evner (musikalitet). Metoder innen forskningen gjør det så langt ikke mulig å kunne konstatere 
at observerte forskjeller i musikalsk evne hos barn kun er resultat av genetisk arv, læring eller interaksjon mellom de to (Hallam, 2006). Det kan bety at musikalitet ikke er noe konstant, men noe som kan utvikles i samspill med omgivelsene.

De teoretiske perspektivene som her er presentert, viser noe av bredden i oppfatninger av hvordan fenomenet musikalitet kan forstås ut fra ulike vitensområder. Teoretiske perspektiver som vi ser som særlig relevante for vår studie, er dikotomien et absolutt eller et relativistisk musikalitetssyn, slik Brändström (2006) fremstiller det. Videre er musikalitet forstått som kommunikativ musikalitet sentralt, fordi det musikalitetssynet som studentene vil bli presentert for, knyttes til nettopp musikalske kvaliteter i barns helhetlige kommunikasjon og måter å uttrykke seg på (Dissanyake, 2012; Malloch \& Trevharten, 2009; Stern 2003).

\section{Metode}

Grunnlaget for datamaterialet er en kvantitativ spørreundersøkelse som ble gjennomført blant studentene i alle førsteklassene i barnehagelærerutdanningen for studieårene 2012, 2013, $2014 \mathrm{og}$ 2017. Kjønnsfordelingen blant svarene er 79 prosent kvinner og 21 prosent menn, noe som også gjenspeiler kjønnsfordelingen i utdanningen ved DMMH. Undersøkelsen består av ti spørsmål som omhandler blant annet musikksmak, oppfatning av egen musikalitet, hva det betyr å være musikalsk, interesse for musikk, egne ferdigheter innen musikk og ulike definisjoner av hva musikk er. Gjennom sju ulike analyser blir fire av spørsmålene fra musikkundersøkelsen analysert og diskutert. Disse spørsmålene er:

1) Er du musikalsk?

2) Hva betyr det å være musikalsk?

3) Er musikk viktig for deg?

4) Hvem har påvirket deg mest når det gjelder musikkinteresse?

Når det gjelder spørsmålet i undersøkelsen som omhandler definisjonen på musikalitet («hva betyr det å være musikalsk?»), ser vi sammenhenger mellom våre svaralternativer og The Music Self-Perception Inventory (MUSPI) 
(Morin et al., 2017), der de gjennom ulike spørsmål delte respondentenes oppfatning av egen musikalitet inn i seks alternativer: «singing, instrument playing, reading, composing, listening og dancing.» Spørsmål 4 («hvem har påvirket deg mest når det gjelder musikkinteresse?) synes kanskje ikke relevant for forskningsspørsmålet. Men sett i sammenheng med Ruismäki og Tereskas (2006) forskning, som viser til sammenheng mellom musikalsk stimulering og erfaringer fra musikalsk hjemmemiljø i barndommen og betydning for lærerstudentenes musikalske selvoppfatning, vil spørsmål 4 være relevant i vår diskusjon av forskningsspørsmålet.

Spørsmålene i vår undersøkelse har forhåndsdefinerte svaralternativer der studentene har krysset av for det alternativet som passer best («single choice»).

Hvordan vi som forskere i denne studien oppfatter fenomenet musikalitet og egen musikalitet, representerer en forforståelse som har betydning for hvordan spørsmålene ble utformet. Våre preferanser preger også våre analyser, tolkninger og drøfting av funn. Hvordan vi tolker funnene er også knyttet til en kollektiv forståelse av hva som oppfattes som en relevant musikalitetsoppfatning i vår utdanning. Musikkundervisningen ved DMMH er profesjonsrettet, noe som betyr at undervisningen handler om inkluderende musikkaktivitet med barnehagebarn. Vår forforståelse representerer barns iboende musikalitet som viktig i barns opplevelsesverden, kommunikasjonsevne og helhetlige utvikling.

Det har vært viktig at informantene i minst mulig grad skulle være påvirket av vår (forskernes) forståelse av de ulike temaene som undersøkelsen inneholder. Derfor ble undersøkelsen gjennomført helt i starten av første undervisningstime i musikkfaget. Det er likevel klart at besvarelsene til en viss grad er farget av at informantene vet at det de svarer, kommer til å bli tolket av forskere. På den måten vil de, bevisst eller ubevisst og i større eller mindre grad, prøve å tenke seg fram til hva som kan være «rett svar», med tanke på hva forskerne ville ha svart. Besvarelsene ble gjennomført anonymt, og spørsmålene ble utformet slik at svarene ikke skulle kunne knyttes opp mot noe som kunne føre til brudd på anonymiteten. Forskningsetisk kan man stille spørsmål ved at vi er både lærere og forskere for studentene som har deltatt i undersøkelsen, men i og med at datainnsamlingen foregikk i forkant av første undervisningsøkt, har vi klart å holde rollene atskilt. 


\section{Resultater}

I det følgende presenteres resultater fra de ulike analysene. Det er til sammen registrert 1019 besvarelser, noe som gir en svarprosent på 91 prosent av det totale antallet studenter i de fire studieårene undersøkelsen ble gjennomført. Datamaterialet er analysert i statistikkprogrammet SPSS (Statistical Package for the Social Sciences) (IBM, 2020). På grunn av spørsmålenes utforming og begrensede muligheter for graderte svar og for å kunne velge flere svaralternativer, er det i hovedsak frekvensanalyse og krysstabellanalyse som har dannet grunnlaget for de resultatene vi har fătt. Synliggjøring av de ulike resultatene kommer fram gjennom tabeller og grafiske diagrammer. Frekvensanalyser er gjort der det er interessant å finne ulike størrelsesordener innen svargruppen som en helhet. De fleste resultatene har kommet gjennom krysstabellanalyse, der ulike svar i forskjellige spørsmål blir sett i sammenheng med hverandre.

\section{1) Er du musikalsk?}

Tabell 1 Frekvensanalyse: «Er du musikalsk?»

\begin{tabular}{|l|c|c|}
\hline & Antall & Prosent \\
\hline Nei, jeg er ikke musikalsk & 221 & 21,7 \\
\hline Litt musikalsk & 434 & 42,7 \\
\hline Ganske musikalsk & 228 & 22,4 \\
\hline Ja, i stor grad & 100 & 9,8 \\
\hline Jeg vet ikke & 34 & 3,3 \\
\hline Total & 1017 & 100,0 \\
\hline
\end{tabular}

I spørsmålet om hvorvidt studentene anså seg selv som musikalske, fikk de graderte alternativer der de krysset av for det alternativet som passet best med deres oppfatning av egen musikalitet. 21,7 prosent av studentene svarer at de anser seg for ikke å være «musikalsk». Det svaralternativet som har høyest oppslutning - 42,7 prosent - blant studentene, er at de anser seg som «litt musikalsk». 22,4 prosent av studentene sier at de er «ganske musikalsk», mens 9,8 prosent svarer at de «i stor grad» er musikalske. Når man sammenfatter kategoriene 1-2 («ikke musikalsk» / «litt musikalsk») og kategoriene 3-4 
(«ganske musikalsk» / «i stor grad»), fører det til en fordeling på 64,4 prosent versus 32,2 prosent. Utvalget som helhet vurderer sin musikalitet med gjennomsnittlig 2,21 $(S D=0,91$; «ikke musikalsk»=1, «i stor grad»=4).

\section{2) Hva betyr det å være musikalsk?}

Tabell 2 Frekvensanalyse: «Hva betyr det å være musikalsk?»

\begin{tabular}{|l|c|c|}
\hline & Antall & Prosent \\
\hline Å kunne spille et instrument & 144 & 14,8 \\
\hline$\AA ̊$ være glad i å lytte til musikk & 281 & 28,8 \\
\hline$\AA$ ha et godt gehør & 272 & 27,9 \\
\hline$\AA$ kunne synge eller spille etter noter & 261 & 26,7 \\
\hline A kunne danse til musikk & 18 & 1,8 \\
\hline Total & 976 & 100,0 \\
\hline
\end{tabular}

For å finne ut hva studentene legger i begrepet «musikalsk», fikk de ulike alternativer å velge mellom (tabell 2). Oppsummert ser vi at studentene legger vekt på et ferdighetssyn når det gjelder oppfatning av egen musikalitet. Det dreier seg om tilegnelse av musikalske ferdigheter, som det å kunne spille et instrument, å kunne synge eller spille etter noter og å kunne danse til musikk. I vår behandling av datamaterialet ser vi at det er en betydelig overvekt av ferdighetsrelaterte svaralternativer. I og med at fire av fem alternativer er knyttet opp mot musikalske ferdigheter, er disse med på å påvirke studentenes svar. Likevel mente 28,8 prosent av studentene at musikalitet handler om å være glad i å lytte til musikk. Dette er i tråd med et mer relativistisk musikalitetssyn, der spesielle ferdigheter ikke er i søkelyset. Selv om dette er det eneste alternativet som klart viser et relativistisk musikalitetssyn, viser det seg også at det er det alternativet som har flest svar. 27,9 prosent av studentene hadde krysset av for det siste alternativet, «å ha et godt gehør». Det kan være vanskelig for studentene å ha en enhetlig oppfatning hva de legger i begrepet «godt gehør», men vår erfaring er at studentene kobler det opp mot det å synge rent. Hvorvidt denne evnen er medfødt eller er en opparbeidet ferdighet, er en problemstilling vi ikke drøfter i denne artikkelen, men det kan argumenteres for denne evnen i begge overnevnte musikalitetssyn. 


\section{3) Krysstabellanalyse: «Er du musikalsk?» versus «hva betyr det å være musikalsk?»}

Tabell 3 Krysstabellanalyse: «Er du musikalsk?» versus «hva betyr det å være musikalsk?»

\begin{tabular}{|c|c|c|c|c|c|c|c|c|}
\hline & & & \multicolumn{5}{|c|}{ Hva betyr det å være musikalsk? } & \multirow[b]{2}{*}{ Total } \\
\hline & & & $\begin{array}{c}\text { Å kunne } \\
\text { spille et } \\
\text { instrument }\end{array}$ & $\begin{array}{l}\text { A være } \\
\text { glad i å } \\
\text { lytte til } \\
\text { musikk }\end{array}$ & $\begin{array}{c}\text { A ha et } \\
\text { godt } \\
\text { gehør }\end{array}$ & $\begin{array}{l}\text { Å kunne } \\
\text { synge } \\
\text { eller } \\
\text { spille } \\
\text { etter } \\
\text { noter }\end{array}$ & $\begin{array}{c}\AA \\
\text { kunne } \\
\text { danse } \\
\text { til } \\
\text { musikk }\end{array}$ & \\
\hline \multirow{10}{*}{$\begin{array}{l}\text { Er du } \\
\text { musikalsk? }\end{array}$} & \multirow{2}{*}{$\begin{array}{l}\text { Nei, jeg } \\
\text { er ikke } \\
\text { musikalsk }\end{array}$} & Antall & 58 & 22 & 48 & 84 & 1 & 213 \\
\hline & & $\%$ & $27,2 \%$ & $10,3 \%$ & $22,5 \%$ & $39,4 \%$ & $0,5 \%$ & $100,0 \%$ \\
\hline & \multirow{2}{*}{$\begin{array}{l}\text { Litt } \\
\text { musikalsk }\end{array}$} & Antall & 51 & 137 & 115 & 107 & 8 & 418 \\
\hline & & $\%$ & $12,2 \%$ & $32,8 \%$ & $27,5 \%$ & $25,6 \%$ & $1,9 \%$ & $100,0 \%$ \\
\hline & \multirow{2}{*}{$\begin{array}{l}\text { Ganske } \\
\text { musikalsk }\end{array}$} & Antall & 20 & 77 & 67 & 49 & 6 & 219 \\
\hline & & $\%$ & $9,1 \%$ & $35,2 \%$ & $30,6 \%$ & $22,4 \%$ & $2,7 \%$ & $100,0 \%$ \\
\hline & \multirow{2}{*}{$\begin{array}{l}\text { Ja, i stor } \\
\text { grad }\end{array}$} & Antall & 10 & 37 & 32 & 8 & 3 & 90 \\
\hline & & $\%$ & $11,1 \%$ & $41,1 \%$ & $35,6 \%$ & $8,9 \%$ & $3,3 \%$ & $100,0 \%$ \\
\hline & \multirow{2}{*}{$\begin{array}{l}\text { Jeg vet } \\
\text { ikke }\end{array}$} & Antall & 5 & 7 & 10 & 12 & 0 & 34 \\
\hline & & $\%$ & $14,7 \%$ & $20,6 \%$ & $29,4 \%$ & $35,3 \%$ & $0,0 \%$ & $100,0 \%$ \\
\hline \multirow{2}{*}{\multicolumn{2}{|c|}{ Total \% }} & Antall & 144 & 280 & 272 & 260 & 18 & 974 \\
\hline & & $\%$ & $14,8 \%$ & $28,7 \%$ & $27,9 \%$ & $26,7 \%$ & $1,8 \%$ & $100,0 \%$ \\
\hline
\end{tabular}

Ved å utføre en krysstabellanalyse mellom spørsmålene «er du musikalsk?» og «hva betyr det å være musikalsk?» kan vi finne ut av om det er tendenser til ulike musikalitetsoppfatninger ut fra hvor studentene plasserer seg selv innenfor syn på musikalitet. Av de fem alternativene representert $\mathrm{i}$ «hva betyr det å være musikalsk?», har vi valgt ikke å kommentere «å kunne danse til musikk», da dette alternativet er representert ved bare 1,8 prosent av svarene.

Blant studentene som betegner seg selv som «ikke musikalsk», er ferdighetsrelatert musikkoppfatning dominerende: «å kunne spille et instrument» (27,2 prosent), «å kunne synge eller spille etter noter» (39,4 prosent). 22,5 prosent valgte «å ha et godt gehør», mens 12,2 prosent mener at det å være musikalsk er «å være glad i å lytte til musikk». De som anser seg som «litt musikalsk», har en litt annen oppfatning: 12,2 prosent valgte «å kunne spille et instrument», 25,6 prosent valgte 
«å kunne synge eller spille etter noter», og 27,5 prosent mente at «å ha et godt gehør» definerte det å være musikalsk. Den største forskjellen mellom disse to gruppene («ikke musikalsk» og «litt musikalsk») er «å være glad i å lytte til musikk». 32,8 prosent blant dem som mente de var «litt musikalsk», valgte dette alternativet, mot 10,3 prosent blant dem som krysset av for «ikke musikalsk». Blant dem som oppfatter seg selv som «ganske musikalsk» og musikalske «i stor grad», er det en overvekt av «å være glad i å lytte til musikk» - henholdsvis 35,2 prosent og 41,1 prosent. «Å kunne spille et instrument» har en forholdsvis liten representasjon blant disse studentene; 9,1 prosent av dem som anser seg som «ganske musikalsk», og 11,1 prosent av dem som sier at de «i stor grad» er musikalske. 8,9 prosent av de sistnevnte mener at musikalitet handler om «å kunne synge eller spille etter noter», mens 22,4 prosent av dem som anser seg som «ganske musikalsk», har den samme oppfatningen. «A kunne danse til musikk» er det bare 1,8 prosent av studentene som anser som å være musikalsk. «Å ha et godt gehør» kan, som tidligere nevnt, forstås ut fra både et relativistisk og et ferdighetsrelatert musikalitetssyn. Det er interessant å se at dette alternativet har nest høyest skår på alle gradene av selvoppfattet musikalitet, bortsett fra hos dem som anser seg som «ikke musikalsk», der alternativet ligger som nummer tre. Hvorvidt studentene anser «å ha et godt gehør» som en medfødt egenskap, noe man erverver seg, eller en kombinasjon av disse, vil være et interessant tema å ta opp i en senere undersøkelse.

\section{4) Frekvensanalyse: «Er musikk viktig for deg?»}

Tabell 4 Frekvensanalyse: «Er musikk viktig for deg?»

\begin{tabular}{|l|l|r|r|}
\hline \multicolumn{2}{|l|}{} & Antall & Prosent \\
\hline \multirow{3}{*}{ Er musikk viktig for deg? } & Nei, ikke i det hele tatt & 10 & 1,0 \\
\cline { 2 - 4 } & Litt & 125 & 12,4 \\
\cline { 2 - 4 } & Ja, ganske viktig & 273 & 27,1 \\
\cline { 2 - 4 } & Musikk er veldig viktig & 295 & 29,2 \\
\cline { 2 - 4 } & Jeg kan ikke klare meg uten & 306 & 30,3 \\
\cline { 2 - 4 } & Total & 1009 & 100,0 \\
\hline
\end{tabular}


En frekvensanalyse av spørsmålet «er musikk viktig for deg?» viser at 1 prosent av studentene anser musikk som ikke viktig i det hele tatt. 12,4 prosent mener at musikk er litt viktig, 27,1 prosent mener at musikk er ganske viktig, 29,2 prosent mener at musikk er veldig viktig, og hele 30,3 prosent av studentene svarer «kan ikke klare meg uten» musikk. Gjennomsnittlig vurderer studiens utvalg musikkens viktighet med 3,76 $(S D=1,05$; «ikke i det hele tatt» = 1, «jeg kan ikke klare meg uten» = 5), det vil altså si at et stort flertall av studentene anser musikk som en viktig del av livet.

\section{5) Krysstabellanalyse: «Er du musikalsk?» versus «er musikk viktig for deg?»}

Tabell 5 Krysstabellanalyse: «Er du musikalsk?» versus «er musikk viktig for deg?»

\begin{tabular}{|c|c|c|c|c|c|c|c|c|}
\hline & \multicolumn{5}{|c|}{ Er musikk viktig for deg? } & \multirow[t]{2}{*}{ Total } \\
\hline & & & $\begin{array}{c}\text { Nei, ikke } \\
\text { i det hele } \\
\text { tatt }\end{array}$ & Litt & $\begin{array}{c}\text { Ja, } \\
\text { ganske } \\
\text { viktig }\end{array}$ & $\begin{array}{c}\text { Musikk } \\
\text { er veldig } \\
\text { viktig }\end{array}$ & $\begin{array}{l}\text { Jeg kan } \\
\text { ikke klare } \\
\text { meg uten }\end{array}$ & \\
\hline \multirow{10}{*}{$\begin{array}{l}\text { Er du } \\
\text { musikalsk? }\end{array}$} & \multirow{2}{*}{$\begin{array}{l}\text { Nei, jeg } \\
\text { er ikke } \\
\text { musikalsk }\end{array}$} & Antall & 7 & 60 & 65 & 47 & 38 & 217 \\
\hline & & $\%$ & $3,2 \%$ & $27,6 \%$ & $30,0 \%$ & $21,7 \%$ & $17,5 \%$ & $100,0 \%$ \\
\hline & \multirow{2}{*}{$\begin{array}{l}\text { Litt } \\
\text { musikalsk }\end{array}$} & Antall & 3 & 55 & 142 & 140 & 91 & 431 \\
\hline & & $\%$ & $0,7 \%$ & $12,8 \%$ & $32,9 \%$ & $32,5 \%$ & $21,1 \%$ & $100,0 \%$ \\
\hline & \multirow{2}{*}{$\begin{array}{l}\text { Ganske } \\
\text { musikalsk }\end{array}$} & Antall & 0 & 5 & 45 & 77 & 99 & 226 \\
\hline & & $\%$ & $0,0 \%$ & $2,2 \%$ & $19,9 \%$ & $34,1 \%$ & $43,8 \%$ & $100,0 \%$ \\
\hline & \multirow{2}{*}{$\begin{array}{l}\text { Ja, i stor } \\
\text { grad }\end{array}$} & Antall & 0 & 0 & 10 & 21 & 68 & 99 \\
\hline & & $\%$ & $0,0 \%$ & $0,0 \%$ & $10,1 \%$ & $21,2 \%$ & $68,7 \%$ & $100,0 \%$ \\
\hline & \multirow{2}{*}{$\begin{array}{l}\text { Jeg vet } \\
\text { ikke }\end{array}$} & Antall & 0 & 5 & 10 & 10 & 9 & 34 \\
\hline & & $\%$ & $0,0 \%$ & $14,7 \%$ & $29,4 \%$ & $29,4 \%$ & $26,5 \%$ & $100,0 \%$ \\
\hline \multirow{2}{*}{\multicolumn{2}{|c|}{ Total }} & Antall & 10 & 125 & 272 & 295 & 305 & 1007 \\
\hline & & $\%$ & $1,0 \%$ & $12,4 \%$ & $27,0 \%$ & $29,3 \%$ & $30,3 \%$ & $100,0 \%$ \\
\hline
\end{tabular}

For å se om det er noen sammenheng mellom hvor viktig musikk er for studentene og deres syn på egen musikalitet, ble det foretatt en krysstabellanalyse mellom disse to spørsmålene i spørreundersøkelsen. Det vil 
være nærliggende å gå ut fra at hvorvidt musikk er en viktig del av livet, vil korrelere positivt med graden av musikalitet. Dette stemmer for så vidt $(r=0,41, p<0,01)$, men det som kanskje er mest interessant, er hvor viktig musikk er for dem som anser seg som «ikke musikalsk». Blant dem som beskriver seg som «ikke musikalsk», finner vi at bare 3,2 prosent sier at musikk ikke er viktig i det hele tatt, mens 21,7 prosent anser musikk som veldig viktig for dem. 17,5 prosent sier «kan ikke klare meg uten» musikk. Selv om musikk er en viktig del av livet deres, inngår ikke dette alternativet som en definisjon av hva musikalitet er for disse studentene. Det kan altså synes som at det ikke er en tydelig sammenheng mellom angitt musikkinteresse og studentenes svar på om de er musikalske eller ikke. Selv de som oppfatter seg som «ikke musikalsk», gir uttrykk for å ha glede av og interesse for musikk.

\section{6) Frekvensanalyse: «Hvem har påvirket deg mest når det gjelder musikkinteresse?»}

Tabell 6 Frekvensanalyse: «Hvem har påvirket deg mest når det gjelder musikkinteresse?»

\begin{tabular}{|l|l|r|r|}
\hline \multicolumn{2}{|c|}{} & Antall & Prosent \\
\hline \multirow{4}{*}{$\begin{array}{l}\text { Hvem } \\
\text { påvirket? }\end{array}$} & Foreldre & 251 & 26,1 \\
\cline { 2 - 4 } & Søsken & 86 & 9,0 \\
\cline { 2 - 4 } & Venner & 308 & 32,1 \\
\cline { 2 - 4 } & Lærere & 44 & 4,6 \\
\cline { 2 - 4 } & Ulike media & 250 & 26,0 \\
\cline { 2 - 4 } & Uaktuelt - ikke spesielt interessert i musikk & 21 & 2,2 \\
\cline { 2 - 4 } & Total & 960 & 100,0 \\
\hline
\end{tabular}

Alternativene i dette spørsmålet er valgt ut fra forhåndsundersøkelser blant kollegaer og studenter om aktuelle påvirkningskilder fra barndommen når det gjelder interesse for musikk. 26,1 prosent av studentene svarer at foreldre har hatt størst påvirkningskraft. 9 prosent har blitt mest påvirket av søsken. 32,1 prosent krysset av for «venner», mens 26,2 prosent oppga ulike media. 


\section{7) Krysstabellanalyse: «Er du musikalsk?» versus «hvem har påvirket deg mest når det gjelder musikkinteresse?»}

Tabell 7 Krysstabellanalyse: «Er du musikalsk?» versus «hvem har påvirket deg mest når det gjelder musikkinteresse?»

\begin{tabular}{|c|c|c|c|c|c|c|c|c|c|}
\hline & & & \multicolumn{6}{|c|}{$\begin{array}{l}\text { Hvem har påvirket deg mest når det gjelder } \\
\text { musikkinteresse? }\end{array}$} & \multirow[t]{2}{*}{ Total } \\
\hline & & & Foreldre & Søsken & Venner & Lærere & $\begin{array}{l}\text { Ulike } \\
\text { media }\end{array}$ & \begin{tabular}{|c|} 
Uaktuelt - \\
ikke \\
spesielt \\
interessert \\
i musikk \\
\end{tabular} & \\
\hline \multirow{10}{*}{$\begin{array}{l}\text { Er du } \\
\text { musikalsk? }\end{array}$} & \multirow{2}{*}{$\begin{array}{l}\text { Nei, jeg } \\
\text { er ikke } \\
\text { musikalsk }\end{array}$} & Antall & 20 & 17 & 84 & 10 & 64 & 16 & 211 \\
\hline & & $\%$ & $9,5 \%$ & $8,1 \%$ & $39,8 \%$ & $4,7 \%$ & $30,3 \%$ & $7,6 \%$ & $100,0 \%$ \\
\hline & \multirow{2}{*}{ Litt } & Antall & 89 & 40 & 138 & 15 & 124 & 4 & 410 \\
\hline & & $\%$ & $21,7 \%$ & $9,8 \%$ & $33,7 \%$ & $3,7 \%$ & $30,2 \%$ & $1,0 \%$ & $100,0 \%$ \\
\hline & \multirow{2}{*}{$\begin{array}{l}\text { Ganske } \\
\text { musikalsk }\end{array}$} & Antall & 89 & 19 & 57 & 14 & 38 & 0 & 217 \\
\hline & & $\%$ & $41,0 \%$ & $8,8 \%$ & $26,3 \%$ & $6,5 \%$ & $17,5 \%$ & $0,0 \%$ & $100,0 \%$ \\
\hline & \multirow{2}{*}{$\begin{array}{l}\text { Ja, i stor } \\
\text { grad }\end{array}$} & Antall & 48 & 6 & 14 & 5 & 17 & 0 & 90 \\
\hline & & $\%$ & $53,3 \%$ & $6,7 \%$ & $15,6 \%$ & $5,6 \%$ & $18,9 \%$ & $0,0 \%$ & $100,0 \%$ \\
\hline & \multirow{2}{*}{$\begin{array}{l}\text { Jeg vet } \\
\text { ikke }\end{array}$} & Antall & 5 & 2 & 15 & 0 & 7 & 1 & 30 \\
\hline & & $\%$ & $16,7 \%$ & $6,7 \%$ & $\begin{array}{l}50,0 \\
\%\end{array}$ & $0,0 \%$ & $23,3 \%$ & $3,3 \%$ & $100,0 \%$ \\
\hline \multirow{2}{*}{\multicolumn{2}{|c|}{ Total }} & Antall & 251 & 84 & 308 & 44 & 250 & 21 & 958 \\
\hline & & $\%$ & $26,2 \%$ & $8,8 \%$ & $32,2 \%$ & $4,6 \%$ & $26,1 \%$ & $2,2 \%$ & $100,0 \%$ \\
\hline
\end{tabular}

Krysstabellen for «er du musikalsk» versus «hvem har påvirket deg mest når det gjelder musikkinteresse?» viser hvem studentene mener har bidratt mest til deres interesse for musikk: Blant dem som definerer seg som «ikke musikalsk», er det venner (39,8 prosent) og ulike media (30,3 prosent) som er de største påvirkningsfaktorene for musikkinteresse. Venner (33,7 prosent) og ulike media (30,2 prosent) er også de største påvirkningsfaktorene for dem som anser seg som «litt musikalsk». Det som er interessant ved den sistnevnte gruppen, er at foreldre (21,7 prosent) begynner å gjøre seg gjeldende. Og ser vi på dem som anser seg som «ganske musikalsk» og musikalske «i stor grad», er foreldre den gruppen som påvirker musikkinteressen mest, med henholdsvis 41 prosent og 
53,3 prosent. Foreldrenes rolle kan dermed synes viktigere for musikkinteressen jo mer man definerer seg som musikalsk. En annen interessant observasjon er at læreres betydning for musikkinteresse jevnt over er lav, uansett i hvilken grad studentene definerer seg som musikalske.

\section{Diskusjon}

Vårt forskningsspørsmål har vært: Hvilken oppfatning har barnehageloererstudenter om egen musikalitet? Vår motivasjon for å gjennomføre denne studien har vært basert på våre erfaringer i møte med studentene ved studiestart, der de har uttrykt skepsis eller frykt for å uttrykke seg musikalsk i undervisningssammenheng. Flere studenter sier at de ikke kan synge eller er musikalske. Hvilken oppfatning barnehagelærerstudenter har om egen musikalitet, kan ha betydning for musikkundervisningen i barnehagelærerutdanningen og videre for musikkaktiviteten i barnehagen. Studentenes egen oppfatning av fenomenet musikalitet kan forstås som en didaktisk forutsetning for planlegging og gjennomføring av musikkundervisningen i barnehagelærerutdanningen ved DMMH. Elevers, eller i denne sammenhengen studenters, forutsetninger er viktig for å kunne tilrettelegge for tilpasset musikkundervisning (Hanken \& Johansen, 2013, s. 44).

Musikkundervisningen ved DMMH har som hensikt å kvalifisere studenter til å gjennomføre musikkaktiviteter i barnehagen. Med dette som utgangspunkt ser vi en hovedutfordring: Hvordan kan vi møte studentene slik at de får både selvtillit og motivasjon til å uttrykke seg musikalsk, slik at de med trygghet vil synge, utøve musikk, både med barn og sammen med andre voksne i barnehagen?

I det følgende kommenteres kort resultater fra frekvensanalysene, og diskusjonen knyttes til krysstabellanalysene ut fra vårt hovedspørsmål, «er du musikalsk?», i sammenheng med hva studentene svarer i korrelasjon til spørsmålene «hva betyr det å være musikalsk?», «er musikk viktig for deg?» og «hvem har påvirket deg mest når det gjelder musikkinteresse?».

Vår erfaring er at studentenes musikalske ferdigheter varierer stort, og, som resultatene viser i denne undersøkelsen, at en større andel av dem oppfatter seg som lite eller ikke musikalske når de forklarer musikalitet ut 
fra ferdigheter som det å kunne spille, synge, lese noter og ha godt gehør. Et utvidet musikalitetssyn kan knyttes til evner som eksperimentering, lek med musikalske grunnelementer, lytting, rim og regler. Dette kan bidra til at flere studenter opplever mestring og får motivasjon for egen musikalsk utvikling.

I studiens hovedspørsmål, «er du musikalsk?», svarer en større andel av studentene at de «ikke» eller «i liten grad» oppfatter seg som musikalske (til sammen 64,4 prosent). At studentene oppfatter seg som ikke eller lite musikalske, har i særlig grad betydning for musikklærerens første møte med studentene. Studentene viser at de har en oppfatning av hva fenomenet er, uten at vi vet hva de legger i det. I neste spørsmål, der studentene kan krysse av for hva det betyr å være musikalsk, ser vi at svaralternativene knyttes mot allerede ervervede musikalske ferdigheter, og slik vi ser det, heller dette synet mot et ferdighetsorientert musikalitetssyn (Brändström, 1997). Vektleggingen av musikalske ferdigheter som forklaring på musikalitet representerer, slik vi ser det, en smalere oppfatning enn vi formidler i vår undervisning ved $\mathrm{DMMH}$, der musikkundervisningen tar utgangspunkt $i$ at alle er musikalske, et syn som inkluderer noe mer enn musikalske ferdigheter, og der alle har utviklingspotensial. Hallam (2006) viser til forskning som studerer paralleller mellom intelligens og musikalske evner, der man kan forstå musikalitet som noe som ikke er konstant, men som noe som kan utvikles i samspill med omgivelsene. Dette er også i tråd med nasjonale retningslinjer for barnehagelærerutdanning (Kunnskapsdepartementet, 2018), studieplan for barnehagelærerutdanning ved DMMH (2013) og pensumlitteratur (Angelo, 2019; Bakke et al., 2017; Sæther, 2019). Vi har selv vært aktive i utviklingen av studieplaner og læremidler, der vår forforståelse av syn på musikalitet kommer til uttrykk. Dette er eksempler på det Nielsen (1997) forklarer som eksterne aktører, og som kan ha betydning for musikkundervisningen.

Musikalitetsforskningen har handlet mye om å teste musikalske ferdigheter (Hallam, 2006). Hallam viser til strukturalisten Seashore (1938), som definerer musikalitet ut fra et hierarki av kapasiteter. Vi ser at mange av testene også i dag handler mye om kartlegging av ferdigheter eller oppfatning av egne musikalske ferdigheter (Fiedler \& Spychiger, 
2017; Müllensiefen et al., 2013). Dette kan ha betydning for hvordan allmennheten oppfatter hva musikalitet handler om. Vi opplever i media stor satsing på musikalske talentkonkurranser som for eksempel Idol, Stjernekamp og The Voice. Dette kan også ha betydning for at mange studenter oppfatter seg som lite eller ikke musikalske.

I spørsmålet om musikk er viktig for dem (tabell 4), svarte 99 prosent av de spurte at musikk i større eller mindre grad er en viktig del av livet. Vi ser av tabell 5 at betydningen av musikk i studentenes liv ikke ses i sammenheng med deres oppfatning av det å være musikalsk. Evne til å lytte til, oppleve og glede seg over musikk er sentralt i barnehagen (Kunnskapsdepartementet, 2017). I musikkundervisningen vil det være relevant å inkludere musikkengasjement som del av fenomenet musikk.

Resultatene fra krysstabellanalyse mellom studentenes oppfatning av egen musikalitet og påvirkning av musikkinteresse (tabell 7) kan ses i sammenheng med finsk forskning (Ruismäki \& Tereska, 2006), som viser en forbindelse mellom tidlig musikalsk stimulering, erfaringer fra musikalsk hjemmemiljø i barndommen og betydning for lærerstudentenes musikalske selvoppfatning. Studien viser videre at dette har betydning for progresjon i egen musikalske utvikling som voksen. Vi mener å se en tendens til dette også i vår undersøkelse. Den viser at foreldres rolle (et musikalsk hjemmemiljø) som påvirkningskraft for musikkinteresse synes å være større jo mer studentene anser seg som musikalske (53,3 prosent blant dem som anser seg som musikalske «i stor grad»). I musikkundervisningen ved DMMH vil oppmerksomhet på aktivering av studentenes musikalske erfaringer og kompetanse fra egen barndom kunne bidra til en mer positiv musikalsk selvoppfatning og progresjon i musikalsk utvikling blant studentene. En slik aktivering kan gjøres gjennom at studentene stimuleres til å huske eller gjenoppdage musikkopplevelser og sanger fra barndommen.

\section{Avslutning}

Musikkundervisningen i barnehagelærerutdanningen ved DMMH har som formål å kunne bidra til å utvikle musikalsk kompetanse hos kommende barnehagelærere. Dette handler om øving for å utvikle studentenes 
musikalske ferdigheter. I tillegg vil musikkundervisningen handle om å se musikk i sammenheng med andre fag og kunnskapsområder. Her kan nevnes spesielt å se musikk som del av barns kommunikasjon og narrative uttrykk (Dissanyake, 2012; Malloch \& Trevarthen, 2009).

Vår motivasjon for å gjennomføre denne musikkundersøkelsen blant studentene har vært å kunne kartlegge studentenes forhold til musikk og musikalitet fordi vi mener at det kunne gi oss kunnskap om studentenes forutsetninger som utgangspunkt for planlegging og gjennomføring av musikkundervisningen ved DMMH.

Hovedresultatene som er presentert i denne artikkelen, viser at det kan synes å eksistere en sammenheng mellom de studentene som sier at de ikke er musikalske og en ferdighetsorientert musikalitetsforståelse. De som i større grad definerer seg som musikalske, svarer mer i tråd med en relativistisk og relasjonell musikalitetsoppfatning (Brändström, 1997). Videre kan vi se at studenter som anser seg som «ganske» musikalske og i «stor grad» musikalske, oppgir at foreldrene har vært av størst betydning for deres musikkinteresse. Ut fra dette kan vi anta at tidlig musikalsk stimulering i hjemmemiljøet har en positiv effekt på studentenes musikalske selvoppfatning og kan ha betydning for progresjon. Dette finner vi igjen i finsk forskning vi har referert til, som viser at et rikt musikalsk hjemmemiljø i barndommen har betydning for musikalsk utvikling også i voksen alder (Ruismäki \& Tereska, 2006).

En hovedutfordring er å legge til rette for at alle studenter skal få utbytte av musikkundervisningen, og hvordan den kan bidra til den enkelte studentens musikalske utvikling. Store deler av musikkundervisningen ved DMMH er knyttet opp mot praktisk musikkarbeid. Studentene blir opplært i akkompagnementsinstrumenter, de utøver samspill, og de synger. I den sammenheng kan det være en utfordring å argumentere for et relativistisk musikalitetssyn, samtidig som det i betydelig grad er søkelys på musikalske ferdigheter i undervisningen. Eller sett fra en annen synsvinkel: Hvordan kan vi argumentere for ferdighetstrening i musikkundervisningen når vi selv formidler et relativistisk musikalitetssyn? Det vil derfor være viktig å kunne gi studentene en forstålse av at alle er musikalske, i betydningen at vi alle har et musikalsk utviklingspotensial. Vi ser at det vil være en god mulighet å kunne å 
starte musikkundervisningen med sanger, regler, lyttestoff med mer som allerede er kjent for studentene. Det kan skape trygghet og en bevissthet om at de allerede har "gyldige» musikalske erfaringer og kanskje motivasjon for øving og progresjon.

\section{Videre forsknings- og analysearbeid}

Det hadde vært interessant å vite om våre studenter skiller seg fra studenter ved andre studier og studiesteder. Her regnes ikke musikkutdanninger som aktuelle i denne sammenhengen, da man kan tenke seg at musikkstudenter oppfatter seg som musikalske basert på musikalske ferdigheter. Er det slik at de som starter på barnehagelærerstudiet, representerer «en allmenn oppfatning» av musikalitet? Å sammenligne funn fra for eksempel ingeniør- og sykepleierutdanninger med funn fra vår undersøkelse kan i så måte være et relevant prosjekt.

Et annet perspektiv som er aktuelt å studere nærmere, er studentenes oppfatning av hvilken kompetanse de har fått gjennom musikkundervisningen ved DMMH, særlig med tanke på deres egen utvikling og ikke minst om de føler seg rustet til musikkpedagogisk virksomhet i barnehagen.

I undersøkelsen hadde studentene anledning til å krysse av for kun ett alternativ på hvert spørsmål. Dette kan anses som en svakhet ved undersøkelsen, da muligheten for å velge flere alternativer falt bort i de tilfellene studentene vurderte to eller flere alternativer som likestilte. Undersøkelsen ble gjennomført analogt (på papir), noe som medførte at enkelte studenter glemte å svare på alle spørsmålene eller krysset av for flere alternativer. Ved en digital gjennomføring av undersøkelsen kunne dette ha vært unngått. Det er imidlertid ganske få feilbesvarelser på de ulike spørsmålene, og disse går ikke ut over validiteten av resultatene. Ut fra våre erfaringer kan det være aktuelt å endre en framtidig undersøkelses design med tanke på svaralternativer som kan bidra til bedre nyansering av resultatene i en utvidet studie. Deler av Goldsmiths Musical Sophistication Index (Gold-MSI) kan være til nytte i denne sammenhengen, da dette måleverktøyet ser ut til å ha relevans for vårt forskningsfokus. 


\section{Referanser}

Angelo, E. (2019). Musikalitet. I M. Sæther \& E. Angelo (Red.), Barnet og musikken (s. 41-61). Universitetsforlaget.

Bakke, K., Jenssen, C. \& Sæbø, A. B. (Red.). (2017). Kunst, kultur og kreativitet. Kunstfaglig arbeid i barnehagen (2. utg.). Fagbokforlaget.

Bjørkvold, J.-R. (2005). Det musiske menneske. Freidig forlag.

Bjørndal, B. \& Lieberg, S. (1978). Nye veier i didaktikken? En innføring i didaktiske emner og begreper. Aschehoug.

Blacking, J. (1976). How musical is man? Faber \& Faber.

Brändström, S. (1997). Vem är musikalisk? Intervjuer med musiklärare och musiklärarutbildare. KMH Förlaget.

Brändström, S. (2006). Musikalitet och lärandet. I I. E. Alerby \& J. Elidottir, J. (Red.), Lärandets konst: betraktelser av estetiska dimensioner i lärandet (s. 143-156). Studentlitteratur.

Dronning Mauds Minne Høgskole. (2013). Studieplan for barnehagelærerutdanning 2018-2021. https://studier.dmmh.no/nb/studieplaner/2018/Barnehagel\%C3\%A6 rerutdanning

Dissanyake, E. (2012). The earliest narratives were musical. Research Studies in Music Education, 34(1), 3-14.

Elliot, D. J. (1995). Music matters: A new philosophy of music education. Oxford University Press.

Fiedler, D. \& Spychiger, M. (2017). Measuring 'musical self-concept' throughout years of adolescence with MUSCI-youth: Validation and adjustment of the musical self-concept inquiry (MUSCI) by investigating samples of students at secondary education schools. Psychomusicology: Music, Mind and Brain, 27(3), 167-179.

Hallam, S. (2006). Musicality. I G. E. McPherson (Red.), The child as musician: A handbook of musical development (s. 93-110). Oxford University Press.

Hanken, I. M. \& Johansen, G. (2013). Musikkundervisningens didaktikk. Cappelen Damm Akademisk.

Howe, M. J. A., Davidson, J. W. \& Sloboda, J. A. (1998). Innate talents: Reality or myth? Behavioral and Brain Sciences, 21(3), 399-407. https://doi.org/10.1017/ So140525X9800123X

IBM. (2020). Statistical package for the social sciences (SPSS) (Versjon 26). https:// www.ibm.com/analytics/spss-statistics-software

Jørgensen, H. (1982). Fire musikalitetsteorier. Aschehoug.

Kunnskapsdepartementet. (2017). Rammeplan for barnehagens innhold og arbeidsoppgaver. Udir. https://www.udir.no/laring-og-trivsel/rammeplan/

Kunnskapsdepartementet. (2018). Nasjonale retningslinjer for barnehagelærerutdanningen. Kunnskapsdepartementet. https://www. 
uhr.no/temasider/nasjonale-retningslinjer/nasjonale-retningslinjer-forlarerutdanningene/

Malloch, S. \& Trevarthen, C. (2009). Musicality: Communicating the vitality and interests of life. I S. Malloch \& C. Trevarthen (Red.), Communicative musicality (s. 1-10). Oxford University Press.

Marcus, G. F. (2012). Musicality: Instinct or acquired skill? Topics in Cognitive Science, 4(4). https://doi.org/10.1111/j.1756-8765.2012.01220.x

Morin, A. J. S., Scalas, F. L. \& Vispoel, W. (2017). The music self-perception inventory: Development of parallel forms A and B. Psycology of Music, 45 (4), 530-539.

Müllensiefen, D., Gingras, B., Musli, J. \& Stewart, L. (2013). Goldsmiths musical sophistication index (Gold-MSI) v.1.o: Technical report and documentation revision 0.3. PLOS. https://www.gold.ac.uk/media/documents-by-section/ departments/psychology/Gold-MSIv1o_Documentation.pdf

Nielsen, F. V. (1997). Den musikpædagogiske forsknings territorium: Hovedbegreber og distinktioner i genstandsfeltet. I H. Jørgensen, F. V. Nielsen \& B. Olsson (Red.), Nordisk musikkpedagogisk forskning. Årbok 1997 (s. 155-187). Norges musikkhøgskole.

Pio, F. (2006). From musicality towards musicality-bildung: Tracing the birth of the musicological concept Musikalität. I F. V. Nielsen \& S. G. Nielsen (Red.), Nordisk musikkpedagogisk forskning. Årbok 8 (s. 77-90). Norges musikkhøgskole.

Ruismäki, H. \& Tereska, T. (2006). Early childhood musical experiences: Contributing to pre-service elementary teachers's self-concept in music and success in music education (during student age). European Early Childhood Educational Research Journal, 14(1), 113-130, https://doi. org/10.1080/13502930685209841

Schei, T. B. (2011). Kan stemmeskam overvinnes? Om helsefremmende aspekter ved profesjonelle sangeres identitetsarbeid. I K. Stensæth \& L. O. Bonde (Red.), Musikk, helse, identitet (s. 85-105). Norges musikkhøgskole.

Seashore, C. E. (1938). Psychology of music. McGraw-Hill.

Small, C. (1998). Music of the common tongue. Calder.

Stern, D. N. (2003). Spedbarnets interpersonlige verden. Gyldendal Akademisk.

Sæther, M. (2019). Musikalsk utvikling - en helhet. I M. Sæther \& E. Angelo (Red.), Barnet og musikken (s. 62-93). Universitetsforlaget.

Vist, T. (2005). I lyden bor barnet, i barnet bor lyden - om små barns forhold til musikk. I G. Haugen, G. Løkken \& M. Rötle (Red.), Småbarnspedagogikk, (s. 75-91). J. W. Cappelen Forlag. 



\title{
Music Teachers' and Administrators' Perspectives on Entrepreneurship in Norwegian Higher Music Education: An Exploratory Pilot Study
}

\author{
Benjamin Toscher \\ Norwegian University of Science and Technology
}

\begin{abstract}
Arts entrepreneurship education has been increasingly offered in Norwegian Higher Music Education (HME) since 2011 (Watne \& Nymoen, 2017). I argue that a teacher's perspective and definition of entrepreneurship influences how they teach the subject. Using a qualitative content analysis approach (Elo \& Kyngäs, 2008; Mayring, 2000), this article explores a small $(n=37)$ pilot survey of administrators and teachers from four institutes of HME in Norway. In addition to mapping respondents' definitions of entrepreneurship to the most influential definitions of entrepreneurship from the literature, I explore their perceptions of the need for entrepreneurship in HME and their prescriptive changes for entrepreneurship education's integration into the curriculum. Respondents most commonly defined entrepreneurship in the "opportunity creation, recognition, and exploitation" sense, with definitions related to "self-employment" and "innovation" being the second and third most common response, respectively. $95 \%$ of respondents perceive a need for entrepreneurship education in HME. Prescribing curricular changes, 57\% of respondents see a need for a more market oriented and entrepreneurial focus in the current curriculum to "some extent", $19 \%$ to a "large extent", $16 \%$ to "a little extent", and $8 \%$ to a "very little extent." Rationale for such changes is further analyzed using Bridgstock's (2013) typology of arts entrepreneurship pedagogical approaches. I conclude by guiding educators and readers to existing knowledge and tools in the literature as they relate to each arts entrepreneurship pedagogical approach - an
\end{abstract}

Citation of this chapter: Toscher, B. (2021). Music Teachers' and Administrators' Perspectives on Entrepreneurship in Norwegian Higher Music Education: An Exploratory Pilot Study. In E. Angelo, J. Knigge, M. Sæther \& W. Waagen (Eds.), Higher Education as Context for Music Pedagogy Research (pp. 323-350). Cappelen Damm Akademisk. https://doi.org/10.23865/noasp.119.ch13

License: CC BY-NC-ND 4.0. 
organization of knowledge that is important given the field's diversity of perspectives and the power an educator has in the subject's implementation.

Keywords: arts entrepreneurship education, higher music education, entrepreneurship education pedagogy, educator perspective

The purpose of this exploratory pilot study is to explore pedagogical perspectives on teaching of entrepreneurship in Norwegian higher music education (HME) through a small pilot survey responded to by 37 music teachers and administrators in Norwegian HME. In this pilot survey, respondents: (a) defined entrepreneurship, (b) rated their perceptions of the need for entrepreneurship courses in the HME curriculum, and (c) prescribed what changes should be made to the curriculum, if they felt to a relatively larger extent that there needed to be a more entrepreneurial focus in the current curriculum. In other words, the respondents provided their pedagogical perspectives in terms of the "what", the "to what extent", and the "how" of entrepreneurship education in HME. Their responses are analyzed using a qualitative content analysis approach (Elo \& Kyngäs, 2008; Mayring, 2000), in which the most influential scholarly definitions of entrepreneurship and Bridgstock's (2013) typology of arts entrepreneurship education are used as templates (Brooks et al., 2015) to map their responses into the existing pedagogical literature. But why should these perspectives be studied? While previous research makes an effort to characterize the perceived needs of entrepreneurship from the perspective of music students (Schediwy et al., 2019; Toscher, 2019; Toscher \& Bjørnø, 2019), it is largely the educator who decides what entrepreneurship is in the context of their classroom and to what extent entrepreneurship should be integrated into the curriculum. So far, research studying this perceived need from the perspective of teachers and administrators in HME, which may be collectively referred to as faculty, is lacking.

But so what? Some may view that entrepreneurship is being increasingly institutionalized into HME as evidenced by its rapid growth in many countries across the world (Beckman, 2005; Schediwy et al., 2019; Watne \& Nymoen, 2017). Yet, there appears to be no standardized curriculum 
for the subject and profoundly different pedagogical approaches (Bridgstock, 2013). If one can agree with the importance of the premise that how an educator defines and interprets a concept influences how they decide to teach it in their educational practice, then differences in various educators' definitions and interpretations of entrepreneurship may be a reason why there are several distinct and profoundly different pedagogical approaches to teaching arts entrepreneurship (Bridgstock, 2013). Even the broader field of entrepreneurship is characterized by a multitude of definitions and perspectives as to what entrepreneurship actually is (Landström et al. 2012). More importantly, the impact of an educator's perspective and subsequent choice of pedagogical approach should not be understated if one assumes that in an HME institutional environment, there may exist constraints in teaching resources, compacted study and degree plans which are already filled with courses, established institutional requirements regarding individual course plans and learning outcomes, and differing perspectives on the place of entrepreneurship in the music curriculum.

Such a pedagogical choice by an educator may not only be influenced by their definitions of entrepreneurship, but also by how they perceive the need of entrepreneurship in the music curriculum, where the subject's integration is rather new when considered against the backdrop of higher music education's $17^{\text {th }}$ century origins (Angelo et al., 2019; Beckman, 2005). While the general consensus in the literature examining the professional lives of working musicians seems to be that some degree of entrepreneurial skills and knowledge are needed in their careers, only recently has research examined how music students perceive such needs and the role entrepreneurship education may play in helping them acquire the skills to meet such needs (Schediwy et al., 2019; Toscher, 2019; Toscher \& Bjørnø, 2019). An understanding of this perception of needs from the perspective of teachers and administrators is important for a few reasons. First, a need may be defined as "the difference between a current and expected or desired state" (McKillip, 1987), and that if something is desired, one arguably has a positive attitude towards it. Further, social psychologist Peter Burke claims that "persons who have a positive attitude toward a particular behavior are seen as more likely to perform that behavior" (Burke, 1991, 
p. 191). Thus, a music student's perceptions of the need for entrepreneurship may arguably influence their subsequent entrepreneurial behavior, including whether or not they would take a course in entrepreneurship if it was optional and not a required course. Using the same logic, I can imagine that an arts educator's behavior in teaching entrepreneurship, including the extent to which they think it should be integrated in the curriculum, may be influenced by their own attitudes and perceived needs of teaching that subject in their educational environment.

Previous research has documented "artists' resistance, politically and methodologically, to the 'entrepreneur' label”, (Bonin-Rodriguez, 2012, p. 9) perhaps due to some cultural connotations of profit-maximization implied by the term entrepreneur (Mulcahy, 2003). Moore (2016) persuasively argues why music educators may be skeptical or reluctant to the "institutionalized push for musical entrepreneurship ... rooted in the discourse and ideals of neoliberalism" (p. 33), an attitude which, in some circumstances, has resulted in the "resistance" of entrepreneurship's integration into the arts curriculum by faculty (Roberts, 2013). Some argue this tension between art and entrepreneurship has to do with conflicting bohemian and entrepreneurial identities - perhaps meaning that artists are not willing to consider themselves to be "entrepreneurs" due a potential conflict in values between money and art, or for entrepreneurship's potential associations with neoliberal political ideology (Eikhof \& Haunschild, 2006; Moore, 2016) - a tension which other education researchers argue should be resolved in order for students to sustain a career in the arts (Wyszomirski \& Chang, 2017). Yet, this tension may be more observable amongst teachers than amongst the students, who may just care about pursuing higher musical education in order to pursue a musical career rather than purely artistic ideals. Brook and Fostaty Young (2019) found that over $72 \%$ of the higher music education alumni they surveyed pursued their studies in HME to prepare for a job in music. Further, given that other empirical research examining the perceptions of musical career identities of 146 music students in the Netherlands revealed that these students do not necessarily experience a tension between entrepreneurial and bohemian "imperatives" (Schediwy et al., 2018, p. 174), it may be particularly interesting to study both this perceived need and 
conceptualization of entrepreneurship from the perspectives of teachers and administrators whom help comprise the artistic context of HME.

But again, so what - why does this all matter? Ultimately, an empirically based articulation of teachers' perspectives which includes "what" entrepreneurship is to them and "to what extent" it should be taught in HME may be useful for other educators whom have been given the assignment to teach arts entrepreneurship and whom can potentially identify with one of these perspectives. Subsequently, they can be directed to existing educational tools, resources, and knowledge for this quickly growing field. In other words, depending on a reader's own "what" and "to what extent" of entrepreneurship, it would be of value to provide some direction to further resources on the particular "how" of teaching arts entrepreneurship. If you are such a reader and you already know what your pedagogical perspective is and what actually needs to be or should be taught when it comes to teaching entrepreneurship in HME, simply skip ahead to table 6 towards the end of this paper to find the organization of resources and literature which may assist in the teaching of the subject.

For others, this article proceeds as follows. First, I briefly discuss the background literature which describes and explains the emergence of entrepreneurship education in HME, alongside the definitional diversity of the term entrepreneurship. I then conduct a thought experiment to demonstrate how different notions of the term entrepreneurship will influence how the subject is taught. I follow by presenting my research questions and method, after which I present the results from a small $(n=37)$ survey of teachers and administrators in Norwegian HME alongside discussion and interpretation of these results. I conclude the paper by guiding both educators and readers to existing knowledge, tools, and resources in the literature as they relate to the various arts entrepreneurship pedagogical approaches examined in this study.

\section{Background Literature}

Research shows that musicians require a set of entrepreneurial skills (Lackeus, 2015) such as networking (Coulson, 2012), recognizing opportunities (Beckman, 2011; van Zuilenburg, 2012), and managing multiple 
professional roles simultaneously (Brown, 2005; Cawsey, 1995) in order to maintain their careers in music. As a potential response, entrepreneurship education has been integrated into the higher arts education curriculum in the United States, Australia, Germany, the Netherlands, and the UK as a possible way to help arts students acquire such skills (Beckman, 2007; Brandenburg \& Roosen, 2016; Pollard \& Wilson, 2014; Thom, 2017). Norway is no exception to this trend, where in higher music education (HME) there are at least 35 courses where entrepreneurship is a stated competency goal and 49 obligatory courses where entrepreneurship is either a minor or main component of the course and that this offering has been growing since 2011 (Watne \& Nymoen, 2017). Despite the growth of this curricular offering, which is commonly referred to as arts entrepreneurship education or sometimes cultural entrepreneurship (Essig, 2016), scholars and educators have a variety of interpretations and definitions of what the concept of arts entrepreneurship actually is (Chang \& Wyszomirski, 2015; Essig \& Guevara, 2016; Hong et al., 2012). Through their discussion about how different definitions of entrepreneurship are used by various actors in the music field, Watne and Nymoen (2017) note that the "music field makes it possible for different definitions of entrepreneurship" (p. 372).

Even the broader research field of entrepreneurship is no stranger to this definitional and interpretational variety of entrepreneurship (see Landström et al. 2012 for an excellent review of the entrepreneurship research field's historical development). The following thought experiment may illustrate how different definitions of entrepreneurship may have a significant pedagogical impact. With 15,919 Google scholar citations as of May 29, 2020, one of the most highly cited definitions of entrepreneurship is offered by Shane and Venkataraman (2000), who define entrepreneurship as the "examination of how, by whom, and with what effects opportunities to create future goods and services are discovered, evaluated and exploited;" they speak primarily about acting upon and recognizing opportunities. Compare this with the definition proposed by Schumpeter (1934), whose notion of the word entrepreneurship relates more closely to innovation and "doing things that are not generally done in the ordinary course of business routine" (Schumpeter, 
1934). To understand how these two distinct definitions might influence pedagogy, let's imagine a teacher in HME has been assigned the task of teaching a course in entrepreneurship. Now let's imagine that this teacher views entrepreneurship in the opportunity sense of the word as defined by Shane and Venkataraman. In this teacher's entrepreneurship course, students are asked to perform an assignment in which they must speak with their social networks, go out into their community, approach people they have never spoken to before and find an opportunity to book a performance gig in their own town within the next two hours. After preparing, promoting, and performing the event, they consider what new opportunities have emerged from it - whether it is connecting with a new audience or perhaps serendipitously meeting a promoter in attendance who wants to book them for another gig. This happens to be an actual entrepreneurship assignment that takes place at the Julliard School in New York City (Beeching, 2016). However, imagine instead this teacher defined entrepreneurship in the innovation sense described by Schumpeter. Based on this view of entrepreneurship, they might ask their students to be innovative and re-imagine, freshen up, and breathe new life into a classical piece of music in a way that it could connect with hip, young, modern audiences. Maybe these students would be assigned Raph Vaughan Williams's Lark Ascending as an example of a piece from the classical repertoire whose performance needed an innovative re-imagining. This teacher would want their students to be entrepreneurial by being innovative, doing new things like incorporating real-time audience feedback mechanisms (like by using Twitter) into the piece's performance, or otherwise creating a new concert experience by combining things which had never been combined before. The above two definitions of entrepreneurship can be further contrasted by Gartner's (1988) own definition - entrepreneurship is simply organization creation or "the process by which new organizations come into existence." If the teacher in our imagined example instead viewed entrepreneurship in this organization creation sense, they might simply have their students learn about the formalities of establishing a legal entity like a corporation or non-profit foundation, keeping records, filing taxes, issuing invoices, and other aspects of administering an organization. 


\section{Questions of "What", "To What Extent", and "How"}

To summarize, I have so far argued that how an educator defines the concept of entrepreneurship may influence how they teach the subject, and that how they perceive the need of the subject may influence to what extent they teach it. It is important to note, however, that I have not argued there should be only one definition of entrepreneurship (the "what" of entrepreneurship in HME) or that there is an objective, optimal extent to which entrepreneurship should be integrated in the HME curriculum (the "to what extent" of entrepreneurship); nor it is the intent of this paper to argue such points. Instead, I submit that these latter questions of normativity are to be decided by the educators themselves based on their own arts entrepreneurship pedagogical perspective, which I define as being comprised of their definitions of entrepreneurship and their perceptions of its need in the curriculum - and that empirical research is lacking which characterizes what these perspectives actually are. Of the limited empirical research, which has explored educator perspectives, some evidence indicates that Norway may be an interesting context to examine these questions in more depth. In their survey of 23 leaders of Norwegian HME institutions, Watne and Nymoen (2017) found that a majority of participants believed musical skills to be more important than entrepreneurial skills when considering their institution's strategic plans for teaching, plans which other research has shown teachers and leaders in Norwegian HME often refer to (Angelo et al., 2019). Yet, "a plurality of the participants admit[ted] that there is a potential for strengthening entrepreneurship teaching at their institutions. One reason given is the challenge of balancing entrepreneurship on one hand and 'pure' music subjects on the other" (p. 367) and that "participants' own associations to the concept of entrepreneurship has an impact on their responses" (p. 381), perhaps because the "music field makes it possible for different definitions of entrepreneurship" (p. 372).

Thus, I have the following research questions:

RQ1. What are music teachers' and administrators' definitions of entrepreneurship in Norwegian HME? 
RQ2. To what extent do music teachers and administrators perceive the need of entrepreneurship in relation to the current HME curricula in Norway?

RQ3. What existing educational tools, resources, and knowledge are available to help teachers teach entrepreneurship in higher music education depending on how they choose to teach it?

\section{Method - Empirical Data}

To answer research questions 1 and 2, a survey was disseminated to music teachers and administrators at institutes of HME in Norway during the spring of 2018. The survey was distributed through a variety of informal and formal channels such as social networks and e-mail lists. The sampling approach may be characterized as a type of nonprobability convenience sampling in which "members of the target population meet certain practical criteria, such as easy accessibility, geographical proximity, availability at a given time, or the willingness to participate are included for the purpose of the study" (Etikan et al., 2016, p. 2). However, this sample was also purposive in the sense that faculty in higher music education were the most appropriate individuals to participate in answering the research questions in this study (Bernard, 2006). The majority of institutes of HME in Norway were approached regarding the survey and respondents from 4 institutes were willing to participate and thirtyseven individuals from faculty responded, with 24 self-reporting their role in their HME institution as a "teacher", 11 as an "administrator", and 2 reporting as both "teacher" and "administrator".

To answer research question 1, respondents were asked to answer the following open-ended question: "How do you define entrepreneurship?" To answer research question 2, respondents were first asked to respond to the following question using a likert-type scale: "To what extent do you see a need for a more market-oriented and entrepreneurial focus in today's curriculum?" Those respondents who answered either "to some extent", "to a large extent", or "to a very large extent" to this question were then asked: "which concrete changes do you think should be done to the curriculum?" This follow-up question was asked to this subset of respondents for the following reasons: first, those teachers who see a greater need (McKillip, 
1987) for entrepreneurship in music education may be more likely to argue or work towards its implementation in the HME curriculum in the future (Burke, 1991); second, such teachers are being directly asked what "concrete changes" they think should be done to the curriculum; and third, these responses may provide further qualitative insight into their arts entrepreneurship pedagogical perspectives. Readers should note that I relate and operationalize the words "entrepreneurship" and "entrepreneurial" in the same way that I relate and operationalize the words "music" and "musical"; the latter is simply the adjective form of the former, which is a noun.

After a discussion of results from research questions 1 and 2, RQ3 is addressed through an organization (via literature search) of some of the existing educational tools, resources, and knowledge available in the literature to orient the reader to relevant information, depending upon their arts entrepreneurship pedagogical perspective.

\section{Method of Analysis}

To analyze the results from research question 1, I use nine definitional themes of entrepreneurship which are listed in Table 1 as a template to analyze and code the respondents' responses. This form of "template analysis" (Brooks et al., 2015) utilizes the same approach other researchers have used to study how music students define entrepreneurship in HME (Toscher \& Bjørnø, 2019), and is based upon a literature review of the most influential and widely cited definitions of entrepreneurship used in both the entrepreneurship (Landström et al., 2012) and arts entrepreneurship research fields. For each of these definitions, table 1 displays the author, the thematic focus of that author's definition, the word-for-word operationalized definition I used to analyze responses, and the full citation from which the definition first appeared in the literature. This table is provided for both the purposes of transparency in my research methodology but also to encourage the reader to familiarize themselves with these definitions (which may be new to them) and to begin contemplating just how different some of these definitions are. If you recall the previous discussion of how the opportunity, innovation, and organization creation definitions of entrepreneurship would affect the teaching of the subject, 


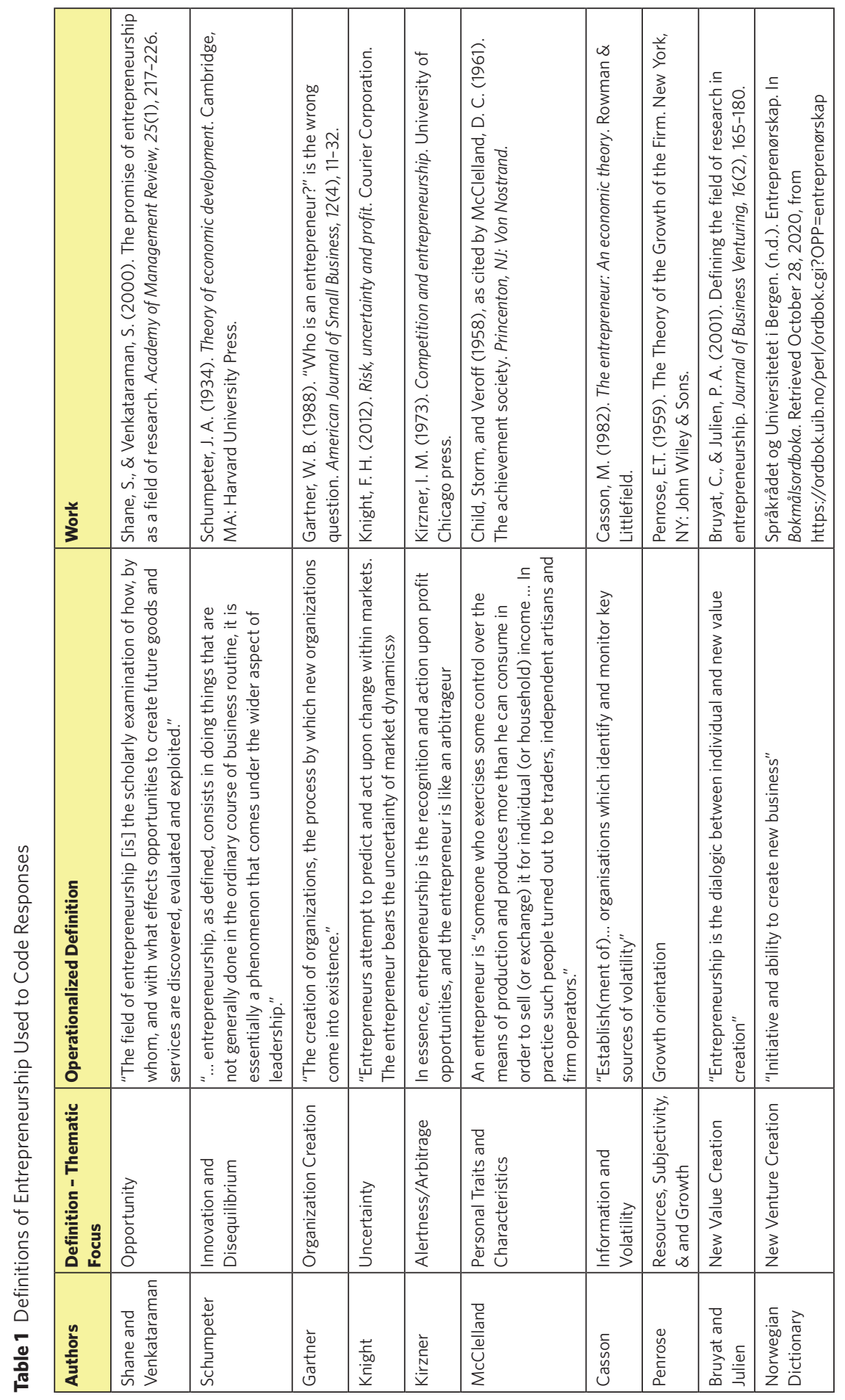


one can begin to consider how the six other definitional themes influence the nature of an assignment in the entrepreneurship classroom.

To analyze the results for research question 2, I first present the descriptive statistics resulting from the responses to the likert-type scale question. I then perform a qualitative content analysis (Elo \& Kyngäs, 2008; Mayring, 2000) of the open-ended responses from respondents who indicated a need for more market-oriented and entrepreneurial focus in the current curriculum to either "some", "large", or "very large" extents. These responses are then coded using Bridgstock's (2013) typology of arts entrepreneurship education approaches as a template. Examples of how responses were coded according to Bridgstock's typology can be found in the right-hand most column of table 5 in the results section. Bridgstock's (2013) effort may represent the most comprehensive typology of arts entrepreneurship education, which could be interpreted as the pedagogical manifestation of the perceived needs of entrepreneurship by those educators who created the courses which form the basis of such a typology. Building on Beckman's (2007) early empirical efforts to understand the pedagogical approaches to arts entrepreneurship, Bridgstock (2013) describes three main approaches to the subject: (1) employability and career self-management, (2) being enterprising, and (3) new venture creation. While the employability and career self-management approach focuses on "the artist's ability to build a sustainable career through recurrently obtaining or creating arts employment, and the skills relating to career self-management" (p. 127), and the being enterprising approach is about "less tangible capabilities such as opportunity recognition, entrepreneurial behavior, or resilience ... the identification or creation of artistic opportunities and exploitation of those opportunities in terms of applying or sharing artistic activity in order to add value of some kind" (p. 126), the new venture creation approach "is a more traditional view which corresponds the most closely to Business School notions of entrepreneurship ... students learn skills and knowledge associated with starting and growing an artistic enterprise, including sales and marketing, legal issues, business strategy and finance" (pp. 125-126).

Finally, to analyze the results for research question 3, I use Bridgstock's typology to organize a list of resources, tools, and knowledge in 
conjunction with recent research from Schediwy et al. (2019). Schediwy et al. have created an inventory of factors as they relate to each type of arts entrepreneurship approach described by Bridgstock and directly address a perceived need for entrepreneurship in HME. This inventory of factors is based on their empirical survey of 167 music students in HME in which they used Bridgstock's typology to identify, articulate, and empirically test 22 concrete factors which determine pedagogical activity; they then surveyed music students to understand music students' perceptions of the need for these factors as they relate to their future careers. While Schediwy et al. applied these factors to the perspectives of students, this study is concerned with these factors as perceived by the music faculty, and is thus concerned with how teachers may practically approach teaching arts entrepreneurship depending upon their own perceptions of the need for the topic in the curriculum and their pedagogical perspective.

\section{Results and Discussion}

In this section, I present and discuss the results from the survey organized by their relation to each specific research question.

\section{$R Q 1$. What are musicteachers' and administrators' definitions of entrepreneurship?}

The results for RQ1 relate to questions of "what" in arts entrepreneurship education, and table 2 shows that the most frequent definition offered by the respondents relates to opportunity (32\%) in the sense proposed by Shane and Venkataraman (2000). This indicates that perhaps amongst the respondents, the term entrepreneurship is not predominantly viewed to be in conflict with aesthetic ideals, such as the notion of "art-for-arts-sake" (Beckman, 2005, p. 21). This conflict may emerge by those teachers and administrators who view entrepreneurship education as simply vocational training, which has been observed to "be a conflict between the mission of liberal arts institutions and entrepreneurship education ... an obstacle" (Beckman, 2007, p. 93). The pedagogical implications of framing entrepreneurship in this opportunity sense should not be understated. First, whereas a teacher's framing of entrepreneurship as strictly "new venture creation" may see students learning relevant information and performing 
tasks relevant for their career (like how to write a grant application or understanding how to set up a legal entity), this information could arguably be learned from books and, as is the case with the trade-offs involved in any course design, taught in lieu of other more experiential activities directly related to recognizing and acting upon opportunities as an artist - something which is arguably relevant for music students who may often need to act as "artist-producers" (Bonin-Rodriguez, 2012) in creating their own flow of sustainable projects and gigs. Indeed, with only $5 \%$ of the respondents defining entrepreneurship in the "new venture creation" sense, it may appear that the majority of respondents are perhaps in agreement with this perspective. Notably, the second most frequently offered definitions relates to "self-employment" (22\%). In related research, this was the most frequently offered definition on a survey of Norwegian music students with approximately $32 \%$ of the respondents defining entrepreneurship in this way (Toscher \& Bjørnø, 2019). It may not be surprising that this is the second most common definition of entrepreneurship in this study, as "employment and career self-management" has been offered as its own type of arts entrepreneurship pedagogy by Bridgstock (2013) due to its observed prevalence in practice. An understanding of career options and the encouragement of students to take ownership over their careers are argued, by Schediwy et al. (2019), to be factors which comprise this pedagogical approach. Unsurprisingly, these important and applicable aspects of career preview have been explored elsewhere in the literature (Bennett \& Bridgstock, 2015), and given the nature of portfolio careers which many artists must maintain (Cawsey, 1995), it may make sense why self-employment was the second most common definition. Further, the third most common definition was in the Schumpeterian sense of "innovation", which may indicate the respondents in general situate the concept of entrepreneurship in a broader sense than simply vocational training. Regardless, the respondents did not uniformly define entrepreneurship in a singular sense, nor do I argue that they should. Instead, I submit that how they define entrepreneurship is important since it will influence how and what they teach. The findings show that there are indeed many different definitions of the term, and that perhaps a first step in making a choice in how to teach the subject is an array of choices, which articulates and 
makes explicit these different perspectives. In order to consider and reexamine how one thinks about a subject, I would argue they first need to expose their own thoughts on the subject. In this sense, the present study makes a contribution to making explicit such a range of options.

Table 2 Presents the results of how the respondent music teachers and administrators defined entrepreneurship

\begin{tabular}{|l|c|c|}
\hline Definition of Entrepreneurship (Author (s)) & \# of Respondents & \% of Sample \\
\hline Self-Employment / Personal Traits (McClelland) & 8 & $22 \%$ \\
\hline Opportunity (Shane and Venkataraman) & 12 & $32 \%$ \\
\hline Business Creation (Norwegian Dictionary) & 3 & $8 \%$ \\
\hline No answer & 3 & $8 \%$ \\
\hline Organization Creation (Gartner) & 4 & $11 \%$ \\
\hline New Value Creation (Bruyat and Julien) & 2 & $5 \%$ \\
\hline Innovation (Schumpeter) & 5 & $14 \%$ \\
\hline
\end{tabular}

Table 2 - Music Teachers' and Administrators' Coded Definitions of Entrepreneurship

RQ2. To what extent do music teachers and administrators perceive the need of entrepreneurship in relation to the current HME curricula in Norway?

The results to RQ2 are summarized in tables 3, 4, and 5. Table 3 presents results which show how respondents perceive the general need of entrepreneurship courses in HME and table 4 elaborates on this perception by showing to what extent respondents' perceive a need for a more market-oriented and entrepreneurial focus in the current HME curriculum. Table 5 further builds upon these perceptions of the extent of need, and displays results for the concrete changes which should be made to the current HME curriculum according to those respondents who perceive a further need for entrepreneurship to "some" or a "large" extent.

The results of RQ2 relate to questions of "what extent" in arts entrepreneurship education, and table 3 shows that a large majority (95\%) of respondents view a need for entrepreneurship courses in Norwegian HME. This result is a piece of evidence which could indicate that the conflict between arts and entrepreneurship described elsewhere in the literature (Bonin-Rodriguez, 2012; Bridgstock, 2013; Moore, 2016) may not be 
a significant issue for the respondents in terms of their view of its need in the curriculum. Watne and Nymoen's (2017) finding that in Norwegian HME there were at least 35 courses where entrepreneurship is a stated competency goal and 49 obligatory courses where entrepreneurship is either a minor or main component of that course further supports this view. They also found that entrepreneurship courses had been increasingly offered since 2011. As seen in table 4, the majority (57\%) perceive there to be a need for a more market-oriented and entrepreneurial focus in the curriculum to "some extent" and 19\% to a "large extent", perhaps indicating that the trend Watne and Nymoen observed may continue into the future. While roughly a quarter $(24 \%)$ of the respondents view the need for more entrepreneurship to a "very little" or "little" extent, the concrete changes prescribed by those who perceive a greater need reveal what type of arts entrepreneurship pedagogical approaches should be implemented. Table 5 displays the distribution of these prescriptive changes using Bridgstock's (2013) typology of arts entrepreneurship pedagogy, with $61 \%$ prescribing career self-management, $7 \%$ prescribing being enterprising, and $14 \%$ prescribing the new venture creation type of arts entrepreneurship pedagogy. Eighteen percent could not be coded to Bridgstock's typology; however, based upon these specific responses, this seems much more likely due to a misunderstanding of the question rather than respondents providing a response which could not be reasonably coded to the typology as it currently is, as opposed to representing a potentially fourth type of pedagogy. Whether there is indeed a fourth type of pedagogy is another interesting question, which could perhaps be answered by performing a thorough analysis of entrepreneurship curricula and course descriptions in HME all over the world. Examples of how these responses were coded are included in table 5.

These results are not particularly surprising when considered in light of the frequency which the "self-employment" definition was provided by respondents. The predominance of this career self-management perspective seems to be consistent with other discussions regarding vocational training in the arts entrepreneurship literature, which again may not be a big surprise. It is also notable that despite "opportunity" being the most commonly provided definition of entrepreneurship by respondents, the 
pedagogical approach in which the idea of opportunity recognition and action arguably most closely fits - the "being enterprising" approach was prescribed the least frequently. One can speculate in many different directions as to why this is the case. But I will offer a few potential ideas. First, perhaps in the field of arts entrepreneurship education, where to many administrators the "practical experience of potential instructors" is balanced against their "academic legitimacy" (Beckman, 2007 p. 94), such educators may lack to a certain extent formal pedagogical training related to the "being enterprising" approach. This approach closely resembling other experiential entrepreneurship education with origins in the disciplines of business and economics (Cooper et al., 2004; Neck \& Corbett, 2018). Alternatively, it could be these respondents are personally aware of the real and observed demands of being a self-employed musician in a portfolio career that awaits students after they graduate. This reality might simply weigh more heavily on the minds' of these respondents, and that the correspondent career self-management approach is perhaps more concrete than the "less tangible" (Bridgstock, 2013, p. 126) approach of being enterprising, thus arguably more appropriate to address what some may call a HME in "crisis" (Orning, 2017).

While I cannot conclusively argue for a new typology of arts entrepreneurship pedagogical perspectives, various responses in the survey allude to the broad spectrum of views when it comes to the suitability and extent entrepreneurship's integration in HME. For example, while one respondent said that "we need to assure that entrepreneurial thinking is a common thread throughout all the music performance subjects. [Entrepreneurship] has to be integrated into other subjects to a greater extent rather than replacing them." Another said there should be a "big focus on creating your own projects/brands, and give students knowledge and tools to maintain/administer these." However, other respondents took a rather different perspective. One noted that "I think it is sad such a [entrepreneurship] course is necessary in music education, I think to be a musician should be the only thing necessary in a music education," and another that "I am also unsure to which degree it should be up to the educational institutions to take care of this knowledge. As I said in the previous answer, I think it is up to the students themselves, which 
has a lot of positive sides." This could be interpreted as evidence of the previously documented debates regarding entrepreneurship's place in the arts curriculum (Bonin-Rodriguez, 2012; Moore, 2016; Roberts, 2013), but more importantly, it points to the diversity, importance and power of the individual teacher's perspective. Further, this qualitative result also tells a somewhat different story than the quantitative results from RQ1 and RQ2 discussed earlier - a subtle narrative difference which perhaps reinforces the importance and influence of a single individual teacher's autonomy and perspective on the matter. It is the teacher, after all, who has a regular practice of meeting the student during the coursework.

Table 3 Respondents (Teachers and Administrators) Perceptions of the Need for Entrepreneurship Courses in Norwegian HME

\begin{tabular}{|c|c|c|}
\hline \multicolumn{2}{|c|}{ "Is there a need for music-oriented entrepreneurship courses at } \\
institutes of higher education in Norway?" \\
\hline & 35 & $\%$ of Sample \\
\hline Yes & 2 & $95 \%$ \\
\hline No & & $5 \%$ \\
\hline
\end{tabular}

Table 4 Respondents (Teachers and Administrators) Perceptions of the Extent of the Need for A More Market-Oriented and Entrepreneurial Focus in the Current Curriculum

\begin{tabular}{|l|c|c|}
\hline \multicolumn{3}{|c|}{$\begin{array}{c}\text { "To what extent do you see a need for a more market-oriented and } \\
\text { entrepreneurial focus in today's curriculum?" }\end{array}$} \\
\hline Extent of Further Need & \# of Respondents & $\%$ of Sample \\
\hline To a very little extent & 3 & $8 \%$ \\
\hline To a little extent & 6 & $16 \%$ \\
\hline To some extent & 21 & $57 \%$ \\
\hline To a large extent & 7 & $19 \%$ \\
\hline
\end{tabular}

RQ3. What existing educational tools, resources, and knowledge are available to help teachers teach entrepreneurship in higher music education depending on how they choose to teach it?

Table 6 presents a list of factors from Schediwy et al.'s (2019) Perceived Need of Entrepreneurship Education Scale. This scale is comprised of a list of factors which are then organized into one of 3 arts entrepreneurship education pedagogical types described by Bridgstock (2013). I then present, in the 
Table 5 Responses by Surveyed Teachers and Administrators as to What Concrete Changes Should be Made to Current Curriculum

\section{Those who answered there is a further need for entrepreneurship to 'some extent', to a 'large extent', were asked "what concrete changes should be made?" Responses coded to Bridgstock, 2013}

\begin{tabular}{|c|c|c|c|}
\hline $\begin{array}{l}\text { Arts } \\
\text { Entrepreneurship } \\
\text { Pedagogical } \\
\text { Approach } \\
\text { (Bridgstock, 2013) }\end{array}$ & $\begin{array}{c}\text { \# of } \\
\text { Respondents }\end{array}$ & $\%$ & Example Responses \\
\hline $\begin{array}{l}\text { Career Self } \\
\text { Management }\end{array}$ & 17 & $61 \%$ & $\begin{array}{l}\text { R13: "Give the students various practical } \\
\text { experiences during their bachelor studies, so } \\
\text { that they come in contact with working life } \\
\text { and the music field. To a greater extent include } \\
\text { project based courses which give students } \\
\text { experience with entrepreneurial thinking which } \\
\text { is relevant for musicians." -- R12: "I Don't know. } \\
\text { I think it is sad that such a subject is necessary } \\
\text { in a music education, because I think to be a } \\
\text { musician should be the only important thing } \\
\text { in the education. I also see however that a } \\
\text { certain level of knowledge about the market and } \\
\text { entrepreneurship can be necessary to be able to } \\
\text { meet the working life." }\end{array}$ \\
\hline Being Enterprising & 2 & $7 \%$ & $\begin{array}{l}\text { R23: "Entrepreneurship is necessary but it is } \\
\text { almost receiving too much focus. It shouldn't be } \\
\text { the new religion. Teaching in entrepreneurship } \\
\text { should have with it the philosophical and } \\
\text { ideological foundations that entrepreneurial } \\
\text { thought builds upon." -- R6: "We have to ensure } \\
\text { that entrepreneurial thinking goes as a 'common } \\
\text { thread' through all music performance courses. It } \\
\text { has to be integrated in other courses to a greater } \\
\text { extent rather than becoming it's own subject." }\end{array}$ \\
\hline $\begin{array}{l}\text { New Venture } \\
\text { Creation }\end{array}$ & 4 & $14 \%$ & $\begin{array}{l}\text { R25: "Greater focus on making your own } \\
\text { projects/brands, and giving the students the } \\
\text { knowledge and tools to manage/adminster } \\
\text { these." -- R35: "Involve the students more in } \\
\text { concert production: make an interesting concert } \\
\text { program, plan a tour, run public relations, } \\
\text { promote ideas and concepts around the concert } \\
\text { to the audience." }\end{array}$ \\
\hline $\begin{array}{l}\text { Could not be } \\
\text { coded // } \\
\text { No answer }\end{array}$ & 5 & $18 \%$ & $\begin{array}{l}\text { R30: "I base my choice here on statements I } \\
\text { have heard from students. I know too little about } \\
\text { teaching and teaching components to suggest } \\
\text { changes or improvements." -- R19: "We should } \\
\text { prepare for more study programs where students } \\
\text { that don't fit into classical, jazz or folk music can } \\
\text { also be adapted for the teaching." }\end{array}$ \\
\hline
\end{tabular}


Table 6 Existing Knowledge, Tools, and Resources Addressing Specific Perceived Needs for Entrepreneurship Education in HME

\begin{tabular}{|c|c|}
\hline $\begin{array}{l}\text { Factor from Perceived Need of } \\
\text { Entrepreneurship Education Scale } \\
\text { (adapted from Schediwy et al., 2019) }\end{array}$ & $\begin{array}{l}\text { Promising Existing Resource Which Explores This } \\
\text { Factor in Depth }\end{array}$ \\
\hline \multicolumn{2}{|c|}{ Employment and Career Self-Management } \\
\hline Self-confidence & $\begin{array}{l}\text { Bandura, A. (2010). Self-efficacy. The Corsini } \\
\text { encyclopedia of psychology, 1-3. }\end{array}$ \\
\hline $\begin{array}{l}\text { Dealing with challenges in music } \\
\text { industry }\end{array}$ & $\begin{array}{l}\text { Vaag, J., Giæver, F., \& Bjerkeset, O. (2014). Specific } \\
\text { demands and resources in the career of the } \\
\text { Norwegian freelance musician. Arts \& Health, 6(3), } \\
\text { 205-222. }\end{array}$ \\
\hline Being flexible and adaptive in career & $\begin{array}{l}\text { Johnson, S. (2015). Who moved my cheese? Random } \\
\text { House. }\end{array}$ \\
\hline Encouragement in ownership of career & $\begin{array}{l}\text { Hall, D. T. (2004). The protean career: A quarter- } \\
\text { century journey. Journal of vocational behavior, 65(1), } \\
1-13 .\end{array}$ \\
\hline Career options in music sector & $\begin{array}{l}\text { Baskerville, D., \& Baskerville, T. (2018). Music } \\
\text { business handbook and career guide. Sage } \\
\text { Publications. }\end{array}$ \\
\hline Managing uncertainty and taking risk & $\begin{array}{l}\text { "Strategies for Dealing with Uncertainty and Risk", } \\
\text { pp. 39-43. Anderton, C., Dubber, A., \& James, M. } \\
\text { (2012). Understanding the music industries. Sage. }\end{array}$ \\
\hline \multicolumn{2}{|c|}{ Being Enterprising } \\
\hline $\begin{array}{l}\text { Identifying and recognizing } \\
\text { opportunities }\end{array}$ & $\begin{array}{l}\text { Saks, N. T., \& Gaglio, C. M. (2002). Can opportunity } \\
\text { identification be taught? Journal of Enterprising } \\
\text { Culture, } 10(04), 313-347 \text {. }\end{array}$ \\
\hline Innovative thinking & $\begin{array}{l}\text { Brousseau, K. R., Driver, M. J., Eneroth, K., \& Larson, } \\
\text { R. (1996). Career pandemonium: Realigning } \\
\text { organizations and individuals. Academy of } \\
\text { Management Perspectives, } 10(4), 52-66 .\end{array}$ \\
\hline $\begin{array}{l}\text { "What record labels think is good } \\
\text { music" }\end{array}$ & $\begin{array}{l}\text { Essling, Christian and Koenen, Johannes and } \\
\text { Peukert, Christian, Competition for Attention } \\
\text { in the Digital Age: The Case of Single Releases } \\
\text { in the Recorded Music Industry (May 22, } \\
\text { 2017). Information Economics and Policy, } \\
\text { Forthcoming. Available at SSRN: https://ssrn.com/ } \\
\text { abstract=2444708 or http://dx.doi.org/10.2139/ } \\
\text { ssrn.2444708 }\end{array}$ \\
\hline $\begin{array}{l}\text { Self promotion to record labels, } \\
\text { publishers, and syncing services }\end{array}$ & $\begin{array}{l}\text { Powers, D. (2011). Bruce Springsteen, rock criticism, } \\
\text { and the music business: Towards a theory and } \\
\text { history of hype. Popular Music and Society, 34(02), } \\
\text { 203-219. }\end{array}$ \\
\hline "What music journalists care about" & $\begin{array}{l}\text { Kearney, S. A. (2010). Could the professional } \\
\text { music journalist vanish in the digital age URL: } \\
\text { www. clearmindedcreative. com/wp-content/ } \\
\text { uploads/2011/04/Could-the-Professional-Music- } \\
\text { Journalist-Vanish.pdf. }\end{array}$ \\
\hline
\end{tabular}




\begin{tabular}{|c|c|}
\hline $\begin{array}{l}\text { Factor from Perceived Need of } \\
\text { Entrepreneurship Education Scale } \\
\text { (adapted from Schediwy et al., 2019) }\end{array}$ & $\begin{array}{l}\text { Promising Existing Resource Which Explores This } \\
\text { Factor in Depth }\end{array}$ \\
\hline $\begin{array}{l}\text { Understanding audience preference } \\
\text { and behavior }\end{array}$ & $\begin{array}{l}\text { Participations Journal of Audience \& Reception } \\
\text { Studies https://www.participations.org/ }\end{array}$ \\
\hline Developing audience & $\begin{array}{l}\text { Beeching, A. M. (2016). Who is audience? Arts and } \\
\text { Humanities in Higher Education, 15(3-4), 395-400. }\end{array}$ \\
\hline Promoting to journalists & $\begin{array}{l}\text { Waters, R. D., Tindall, N. T., \& Morton, T. S. (2010). } \\
\text { Media catching and the journalist-public relations } \\
\text { practitioner relationship: How social media are } \\
\text { changing the practice of media relations. Journal of } \\
\text { Public Relations Research, 22(3), 241-264. }\end{array}$ \\
\hline \multicolumn{2}{|c|}{ New Venture Creation } \\
\hline Managerial finance & $\begin{array}{l}\text { Warren, C., Reeve, J. M., \& Duchac, J. (2013). } \\
\text { Financial \& managerial accounting. Cengage Learning. } \\
\text { (`The applicability of law varies jurisdiction by } \\
\text { jurisdiction, or country by country; so educators } \\
\text { are advised to find a resource which applies to their } \\
\text { jurisdiction/country.) }\end{array}$ \\
\hline Business Strategy & $\begin{array}{l}\text { Sarasvathy, S. D. (2001). Causation and effectuation: } \\
\text { Toward a theoretical shift from economic inevitability } \\
\text { to entrepreneurial contingency. Academy of } \\
\text { management Review, 26(2), 243-263. }\end{array}$ \\
\hline Marketing & $\begin{array}{l}\text { O'Reilly, D., Larsen, G., Kubacki, K., \& Larsen, G. } \\
\text { (2013). Music, markets and consumption. Oxford: } \\
\text { Goodfellow Publishers Limited. }\end{array}$ \\
\hline Starting a business & $\begin{array}{l}\text { Educators are advised to find a resource which is } \\
\text { suitable for your jurisdiction/country/state regarding } \\
\text { incorporation of a business. }\end{array}$ \\
\hline Legal issues in the music industry & $\begin{array}{l}\text { Stim, R. (2018). Music law: How to run your band's } \\
\text { business. Nolo. ( }{ }^{\star} \text { The applicability of law varies } \\
\text { jurisdiction by jurisdiction, or country by country; } \\
\text { so educators are advised to find a resource which } \\
\text { applies to their jurisdiction/country) }\end{array}$ \\
\hline Writing grant applications & $\begin{array}{l}\text { DeVereaux, C. (2015). Fund-Raising and Grant- } \\
\text { Writing Basics for Arts Managers. The Arts } \\
\text { Management Handbook: New Directions for Students } \\
\text { and Practitioners } \\
\text { Gamble, J. R., Brennan, M., \& McAdam, R. (2017). A } \\
\text { rewarding experience? Exploring how crowdfunding } \\
\text { is affecting music industry business models. Journal } \\
\text { of business research, 70, 25-36. }\end{array}$ \\
\hline Selling music & $\begin{array}{l}\text { Peter Tschmuck's Music Business Research article } \\
\text { database is a comprehensive resource which contains } \\
\text { many articles related to selling music in the music } \\
\text { industry, as well as other factors listed in this table: } \\
\text { https://musicbusinessresearch.wordpress.com/ } \\
\text { article-database/ (Accessed January 23, 2020) }\end{array}$ \\
\hline
\end{tabular}


right hand column, promising existing resources which explores these factors in greater depth and could be used as an educational tool, resource, or record of knowledge to help teachers of entrepreneurship in higher music education, depending on which factor they perceive to be important and which type of arts entrepreneurship pedagogy they embrace.

Finally, while it is not the aim of this paper to thoroughly examine such individual teacher autonomy nor to argue for the importance of such autonomy, table 6 does provide existing knowledge, tools, and resources which address specific perceived needs for entrepreneurship education in HME. The intention behind this table is to direct the reader (who may perhaps be a teacher interested in arts entrepreneurship education) to existing resources and knowledge, and allow the reader to direct themselves to those resources depending upon how they perceive the need of entrepreneurship in music education, and as such, respects their autonomy. The list is not exhaustive, and is merely a starting point for further study.

\section{Limitations}

This study has a few limitations. First, despite that respondents provide their own definitions and perceptions of the need for entrepreneurship in HME, this may not be a perfect proxy for understanding how those who teach entrepreneurship in these institutional contexts actually do so in practice. In the future, a case study could be conducted with a purposeful sample of the teachers actually teaching entrepreneurship at these institutions in order to study their perspectives in greater depth. Second, a future study could benefit from both building on some of the initial findings from this exploratory pilot survey in order to build a refined survey instrument and increase the number of respondents. While there were thirty-seven respondents for the survey used in this study, there are many more teachers and administrators working in HME - meaning this number of respondents could be seen as low. This study has not attempted to make statistical predictions to larger populations or to demonstrate any causality or correlative relationship - thus increasing the total number of respondents in a future study could help further characterize the perspectives of those teaching in Norwegian HME. Further, my nonprobability 
sampling approach in this study could be considered convenience sampling (Etikan et al., 2016), thus the findings are limited to the samples themselves, rather than as representative of a broader population (such as, for example, the entirety of teachers in higher music education in either Norway or the entire world) due to uncertainties surrounding generalizability. In convenience samples as in this study, participation is to a large extent based on whom I had access to and whom was willing to participate in a study, thus raising the prospect that those participants who feel strongly about an issue may be the individuals more likely to participate (Sousa et al., 2004). This is a potential response bias which should be recognized as a limitation. Third, besides respondents' self-reporting as either a "teacher" or "administrator", this study does not make use of any other information which could further describe respondents' roles and responsibilities within their educational institution. Future studies could examine their perspectives on entrepreneurship based on a more granular analysis of these varying roles and responsibilities, and whether there are any interesting differences between such perspectives or between teachers and administrators. This type of analysis, however, was not the aim of this study. Finally, it should be noted that the empirical context of this study is in Norwegian HME, and that there exists a diversity of socio-economic and cultural contexts throughout the world. In turn, various endogenous aspects of such cultural contexts may have an impact on this study's findings or impacts on a future study, if it was conducted in a different socio-economic context. For example, there could be significant differences in cultural policy and the perspectives on the roles of both the market and the state as a source for finance or economic stimulus in the professional lives of musicians when comparing contexts such as the USA and Norway. As such, the reader is encouraged to consider the context of this study, and it may be of interest in future studies to replicate this study's approach in a variety of different contexts.

\section{Conclusion}

This study has empirically explored music teachers' and administrators' perspectives on entrepreneurship in Norwegian higher music education - 
in particular questions related to the "what", "to what extent", and "how" of entrepreneurship in HME. Through a small survey, the results indicate that the most common definitions of entrepreneurship relate to the "opportunity", "self-employment" and "innovation" definitions of the word - indicating the respondents do not view entrepreneurship as simply business creation, but frame the concept a bit more broadly as it relates to a life living, working, and creating as a musician. However, while $95 \%$ of respondents perceive a need for entrepreneurship courses in the HME curriculum and $76 \%$ perceive that the current curriculum needs a more market-oriented and entrepreneurial focus to either "some" or a "large extent", $61 \%$ of these respondents think such changes should be implemented through what may be characterized as the career self-management type of arts entrepreneurship pedagogy. The tendency to prescribe this type of pedagogical approach most frequently, despite the prevalence of the "opportunity" definition offered by respondents and that "opportunity" most closely relates to the competing being enterprising approach, is an interesting finding. One can further question whether this is due to a lack of formal training or familiarity in experiential education pedagogy associated with the being enterprising approach in arts entrepreneurship pedagogy; or whether the more immediate, practical concerns of the likely realities of self-employment/portfolio careers faced by students upon graduation may explain this notable discrepancy. Regardless, through the examination of the diversity of perspectives of entrepreneurship in HME, the importance and influence of the individual educator's perspective and pedagogical autonomy is highlighted amidst what some may call the increasing institutionalization of entrepreneurship into HME as interpreted by its recent growth. The question of how and what should be taught is a normative inquiry which is not the aim of this chapter, and is perhaps better addressed in a broader analysis of educational policy and what the goals of HME should be. Irrespective, an evidence-based investigation which might include an examination of identified needs from professional musicians within a given socio-economic context or the measured learning outcomes of pedagogical interventions, may be a significant contribution to the study of what and how entrepreneurship in HME should be taught. But for now, a list of resources related to the 
teaching of entrepreneurship in the context of HME - depending on an individual's own arts entrepreneurship pedagogical perspective - is provided in an effort to assist those in this quickly growing field.

\section{References}

Angelo, E., Varkøy, Ø., \& Georgii-Hemming, E. (2019). Notions of mandate, knowledge and research in norwegian classical music performance studies. Journal for Research in Arts and Sports Education, 3(1), 78-10o. https://doi. org/10.23865/jased.v3.1284

Beckman, G. D. (2005). The entrepreneurship curriculum for music students: Thoughts towards a consensus. College Music Symposium, 45(2005), 13-24. http:// www.jstor.org/stable/10.2307/40374517

Beckman, G. D. (2007). "Adventuring” arts entrepreneurship curricula in higher education: An examination of present efforts, obstacles, and best practices. Journal of Arts Management Law and Society, 37(2), 87-112. https://doi. org/10.3200/JAML.37.2.87-112

Beckman, G. D. (2011). Disciplining arts entrepreneurship education: A call to action. In G. Beckman (Ed.), Disciplining the arts: Teaching entrepreneurship in context (pp. 25-33). Rowman and Littlefield Education.

Beeching, A. M. (2016). Who is audience? Arts and Humanities in Higher Education, 15(3-4), 395-40o. https://doi/10.1177/147402221664739o

Bennett, D., \& Bridgstock, R. (2015). The urgent need for career preview: Student expectations and graduate realities in music and dance. International Journal of Music Education, 33(3), 263-277. https://doi.org/10.1177/0255761414558653

Bernard, H. R. (2006). Research methods in anthropology: Qualitative and quantitative approaches (4th ed.). Rowman and Littlefield.

Bonin-Rodriguez, P. (2012). What's in a name? Typifying artist entrepreneurship in community based training. Artivate: A Journal of Entrepreneurship in the Arts, 1(1), 9-24.

Brandenburg, S., \& Roosen, T. (2016). Toward an adapted business modeling method to improve entrepreneurial skills among art students. A Journal of Entrepreneurship in the Arts, 5(1), 25-33.

Bridgstock, R. (2013). Not a dirty word: Arts entrepreneurship and higher education. Arts and Humanities in Higher Education, 12(2-3), 122-137. https://doi. org/10.1177/1474022212465725

Brook, J., \& Fostaty Young, S. (2019). Exploring post-degree employment of recent music alumni. International Journal of Music Education, 37(1), 142-155. https://doi. org/10.1177/0255761418821165 
Brooks, J., McCluskey, S., Turley, E., \& King, N. (2015). The utility of template analysis in qualitative psychology research. Qualitative Research in Psychology, 12(2), 202-222. https://doi.org/10.1080/14780887.2014.955224

Brown, R. (2005). Performing arts creative enterprise: Approaches to promoting entrepreneurship in arts higher education. The International Journal of Entrepreneurship and Innovation, 6(3), 159-167. https://doi.org/10.5367/ oooooooo54662836

Burke, P. J. (1991). Attitudes, behavior, and the self. In J. A. Howard \& P. L. Callero (Eds.), Self-society dynamic: Cognition, emotion, and action (pp. 189-208). Cambridge University Press.

Cawsey, T. (1995). The portfolio career as a response to a changing job market. Journal of Career Planning and Employment, 56(1), 41-46.

Chang, W. J., \& Wyszomirski, M. (2015). What is arts entrepreneurship? Tracking the development of its definition in scholarly journals. Artivate: A Journal of Entrepreneurship in the Arts, 4(2), 11-31. https://doi.org/10.34053/artivate.4.2.0011

Cooper, S., Bottomley, C., \& Gordon, J. (2004). Stepping out of the classroom and up the ladder of learning an experiential learning approach to entrepreneurship education. Industry and Higher Education, 18(1), 11-22.

Coulson, S. (2012). Collaborating in a competitive world: Musicians' working lives and understandings of entrepreneurship. Work, Employment and Society, 26(2), 246-261. https://doi.org/10.1177/0950017011432919

Eikhof, D. R., \& Haunschild, A. (2006). Lifestyle meets market: Bohemian entrepreneurs in creative industries. Creativity and Innovation Management, 15(3), 234-241. https://doi.org/10.1111/j.1467-8691.2006.00392.x

Elo, S., \& Kyngäs, H. (2008). The qualitative content analysis process. Journal of Advanced Nursing, 62(1), 107-115. https://doi.org/10.1111/j.1365-2648.2007.04569.x

Essig, L., \& Guevara, J. (2016). A landscape of arts entrepreneurship in US higher education. https://herbergerinstitute.asu.edu/sites/default/files/a_landscape_of_ arts_entrepreneurship_in_us_higher_education_o.pdf

Etikan, I., Musa, S. A., \& Alkassim, R. S. (2016). Comparison of convenience sampling and purposive sampling. American Journal of Theoretical and Applied Statistics, 5(1), 1. https://doi.org/10.11648/j.ajtas.20160501.11

Gartner, W. B. (1988). "Who is an entrepreneur?" is the wrong question. American Journal of Small Business, 12(4), 11-32.

Hong, C., Essig, L., \& Bridgstock, R. (2012). The enterprising artist and the arts entrepreneur: emergent pedagogies for new disciplinary habits of mind. In N. Chick, A. Haynie, \& R. Gurung (Eds.), Exploring more signature pedagogies: Approaches to teaching disciplinary habits of mind (pp. 68-84). Stylus.

Lackeus, M. (2015). Entrepreneurship in education: What, why, when, how. Background Paper for OECD-LEED., 1-45. https://www.oecd.org/cfe/leed/ 
BGP_Entrepreneurship-in-Education.pdf\%oAhttp://www.oecd.org/cfe/leed/ BGP_Entrepreneurship-in-Education.pdf

Landström, H., Harirchi, G., \& Åström, F. (2012). Entrepreneurship: Exploring the knowledge base. Research Policy, 41(7), 1154-1181. https://doi.org/10.1016/j. respol.2012.03.009

Mayring, P. (2000). Qualitative content analysis. Forum: Qualitative Social Research, $1(2)$.

McKillip, J. (1987). Need analysis: Tools for the human services and education (applied social research methods). Sage Publications.

Moore, A. (2016). Neoliberalism and the musical entrepreneur. Journal of the Society for American Music, 1o(1), 33-53. https://doi.org/10.1017/S175219631500053X

Mulcahy, K. V. (2003). Entrepeneurship or cultural darwinism? Privatization and American cultural patronage. The Journal of Arts Management, Law, and Society, 33(3), 165-184.

Neck, H. M., \& Corbett, A. C. (2018). The scholarship of teaching and learning entrepreneurship. Entrepreneurship Education and Pedagogy, 1(1), 8-41.

Orning, T. (2017). If higher music education is in crisis, how do we solution ? Music \& Practice, 3.

Pollard, V., \& Wilson, E. (2014). The "entrepreneurial mindset" in creative and performing arts higher education in Australia. Artivate: A Journal of Entrepreneurship in the Arts, 3(1), 3-22. https://doi.org/10.1234/artivate.v3i1.67

Roberts, J. S. (2013). Infusing entrepreneurship within non-business disciplines: Preparing artists and others for self-employment and entrepreneurship. Artivate: A Journal of Entrepreneurship in the Arts, 1(2), 53-63.

Schediwy, L., Bhansing, P. V, Loots, E., \& Group, F. (2018). Young musicians' career identities: Do bohemian and entrepreneurial career identities compete or cohere? Creative Industries Journal, 11(2), 174-196. https://doi.org/10.1080/17510694.2018.1 489197

Schediwy, L., Loots, E., \& Bhansing, P. (2019). With their feet on the ground: A quantitative study of music students' attitudes towards entrepreneurship education students' attitudes towards entrepreneurship education. Journal of Education and Work, 31(7-8), 611-627. https://doi.org/10.108o/13639080.2018.156216o

Schumpeter, J. (1934). The theory of economic development. Harvard University Press.

Shane, S., \& Venkataraman, S. (2000). The promise of entrepreneurship as a field of research. Academy of Management Review, 25(1), 217-226.

Sousa, V. D., Zauszniewski, J. A., \& Musil, C. M. (2004). How to determine whether a convenience sample represents the population. Applied Nursing Research, 17(2), 130-133. https://doi.org/10.1016/j.apnr.2004.03.003

Thom, M. (2017). Arts entrepreneurship education in the UK and Germany. Education + Training, 59(4), 406-426. https://doi.org/10.1108/ET-05-2016-0o89 
Toscher, B. (2019). The skills and knowledge gap in higher music education: An exploratory empirical study. International Journal of Education and the Arts. http://doi.org/10.26209/ijea21n10

Toscher, B., \& Bjørnø, A. M. (2019). Music students' definitions, evaluations, and rationalizations of entrepreneurship. The Journal of Arts Management, Law, and Society, 49(6), 389-412. https://doi.org/10.1080/10632921.2019.1646178

Van Zuilenburg, P. L. (2012). Personality traits of successful music entrepreneurs. Acta Academica, 45(1), 100-118.

Watne, Å., \& Nymoen, K. (2017). Entreprenørskap i høyere norsk musikkutdanning [Entrepreneurship in Norwegian higher music education]. In Ø. Varkøy, E.

Georgii-Hemming, A. Kallio, \& F. Pio (Eds.), Nordic Research in Music Education, Yearbook 18, 367-385. http://hdl.handle.net/11250/2490527

Wyszomirski, M., \& Chang, W. J. (2017). Professional self-structuration in the arts: Sustaining creative careers in the 21st century. Sustainability (Switzerland), 9(6), 1-2o. https://doi.org/10.339o/su9061035 


\title{
The Discursive Terms of Music/Teacher Education at Four Higher Educational Institutions
}

\author{
Elin Angelo
}

Norwegian University of Science and Technology

Jens Knigge

Nord University

Morten Sæther

Queen Maud University College of Early Childhood Education

\section{Wenche Waagen}

Norwegian University of Science and Technology

\begin{abstract}
In this chapter, we examine how music/teacher education is represented on the websites of four Norwegian institutions that offer diverse kinds of music/teacher education at the BA, MA, and PhD levels and that offer qualifications for all types of music teaching professions in Norway. These four cases serve as examples of the main traditions of music/teacher educations in the Nordic area, with distinctive differences in their notions of music, pedagogy, professional orientation, and research. The analysis is theoretically grounded in Foucault's concepts of power/knowledge and governmentality. The findings suggest, on the one hand, considerable variations among the institutions and, on the other hand, similarities in how the representations operate in a range of steering techniques in the ways that these education programs, orientations, groups, and individuals are portrayed. The concluding discussion questions the power/knowledge constructions that provide authority to the dominating discourses, critically pointing to some effects that diverse representations might have for positions, ambitions, and individuals. Getting the diverse communities of music/teacher
\end{abstract}

Citation of this chapter: Angelo, E., Knigge, J., Sæther, M. \& Waagen, W. (2021). The Discursive Terms of Music/Teacher Education at Four Higher Educational Institutions. In E. Angelo, J. Knigge, M. Sæther \& W. Waagen (Eds.), Higher Education as Context for Music Pedagogy Research (pp. 351-385). Cappelen Damm Akademisk. https://doi.org/10.23865/noasp.119.ch14

License: CC BY-NC-ND 4.0. 
educations to communicate seems imperative to evolve more reflexive, conscious, and participative music/teacher education programs in the $21^{\text {st }}$ century.

Keywords: music teacher education, higher music education, website analyses, governmentality, power/knowledge

Music/teacher education in Norway is located in both higher music education (e.g., music academies) and in teacher education (at universities and colleges) institutions. These institutions are built on numerous traditions, foregrounding variations of music and modes of music education, teacher education and pedagogy, or the traditions combining these. The relation between music/teacher education and diverse music teacher professions in Nordic countries was previously identified to follow specific paths: universities educated teachers for upper secondary school, music conservatories educated teachers for music schools, and teacher education programs educated teachers for compulsory school (Nielsen, 2001). Because of extensive merging and collaboration in vocational fields and in the field of higher education, these paths are no longer as distinct (Aglen \& Karlsen, 2017; Eidsvaag \& Angelo, 2021; Holgersen \& Holst, 2020; Nielsen, 2010). Today, musicians, teachers, and music teachers might combine a range of vocational tasks at the intersection of performing and teaching, correspondingly music teacher qualifications can be earned through many routes. A considerable body of discourse-oriented research has examined these fields, focusing on music teachers' practices and negotiations of professional identity and expertise (Ericsson \& Lindgren, 2011; Jordhus-Lier, 2018; Krüger, 2000; Nerland, 2003; Mills, 2004). Internationally, there is a growing interest in evolving music teacher education programs to responsibly and inclusively embrace cultural, contextual, and local diversity (Benedict \& Schmidt, 2014; Bowman, 2007; Kaschub \& Smith, 2014). While the diverse music education practices in schools and society merge in the vocational field, this merging has not necessarily influenced the different music teacher programs. For example, although generalist music teacher education seems to train teachers to be competent in classroom management and group activities as singing and dancing, specialist music teacher education leads to practices of nurturing 
individual skills in instruments, composing, and listening (Sætre, 2014, 2018). Music teaching seems to a great extent to be personally conducted, dependent on the individual teacher and his/her competence, confidence, and background (Dobrowen, 2020; Georgii-Hemming \& Westwall, 2010; Kaschub \& Smith, 2014). Music is also observed to be a threatened subject and area of practical and specialized knowledge area in teacher education, suppressed by less economically demanding arts subjects (Lindgren \& Ericsson, 2011; Nielsen, 2010). So far, little research has been conducted on the institution's websites and their role in gearing knowledge development in the specific directions in this field. This chapter is a contribution in that regard.

Websites are a main way of recruiting new students and of reflecting and constructing institutional visions, values, achievements, and learning opportunities for the public and for the internal audience. Studies of the websites of educational institutions have been conducted within several fields (Callahan, 2005; Campbell-Price, 2017; Leathwood \& Read, 2009; Zhang \& O'Halloran, 2013). Studies of university prospectuses suggest an increased shift from how universities earlier communicated their identity as academic communities of scholars and learners toward increased marketization and the use of corporate branding language (Askehave, 2007; Fairclough, 1993; Hoang \& Rojas-Lizana, 2015; Lažetić, 2019; Saichaie, 2011). Differences in university websites have also been identified as the consequences of national and institutional cultures (Callahan, 2005). Our approach to the examination of music/teacher education websites focuses on the negotiations of power/knowledge relations and the steering techniques that these include. Following Foucault's thinking on "authorship", we consider the authors of the websites as discursive entities who are "speaking" on behalf of the dominating discourses in each institution (Bayne, 2006; Foucault, 1977).

The background for this chapter is the research network MiU (Musikkpedagogikk i utvikling/Music Pedagogy in Development), established in 2018 through a collaboration among the four institutions that this chapter focuses on. Today, the MiU network consists of four institutions, five departments, and around 6o researchers employed at institutions that (intentionally or unintentionally) educate music teachers for schools, kindergartens, 
societies, communities, and higher education (Angelo, 2020, F1). These institutions and departments are built on different and even contradictory traditions but have in common that they qualify music teachers/musicians that also teach many of the same music teacher positions in the merged fields of practice. Discussions among researchers at the various seminars and workshops offered by the MiU network from 2018 to 2020 have led to several questions about what courses the different institutions offered, the titles of those courses and education programs, employees' titles, and the main aims for each education program. Institutionalized habits and norms were identified and questioned. For example, discussions arose about the variety of terms used for subjects, disciplines, professional titles, and practices - even though the content was more or less the same; also, the titles of professional positions and subjects were similar but reflected dissimilar content and practices. Those discussions and observations led us to the idea of thematizing the institutionalized differences and addressing the following research question: How is music/teacher education represented and conducted through the websites of four different institutions? The slash sign in "music/teacher education" is employed to mark that not all of these institutions have music teacher education as their primary target. For example, two of the institutions are first and foremost teacher educations, with explicit mandates to educate teachers for kindergartens or school, in diverse kinds of subjects and knowledge areas. Another institution in the study is primarily oriented toward educating musicians and musicologists, with pedagogical education as only one of several choices for the students. Still, all these institutions educate teachers, and who are qualified to teach music, or educate musicians/musicologists, and who are also qualified to teach - in schools, kindergartens and a merged practice field. An intention of the current study is not to identify any "right" or "wrong" music teacher education but to scrutinize the diverse representations of music pedagogical qualification that are expressed on the four chosen institutions' websites. We mirror them in each other and suggest correctives and discussions that might provide reflexive and conscious approaches toward qualifying music/teachers in the twenty-first century. Before we present the research design and the four cases and discuss our findings, we first outline our theoretical premises. 


\section{Theoretical Premises}

Theoretically, this chapter uses a discourse-oriented approach, where the term "discourse" is drawn from social sciences and cultural studies. Leaning first and foremost on Foucault's theories, discourse is employed as a concept connected with power and conducting for institutionalized ways of reasoning and acting. More specifically, the theoretical premises for this chapter are built on Foucault's (1998/1980) thoughts on power/knowledge and forms of steering and steering technologies, developed in his later writings and progressing from his earlier works on unfolding how historicspecific processes led to certain perceptions, articulations, and procedures in specific fields of knowledge (e.g., Foucault, 1966/1989, 1988, 1995/1975, 2003/1963). In particular, the chapter builds on the term "governmentality", which concerns the nature of power and the steering techniques that power operates in modern society (Dean, 2006; Foucault, 1991; Rose, 1996). Even though the term "power" rarely appears in study plans and strategy documents, this approach enables us to consider how power operates in the official representations of these education programs. Foucault sees power as productive rather than repressive and as mediated through all participants in a community rather than as a force directed from the top of the hierarchy. In fields of power/knowledge, for example, in the field of music pedagogy, certain perceptions, articulations, and terms are at stake. Related to this chapter, for example, are the ways to posit music as a subject, how music teacher qualifications are earned, and what they consist of, as well as ways to consider individuals as students, educators, and student applicants in relation to the education programs. In an analysis of governmentality, one main aim is to unfold how knowledge and power connect in specific ways and to determine which steering rationalities are included (Dean, 2006, p. 15). Through, for example, disciplinary power, pastoral power or biopolitical power, or through steering rationality as liberalism and risk conduct, individuals and groups can be seen to incorporate self-conduct and selfmonitoring to integrate well into a given power/knowledge community, or to "identitate" (Schei, 2007) specific self-understandings. "Discipline", in Foucauldian terms, is a mechanism of power that regulates the behaviors of individuals in a social society, while "pastoral" power encompasses these mechanisms toward some kind of "salvation" (Christianity), and 
"biopolitical" power also concerns an individual's biological and social body, including illness, health, life, and death. Thus, the institutions that serve as Cases 1-4 in the current study can be seen to fuel power through their website portrayals of individuals, learning activities, and knowledge development and to posit certain visions, ideals, and expertise as normal and rewarding.

According to Foucault, education is one of the strongest mechanisms in society because of its "claims for truth". Given that, not only is knowledge power but the paths toward knowledge are also paved with power. With governmentality as our theoretical lens, we aim to examine how power displays in subtle mechanisms that merge outer, direct, and visible steering with inner steering, such as self-discipline, ownership, and autonomy (Dean, 2006). The individual's participation in any power/knowledge community is authorized through incorporating specific perceptions, aims, and ways of using language; then, power operates to facilitate and stimulate certain actions and ways of thinking. In Rose's (1996) theories about governmentality and advanced liberal conduct, power operates with reference to the individuals as "free subjects" with the capability, responsibility, and agency to make wise choices on their own. Molding and regulating individuals and groups through representations of music/ teacher education can thus be viewed as ways of orchestrating the communities toward specific positionings and actions.

\section{Methodology}

In this methodological part of the chapter, we describe our data material, our analytical approach and ethical considerations, and the four music/ teacher education institutions which this study concerns (Cases 1-4).

The data material consists of screenshots (June 2020) of the official websites, including hyperlinks to course descriptions and descriptions of mission and vision, and subgroups and employees at the institutions investigated: (Case 1) Norwegian University of Science and Technology (NTNU), Department of Music; (Case 2) Queen Maud University College (DMMH); (Case 3) Nord University; and (Case 4) NTNU, Department of Teacher Education. All of these web pages are stored as PDFs using the 
Fireshot software and can be found in the OSF repository. ${ }^{1}$ The web pages are arranged by institution and number and will be referred to in the text as, for example, "C1, F1"-meaning: Case 1, Fireshot 1. Some websites exist only in Norwegian, so the translation to English used in the analysis section is done by the authors. Geographically, these four institutions are close ( $<80 \mathrm{~km}$; all located in the mid-Norwegian county Trøndelag), but the traditions and profiles of these institutions are different. Together, they qualify music teachers for kindergartens, schools, music and art schools, and universities. They all offer music/teacher education at the $\mathrm{BA}, \mathrm{MA}$, and $\mathrm{PhD}$ levels (alone or in collaboration with others) through the study programs of music performance, music technology, and musicology (along with one-year practical pedagogical education), vocational music teacher education, early childhood teacher education, general music teacher education for compulsory school, and specialized music teacher education.

The analytical work with this material follows a path framed by Jackson and Mazzei (2012) as a theory-driven approach to qualitative research. From this, the analytical process is more focused on identifications of steering techniques and knowledge/power relations based on a Foucauldian reading and less focused on following specific analytical steps. This theoretical approach also follows a considerable path of discourse theoretical studies within Nordic research in music education from 2000 onwards (Angelo et al., 2019; Jordhus-Lier, 2018; Krüger 2000; Lindgren \& Ericsson, 2011; Nerland, 2003; Nielsen \& Karlsen, 2020; Rolle et al., 2017). In this chapter, the term "discourse" is drawn from the field of social sciences and cultural studies and labels the whole set of terms, issues, and formulations embedded in a given cultural field. Steaming from Foucault's theories and development of the term discourse (from 1960), we employ discourse as a social theoretical term connected to power and reflecting on how power in society materializes in institutionalized ways of reasoning and acting. From this approach, researchers might identify certain discourses as, for example, dominating (commonly accepted ways to view and speak about certain matters), hegemonic (supreme,

1 https://osf.io/zdp7u/. Choose + on the option "data", and the PDFs turn up. 
interconnected with an ideology that justifies a society's acceptance of truths and normality), or antagonistic (opposing the given truths and normality, struggling among themselves to gain hegemonic positions). In the huge variations of how discourse-oriented research is connected, Angermüller (2015) suggests distinguishing between discourse-analytical paths, which follow exact methodological procedures, and discourse theoretical paths, which read the data from theoretical views without following particular steps and procedures. The current study follows the discourse theoretical path.

The ethical considerations in the present study concern the ways that we present our institutions and colleagues and how we engage in the analytical process concerning "our own" institutions' websites. Website/document studies have advantages regarding openness, availability, stability (in PDF), lack of obtrusiveness, and reactivity (Bowen, 2009). Still, the analysis and interpretations of these websites can lead to different connections, patterns, and conclusions. Even though an insider perspective can be beneficial to pinpoint and more deeply explain the historical development and effects of identified steering mechanisms, we have thoroughly engaged in reading each other's websites and questioned and rechecked in-progress analyses. The analysis has been conducted as a "bottom-up" approach, beginning with the body of website information. Ongoing discussions in our institutions - that are not represented on these websites - on the potential effects and causes have not been included in the analysis. With a social constructive approach, our aim is still not to present any one and only "truth", but to provide transparent and respectful interpretations and discussions with transient references to specific websites (as PDF files in the OSF repository) and previous research. The study is conducted in line with the Norwegian Guidelines for Research Ethics in the Social Sciences, Humanities, Law and Theology (NESH, 2016) and the guidelines and requirements from the Norwegian Data Protection Services (NSD). Internet research is thematized in both these guidelines, but still, there exist several gray zones. Direct consultation with the NSD gave us clear directions in storing and treating the websites from research ethical perspectives. One main consequence of these consultations is that all individual names and photographs on the websites are blurred in the OSF repository. 
The specific questions that frame our analyses are the following: (1) What dominating discourses mark the representation of music/ teacher education on the institutions' websites? (2) How are teachers and students positioned within the area of music education on these websites? (3) Which steering techniques can be identified to conduct educators and students through these representations? Before we discuss the findings, we briefly present our four institutions.

\section{The Four Cases}

\section{Case I. NTNU, Department of Music (IMU)}

The Department of Music (IMU) has 450 students and 100 employees. IMU has developed over the past 40 years from a teacher training college (later: NTNU, Department of Musicology) and an independent conservatory, being firmly anchored in a teaching program, to a professional education program integrated with NTNU that also meets the academic conceptions of knowledge, practices, and qualifications. Upon integration, the department's only pedagogical position disappeared because ILU (Case 4) took over responsibility for pedagogy.

IMU offers studies within four programs: music performance studies (including practical pedagogical education), musicology, music technology, and dance studies ( $\mathrm{C} 1, \mathrm{~F} 1)$. These programs all define their social mission by giving descriptions of job opportunities after study completion $\left(\mathrm{C}_{1}, \mathrm{~F}_{5}\right)$. The term "music pedagogue" does not appear among these social missions although the contents have significant pedagogical elements related to the job market and aim to qualify students for music teacher positions in compulsory schools and music schools. Music pedagogy is not mentioned in the titles of courses, with the exception of Instrumental Didactics, ${ }^{2}$ which is an add-on course that performance students can choose. IMU has no MA program in music education, but several of the

2 The term "didactic" as used in Scandinavian education context relies to the German term "Didaktik", which has a very different meaning than the English term "didactics" and can be explained as the science of teaching. Please see the introduction chapter in this book for a more thorough elaboration. 
MA theses in musicology ( $\mathrm{C} 1, \mathrm{~F} 11)$ and a few of the MA theses in music performance (artistic/scientific interpretation) are characterized by their pedagogical focus.

Even if the department staff participate in artistic and creative activities in national and international contexts, their titles only reflect their level in the academic hierarchy, such as professor, senior researcher, or assistant professor $\left(\mathrm{C}_{1}, \mathrm{~F}_{2}\right)$. There is one exception: there is an associate professor of music didactics (C1, F8) (author 4).

\section{Case II. Queen Maud University College (DMMH)}

Queen Maud University College (DMMH) is a private college with the social mandate to educate early childhood education teachers; there are approximately 1,400 students and 150 employees. In 2013, "Preschool Teacher" was renamed "Early Childhood Teacher Education". This marked a shift in the view of children as "becomings" to children as "beings". Today's framework of Norwegian kindergarten (Kunnskapsdepartementet, 2018, pp. 11-21) emphasizes the kindergarten as a cultural arena and one for children's participation and democracy, including children's play, wonder, and exploring. However, at the same time, several significant alterations appeared in early childhood teacher education. One was that the aspects of art and children's culture were diminished in the field of education, replaced with more focus on learning (Kunnskapsdepartementet, 2012). In all course plans pursued by the new framework, clear requirements are set for measurable learning outcomes. Another significant change was that education became centered around interdisciplinary subjects instead of specific disciplines and subjects, and general pedagogy was included among the interdisciplinary subjects. ${ }^{3}$ The reason for this was expressed in the curriculum framework: to target the education toward the teaching profession (Kunnskapsdepartementet, 2018, 2012). This led to that development that even though the title of the educational program and the profession turned away from the term "school", schooling, learning, and pedagogy were emphasized more. 
DMMH offers a BA (18o credit points [cp]) through four different programs with their own profiles and also four MA programs $(120 \mathrm{cp})$ in the following areas: (1) a general program of early childhood teacher education; (2) a program focusing on music, drama, and the visual arts; (3) a program focusing on nature and the outdoor environment; and (4) a program focusing on multiculturalism in early childhood teacher education (ECTE) $\left(\mathrm{C}_{2}, \mathrm{~F} 1\right)$. One of the master's programs includes the module Children's Culture and Art Pedagogy. Music is not a separate subject in the general model for ECTE but is included as one of several subjects in the module Art, Culture, and Creativity (ACC), which positions arts subjects and artistic activity as one of several paths in ECTE. This module is mandatory for all four BA programs but is differently emphasized depending on the BA program. All education programs target early childhood teachers as independent of the educator's subject-specific background.

The music department at DMMH holds six academic positions ( $\left.\mathrm{C}_{2}, \mathrm{~F}_{2}\right)$. Five of these (one associate professor and four assistant professors) all have "music" included in their professional work title. The one top-level position in this department, the professor (docent) (author 3), gained the professional title of music pedagogy by applying advancement. All employees in the music department have their master's degree from NTNU, Institute of Music (Case 1) (C1, F11). All employees therefore applied for their jobs at DMMH expecting to adapt the music content for the ECTE students and, through them, for the kindergartens (Jobbnorge, 2014, 2018).

\section{Case III. Nord University, Faculty of Education and Arts, Campus Levanger ${ }^{4}$ (NORD)}

Within Nord University, all artistic subjects are located within the Faculty of Education and Arts ( $\left.\mathrm{C}_{3}, \mathrm{~F} 1\right)$. The faculty has approximately 3,500 students and includes a division for Arts and Culture that offers studies in music, drama and in arts and crafts. The division's music department

4 Until recently, Levanger was an independent university (HiNT) and was merged with other universities to form Nord University in 2016. However, the structure of music teacher education continued, so even today, there is still an independent music teacher education, which can be examined as an individual case in the present study. (Within Nord University, however, the subject of music is also part of other teacher education programs on the Nesna and Bodø campuses.) 
at Campus Levanger has seven full and five associate professors and nine lecturers and assistant professors $\left(\mathrm{C}_{3}, \mathrm{~F}_{3} \mathrm{a}, \mathrm{b}\right)$. The music department has no individual website, and the university's website only provides a subpage for the research group Music-Related Learning Processes, which comprises 10 members of the music department $\left(\mathrm{C}_{3}, \mathrm{~F}_{2}\right)$. The music department offers three study programs: (1) music teacher training (BA, $18 \mathrm{o} \mathrm{cp}$ ); (2) music teacher in music schools (kulturskole) (BA, 18o cp); and (3) an MA in music and ensemble direction (120 cp). Furthermore, there is the possibility of undertaking a doctorate in the field of music education (PhD program, Study of Professional Praxis).

None of Nord's course titles mentions musikkpedagogikk (music pedagogy) or similar terms (e.g., musikkdidaktikk/music didactics). However, musikkpedagogikk (music pedagogy) is part of the content of several bachelor's courses. First and foremost, it is an explicit and main element of the "teaching profession" modules ( $45 \mathrm{cp}$ in total; these modules combine various educational contents and subjects). Outside these modules, when musikkpedagogikk (music pedagogy) is mentioned, there is often a strong focus on methodological aspects (e.g., warm-up techniques for choir singers) or a more implicit understanding (e.g., through mentioning a target group, like primary school children, for whom a piece of music should be composed) $\left(\mathrm{C}_{3}, \mathrm{~F} 7\right)$. In line with these observations, the term "pedagogy" is mostly used without the prefix "music," mainly when general pedagogical content is addressed (allmenpedagogikk/general educational science). When the term "music" is combined with educational content, the term "didactics" is mostly used (i.e., musikkdidaktikk). Within the curriculum of the MA program, the term musikkpedagogikk (music pedagogy or similar terms) is not used at all. However, there is the possibility of realizing projects and artistic work in pedagogical contexts (kindergarten, primary school, etc.). Also, an MA thesis can have a pedagogical focus $\left(\mathrm{C}_{3}, \mathrm{~F} 8\right)$.

At Nord University, the employee register shows only the positions (professors, lecturers, etc.) at the register's top level ( $\left.\mathrm{C}_{3}, \mathrm{~F}_{3} \mathrm{a}, \mathrm{b}\right)$. Music as a subject is not explicitly mentioned as part of the descriptions but is assigned to a person within a subcategory ("employee's skills", i.e., the content indicated by "music" is attributed as a "skill" to any person 
working with music in any way). Scientific/artistic disciplines/domains (e.g., music education, musicology, violin, conducting, etc.) are not mentioned. Within the Department of Music, there are two employees with a $\mathrm{PhD}$ in (music) education (and four doctoral students working on a $\mathrm{PhD}$ in music education). The other employees (i.e., the vast majority) have an artistic professional background and subsequently teach mainly artistic courses $\left(\mathrm{C}_{3}, \mathrm{~F}_{3} \mathrm{a}, \mathrm{b}\right)$. $^{5}$

\section{Case IV. NTNU, Department of Teacher Education (ILU)}

The Department of Teacher Education (ILU) at NTNU is presented on the website as Norway's largest academic environment within teacher education and educational research, with around 360 employees and 4,00o students $\left(\mathrm{C}_{4}, \mathrm{~F}_{4}\right)$. The overall focus is to educate general and subject-specific teachers in all school subjects for grades 1-13, as well as to educate school leaders. All course descriptions at ILU are clearly targeted at the profession of teaching. ILU offers education at the BA, MA, and PhD levels and a one-year add-on teacher program. The artistic and pedagogical development work and research at ILU is also geared toward schools, classrooms, and workplaces. This focus on the teaching profession strongly influences all sections at ILU, including the Arts, Physical Education, and Sports section, which comprises 38 professional positions, out of which 13 are within the subsection Music, Dance, and Drama, and seven positions are in music or music education $\left(\mathrm{C}_{4}, \mathrm{~F}_{3}\right)$.

The music department does not have its own website: it is part of the interwoven Arts, Physical Education, and Sports section and focuses on bodily, sensory, and aesthetic approaches to teaching and learning $\left(\mathrm{C}_{4}\right.$, F2). Within the 10 bullet points presenting "research in, about or through the arts and artistic development", the word "music" is displayed in one, while the other nine more generally describe research on teaching pedagogies, arts education, aesthetic learning, art in public spaces, and so on.

5 Timeedit, which is open to search for the individual staff's teaching tasks: https://cloud.timeedit. net/nord/web/open/ri161XQQ7woZuoQv5605YgZ6ynY.html 
Several of the course descriptions within music reflect that music is part of the interdisciplinary subject of "arts education" (e.g., the two-year MA program in arts education). Following this, subject-specific words such as "music", "musician", and "musical" are replaced with more general and, hence, not discipline-specific terms such as "the arts", "artist", and "artistic". The lexical term "music pedagogy" exists in one study plan at ILU as a research and development (R\&D) subject in the five-year teacher education for the compulsory school (MGLU) with MA in music.

The employee register at ILU shows both position and subject $\left(\mathrm{C}_{4}, \mathrm{~F}_{3}\right)$. The music group has one "professor in music education", one "assistant professor in music didactics", four "assistant professors in music", and four "associate professors in music". Two of these associate professors have a $\mathrm{PhD}$ in music education $\left(\mathrm{C}_{4}, \mathrm{~F}_{3}\right)$. The whole context of ILU's website $\left(\mathrm{C}_{4}, \mathrm{~F}_{1}\right)$ reflects that all employees are, first and foremost, teacher educators, even though that is not specified in the employees' professional titles. By clicking those employed in music and on their publication lists, it can be seen that two of the associate professors have music performance as a central R\&D area, while the other five have either scholarly music education research or a mix of music performance/music education research as their core R\&D work.

\section{Dominating Discourses that Form the Representation}

Across the presented institutions, we identified four discourses that operate power/knowledge relations in the representations of music/teacher education through embedded steering techniques. The first three include an antagonistic division between two confronting chains of equivalence, which both through present and absent elements demand hegemony: (i) two antagonistic profession discourses, (ii) two antagonistic discourses on the subject of music (iii) two antagonistic discourses on R\&D, and (iv) a discourse of marketization. The following text elaborates on the identification of these discourses, examines how they seem constructed and how power operates through them in positioning individuals, groups, aims and articulations of knowledge. In the conclusionary remarks, we scrutinize the 
authorities through which these discourses are mediated and critically outline some effects that these might have on future music/teacher educations.

\section{Profession Discourses: Music or Pedagogy?}

The profession discourse is marked by two antagonistic discourses: one fore fronting music and musicians/artists and the other foregrounding pedagogy and pedagogues/teachers. Cases 1-4 position quite differently on an axis between these representations, with Case 1 (IMU) being the most marked on the first (music); Cases 2 (DMMH) and (partly) 4 (ILU) the most marked on the latter (pedagogy, teacher education); and Case 3 (Nord) somewhere in the middle.

\section{Music-Oriented Representation}

On their opening web page and in the descriptions of the institution, courses, groups, and individuals, IMU (Case 1) claims to educate excellent and groundbreaking musicians. For example, a video portrayal of one of IMU's performance educators presents herself as a person who has "always played music" and posits music as being "about performing and communication" $\left(\mathrm{C}_{1}, \mathrm{~F}_{3}\right)$. Governance can be seen as operating power by "recognizing individuals" capacities for freedom and agency and directing this energy in specific ways" (Rose, 1996). IMU's portrayals can be seen as a means to identify the external and internal aims and background of individuals and gear their efforts toward integrating themselves well into IMU's community and the institution's discursive terms. This means, for example, spending much time practicing an instrument, aiming for personal expressions, and describing their knowledge development with words from the music performing world. Authority is then claimed for perceptions of music education directed at music performance. To operate self-understandings as musicians and performers displays as a prevailing condition in this education program, conducting self-discipline and effort to certain actions.

Music teacher education and music pedagogy are never mentioned in any of IMU's 165 course titles (except in the $30 \mathrm{cp}$ course Instrumentaldidaktikk). Neither is it apparent that all employees here spend $40-60 \%$ 
of their time teaching. The words musikkpedagogikk and "music teacher education" are absent from all course descriptions. Still, IMU's website calls attention to how at least $80 \%$ of the students will become employed as music teachers $\left(\mathrm{C}_{1}, \mathrm{~F}_{4}\right)$, and that educating music teachers is a crucial part of this institutions social mandate. For example, the vision and mission page about the music performance program states that "music performance education at NTNU Department of Music shall educate highly qualified performing musicians and music teachers" ( $\mathrm{C} 1, \mathrm{~F} 6)$, and the musicology program is described as follows: "Educating adjuncts and lecturers for the educational system was and is the most clearly defined social mission for the educational program of musicology" (C1, F7). Several of the courses at IMU are directed at leading others in musical activities (ensemble leadership, accompaniment, cantor practice, laptop instruction, performance) $(\mathrm{C} 1, \mathrm{~F} 1)$. Through transient omission of the employees' teaching practice and words of pedagogy/didactic/teaching and learning in course titles, the websites might be seen to route the IMU environment towards emphasizing musical artistry, creative and performing courses, and research. Viewed in totality, there is a discrepancy between the formalized social message about job opportunities, on the one hand, and the factual contents of course plans and teacher status, on the other hand. The responsibility for pedagogical education and introduction into educational research seems clearly ascribed to ILU $\left(\mathrm{C}_{1}, \mathrm{~F} 1\right)$.

IMU's discursive praxis suggests that music education itself qualifies music teachers, without referring to either pedagogy or teacher education. This claims the authority to view and articulate musical knowledge as implicitly also referring to teaching expertise. In a governmentality analysis, power does not originate from a centrum but is a productive force that circulates among individuals and groups in all parts of a hierarchy. Through the websites, course plans, and presentations, power is exercised through directing individuals and groups to follow a music performance path and considering this to implicitly contain music teaching expertise.

\section{Teacher/Pedagogy-Oriented Representation}

The two institutions clearly positioned on the teacher/pedagogy part of the music pedagogy axis are DMMH (Case 2) and ILU (Case 4). 
The websites of both institutions posit music as one of several subjects that play a subordinate role in qualifying teachers. For example, the following statement appears on ILU's website: "We educate teachers within a wide range of school and vocational subjects for grades 1 through $13 . .$. Our practice- and profession-oriented programs provide a solid foundation for future careers and life-long learning" $\left(\mathrm{C}_{4}, \mathrm{~F}_{5}\right)$. Music is just one of several subjects and is subordinated to the professional subject of pedagogy for earning a teaching qualification. Arts subjects on DMMH's website are positioned more as decorations in the form of photos of students doing music and art than as autonomous areas of knowledge and expertise. The primary subject at DMMH seems to be early childhood pedagogy. The term "music" is expressed and communicated as an expert field only in announcements of new positions (e.g., Jobbnorge, 2014, 2018). It is taken for granted that early childhood pedagogy is a lens for teaching and understanding the qualities of music in education when explaining the child's holistic development and cultural expression. Additionally, all music lecturers at DMMH have received their MA in music education from IMU $(\mathrm{C} 1, \mathrm{~F} 11)$, the institution that most clearly downplays pedagogy and teacher education. Following this, music lecturers at DMMH meet institutional expectations to "use" music as a tool for learning outcomes, such as social competence, language and communication development, cultural education, and aesthetic experience, without any educational background represented to cover such topics.

In both institutions (Cases 2 and 4), power is encompassed to view the subject of music as one of several subordinated fields of knowledge that future teachers gain from. In the same way as in the music-oriented representation of music pedagogy, these representations incorporate a claim for knowledge with embedded power relations, but the other way around. Here, pedagogy and teacher orientation mark the territory and work toward self-technologies that lead toward becoming a teacher andthrough this-mean something for the child, the school, and society. These self-technologies are operated into the positioning of students and educators.

A common position that unites the communities at ILU and DMMH is their way of representing future teachers as responsible and autonomous 
individuals with ambitions to be saviors. For example, ILU's website states, "As a teacher at a primary school, you are more than a person with a responsibility for the subject content. You are a key person in the child's life" $\left(\mathrm{C}_{4}, \mathrm{~F}_{5}\right)$. This quote positions the student and future teacher as an important person with a responsibility for understanding and taking care of the new generation. "A key person" in a child's life bears a main responsibility and authority to govern society and humans in the future. ILU's website can be seen as operating a pastoral form of power through portraying teachers as someone who can both lead children toward important knowledge and care for children's growth as members of a society. This power is even more clearly observed on DMMH's website, which opens with the following: "Are you adult enough to work with children? Choose early childhood teacher education at DMMH. Then you will obtain the skills that you need for the new jobs that exist. Do what's best for children" $\left(\mathrm{C}_{2}, \mathrm{~F}_{3}\right)$. On DMMH's website, we identified an embedded encouragement to "save" the children and an included presupposition that this role needs to be qualified. In positing that children's welfare is at stake, this representation operates both pastoral and biopolitical forms of power, including both the bodies and minds of the new generation. These self-steering mechanisms are further emphasized through a range of testimonials from teachers and students on DMMH's website, which all forefront DMMH as a provider of education where both students and teachers make a difference. Through DMMH's education program, the students gain professional identity and pride - to become child caretakers, or maybe even "child saviors" and thereby "societal saviors", even though what the children need to be saved from is never articulated.

So far, we have identified representations of music/teacher education as, more or less, without music and, more or less, without pedagogy. Nord University's position is somewhere in between, with an equal emphasis on music and pedagogy, operating power mechanisms and presenting claims for knowledge that include both positions. On Nord University's website, pedagogy is often the context referred to without determining precisely the relationship of a course's content to this context, what exactly pedagogical thinking means, or what the content means for the pedagogical thinking. A musicology course description 
illustrates this: "The student can apply knowledge of music history in his didactical practice" ( $\left.\mathrm{C}_{3}, \mathrm{~F}_{4}\right)$.

When turning to the professional titles of the employees at the four institutions, only ILU and DMMH label their employees according to both title and subject, for example, as "associate professor of music". IMU and Nord, on the other hand, only offer the employees an academic title (professor, associate professor, etc.) without any reference to the subject. This posits the academic hierarchy as the dominating subject and operates power that claims climbing the academic career ladder as superior to subject-specific expertise. The academization discourse will be elaborated on later in this chapter, but this labeling of the professional community also concerns targeting professions. Through a praxis that molds academic aspirations as crucial, the academic positioning of music teacher educators operates power contributing to a public presentation of music pedagogy. Both students and educators are provided with tools and opportunities through their education to act on this, which entails effort to influence individuals and groups to follow desired directions.

In sum, we find two antagonistic discourses that operate power through recognizing and targeting the capacities and agencies of individuals and groups to posit music/teacher education as falling primarily within either music or pedagogy. Music teachers (students and educators at these institutions) are offered roles as "child saviors", "music experts", "performers", and "community-builders" and are provided with the language, tools, and choices needed to fuel their professional development toward this. These two discourses exclude each other and make it challenging to involve understandings that merge them. A main topic in the field of music education research is which ideals govern; those of music or those of the individual and the society (Bowman, 2007; Ericsson \& Lindgren, 2011; Georgii-Hemming \& Westwall, 2010; Sætre, 2018). While general teacher educations emphasize social skills and personal growth, fronting music as a means toward this, specialized music educations emphasize individual music skills and artistic expression, being less concerned with classroom management and music activities for inequal groups (Sæetre, 2018). Critical concerns here include observations that legitimacy for 
arts education in teacher education is constructed through positioning students, teachers, and future pupils as in need of therapy. A lack of specialized knowledge and expertise in music is even seen as a quality mark for teacher competence and a pedagogical tool, in positioning the students and the teachers with equal, unskilled premises (Lindgren \& Ericsson, 2011). Also, specialized music teachers rarely include collective music activities such as singing and dance in their music teaching in the compulsory school, instead focusing on individual skills, listening and composing (Sætre, 2018). Because of a continuously merging practice field and hybrid tasks for music teachers - future music teacher education programs seem to need grounding in several approaches that can provide for a multitude of identity formations, role understandings, and epistemological standpoints. A challenge for future music teacher educations then seems to be to critically reflect on the diverse perspectives and steering techniques that these include and to provide a meeting place to articulate and critically reflect on the differences where students and educators develop tools to identify, discuss, and even change the hegemony and antagonistic representations of music teacher professionality as either concerning music or concerning humans.

\section{Interdisciplinarity: Music and "the Arts" - Two Sides of the Same Coin?}

The websites represent the subject of music in two different ways: (i.) as its own autonomous field of expertise (IMU and Nord) and (ii.) as part of an interdisciplinary field of "arts education" (DMMH and ILU). Within the more or less "pure" music-specific representations, the area, groups, and individuals are posited as individuals (IMU) or participants in a community, together with the educators, co-students, and related communities (Nord). Within its interdisciplinary representation, music is presented as an area with desires for "aesthetical approaches to learning" and as an area where subjects such as music, visual arts and drama, and theater and dance are considered several sides of the same coin. The tendency to merge music with other arts subjects is also observed in Danish and Swedish music/teacher educational programs (Holgersen \& 
Holst, 2020; Lindgren \& Ericsson, 2011; Nielsen, 2010). As a result of that music has disappeared as a compulsory subject in general teacher educations in several countries (2003 in Norway, in the 1980s in Denmark; Holgersen \& Holst, 2020, p. 9), general teachers in schools have not necessarily received any music teaching since they left compulsory school as teenagers, the number of music educators within general teacher educations is falling, and (the cost-demanding) subject of music is generally marginalized both in teacher educations and in schools. Although there are similarities between music and arts subjects such as dance, drama, and arts and crafts, there are also considerable differences. For example, regarding the emphasis on handicraft and overarching intention. Lindgren and Ericson (2011) find that although drama in Swedish teacher education aims to improve the students' general sense of security as a teacher, music aims for teacher security specific related to situations involving singing and playing based on concrete technical skills in music.

The techniques of conduct are embedded in several ways in the interdisciplinary representations of music at the four institutions' websites. For example, the music group at ILU is part of an interdisciplinary section: "The Arts, Physical Education, and Sports section focuses on bodily, sensory and aesthetic approaches to teaching and learning. The section works with both practice-led and theory-driven research and artistic development, and inclusive and critical perspectives on teaching pedagogies" ( $\left.\mathrm{C}_{4}, \mathrm{~F}_{2}\right)$. In this quote, both students and teachers in music education are targeted to self-monitor and self-regulate their behavior and interest in bodily, sensory, and aesthetic approaches. Other possible approaches, such as subject-specific knowledge, technical skills, and familiarity with repertoire and performance, are left out. Further, this quote from ILU is followed by another phrase: "A goal is to promote ethically conscious relations, dialogues and collaborations across disciplines and boundaries, within the context of the teaching profession" $\left(\mathrm{C}_{4}, \mathrm{~F}_{2}\right)$. This can even be seen to suggest that other approaches might lead to unethical relations, dialogues, and collaboration. This is a powerful statement (operating disciplinary, pastoral, and biopolitical power), where the words "across disciplines and boundaries" clearly state the 
interdisciplinary aim. Subject-specific knowledge development could, from this perspective, be judged as contrasting with and contradicting the aim of ethical consciousness. The language and terms here work as an apparatus that conducts the notions of music in more or less the same way as, for example, dance, drama, and visual arts, suggesting that music can be unproblematically merged with or even replaced by one of the other subjects within "arts education".

Another example can be found with DMMH, where music is not a separate subject in the general model for ECTE but is included as one of several subjects in the module Art, Culture and Creativity (ACC): "The knowledge area [ACC] emphasizes aesthetic experiences, reflection, communication and expression through various sensory media ... the development of students' aesthetic awareness, practical skills and creative abilities, as well as insight into the art possibilities and intrinsic value and their role as mediating tools in other areas of knowledge" (C2, F4). Arts education is positioned in a utilitarian manner as "tools" for learning diverse subjects and ways.

These representations of the subject of music display how terms, procedures, and knowledge are at stake. The different representations of music function as a steering technique that operates through the whole institutions' thoughts of capacity, lives, and rewarding actions. Interdisciplinary and overdisciplinarily are seen as beneficial to counteract subject-specific introversion and narrow-mindedness and to elucidate and utilize music in broader educational contexts but at the same time can be a menace to concentrated absorption in music as its own specific art area with distinctive challenges for subject-specific know-how and insights (Nielsen, 2010, p. 15). Without these skills and crafts, the concept of quality in music and other arts subjects' faces being relativized in teacher education because a lack of skills might become regarded as a superior teacher competence to align the positions between the teacher and the students (Lindgren \& Ericsson, 2011). A challenge arising from the analyses is how music teacher education programs might qualify to reflect these perspectives up against each other, discuss what is gained and what is lost, and consider this in relation to the diverse contexts that future teaching musicians/ music-oriented teachers might meet. 


\section{Academization: Scientific Research or Artistic Development?}

Due to extensive merging in Norwegian higher education in the last 25 years, many conservatories and music/teacher education programs have changed their institutional status from colleges or college universities to full universities. With this academization process comes increased expectations for research, publications, academic career routing, and level-standardized education programs (Angelo et al., 2019). All cases in the current study employ the academic routes for $\mathrm{BA}, \mathrm{MA}$, and $\mathrm{PhD}$ degrees, and students are supposed to either write a BA or MA thesis or perform and be graded on their BA examination concert. While processes of academization are seen to possibly strengthen the legitimization of music education and music teacher education and increase critical reflections among students and teachers, they threaten time and courses for developing handicraft knowledge and technical skills in music education (Borg, 2007; Georgii-Hemming et al., 2013; Lindgren \& Ericsson, 2011; Varkøy et al., 2020).

In our study, this process of academization is displayed, among other things, through banners on the various websites promoting research (DMMH, Nord, ILU), or either just research or research combined with artistic development (IMU) (C1, F9; C2, F1; C3, F1; C4, F1). Under these banners, there are hyperlinks to a wide variation of research groups and projects. This will route internal as well as external readers toward a notion of $\mathrm{R} \& \mathrm{D}$ as something one is expected to do and is rewarded for. IMU states, “The Department of Music has approximately 80 researchers and performing artists, including tenured staff, emeriti and temporary or guest researchers". None of the research groups and research projects under this banner include any phrasing regarding music teacher education or music pedagogy/didactics. The subwebsite Artistic Research and Development is presented with the following introduction: "The department's professional staff contributes extensively to the artistic R\&D through its involvement in diverse activities such as musicians performing at concerts, recordings and media contributions locally, nationally and internationally-both as soloists, in a chamber music context, and as leaders of various types of ensembles and orchestras. Several of the 
department's employees are also active composers" (C1, F1o). This phrasing follows up on the professional targeting discussed before, which positions individuals and groups first and foremost as music artists, performers, and creators.

In Case 3, ILU's subsite for research states, "Our skilled teacher educators conduct R\&D work targeting schools, classrooms and workshops", steering the efforts of $\mathrm{R} \& \mathrm{D}$ toward schools and the general teaching profession $\left(\mathrm{C}_{4}, \mathrm{~F} 6\right)$. Case $2(\mathrm{DMMH})$ routes energies in $\mathrm{R} \& \mathrm{D}$ toward children, childhood, and kindergarten: "DMMH aims to produce relevant research and provide new knowledge of early childhood education and care to the society in general, as well as to our students and collaborating institutions at home and abroad" $\left(\mathrm{C}_{4}, \mathrm{~F}_{4}\right)$. Under the banners for research on both the ILU and DMMH websites, music teacher educational research is represented with a hyperlink to the earlier mentioned research group MiU. At Nord University, one research group articulates music teacher education as a main aim, operating power that directs groups and individuals to act on music pedagogical themes in their research and artistic development work. Some interesting additional information here is a concern at Nord University, ILU, and DMMH that artistic developmental work does not "count" for standard publication points in the same way that peer-reviewed publishing in academic journals does. At Nord, this has the consequence that employees who do not publish (enough) are "punished" with more time spent teaching; part of their research time is reduced, which is then "converted" into teaching time ( $\mathrm{C}_{3}$, F9). In this way, power works in the community to steer individuals toward publishing rather than toward music performance efforts. This is the case even though most of the educators here are recruited from and employed with a background in music performance $\left(\mathrm{C}_{3}, \mathrm{~F}_{3}\right)$.

The representations of $\mathrm{R} \& \mathrm{D}$ work on these four institutions' websites display a tension between (1) a scientific path and (2) artistic path. Interest, enthusiasm, and effort in research activity is expected from both educators and students and can result in (1) scientific publications as journal articles, academic books, or BA, MA, or PhD theses or in (2) concerts or other performative presentations at senior and $\mathrm{BA}, \mathrm{MA}$, or PhD levels. The Norwegian system for financing research in higher education rewards 
the scientific path, with funding from the state given to the researchers' home institution for each published article, book, theses, and so forth. A similar system for artistic presentations has been requested for decades but is still lacking. Music education research calls for clearer articulation and critical reflection but warns of transforming music into a pure "academic" subject and neglecting the development of specific knowledge and skills that pertain to music as an art form (e.g., Bowman, 2007; Georgii-Hemming et al., 2013; Kaschub \& Smith, 2014; Nielsen, 2010). Although scientific and artistic paths could benefit from informing and challenging each other, a main issue rising form the analyses above is that these discourses seem to disqualify and exclude one another. Considering the identified steering mechanisms regulating the individual and collective conduct toward R\&D, it seems unlikely that these expertise communities can communicate from a common ground. For example, methodology, verbal reflection, and positioning within previous research seem less emphasized in artistic paths for development and research, and dimensions of art seem less emphasized in pure scientific paths in music educational R\&D. Without communication and exchanging ways to work with $\mathrm{R} \& \mathrm{D}$, these paths might continue scientific and artistic approaches as oppositions, leading to narrow-mindedness and exclusion, instead of embracing diversity and inclusion.

\section{Marketization: Toward a Corporate Branding of Music/Teacher Education}

University promotions in the twenty-first century are found to have a growing tendency toward marketization, advertising, and student competition (Fairclough, 1993; Lažetić, 2019; Mautner, 2012). In our analysis, a market-oriented rationality for education is displayed on the websites of all four institutions. All websites are designed in a "streamlined" way, with more or less the same information under generally the same banners. This relieves student applicants of having to search for information and eases the administrative work for these studies, but it also works to suppress the possible characteristic features of each institution. A marketoriented rationality is also displayed through the advertising style of the 
presentations of all four institutions, with language adopted from the corporate world (e.g., excellence, strategy, input, output), not least in the personal and direct ways that students are addressed. For example, a student testimonial on DMMH's web page claims that DMMH's education programs "will change your life and make you see things differently" $(\mathrm{C} 2, \mathrm{~F} 1)$. Here, power operates with reference to the individual freedoms and capacities and (seemingly) leaves it to the individuals and groups to choose the suggested paths, take up the offered subject positions, and then self-monitor and self-conduct toward the given opinions, identities, and desirable knowledge. Each individual is expected to "perform a regulated form of freedom" (Rose, 1996) and to follow given paths.

The corporate style of addressing students and student applicants as responsible and active customers is a considerable pattern on Nord University's website: "As a music student in Levanger, you become part of a vibrant and active music community consisting of around 140 students. You will also have good access to the practice rooms and technical equipment. In addition, there is a separate, student-run club scene on campus: Røstad Scene. This is a good arena for students who want to practice music or who want to learn more about the technical aspects, such as sound and light" $\left(\mathrm{C}_{3}, \mathrm{~F}_{5}\right)$. This posits students as responsible, operative, and selfsufficient customers, with their own capacities to direct their education. The educators at Nord are positioned as conventional partners, facilitators, and coaches, even as co-students-who are available resources for each student to utilize. The hierarchy between students and teachers is minimized at Nord, for example, in a course description: "Emphasis is placed on student active learning through, for example, presentations, teaching, self-reflection, work in groups, role-play and multimodal learning forms. Participation and active collaboration between students is necessary" (C3, F6). Here, advanced liberal governing (Rose, 1996) can be identified, allowing the students to "learn from experience" and freely choose to participate in the music environment offered to them. Such freedom is a presupposition for power to be performed, according to Foucault (1991) and Rose (1996), in market-driven higher education governance structures.

On IMU's website, the same liberal form of governing is observed, but in another direction: "At the Department of Music, we educate the 
future professional musicians and music educators in jazz, classical music and church music. The bachelor's program in music performance gives you the opportunity to develop musical skills to a professional level, through targeted work on your main instrument, in the meetings with established musicians and through the development of a personal artistic expression and good communicative ability" ( $\left.\mathrm{C}_{1}, \mathrm{~F}_{3}\right)$. This quote exemplifies how students and student applicants at IMU are directly addressed through the pronouns "you" and "your". The terms "a professional level", "established musicians", and "personal artistic expression" positions the students as novices in an expert community. The teachers at IMU are profiled through photos, videos, and text as recognized musicians, while the phrasing "NTNU has trained some country's most famous performers in all genres" $\left(\mathrm{C}_{1}, \mathrm{~F}_{3}\right)$ distributes these positions as possible for novices to gain. In contrast to Nord's website, the teachers at IMU are positioned as experts, with exclusive capabilities that novices can also achieve-if and when they follow a foot-worn path and integrate themselves well into the disciplinary systems of an expert, performing music community. Incorporated in this is the expertise needed to teach music well.

Although music in compulsory school in Norway (in 2020) is one of 10 subjects in a common education with tasks to form wise and participating citizens of society, music is a massive sector in society with many informal educational routes free for the individual to choose. Educated music/ teachers meet a work market where many of these routes are merged and influence each other. The analysis above displays how the marketization of the higher education institutions positions the institutions as resources, free for the individual student to choose, as customers in a shopping mall. This marginalizes the institutions' mandate and responsibility to enhance the students and the field of music education with aspects that cannot be ordered and delivered based on individual requests (e.g., responsibility toward democracy, inclusion and diversity). Previous research has identified how music education is made a personal matter both in compulsory school (Georgii-Hemming \& Westwall, 2010), leaving the content and the aims for the subject up to the individual teacher and his/her day form, and in extra-curricular music and art school (Holmberg, 2010), leaving it up to the individual student to "order" what music education 
concerns. Through the present study, the higher educations in music and teaching might have abandoned any overarching ambitions beyond the student's individual choices. This raises the question about the music/ teacher educational programs' collective responsibility and reflections on any common content and target groups. Research concerning music education and music teachers calls for manifold, inclusion and attendance to both differences and quality (e.g. Bowman, 2007; Georgii-Hemming \& Westwall, 2010; Kaschub \& Smith, 2014), emphasizing higher education as a transforming place to take care of all this (Johansen, 2006; Kaschub \& Smith, 2014). From this, it seems crucial for the diversity of music/teacher educations to attend to the differences and articulate their mandates and visions beyond individual preferences and customized proposals. Faith in the individual is good, but higher education toward the hybrid work marked for music/teachers should perhaps have something common to add. The latter seems in that case essential to be articulated.

\section{Concluding Remarks}

Through the analyses, we have identified informal steering techniques that regulate the individual's and collective's prospects, self-understandings, values, and languaging of music/teacher's work and competence. These techniques operate disciplinary, pastoral, and biopolitical power in close persuading individuals, groups, and institutional communities. Our intention with these analyses has not been to detect "the best" music/ teacher education program, nor to rate the four institutions in any way. Instead, our intention has been to examine the representations and conduct of music/teacher educations on these websites, mirror them in each other, and articulate possible correctives and discussions to evolve future music/teacher education programs. In this last section of the chapter we first sum up our discussions and identified discourses (i.-iv.), and then pose some disturbing prospects that ignoration of these informal steering mechanisms might bring for future music/teacher education programs.

(i.) We have identified two antagonistic discourses on professionality: the first perceived and articulated from the basis of music (Cases 1 and 4) and the latter with a basis in pedagogy and the teaching profession (Cases 2, 3 , 
and 4). These findings coincide with previous music educational research, pointing to how music teacher education is targeted either toward music or toward humans as individuals and groups (e.g., Bowman, 2007; Ericsson \& Lindgren, 2011; Georgii-Hemming \& Westwall, 2010; Sætre, 2018, 2014). Our contribution is the identification of these antagonistic perspectives on public websites that pursue both the established communities and recruiting students. (ii.) Two opposite positions were identified regarding music as a subject. One involved music as its own, autonomous area of expertise and terms (Cases 1 and 4), and the other encircled music as one of several subjects within "the arts", with aesthetical learning and sensory and bodily experience as a common area of knowledge and terms (Cases 2 and 3). Music as a subject has been found to either reflect objects or activities (music/musicking, e.g., Elliot, 1995; Small, 1988) and in teacher educations to reflect an overdisciplinary area of knowledge, including subjects such as drama, theater, dance, and arts and craft (Lindgren \& Ericsson, 2011; Holgersen \& Holst, 2020; Nielsen, 2010). Worries have been expressed both about adopting narrow-minded and restrictive views on music and about depriving music-specific knowledge and skills through positioning music as part of mere broad and overdisciplinary knowledge areas. (iii.) $\mathrm{R} \& \mathrm{D}$ is emphasized as main activities and interest on all four websites. An underlying tension in this discourse is that although scientific research is displayed as self-evident and unproblematically provides funding, many employees are recruited from performance and musical backgrounds and teach first and foremost in practical music disciplines. Artistic research and artistic developmental projects are registered on the websites, but scientific research has proved most gainful in higher education systems. (iv.) All the examined websites operate a liberal form of conduct and position students and educators as free individuals with the capability and responsibility to form their own lives and agencies. The educations are presented in advertising and competing ways, realizing music/teacher-roles and competence as personal choices and obligations.

These analyses have led to the following question: Who - from what knowledge community, background, and agency - should lead the development of music teacher education programs in the future? Should this, 
for example, be people from "music", "pedagogy", "the arts", "research" or perhaps from an advertising agency? The discussions above suggest that fundamentally different values, terms, knowledge, and mandates might be staged in future music/teacher education programs, depending on whose and what communities' "naturalness" is mediated. We could, for example, see a future in which professors of "arts education" replace today's professors of "music education" and in where subjects in "music" are replaced with subjects in "the arts". We can also foresee a future in which teaching and pedagogical expertise is no longer part of higher music education programs. Higher music education can also be envisioned without any academic schooling, where writing and reflecting are replaced with performing and creating - or the opposite: in which academic research and top-level publishing becomes the most central activity in music education at all levels. Further, we can imagine how the increasing marketization of music teacher education allows anyone, without any specific music educational background, to perform as capable and responsible managers of future reforming and recreation, or to phrase it in advertising terms, "renewing" of music teacher education programs.

Here, it seems necessary to advance awareness within music/teacher educations about how informal regulations and mechanisms authorize specific power/knowledge connections, for example, how self-discipline, prospects, and efforts are routed toward individual practicing, social, or therapeutic endeavors, intervening with other subjects or writing articles, or how articulations and framings in advertisements for new positions, funding, and projects gear recruitment and knowledge development. This concerns what and whose knowledge, views on music, humans, societies, learning and teaching, and values and visions are governed in music/teacher education programs and whose and what that are left out. Such awareness is challenging, if not impossible, to gain from "inside" this various field because antagonistic mechanisms cultivate exclusion and hinder meta-questions. Also, discussing identified regulations is a challenging endeavor because the terms and names in this field are loaded and infiltered parts of the mechanisms. It is undoubtedly difficult to speak without words, and it might be so that the various fields 
of music education lack words. A more nuanced terminology might be required to refine and deepen the reflections about music, learning, and teaching in accordance with the diverse approaches that all might be valid to meet different contexts, people, and music(s). Teaching musician/ music-oriented teachers is one such attempt (Bowman, 2007; Kaschub \& Smith, 2014), and music/musicking is another (Small, 1989); in this chapter, music/teacher educations are a third. This path of slash terms can illustrate an area of terms and approaches to be developed and a common meta-level where aspects of agency and steering mentality are identified, thematized, and critically discussed. To do this, the communities need to communicate, and exactly this seems to be a needed part of the agenda.

\section{References}

Aglen, G. S., \& Karlsen, S. (2017). Jeg vil bli kulturskolelærer når jeg blir stor - hva innebærer det? En undersøkelse av kvalifiseringsveier innenfor musikkfeltet [How do I become a teacher in the music and art school? An examination of the qualification routes within the field of music education]. In E. Angelo, A. Rønningen, \& R. J. Rønning (Eds.), Forskning og utvikling i kulturskolefeltet. Den doble regnbuen: IRISforsk [Research and development in the field of kulturskole. The double rainbow: IRISforsk] (pp. 157-184). Cappelen Damm Akademisk. Angermüller, J. (2015). Discourse studies. In J. D. Wright (Ed.), International encyclopedia of the social \& behavioral sciences (2nd ed., pp. 510-515). Elsevier.

Angelo, E. (2020). Musikkpedagogisk forskning - en møteplass? [Music pedagogical research-a meeting place?] In Ø. J. Eiksund, E. Angelo, \& J. Knigge (Eds.), Music technology in education-Channeling and challenging and perspectives (pp. 7-14). Cappelen Damm Akademisk.

Angelo, E., Varkøy, Ø., \& Georgii-Hemming, E. (2019). Notions of mandate, knowledge and research in Norwegian classical music performance studies. Journal for Research in Arts and Sports Education, Special Issue Community Arts / Arts Education, 3(1), 78-10o. https://jased.net/index.php/jased/article/view/1284

Askehave, I. (2007). The impact of marketization on higher education genres the international student prospectus as a case in point. Discourse Studies, 9(6), 723-742.

Bayne, S. (2006). Temptation, trash and trust: The authorship and authority of digital texts. E-Learning and Digital Media, 3(1), 16-26. https://doi.org/10.2304/ elea.2006.3.1.16 
Benedict, C., \& Schmidt, P. (2014). Educating teachers for the 21st-century challenges: The music educator as a cultural citizen. In M. Kaschub \& J. Smith (Eds.), Promising practices in 21st century music teacher education (pp. 79-99). Oxford University Press.

Borg, K. (2007). Akademisering. En väg till ökad professionalism i läraryrket? [Academisation. Increasing professionalism in the teacher vocation?]. Pedagogisk forskning i Sverige [Educational research in Sweden], 12(3), 211-225.

Bowen, G. A. (2009). Document analysis as a qualitative research method. Qualitative Research Journal, 9(2), 27-40.

Bowman, W. (2007). Who is the "we"? Rethinking professionalism in music education. Action, Criticism and Theory for Music Education, 6(4), 109-131.

Callahan, E. (2005). Cultural similarities and differences in the design of university web sites. Journal of Computer-Mediated Communication, 11(1), 239-273.

Campbell-Price, M. (2017). It depends on the priorities: the presence and profile of outdoor education on school websites. Journal of Adventure Education and Outdoor Learning, 18(3), 189-200. https://doi.org/10.1080/14729679.2017.1409642

Dean, M. (2006). Governmentality: Power and rule in modern society. Sage.

Dobrowen, L. (2020). Musikk på barnetrinnet. En studie av loereres forståelser av profesjonalitet i musikkundervisning [Music in the primary school. A study about teachers understandings of professionality in music education]. [Doctoral dissertation, The Norwegian Academy of Music]. https://nmh.brage.unit.no/ nmh-xmlui/handle/11250/2672795?locale-attribute=en

Eidsvaag, F. F., \& Angelo, E. (2021). The craftsmanship that disappeared? About the music teacher's handicraft education on a principal instrument. In E. Angelo, J. Knigge, M. Sæther, \& W. Waagen (Eds.), Higher education as context for music pedagogy research. (pp. 65-94). Cappelen Damm Akademisk.

Elliot, D. (1995). Music matters: A new philosophy of music education. Oxford University Press

Ericsson, C., \& Lindgren, M. (2011). The conditions for establishment of an ideological dilemma: Antagonistic discourses and over-determined identity in school music teaching. Discourse: Studies in the Cultural Politics of Education, 32(5), 713-728. https://doi.org/10.1080/01596306.2011.620754

Fairclough, N. (1993). Critical discourse analysis and the marketization of public discourse: The universities. Discourse \& Society, 4(2), 133-168.

Foucault, M. (1966/1989). The order of things. Routledge.

Foucault, M. (1977) What is an author? In D. F. Bouchard (Ed.), Language, countermemory, practice: Selected essays and interviews by Michel Foucault (pp. 113-138). Cornell.

Foucault, M. (1988). Technologies of the self. In L. H. Martin, H. Gutman, \& P. Hutton (Eds.), Technologies of the self: A seminar with Michel Foucault (pp. 61-49). Tavistock. 
Foucault, M. (1991). Governmentality. In G. Burchell, C. Gordon, \& P. Miller (Eds.), The Foucault effect. Studies in governmentality (pp. 85-103). University of Chicago Press.

Foucault, M. (1995/1975). Discipline and punish. The birth of the prison. Second Vintage Books Edition.

Foucault, M. (1998/1980). Power/knowledge: Selected interviews and other writings: 1972-1977. Pantheon Books.

Foucault, M. (2003/1963). The birth of the clinic: An archaeology of medical perception. Taylor \& Francis e-library.

Georgii-Hemming, E., \& Westvall, M. (2010). Music education - a personal matter? Examining the current discourses of music education in Sweden. British Journal of Music Education, 27(1), 21-33. https://doi.org/10.1017/So265051709990179

Georgii-Hemming, E., Burnard, P., \& Holgersen, S. (2013). Professional knowledge in music teacher education. Ashgate.

Hoang, T. V. Y., \& Rojas-Lizana, I. (2015). Promotional discourse in the websites of two Australian universities: A discourse analytic approach. Cogent Education, 2(1), 1011488.

Holgersen, S.-E., \& Holst, F. (Eds.) (2020). Musikfaget i undervisning og uddannelse. Status og perspektiv 2020 [Music in teaching and education. Status and perspectives 2020]. Musikpredagogiske Studier - DPU [Music Educational Studies - DPU]. https://edu.au.dk/fileadmin/edu/Udgivelser/Rapporter/ Rapport_-_Musikfaget_i_undervisning_og_uddannelse_2020.pdf

Holmberg, K. (2010). Musik- och kulturskolan i senmoderniteten: reservat eller marknad?[The community school of music and art in late modernity: Reservation or market?] [Doctoral dissertation, Malmö Academy of Music]. https://www. lu.se/lup/publication/59e988cb-3252-45bd-a936-o8fie8b6boc9

Jackson, A. Y., \& Mazzei, L. A. (2012). Thinking with theory in qualitative research. Viewing data across multiple perspectives. Routledge.

Johansen, G. (2006). Fagdidaktikk som basis- og undervisningsfag. Bidrag til et teoretisk grunnlag for studier av utdanningskvalitet [Subject didactic as basicand teaching subject. Contributions to a theoretical foundation for examining educational quality]. Nordic Research in Music Education, Yearbook 8, 115-136.

Jobbnorge (2012). Utlysningstekst. Høgskolelektor i musikk [Announcement for vacant positions, assistant professor in music]. Dronning Mauds Minne Høgskole, 22. January.

Jobbnorge (2014). Utlysningstekst. Førsteamanuensis/førstelektor i musikk [Announcement for vacant positions, associate professor in music]. Dronning Mauds Minne Høgskole, 25. February.

Jordhus-Lier, A. (2018). Institutionalising versatility, accommodating specialists. A discourse analysis of music teachers' professional identities within the Norwegian 
municipal school of music and arts [Doctoral dissertation, The Norwegian Academy of Music]. https://nmh.brage.unit.no/nmh-xmlui/handle/11250/2480686

Kaschub, M., \& Smith, J. (Eds.). (2014). Promising practices in 21st century music teacher education. Oxford University Press.

Krüger, T. (2000). Teacher practice, pedagogical discourses and the construction of knowledge: Two case studies of teachers at work [Doctoral dissertation]. Bergen University College.

Kunnskapsdepartementet [Ministry of Education and Research]. (2012). Forskrift om rammeplan for barnehageloererutdanning [Regulation on the framework plan for early childhood teacher education]. https://lovdata.no/dokument/SF/ forskrift/2012-06-04-475

Kunnskapsdepartementet [Ministry of Education and Research]. (2018). Nasjonale retningslinjer for barnehageloererutdanningen [Guidelines for early childhood teacher education]. https://www.uhr.no/_f/p1/i8dd41933-bff1-433c-a82c2110165de29d/blu-nasjonale-retningslinjer-ferdig-godkjent.pdf

Lažetić, P. (2019). Students and university websites - consumers of corporate brands or novices in the academic community? Higher Education, 77, 995-1013. https:// doi.org/10.1007/s10734-018-0315-5

Leathwood, C., \& Read, B. (2009). A feminised future? Gender and the changing face of higher education. SRHE \& Open University Press.

Lindgren, M., \& Ericsson, C. (2011). Arts education in Swedish teacher training what's at stake? Australian Journal of Teacher Education, 36(8), 18-31.

Mautner, G. (2012). The entrepreneurial university: A discursive profile of a higher education buzzword. Critical Discourse Studies, 2(2), 95-120. https://doi. org/10.1080/17405900500283540

Mills, J. (2004). Working in music: Becoming a performer-teacher. Music Education Research, 6(3), 245-261.

Nerland, M. (2003). Instrumentalundervisning som kulturell praksis: en diskursorientert studie av hovedinstrumentundervisning i høyere musikkutdanning [Instrumental teaching as cultural practice: A discourse-oriented study of instrumental teaching in higher music education]. [Doctoral dissertation]. University of Oslo.

NESH (2016). Forskningsetiske retningslinjer for samfunnsvitenskap, humaniora, juss og teologi [Guidelines for research ethics in the social sciences, humanities, law and theology]. Den nasjonale forskningsetiske komité for samfunnsfag og humaniora [The National Committee for Research Ethics in the Social Sciences and the Humanities] (NESH). https://www.etikkom.no/forskningsetiskeretningslinjer/Samfunnsvitenskap-jus-og-humaniora/

Nielsen, S. G., \& Karlsen, S. (2020). The case of Norway: A microcosm of global issues in music teacher professional development. Arts Education Policy Review. https://doi.org/10.1080/10632913.2020.1746714 
Nielsen, F. V. (2001). Musiklæreruddannelse i et integrativt relationsfelt: Indhold, struktur og opgaver [Music teacher education in an integrating field of relations: Content, structure and tasks]. Nordic Research in Music Education, Yearbook 5 , 159-176.

Nielsen, F. V. (Ed.) (2010). Musikfaget i undervisning og uddannelse. Status og perspektiv 2010 [Music in teaching and education. Status and perspectives 2010]. Musikpoedagogiske Studier - DPU. [Music Educational Studies - DPU]. https:// pure.au.dk/ws/files/32963127/Statusrapport_Musikfaget_2010.pdf

Rolle, C., Angelo, E., \& Georgii-Hemming, E. (2017). Mapping the methodological field of 'discourse analysis' in music education research. A review study part 1. In A. Cvetko \& C. Rolle (Eds.), Musikpädagogische Forschung (pp. 153-164). Waxmann.

Rose, N. (1996). Governing 'advanced' liberal democracies. In A. Barry, T. Osborne, \& N. Rose (Eds.), Foucault and political reason: Liberalism, neo-liberalism and rationality of government. UCL Press.

Saichaie, K. (2011). Representation on college and university websites: An approach using critical discourse analysis [Doctoral dissertation, University of Iowa]. https://ir.uiowa.edu/cgi/viewcontent.cgi? article $=2456 \&$ context $=$ etd

Schei, T. B. (2007). Vokal identitet: en diskursteoretisk analyse av profesjonelle sangeres identitetsdannelse [Vocal identity: a discourse theoretical analysis of professional singers identity formation] [Doctoral dissertation, University of Bergen]. http://hdl.handle.net/1956/2549

Sætre, J. H. (2014). Preparing generalist student teachers to teach music: A mixedmethods study of teacher educators and educational content in generalist teacher education music courses [Doctoral dissertation, The Norwegian Academy of Music]. https://nmh.brage.unit.no/nmh-xmlui/handle/11250/226772

Sætre, J. H. (2018) Why school music teachers teach the way they do: A search for statistical Regularities. Music Education Research, 20(5), 546-559. https://doi.org/ 0.1080/14613808.2018.1433149

Varkøy, Ø., Angelo, E., \& Rolle, C. (2020). Artist or crafts(wo)man? European Journal of Philosophy in Arts Education, 5(1), 7-32. http://www.ejpae.com/index. php/EJPAE/article/view/41

Zhang, Y., \& O'Halloran, K. L. (2013). Toward a global knowledge enterprise: University websites as portals to the ongoing marketization of higher education. Critical Discourse Studies, 10(4), 468-485. https://doi.org/10.1080/17405904.2013. 813777 



\section{About the Authors}

Elin Angelo $(\mathrm{PhD})$ is professor of music education at Norwegian University of Science and Technology (NTNU), Department of Teacher Education. Her research interests include higher music education, music teacher education, music and art school-related research and professionalism. Further information: https://www.ntnu.edu/employees/elin.angelo

Anne Haugland Balsnes (PhD) is professor of music at the University of Agder (UiA), Department of Classical Music and Music Education. Her research interests include singing in choral, educational and religious contexts and choral conductor education. Further information: https:// www.uia.no/kk/profil/annehb

Anders Dalane is associate professor of music pedagogy and music science at Nord university, Department of Teacher Education, Arts and Cultural Studies. His research interests include music performances and cultural studies, music in health context and education. Further information: https://www.nord.no/no/ansatte/anders-dalane\#\&acd=acc AboutMe\&acd=h-uprr\&acd=h-upor

Fritz Flåmo Eidsvaag is assistant professor of music education at Norwegian University of Science and Technology (NTNU), Department of Teacher Education. His research interests include higher music education and generalist teacher education, as well as artistic research. Further information: https://innsida.ntnu.no/person/eidsvaag

David Scott Hamnes (PhD) is associate professor at Norwegian University of Science and Technology (NTNU), Department of Music, senior advisor in church music to Norway's Church Council, organ teacher at 
Trondheim municipal music and art school, and director of music at Ilen parish church, Trondheim. His research interests include reception and historical studies in hymnology, die neue Sachlichkeit and musicology, and music education. Further information: https://www.ntnu.no/ansatte/ david.scott.hamnes

Anne-Lise Heide is associate professor of music at Norwegian University of Science and Technology (NTNU), Department of Teacher Education. Her research interests include interdisciplinarity and aesthetic learning processes in teacher education. Further information: https://innsida. ntnu.no/user/annelhei/ansatt/min-profil

Sunniva Skjøstad Hovde $(\mathrm{PhD})$ is associate professor of music at Queen Maud University College of Early Childhood Education (DMMH). Her research interests include music and arts education, marginalization and music, post-qualitative and arts based methodologies, and traditional music in a global context. Further information: https://dmmh.no/ om-dmmh/ansatte/sunniva-skjostad-hovde

Dag Jansson $(\mathrm{PhD})$ is associate professor of arts management at Oslo Metropolitan University (OsloMet) and choral conducting at the Academy of Music and Drama, Gothenburg. His research interests include aesthetic leadership, choral conductor competences, and arts education. Further information: https://www.routledge.com/authors/i17670-dag-jansson

Runa Hestad Jenssen is a performer within the vocal field, and assistant professor in Music at Nord University, Faculty of Education and Arts. Her research concerns music education, singing, gender, performativity, embodiment and the sociocultural aspects of singing. Currently she is working on a PhD study on female voice change. Further information: https://www.nord.no/no/ansatte/runa-hestad-jenssen

Carina Borgström Källén (PhD) is an associate professor of music education at the University of Gothenburg, department Academy of Music and Drama. Her research interests include gender perspectives 
on music education, preparatory music education and higher music education. Further information: https://www.gu.se/en/about/find-staff/ c7f6f184-d3ba-41a8-9646-5b198o25ed 31

Jens Knigge (Dr. phil) is professor of music education at Nord University, Faculty of Education and Arts, Campus Levanger. He is a board member of the German Association for Research in Music Education (AMPF) and co-editor of the Bulletin of Empirical Music Education Research (b:em). His research interests include music teacher education, musical competency development, and psychological aspects of musical teaching and learning. Further information: http://jensknigge.info

Monica Lindgren $(\mathrm{PhD})$ is professor in music education at the Academy of Music and Drama, University of Gothenburg, Sweden. Her research interest is directed towards aesthetic/artistic learning in relation to issues of power, identity and inclusion in various types of educational contexts. Further information: https://www.gu.se/om-universitetet/hitta-person/ monicalindgren

Robin Rolfhamre $(\mathrm{PhD})$ is professor of music pedagogy at the University of Agder (UiA), Department of Classical Music and Music Education. His research is rooted in music pedagogy, early music performance studies, and organology. As a performer, he has released several full albums and has performed concerts worldwide. Further information: www.rolfhamre.com

Ragnhild Sandberg-Jurström $(\mathrm{PhD})$ is senior lecturer in music education at Ingesund School of Music, Department for Artistic Studies, Karlstad University, Sweden. Her research interests include conditions for musical learning and development, and formative and summative feedback/assessment in music teacher education. Further information: https://www.kau.se/forskare/ragnhild-sandberg-jurstrom

Morten Sæther is professor (docent) of music education at Queen Mauds University College of Early Childhood Education. (DMMH). His research interests include music in early childhood education, children's 
musical development and preschool teacher professionalism. Further information: https:/dmmh.no/om-dmmh/ansatte/morten-sather

Jan Ketil Torgersen is assistant professor in music at Queen Maud University College of Early Childhood Education (DMMH). His research is focused on childrens interaction with information technology, music activities in kindergarten and childrens culture as a part in modern society. Further information: https://dmmh.no/om-dmmh/ansatte/jan-ketil-torgersen

Ben Toscher is in his final year as a PhD student as part of SFU Engage, a research center dedicated to engaged education through entrepreneurship, at the Norwegian University of Science and Technology (NTNU), Institute for Industrial Economy and Technology Management. His published research examines entrepreneurship education in music and arts education, entrepreneurial learning, and experiential learning pedagogy. Further information: https://bit.ly/347wDmj

Roy A. Waade (PhD) is associate professor at Nord University, Norway. The main focus in his work as a music teacher educator, musician and researcher, is improvisation, "instant composing" and school-concerts. Further information: https://www.nord.no/no/ansatte/roy-aksel-waade\# \&acd=h-uprr\&acd=h-upor\&orpi $=1 \&$ orpi $=2$

Wenche Waagen is associate professor in music education at Norwegian University of Science and Technology (NTNU), Department of Music. Her research interest is directed towards music- and art schools, the knowledge base of instrumental teachers and assessment in performing music. Further information: https://innsida.ntnu.no/person/wenchw

Olle Zandén (PhD) is associate professor in music education and head of the pedagogical unit at the Academy of Music and Drama, University of Gothenburg, Sweden. His research interests are focused on the music classroom, especially with regard to evaluative and communicative aspects of music teaching and learning. Further information: https://www.gu.se/ om-universitetet/hitta-person/adae3051-166f-40d3-8271-565ecbef25c8 


\section{Review Panel}

- Hilde Synnøve Blix (PhD), Professor of Music Education, UiT The Arctic University of Norway.

- Catharina Christophersen (PhD), Professor of Music Education, Western Norway University of Applied Sciences.

- Lorents Edberg (PhD), Associate Professor of Music Education, Umeå University.

- Øivind Johan Eiksund (PhD), Associate Professor of Music, Norwegian University of Science and Technology.

- Stefan Gies (Dr. phil.) AEC (Association Européenne des Conservatoires, Académies de Musique et Musikhochschulen) CEO, Brussels.

- Marja Heimonen (DMus), University Lecturer in Music Education, Sibelius Academy, UniArts Helsinki.

- Linn Hentschel (PhD), Associate Professor of Music Education, Umeå University.

- Juliet Hess (PhD), Assistant Professor of Music Education, Michigan State University, College of Music.

- Sven-Erik Holgersen (PhD), Associate Professor Emeritus of Music Education, Aarhus University.

- Karin Johansson (PhD), Professor of Artistic Research in Music, Malmö Academy of Music, Lund University.

- Sidsel Karlsen (PhD), Professor of Music Education, The Norwegian Academy of Music.

- Camilla Kvaal (PhD), Associate Professor of Music Education, Inland Norway University of Applied Sciences.

- Anna-Karin Kuuse (PhD), Lecturer in Music and Drama, University of Gothenburg.

- Anne Jordhus-Lier (PhD), Associate Professor of Music Education, Inland Norway University of Applied Sciences. 
- Siw Graabræk Nielsen (PhD), Professor of Music Education, Norwegian Academy of Music.

- Ingvild Olsen Olaussen (PhD), Associate Professor of Drama and Theater, Queen Mauds University College of Early Childhood Education.

- Silje Valde Onsrud (PhD), Associate Professor of Music Education, Western Norway University of Applied Science.

- Christian Rolle (PhD), Professor of Music Education, University of Cologne.

- Anders Rønningen (PhD), Associate Professor of Music Education, University of South-Eastern Norway.

- Sigrid Røyseng (PhD), Professor of Cultural Sociology, Norwegian Academy of Music.

- Tami Spry, (PhD), Professor of Communication and Performance Studies, St. Cloud State University.

- Regine Vesterlid Strøm (PhD), Associate Professor of Music Education, Nord University.

- Gaja von Sychowski (PhD), Professor of Education, Musikhochschule Lübeck.

- John Vinge (PhD), Associate Professor of Music Education, Norwegian Academy of Music.

- Olle Zandén (PhD), Associate Professor of Music Education, University of Gothenburg. 